\title{
FISIOGRAFIA, SOLOS E SUAS RELAÇÕES EM TRÊS \\ COLINAS DA SERRA "CORDILLERITA", PARAGUAI
}

\author{
SERGIO MAURINO BURGOS SOSA \\ Engenheiro Agrônomo
}

Orientador: Prof. Dr. JOÃO BERTOLDO DE OLIVEIRA

Tese apresentada à Escola Superior de Agricultura "Luiz de Queiroz", Universidade de São Paulo, para obtenção do título de Doutor em Agronomia, Área de Concentração:

Solos e Nutrição de Plantas

PIRACICABA

Estado de São Paulo - Brasil

Janeiro - 1998 
Dados Internacionais de Catalogação na Publicação (CIP) DIVISĀO DE BIBLIOTECA E DOCUMENTAÇĀO - Campus "Luiz de Queiroz"/USP

Burgos Sosa, Sergio Maurino

Fisiografia, solos e suas relaçōes em três colinas da Serra de "Cordillerita", Paraguai / Sergio Maurino Burgos Sosa. - - Piracicaba, 1998.

142 p. : il.

Tese (doutorado) - Escola Superior de Agricultura Luiz de Queiroz, 1998.

Bibliografia.

1. Colina 2. Geografia fisica 3. Geomorfologia 4. Paraguai 5. Pedologia 6. Serra 7. Solo I. Título

CDD 631.4 


\section{FISIOGRAFIA, SOLOS E SUAS RELAÇŌES EM TRÊS COLINAS DA SERRA "CORDILLERITA", PARAGUAI}

\section{SERGIO MAURINO BURGOS SOSA}

Aprovada em 23.03.1998

Comissão julgadora:

Prof. Dr. João Bertoldo de Oliveira

Prof. Dr. Carlos Roberto Espíndola

Prof. Dr. Arary Marconi

Prof. Dr. José Marques Junior

Prof. Dr. Celso Augusto Clemente
UNICAMP

UNICAMP

ESALQ/USP

FCAV/UNESP

ESALQ/USP

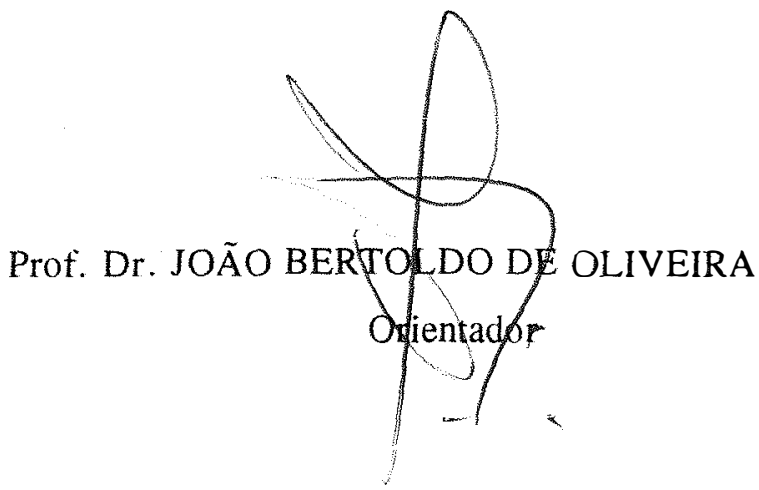


À memória de minha mãe

Dona Cipriana Sosa,

DEDICO. 


\section{AGRADECIMENTOS}

A Deus, pela força dada através do Espírito Santo.

À minha esposa Mirtha, pelo Amor e constante apoio e às minhas filhas Silvia, Romina e Sandra pela compreensão.

À FAPESP, pela importante ajuda fïnanceira para a fïnalização da tese.

À G.T.Z. pela importante ajuda financeira.

Ao Departamento de Ciência do Solo da Escola Superior de Agricultura "Luiz de Queiroz", da Universidade de São Paulo, pela oportunidade de realizar esta Pós-Graduação e pelas análises laboratoriais.

Ao Geólogo Prof. Darío Gómez, pelo constante apoio científico.

Ao Eng ${ }^{\mathrm{o}} \mathrm{Agr}^{\mathrm{O}}$ Hugo Huespa Fatecha pela ajuda inicial.

Ao Prof. Eng ${ }^{\circ} \mathrm{Agr}^{\circ}$ Pedro Gonzales, Decano da Faculdade de Ciências Agrárias do Paraguai, pela permissão para o afastamento do serviço, de 4 anos,

Aos $\mathrm{Eng}^{\mathrm{o}} \mathrm{S}_{\mathrm{Agr}^{\circ}}^{\mathrm{o}} \mathrm{S}$ Profs. Drs. João Bertoldo de Oliveira e Igo F. Lepsch, pelas sábias orientações.

Aos Profs. Drs. Selma de Castro, José L.I. Demattê e Jairo Jimenez Rueda, pelas construtivas discussões.

Ao Geólogo Prof. Agustin Lopez Nunez pelo empréstimo das fotos aéreas. 
Aos colegas da Carreira de Engenharia Florestal da Faculdade de Ciências Agrárias, Universidade Nacional de Asunción, pelo constante estímulo.

Aos guarda-parques do Monumento Nacional "Ybycu'i", Paraguai, Raul Alonso, Solano Gonzalez e demais colaboradores pela ajuda em momentos difíceis.

Aos produtores rurais da Serra da "Cordillerita" pelo interesse mostrado e ajuda durante o trabalho de campo.

À Bete, Vladimir e Luciano, pela importante ajuda na execução das análises de laboratório.

Aos vizinhos da Rua do Trabalho do Bairro Independência, Piracicaba, pela amizade e importante ajuda espiritual.

Ao Eng $^{\circ} \mathrm{Agr}^{\circ}$ Dr. Julio Gonzalez pela amizade e apoio moral.

Aos Professores e Técnicos do Departamento de Geociências da UNESP de Rio Claro, Profs. Drs. José A. Nardi, Zanardo, Júnior e Vladimir, pela execução das análises de fluorescência de raio $\mathrm{X}$.

À minha filha Silvia, pelos desenhos finais.

À Clotilde Maria Batochio Cunha pela amizade e paciência na fase final da tese. 


\section{SUMÁRIO}

LISTA DE TABELAS ....................................................... viii

LISTA DE FIGURAS ......................................................... ix

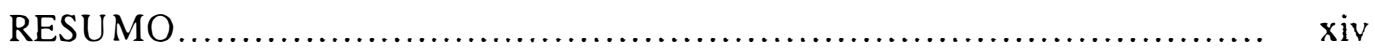

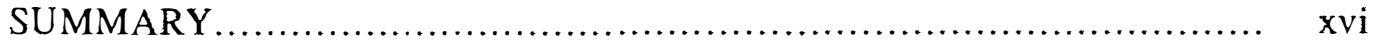

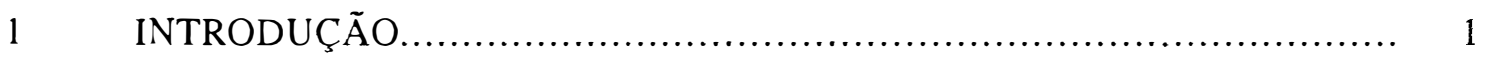

2 REVISÃO DE LITERATURA................................................ 3

$2.1 \quad$ Geologia e evolução do relevo........................................................ 3

2.2 Gênese e desenvolvimento do solo............................................. 8

$2.3 \quad$ Modelos do solo-paisagem.................................................... 13

2.4 Unidades de solos............................................................. 17

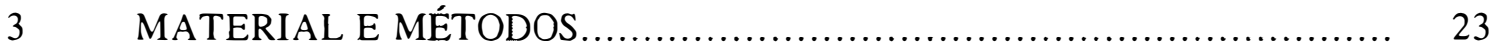

3.1 Caracterização da área de estudo............................................. 23

3.1.1 Localização......................................................................... 23

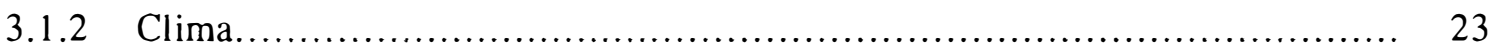

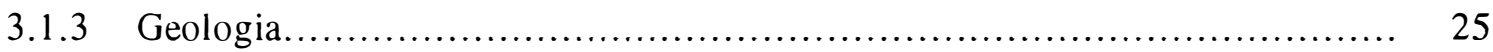

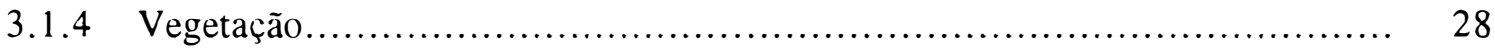

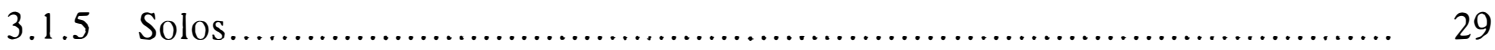

3.1.6 Hidrologia................................................................. 30

3.1.7 Usos da terra............................................................... 30

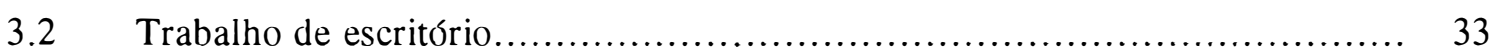

3.2.1 Mapeamento das unidades fisiográficas ...................................... 33

3.2.2 Análises das informações........................................................ 35

$3.3 \quad$ Trabalho a campo............................................................ 37

3.4 Análises de laboratório .......................................................... 39 
$4 \quad$ RESULTADOS E DISCUSSÃO .......................................... 41

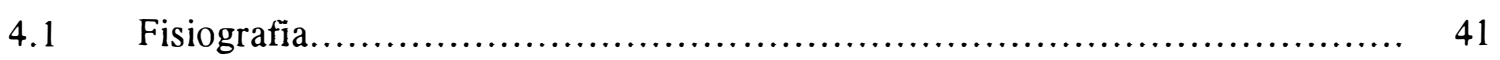

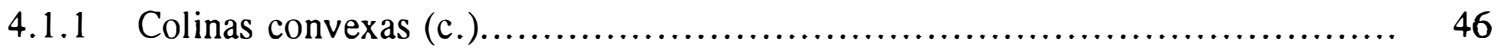

4.1.2 Colinas convexo-côncavas (c-c.)........................................ 49

4.1.3 Colinas convexo-côncavo-convexas (c-c-c.) ................................. 51

4.1.4 Colinas escalonas (c.e.)............................................... 54

4.1.5 Morros testemunhos (m.t.).............................................. 56

4.1.6 Encostas convexo-côncavas de frente de falhas (e.c-c.)....................... 58

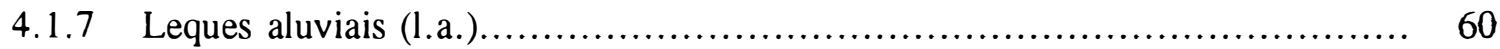

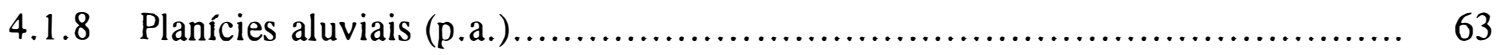

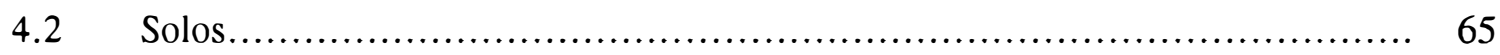

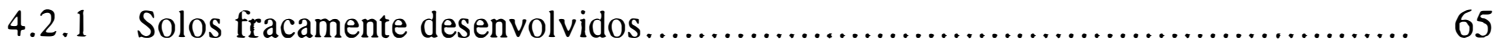

4.2.2 Solos moderadamente desenvolvidos................................... 72

4.2.3 Solos bem desenvolvidos............................................... 80

4.2.4 Solos fortemente desenvolvidos........................................... 87

4.3 Toposeqüências de solos........................................... 94

4.3 .1 Toposeqüência convexa................................................ 94

4.3.2 Toposeqüência convexo-linear....................................... 97

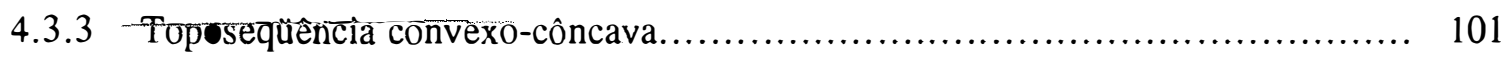

4.3.4 Toposeqüência convexo-côncavo-convexa................................. 104

4.4 Relaçōes solo-material de origem....................................... 108

4.4.1 Possíveis materiais de origem.......................................... 109

4.4.2 Atributos dos solos herdados do material de origem........................ 115

4.5 Relações solo-relevo..................................................... 119

5 CONCLUSÕES........................................................ 127

REFERÊNCIAS BIBLIOGRÁFICAS.................................... 128

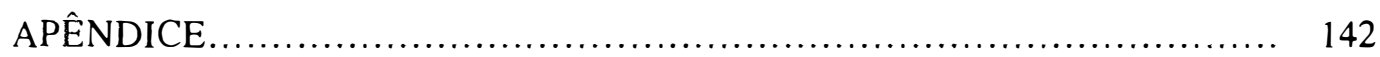




\section{LISTA DE TABELAS}

Página

Tabela 1 - Precipitação pluvial, temperatura e balanço hídrico, médias mensais da Estação Meteorológica de Villarrica, situada a $50 \mathrm{~km}$ ao Leste da Serra de "Cordillerita"

Tabela 2 - Resumo dos atributos micromorfológicos do solos fracamente desenvolvidos

Tabela 3 - Resumo dos atributos micromorfológicos do solos moderadamente desenvolvidos

Tabela 4 - Resumo dos atributos micromorfológicos dos solos bem desenvolvidos....

Tabela 5 - Resumo dos atributos micromorfológicos dos solos fortemente desenvolvidos

Tabela 6 - Composição mineralógica da areia fina das principais formações geológicas obtida por microscopia convencional

Tabela 7 - Minerais da fração areia fina de alguns solos das três colinas estudadas...

Tabela 8 - Relação entre alguns atributos dos solos e o relevo. T: topo; Ts: terço superior; Tm: terço médio; Ti: terço inferior; Qc: quebra convexa; C: concavidade; Es: encosta inferior; Em: Encosta média; Ei: encosta inferior 


\section{LISTA DE FIGURAS}

\section{Página}

Figura 1 - Alguns modelos de evolução do relevo: a) redução da pendente, b) reposição da pendente, c) equilíbrio dinâmico, d) recuo diferencial, e) recuo paralelo com escarpa e f) recuo paralelo sem escarpa.........

Figura 2 - Evolução do relevo ao longo do tempo com alternância de climas: a) do seco para o úmido e b) do úmido para o seco.

Figura 3 - Modelo bidimensional de nove unidades geomórficas de solo-relevo de uma catena hipotética proposto por Dalrymple et al. (1968)........

Figura 4 - $\quad$ Localização da Serra de "Cordillerita" no Paraguai, isoietas (----) e isotermas (--) médias anuais do período 1961-1990 (Instituto, 1985).

Figura 5 - Coluna estratigráfica da área de estudo, modificado de Paraguay (1986).

Figura 6 - Mapa geológico da área de "Cordillerita" (The Anschutz Corporation, 1981)...................................................

Figura 7 - Mapa de solos da região da Serra "Cordillerita" (Lopez et al., 1995).

Figura 8 - $\quad$ Rede de drenagem na Serra de "Cordillerita", caminhos e povoados principais

Figura 9 - Imagem composta em falsa cor do satélite Landsat TM, bandas 3, 4 e 5, do dia 23.09.94 da Serra "Cordillerita". (Cores de tonalidade verde escura: mata nativa; verde clara: pastagem seca; roxo: pastagem úmida; vermelho: solo úmido; lilás: terra alagada).......... 
Figura 10 - Principais unidades fisiográficas da Serra "Cordillerita" delimitadas com base na interpretação de fotos aéreas pancromáticas em escala 1:50.000 do ano de 1965 e posição dos três perfís topográficos (AB, B-C, D-E, E-F, G-H E H-I). T: Topo; E: escarpa; V: vertente; $\mathrm{P}$ : patamar; S: sopé $\mathrm{Pl}$ : planície

Figura 11 - Perfís topográficos com direção predominante Oeste-Leste da Serra dê "Cordillerita". Setor Noroeste da Serra (a); setor central (b e c); setor sul (d). Linhas tracejadas indicam falhamentos e fraturas. (Escala horizontal 1:100.000; Escala vertical 1:20.000, $S=5$ ). Fonte: Cartas topográficas da D.S.G.M. 1: Colinas convexas; 2: Colinas convexo-côncavas; 3 : Colinas convexo-côncavo-convexas; 4 : Colinas escalonadas; 5: Morros testemu-nhos; 6: Encostas convexocôncavas de frente de falhas; 7: Leques aluviais; 8: Planícies aluviais

Figura 12 - Processos geomórficos observados na maioria das colinas da serra: a) sulcos de erosão; b) árvores inclindas com relaçao à vertical por causa do rastejamento

Figura 13 - Paisagem típica das colinas convexas (a); e perfil topográfico representativo com relaçâo de escalas $S=5$ (b)

Figura 14 - Paisagem do terço medio das colinas convexo-côncavas (a) e perfil topográfico representativo da Colina de "Mbokaja puku" com relação de escalas $S=4$ (b) .....................................

Figura 15 - Paisagem das colinas convexo-côncavo-convexas (a) e perfil representativo com relação de escalas $S=4$ (b)

Figura 16 - Paisagem característica das colinas escalonadas (em $2^{\circ}$ plano) (a) e perfil topográfico com relação de escalas $S=4$ (b)........... 
Figura 17 - $\quad$ Paisagem do Morro "Sao Jose" (a) e perfil topográfico (b)............

Figura 18 - Paisagem das colinas convexo-côncavas de frente de falha (a) e perfil topográfico, com relação de escalas $S=2$ (b) .................. 59

Figura 19 - Paisagem do leque aluvial (a) e perfil topográfico com uma relaçào

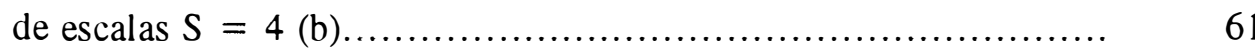

Figura 20 - Paisagem da planície aluvial do Arroio "Ybycu'i" no extremo sul da serra, em "La Rosada" (em primeiro plano) (a) e perfil topográfico com direção Oeste-Leste e razão de escalas $S=4$ (b) natural.........

Figura 21 - Fotomicrografias dos solos fracamente desenvolvidos: a) nódulo ferruginoso do horizonte $11 \mathrm{~A}(\mathrm{ln})$; b) nódulo ferruginoso na camada 11C $(\ln ) ; c)$ microfratura preenchida com ferro na camada $11 \mathrm{Cr}(\ln )$; d) poro orto-cavitário de um nódulo do horizonte $11 \mathrm{~A}(\mathrm{nc})$; e) estrutura de base guefú-rica na camada 11C (ln); f) estrutura do

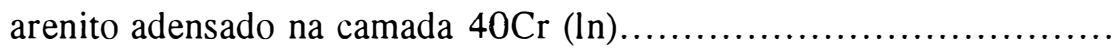

Figura 22 - Difratogramas dos raios $X$ da fração argila dos solos fracamente desenvolvidos: a) horizonte $11 \mathrm{C}$; b) Horizonte $11 \mathrm{Cr}$. C = caulinita; $M=\operatorname{mica}(\mathrm{f})$.

Figura 23 - Fotomicrografias dos solos moderamente desenvolvidos: a) nódulos ferruginosos da camada $35 \mathrm{Cc}(\mathrm{ln})$; b) zona de contato entre as camadas $35 \mathrm{Cc}$ e $35 \mathrm{Cr}(\mathrm{ln})$; c) separações plásmicas esquelssépicas do horizonte 12Bi (nc); d) fundo matricial da camada $12 \mathrm{~F}(\mathrm{nc})$; e) poro ortocavitário do horizonte $32 \mathrm{Cc}(\mathrm{nc})$; f) poro com goetita

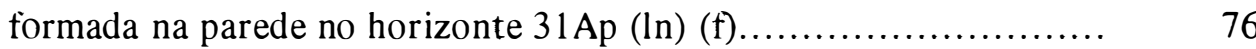

Figura 24 - Difratogramas dos raios $X$ da fração argila dos solos moderadamente desenvolvidos: a) horizonte $31 \mathrm{Bt}$; b) camada $31 \mathrm{Cc}$ álico............. 
Figura 25 - Fotomicrografias dos solos bem desenvolvidos: a) fundo matricial do horizonte $41 \mathrm{E}(\mathrm{ln})$; b) poro ortocavitário no $41 \mathrm{E} / \mathrm{B}(\mathrm{nc})$; c) microagregados e nódulo do $21 \mathrm{Bt}(\mathrm{ln})$; d) microagregados adensados com plasma bimassépica do $22 \mathrm{Bt} 2$ (nc); e) nódulos ferruginosos e microporos goetitizando na camada $44 \mathrm{Cc}(\ln ) ; \mathrm{f})$ plasma despigmentando

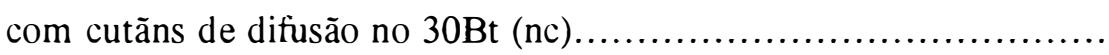

Figura 26 - Difratogramas dos raios $X$ da fração argila dos solos bem desenvolvidos: a) Horizonte $30 \mathrm{Bt}$; b) horizonte $30 \mathrm{Cr}$. C: caulinita; $\mathrm{M}$ : mica; V: vermiculita..............................

Figura 27 - Fotomicrografias dos solos fortemente desenvolvidos: a) poros ortocavitários do horizonte $13 \mathrm{Bw}(\mathrm{nc})$; b) reliquia de nódulo do horizonte 13 Bwf (ln); c) microagregados do horizonte 13 Bwf (ln); d) poro ortocavitário dentro de uma plintita, com goetita nas paredes, horizonte $13 \mathrm{Bwf}(\mathrm{nc})$; e) plasma esquelssépica horizonte $42 \mathrm{~A} 3$ (nc); f) microagregados no horizonte $42 \mathrm{Bw}(\mathrm{ln})(\mathrm{b}) \ldots \ldots \ldots \ldots$

Figura 28 - Difratogramas do raio-X da argila dos solos fortemente desenvolvidos: a) Horizonte $42 \mathrm{AB}$; b) Horizonte 42 Bw. C: caulinita; $\mathrm{M}$ : mica; V: vermiculita.

Figura 29 - Distribuição dos solos nas diferentes posições da toposequêencia convexa. P: podzólico; Re: regossolo; V: vermelho amarelo; a: álico....

Figura 30 - Distribuição em profundidade da argila (a), do C orgânico (b) da areia fïna (c) e da relação $\mathrm{Ti} / \mathrm{Zr}$ (d) nos solos da toposequência convexa.

Figura 31 - Distribuição dos solos na toposequência linear convexo-linear com orientação Oeste da colina convexa. Re: Regossolo; $\mathrm{Cb}$ : Cambissolo; L: Latossolo; p: plíntico; V: vermelho-amarelo 
Figura 32 - Distribuição em profundidade da argila (a); do C orgânico (b); da areia fina (c) e da relação $\mathrm{Ti} / \mathrm{Zr}$ nos solos da toposeqüência linear de uma colina convexa.

Figura 33 - Distribuição dos perfís de solos na toposeqüência convexo-côncava de "Mbokaja puku". $\mathrm{Re}=$ Regossolo, $\mathrm{Cb}=$ Cambissolo; $\mathrm{P}=$ Podzólico; V = vermelho-amarelo; $\mathrm{a}=$ álico; $\mathbf{d}=$ distrófico.........

Figura 34 - Distribuição em profundidade da argila (a), do C orgânico (b), da areia fina (c) e da relação $\mathrm{Ti} / \mathrm{Zr}$ da toposeqüência convexo-côncava com orientação Leste e localizada em "Mbokaja puku"

Figura 35 - Distribuição dos solos em diferentes posições da toposeqüência convexo-côncavo-convexa. Re: Regossolo; SL: Solos litólicos; Cb: Cambissolo; P: Podzólico; L: Latossolo; V: vermelho-amarelo; á = álico.

Figura 36 - Distribuição em profundidade da argila (a), do C orgânico (b), da areia fina (c) e da relação $\mathrm{Ti} / \mathrm{Zr}$ nos solos da toposequência convexacôncavo-convexa...............................................

Figura 37 - Fotografias do limite solo/possível material de origem subjacente: a) Podzólico Vermelho Amarelo; b) Latossolo Vermelho amarelo

Figura 38 - Distribuição do tamanho das areias das três formações geológicas do Grupo "Ca'acupe"

Figura 39 - Fotomicrografia das características do arenito "Cerro Hũ": grãos estratificados do horizonte $12 \mathrm{~F}$ (a); grãos mal selecionados e biotita no horizonte $13 \mathrm{~F} \mathrm{~b}$ )

Figura 40 - Foto do arenito arcosiano (Formação "Cerro Hũ”)

Figura 41 - Esquema da relação solo-relevo em três colinas com diferentes formas superficiais na Serra da "Cordillerita" 


\title{
FISIOGRAFIA, SOLOS E SUAS RELAÇÕES EM TRÊS COLINAS DA SERRA "CORDILLERITA", PARAGUAI
}

\author{
Autor: SERGIO MAURINO BURGOS SOSA
}

\author{
Orientador: Prof. Dr. JOÃO BERTOLDO DE OLIVEIRA
}

\section{RESUMO}

Este trabalho de investigação tem como objetivo principal encontrar as relaçōes que possam existir entre a fisiografia e os solos da Serra de "Cordillerita", Paraguai, para a qual se realizou um mapeamento das principais unidades fisiográficas, com base na interpretação de fotos aéreas pancromáticas em escala 1:75.000 do ano de 1994 e viagens de reconhecimento de campo.

Das oito unidades fisiográficas delimitadas foram escolhidas três colinas com diferentes formas do perfil topográfico: colinas convexas; colinas convexo-côncavas e colinas convexo-côncavo-convexas, onde foram descritos 15 solos distribuídos em 4 toposeqüências com diferentes orientações e localizados nos principais segmentos do relevo identificáveis na fotointerpretação. Coletaram-se dos horizontes de solos amostras deformadas e indeformadas para serem efetuadas as seguintes análises: análises micromorfologicas em lâminas delgadas, análises físicas e químicas, análises mineralógicas em aparelho de raios-X e fluorescência do raio-X.

Todos os solos estudados originaram-se a partir do arenito arcosiano "Cerro hu" do Grupo "Ca'acupe" depositado por um processo transgressivo do mar no período Ordoviciano/Siluriano, do qual foram herdadas algumas características importantes como a textura e a mineralogia da fração argila, sendo os principais minerais primários o quartzo, o feldspato e a mica os precursores dos minerais 
secundários identificados nos solos, principalmente caulinita, vermiculita e mica em ordem decrescente, dependendo da posição topográfica e da unidade fisiográfica estudada. Outras rochas contendo minerais ricos em ferro em suas estruturas, mas hoje ausentes na área de estudo, contribuíram indiretamente na gênese do horizonte petroplíntico presente na maioria dos solos estudados.

O relevo da Serra de "Cordillerita" originou-se por processos tectônicos e evoluiu sob a influência de processos geomórficos (erosão, rastejamento, desmoronamento) relacionados a um clima quente e úmido, dado que as colinas encontram-se escalonadas e têm formas predominantemente convexas.

A gênese dos solos está relacionada diretamente com a posição topográfica e com a forma do relevo, encontrando-se os solos mais desenvolvidos nas posições mais estáveis da paisagem e tendo alguns atributos dos solos variado em função das formas topográficas.

Solos fracamente desenvolvidos ocupam as cimeiras das diferentes colinas, principalmente regossolos pouco profundos, enquanto que solos moderadamente desenvolvidos, como os Cambissolos estão relacionados as quebras convexas do relevo e ocorrência de horizontes petroplínticos formados por influência do lençol freático temporário a nível do limite entre o solum e a alterita. Os solos melhor desenvolvidos como os podzólicos e latossolos ocupam posições mais estáveis das vertentes principalmente os topos mais largos e os declives suaves a moderados das encostas e dos sopés.

Os principais processos geomórficos observados são: erosão, transporte e sedimentação de materiais de solos e de soluções, movimentos de massas lentos (rastejamento) e rápidos (desmoronamento) e fluxo lateral da água subsuperfícial, os quais interagem com os processos pedogenéticos de acúmulo e humificação da matéria orgânica, translocação de argilominerais, intemperismo dos minerais primários, reorganização do plasma, síntese de minerais secundários, ferrólisis e transformações dos minerais de ferro. 


\title{
FISIOGRAPHY, SOIL AND THEIR RELATIONSHIPS ON THREE HILLSLOPES FROM THE “CORDILLERITA" HILLS, PARAGUAY
}

\author{
Author: SERGIO MAURINO BURGOS SOSA \\ Adviser: Prof. Dr. JOÃO BERTOLDO DE OLIVEIRA
}

\section{SUMMARY}

This research has the main objective to find any relationships between the fisiography and the soils of the "Cordillerita" hills from Paraguay, starting with the mapping of the fisiographic units based on the interpretation of airphotos in the scale of $1: 75.000$ and on recognaissance survey.

From the eight fisographic units, three hills were choosen according to their topographic forms: convex, concave-convex and convex-concave-convex hills, where fifteen soil profiles were described on different relief position, which were destributed in four hillslopes with different orientation and in the way they could be identified with the airphotointerpretation, taking deformed and undeformed samples from each soil horizon in order to realize the following analysis: thin section micromorphology, physico-chemical analysis, mineralogical analysis in X-ray difractometer and X-ray fluorescence.

All the studied soil derive from the arcosian sandstone, the "Cerro hû" formation of the "Ca'acupe" group, which it was deposited by ocean transgretion ocurred during the Ordovicic/Silurian period, from which some characteristics were inherited such as soil texture and clay mineralogy, by this way primary minerals mainly feldespars and mica were transformed in kaolin, and vermiculite in decressing order of quantity, depending of the topographic position and the hillslope estudied. 
Other rocks with ferrous rich composition, today absent on this area, may contributed indirectly to the petroplintic horizon formation, which is a soil common horizon in many toposequences.

The "Cordillerita" relief was originated by tectonic forces, but the actual configuration is the result of geomorfic processes (erosion, creeping and mass folling) related to humid and worm climate, becouse the hills are scaled and their shapes are predominantly convex.

Soil genesis and evolution are directly related to relief aspect and shape, so the more developed soils are on the more stable position and many soil atributes changed with the topographic shape.

The weak developed thin regosols are found on the hill tops but the moderated developed cambisols are related to the convex inflections where petroplintic horizons occurs dueing to temporary water table fluctuation between the soil and rock limits meanwhile better developed podzolic and latosols ocupied extensive tops and the more estable landscape positions such as gentle and moderately slopes and toeslopes.

The main geomorphic process founded are: erosion, transportation and deposition of soils materials and solutions, slow land movements like creeping and fast ones like land and rocks falling and subsurface water table movements, interacts with pedogenetic process including organic matter acumulation and humification, plasmic reorganization, clay translocation, rock minerals degradation, soil clay synthesis, ferrolysis, and ferrous transformation. 


\section{INTRODUÇÃO}

O planejamento adequado das atividades destinadas a promover um desenvolvimento sustentável do território deveria estar baseado no conhecimento de todos os processos que participam na evolução da superfície terrestre, principalmente os que modelam o relevo, originam diferentes tipos de sedimentos e de solos, mostram velhas superfícies e controlam o fluxo de energia e da água entre os diferentes componentes do sistema ambiental.

Quase todos os problemas relacionados com a disponibilidade e qualidade dos alimentos e das águas, o destino dos resíduos antrópicos, a recuperação das terras degradadas, o impacto do aquecimento global nos ecossistemas terrestres e a qualidade ambiental, tem a ver com a dinâmica da paisagem e dos solos, onde os estudos das relações solo-paisagem podem contribuir enormemente para resolver tais problemas.

Atualmente existe no Paraguai o grande desafio de utilizar os recursos naturais sem degradar o ambiente, dado que muitas atividades de desenvolvimento realizadas nas últimas décadas contribuiram negativamente com a degradação ambiental, ocasionando perdas irreversíveis dos mesmos, e muitas outras ainda devem ser implementadas no futuro imediato para satisfazer a crescente necessidade dos seus habitantes.

A degradação dos solos com topografia acidentada constitui um dos principais problemas da Zona Central do Paraguai, a qual é ocasionada por uma forte pressão antrópica sobre a terra, resultando em graves impactos ambientais e sócioeconômicos negativos por ter-se pouco conhecimento dos solos e dos processos dinâmicos da paisagem. 
A Serra de "Cordillerita" foi escolhida para realizar esta pesquisa, por constituir conjuntamente com a Serra dos Altos aproximadamente $25 \%$ da Zona Central do Paraguai, caracterizada por uma topografia acidentada, relativamente pouca alteração ambiental e atividades econômicas baseadas principalmente na produção agrícola, pecuária e florestal.

O objetivo desta investigação é obter informações sobre a fisiografia, os solos e suas relações na Serra de "Cordillerita", como subsídio aos levantamentos de solos a serem executados, cujas metodologias e precisão dependem fundamentalmente do conhecimento das relações solo-paisagem.

Para a consecução deste propósito idealizaram-se as seguintes hipóteses:

a) Alguns atributos dos solos poderiam ajudar na identificação do material de origem.

b) A maioria dos solos da serra seriam filiados ao arenito arcosiano da Formação "Cerro Hũu", pertencente ao Grupo "Ca'acupé".

c) Outros materiais litológicos provenientes de outras formações geológicas (Formação "Sapukái", "Tobatî", "Kari'y") teriam participado indiretamente na gênese de alguns solos da serra.

d) O relevo atual da serra teria uma origem tectônica.

e) Processos geomórficos e pedogenéticos relacionados a um paleoclima predominantemente quente e úmido teriam influenciado na configuração atual do relevo.

f) A distribuição espacial dos atributos dos solos estaria diretamente relacionada com a forma do relevo e com a posição topográfica dos mesmos. 


\section{REVISÃO DE LITERATURA}

\subsection{Geomorfologia e evolução do relevo}

Derruau (1966) definiu a geomorfologia como parte das Ciências Fisiográficas que estuda as formas do relevo terrestre, a qual tem como objetivo a descrição das formas do relevo por um lado, e por outro, a explicação de como evoluiu e quais processos intervieram na sua modelagem, classificando as "formações superficiais" em depósitos (eólicos, aluviais, etc), regolitas (do grego regnumi = romper, que constitui o manto de detritos resultantes da fragmentação das rochas subjacentes) e solos (definido como a alteração superficial da rocha ou da regolita sob a ação dos agentes químicos, físicos e biológicos, produzindo partículas finas capazes de trocar íons nutritivos para as plantas). Segundo o mesmo autor, a gênese das formas do relevo é complexa devido à interdependência de três fatores: a) a tectônica; b) a erosão e c) a litologia.

Assim, os movimentos tectônicos e a erosão atuam quase simultaneamente, mas com certo desfaçamento e com o seguinte esquema de evolução: "Um movimento tectônico (dobramento, deslocamento ou levantamento massivo) origina um relevo, reativa a erosão, esta ataca o relevo até aplainá-lo, mas como a erosão atua de forma diferencial (erosiona diferencialmente as rochas expostas segundo a natureza das mesmas), produz diversas formas litológicas; esquema que se complica pelas diversas interrupções, tais como a reativação tectônica (neotectônica) e/ou pelas modificações da força dos agentes erosivos e de seus processos devido principalmente às mudanças climáticas. 
Há diversas teorias que tentam explicar a origem dos relevos terrestres, sendo a primeira a do geógrafo norte-americano William Morris Davis, que em 1989, idealizou um modelo de evolução do relevo de uma área até atingir um aplainamento completo, conhecido como ciclo de erosão fluvial, o qual é constituído por uma série de etapas evolutivas, correspondentes ao grau de dissecamento e redução do relevo e resumido em três estágios básicos: juventude, maturidade e velhice (Figura la).

A teoria de Davis fundamenta-se na suposição de longos períodos de estabilidade eustática, separados por períodos considerados curtos e instantâneos de movimentação eustática ou tectônica. A grande força da teoria de Davis baseia-se na existência das superfícies de erosão, as quais constituem sua própria evidência, assim como no paralelismo das superfícies cíclicas (Derruau, 1966).

Segundo a teoria de Davis, uma série de cimeiras culminantes em níveis sensivelmente iguais seriam as evidências da existência de um antigo peneplano. No entanto, Penck (1919) demonstrou que tal fato poderia ser explicado sem a intervenção de um peneplano ou de um nível de base fixo, podendo o mesmo ocorrer numa montanha em plena fase de elevação.

Mais tarde, Penck (1953) explicou a evolução do relevo sob condições estáveis como a de uma remoção uniforme dos detritos, ocorrendo um recuo paralelo do declive e fazendo com que a cimeira não mude de forma nem de altura, permitindo que as superfícies antigas sejam conservadas como superfícies geomórficas reliquiais, facilmente identificáveis na paisagem (Figura 1b).

Por outro lado, Hack (1960) estabeleceu a idéia do equilíbrio dinâmico como modelo de evolução do relevo, no qual todos os elementos topográficos e o rebaixamento acontecem na mesma taxa, que pode variar de acordo com a natureza do material litológico, encontrando-se as formas e os processos em estado de equilíbrio dinâmico e sendo independente do tempo (Figura lc). Esta definição não permitiria a existência de superfícies relíquias, porém o autor reconhece a existência das mesmas, 
nas formas de terraços e planícies costeiras. O equilíbrio dinâmico requer duas forças em sentido oposto e da mesma intensidade afim de serem eliminadas mutuamente, teoria que tem aplicação em sistemas com igual fluxo de entradas e de saídas.

Outro modelo de evoluçāo de colinas foi estabelecido por King (1953), onde os diferentes segmentos de uma vertente sofrem erosão, porém, os de maior declive (escarpas) mantêm o ângulo e a uniformidade do comprimento dos outros segmentos, com exceção da concavidade do perfil que aumenta de tamanho gradativamente (Figura lef).

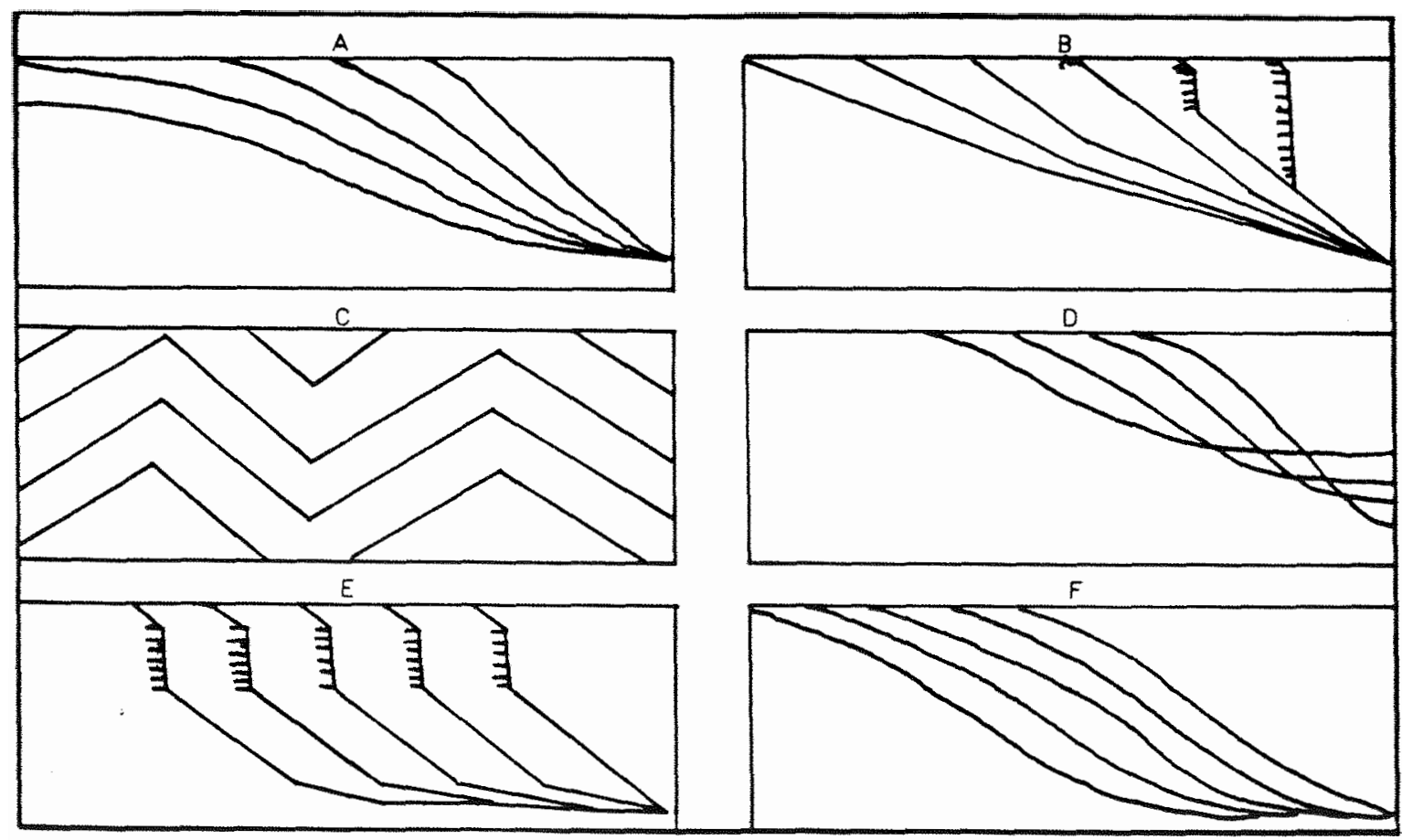

Figura 1 - Alguns modelos de evolução do relevo: a) redução da pendente, b) reposição da pendente, c) equilíbrio dinâmico, d) recuo diferencial, e) recuo paralelo com escarpa e f) recuo paralelo sem escarpa. 
Ruhe et al. (1967) também reconheceram o recuo das vertentes, mas não de forma paralela, como foi proposto por Penck e King, mas sim com a parte superior da vertente recuando e perdendo mais material que na área próxima ao canal de drenagem, a qual também considera a possível ocorrência de antigas superfícies remanescentes (Figura 1d).

Outra abordagem foi dada por Millot (1982), que defendeu a teoria de uma maior influência do intemperismo químico nas perdas de matéria em profundidade, influindo indiretamente na evolução do relevo e recentemente, alguns trabalhos feitos no Brasil por pedólogos e geomorfólogos, em forma conjunta, consideraram a hipótese de que a evolução do relevo nas regiões tropicais e sub-tropicais podem ter sido influenciados predominantemente por processos de "erosão geoquímica" (Pellerin \& Queiroz Neto, 1992; Filizola \& Boulet, 1993).

Segundo Moura (1994), a importância do clima na evolução de relevo começou a ser estudada por causa da natureza incompleta dos registros sedimentares, os quais preservam, de maneira menos subjetiva, informações a respeito da história erosiva e deposicional de uma determinada área.

A teoria largamente aceita para explicar a regularidade e a frequência das oscilações climáticas no Quaternário foi elaborada por Milankovitch (1941), a qual está baseada na admissão de que as variações extremas da temperatura da superfície terrestre estão relacionadas às modificações periódicas e de magnitudes variadas na órbita e no eixo terrestres, as quais afetariam a quantidade de radiação solar recebida e seriam responsáveis pelas grandes mudanças climáticas acontecidas no passado.

Segundo Fairbridge (1968), as mudanças ambientais significativas associaram-se aos eventos glaciais, não podendo ser consideradas como fenômenos exclusivos das regiōes afetadas diretamente pelas glaciações, havendo indícios de um zoneamento climático global: durante os episódios de avanço das geleiras nas regiões glaciais, as regiões tropicais e subtropicais (não-glaciais) tornaram-se muito mais secas 
em decorrência de uma baixa generalizada na precipitação a nível mundial ligada ao resfriamento das águas oceânicas; em contrapartida, durante os períodos interglaciais, ocorreram condições úmidas e tropicais mais generalizadas.

A aplicação desta teoria na evolução do relevo terrestre foi desenvolvida por Holmes (1955), na qual um relevo originado pela tectônica ou por um clima semiárido evolui através da diminuição da vertente de gravidade, sob a ação de um clima úmido que aumenta a taxa de intemperismo e da erosão superficial na vertente de lavagem, tornando-se convexo (Figura 2a). Em situação inversa e, quando o clima se torna seco, a encosta possui formas convexas e na medida que o rio atinge o equilíbrio, pára de escavar verticalmente e começa a alargar o vale, predominando os processos areolares, a vertente recua e sua base torna-se côncava (Figura $2 b$ ).

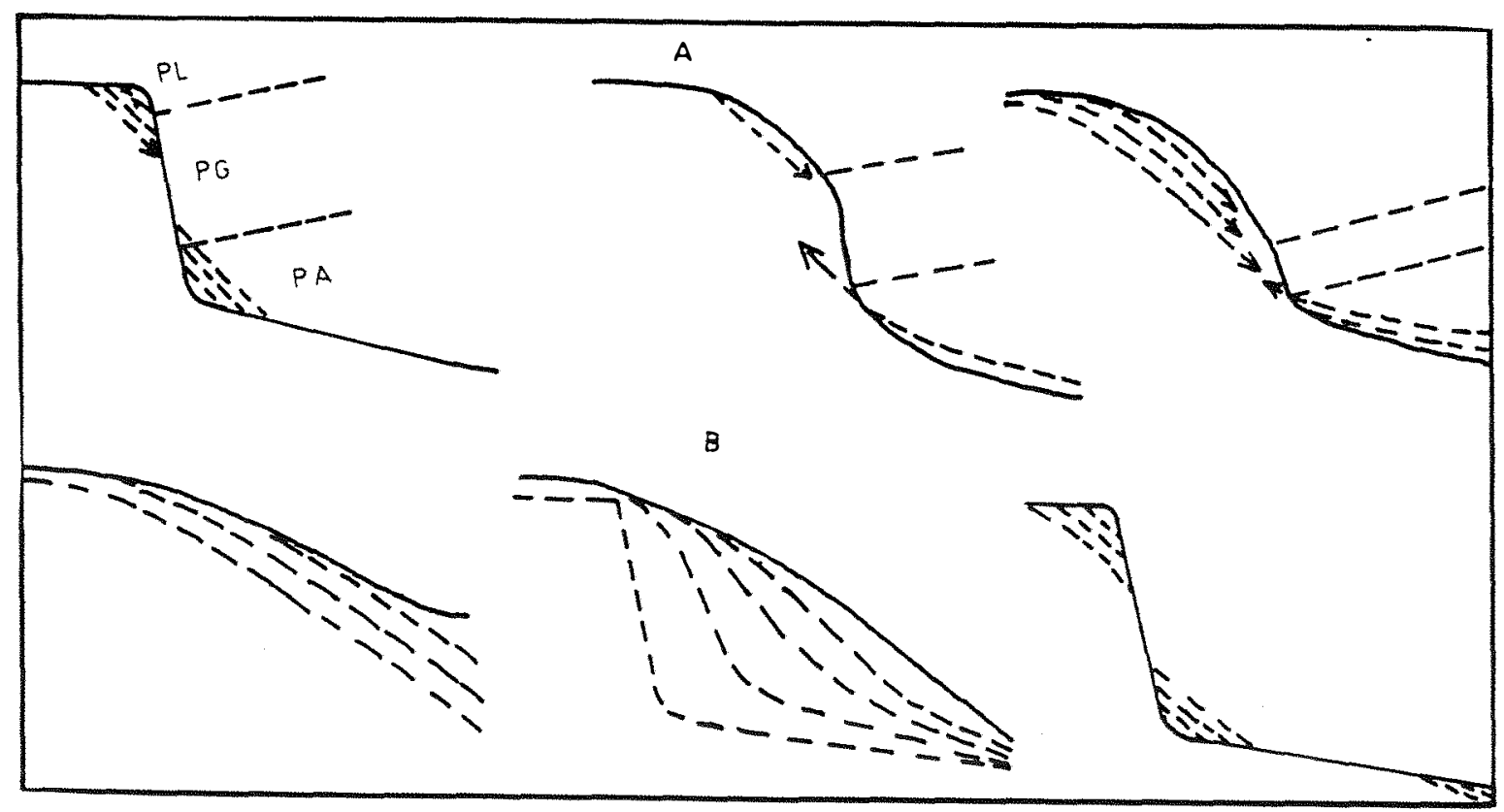

Figura 2 - Evolução do relevo ao longo do tempo com alternância de climas: a) do seco para o úmido e b) do úmido para o seco. 
Segundo Moura (1994) a análise estratigráfica dos sedimentos quaternários deve considerar os diferentes padrões de organização das paisagens, integrando a geomorfologia com a estratigrafia, e a perspectiva morfoclimática adotada por Bigarella e colaboradores no estudo do quaternário brasileiro (Bigarella \& Mousinho, 1965; Bigarella et al., 1965), identificando uma superfície de erosão e seus depósitos correlativos, enquadra-se nesta abordagem integrativa assim como no enfoque climático de Holmes. Embora esta perspectiva tenha representado um avanço importante no sentindo de melhorar a compreensão sobre a evolução do relevo terrestre, tem sido discutida como de difícil aplicação, pois o reconhecimento no campo das relações propostas não é fácil e não existe uma correlação cronogeológica bem definida, além da possibilidade de que os movimentos tectônicos quaternários tenham atuado no escalonamento das superfícies (Moura, 1994).

Por isso, nos últimos anos, o papel da tectônica tem sido considerado como importante fator de controle da evolução do relevo. Assim, Hasui (1990) acreditou que uma "tectônica ressurgente" pode ter afetado certos compartimentos e formas do relevo brasileiro. Em áreas colinosas e visivelmente escalonadas é provavel que o papel da tectônica tinha sido de grande importância na distribuição dos materiais de origem dos solos na paisagem, afetando não somente a morfogênese superficial mas também o padrão de distribuição espacial dos solos e conseqüentemente a evolução dos processos pedogenéticos ${ }^{1}$.

\subsection{Gênese e desenvolvimento do solo}

O primeiro estudo dos fatores de formação do solo foi realizado por Dokuchaev no século passado, segundo a qual o solo se forma em função de quatro

\footnotetext{
' GIMENEZ, R.J. Cominicação pessoal em Rio Claro. SP., 1977.
} 
fatores: o clima, os organismos vivos, o material parental e o tempo. Mais tarde, Hildgard citado por Jenny (1961b) e por Shaw (1930), agregaram um quinto fator: o relevo.

Segundo Gerrard (1995) o problema com a equação é a grande dificuldade para quantificar os diferentes fatores envolvidos. As litofunções apresentam problemas porque é difícil dar valores numéricos aos materiais parentais. As topofunções são mais fáceis de serem exemplificadas graficamente, mostrando relações entre as propriedades dos solos e os elementos da paisagem como o declive e a posição topográfica, mas também há problemas para ajustar relações lineares ou curvilíneas porque os ângulos do declive $\mathrm{e}$ as propriedades dos solos estão fortemente autocorrelacionadas, não sendo independentes e invalidando portanto as relações estatísticas encontradas. Tal autor ainda sugere que há muitos estudos qualitativos de climofunções com resultados que podem ser quantificados no futuro e também existem soluções numéricas de funções bióticas, ainda que raras, mas que permitem conhecer bem o papel da vegetação na formação do solo.

Grande número de estudos foram realizados para quantificar a taxa de desenvolvimento de uma propriedade do solo com o tempo, porém não é só a taxa que varia de uma propriedade para outra mas também o tipo de função matemática e vários autores revisaram o problema das cronofunções (Vreken, 1975; Yaalon, 1975; Bockheim, 1980), concluindo que a direção do desenvolvimento do solo, ou seja, o desenvolvimento progressivo não é o único caminho da pedogênese, podendo acontecer interrupções e até retrocessos, como resultados da instabilidade das "landforms" ou dos processos geomórficos.

Um passo muito importante para a determinação das cronofunções é o desenvolvimento de índices que possam mostrar o grau de desenvolvimento dos diferentes solos de uma paisagem, no qual a macromorfologia e a micromorfologia são ferramentas úteis, tanto para a determinação das discontinuidades dos materiais parentais 
como dos processos antigos que intervieram na formação histórica do solo mas que não estão mais atuantes hoje.

Segundo Brewer (1976), as análises mineralógicas quantitativas podem ser usadas para estimar ganhos e perdas de peso, espessura, volume e constituintes dos horizontes por causa dos processos de formação do solo; mas, a precisão dos cálculos dependem da validade das considerações relacionadas com a uniformidade do material de origem, com a seleção do verdadeiro material parental e com as propriedades do constituintes estáveis.

A seleção do constituinte mais estável é problemática porque todos podem ser mobilizados sob certas condições ambientais e em alguns perfís podem, ser totalmente móveis, sendo os mais utilizados o zirconio $(\mathrm{Zr})$, os metais pesados, o quartzo + albita por peso, a porcentagem de areia fina por peso e a porcentagem de turmalina por peso (Brewer, 1976). Demattê (1978), por exemplo, recomendou utilizar uma diferença superior a $100 \%$ no teor de $\mathrm{Zr}$ entre horizontes do solo como critério para determinar se há discontinuidade litológica e quando não houver no solo evidências morfológicas da mesma.

Outra análise importante para definir diferentes graus de desenvolvimento do solo é a utilização do índice de intemperismo e segundo Birkeland (1984) as relações molares dos componentes químicos a serem calculadas são as seguintes:

- $\mathrm{SiO}_{2} / \mathrm{Al}_{2} \mathrm{O}_{3}$ (índice $\mathrm{Ki}$ )

$-\mathrm{SiO}_{2} / \mathrm{Fe}_{2} \mathrm{O}_{3}$

- $\mathrm{SiO}_{2} /\left(\mathrm{Al}_{2} \mathrm{O}_{3}+\mathrm{Fe}_{2} \mathrm{O}_{3}\right)$ (índice $\mathrm{Kr}$ )

$-\mathrm{SiO}_{2} /\left(\mathrm{Al}_{2} \mathrm{O}_{3}+\mathrm{Fe}_{2} \mathrm{O}_{3}+\mathrm{TiO}_{2}\right)$

$-\left(\mathrm{K}_{2} \mathrm{O}+\mathrm{Na}_{2} \mathrm{O}+\mathrm{CaO}+\mathrm{MgO}\right) / \mathrm{Al}_{2} \mathrm{O}_{3}$

- Bases $/ \mathrm{R}_{2} \mathrm{O}_{3}$

Todos esses índices diminuem com o aumento do intemperismo em ambiente de lixiviação. A estabilidade dos minerais, as condições sob as quais se 
formaram e os produtos resultantes do intemperismo devem ser considerados para se entender melhor a gênese dos solos, sendo para isto muito importante as análises mineralógicas, segundo as quais, os minerais dos solos são agrupados arbitrariamente em minerais primários e secundários.

Segundo Brewer (1976) os minerais primários são aqueles já presentes no material parental no início da formação do solo, e secundários, aqueles formados durante o desenvolvimento do solo pelo intemperismo de minerais pré-existentes. No entanto, esta discriminação pode ter exceções importantes, principalmente quando são realizados estudos muito detalhados da gênese do solo, assim, um sedimento originado a partir de um solo preexistente, onde a maior parte dos seus minerais primários já foram transformados em minerais secundários, estes deverão ser considerados primários para um novo ciclo de formação de solo em um ambiente diferente daquele onde o material foi intemperizado, pedogenizado e erodido.

Segundo Haseman \& Marshall (1945), a estabilidade ou resistência das espécies minerais depende de muitos fatores, incluindo dureza, clivagem e coeficiente de expansão, fraturas originais dos cristais e solubilidade sob ambientes específicos e em certas circunstâncias. Outros fatores tais como tamanho de grãos, podem ser importantes.

Vários pesquisadores têm classificado os minerais primários de acordo com sua estabilidade ou resistência ao intemperismo (Brewer, 1976), havendo discrepância com relação à ordem assinada aos mesmos na seqüência de intemperismo. Tal fato pode ser explicado pela variação nas características físico-químicas de cada mineral específico estudado em cada caso e pelas diferenças dos ambientes onde foram obtidos os dados. Por isso, esses dados devem basear-se em solos formados de materiais parentais uniformes afim de se analisar se as possíveis ordens de resistências são devidas à variações do material parental ou às diferenças de microambientes pedogenéticos. 
Assim, Jackson \& Sherman (1953) estabeleceram uma seqüência de intemperismo para minerais da fração argila (tamanho igual ou menor que $2 \mu$ ), constituído em 13 estágios a seguir:

1. Gipsita (também Halita, $\mathrm{Na}_{2} \mathrm{NO}_{3}, \mathrm{NH}_{4} \mathrm{CL}$, etc)

2. Calcita (também Dolomita, Aragonita, Apatita, etc)

3. Olivina e hornblenda (também Piroxeno, Diopsido, etc)

4. Biotita (também Glauconita, $\mathrm{MgCl}_{2}$, Antigorita, Nontronita, etc)

5. Albita (também Anortita, Stilbita, Microclina, Ortoclasio, etc)

6. Quartzo (também Cristobalita, etc)

7. Moscovita (também Sericita, Ilita com espaços de $10 \AA$ )

8. Silicatos interestratificados 2:1 e Vermiculita

9. Montmorilonita (também Beidelita, Saponita, etc)

10. Caulinita (também Haloysita, etc)

11. Gibbsita (também Boehmita, Alofana, etc)

12. Hematita (também Goetita, Limonita, etc)

13. Anatásio (também Zircão, Rutilo, Ilmenita, Leucoxênio, Corindon)

A aplicação desta seqüência possibilita determinar: a) o que ocorre na rocha durante a sua decomposição e posterior formação do solo; b) As transformações que ocorrem no solo; c) O curso da meteorização de um solo ou de um sedimento e interpretar a ordem de sucessão dos minerais durante o processo de intemperização, porém deve ser levado em conta que tais transformações mineralógicas nem sempre ocorrem necessariamente nesta seqüência. Por outro lado, Jackson et al. (1948) utilizaram esta seqüência para estabelecer um índice médio de intemperismo, o qual pode ser calculado pela seguinte expressão:

$$
I M=\frac{\sum(P \cdot S)}{\sum S}
$$


onde, $\mathrm{IM}=$ intemperismo médio; $\mathrm{P}=$ estádio de intemperização do mineral e $\mathrm{S}=$ porcentagem do mineral no horizonte do solo

Alguns pesquisadores (Demattê, 1970) têm usado este índice para comparar o grau de desenvolvimento dos solos formados em diferentes superfícies pedogeomórficas e como a maioria das propriedades do solo são dependentes do tempo (Jenny, 1941), outros índices melhores podem ser utilizados para tal fim.

Vários pesquisadores (Shaw, 1928; Gile et al, 1966; Bilzi \& Ciolkosz, 1977) têm utilizado com sucesso a morfologia do solo para estimar os processos pedogenéticos básicos com o fim de avaliar o desenvolvimento do solo em função do tempo. Harden (1982) e Dorronsoro \& Alonso (1994), por exemplo, aplicaram um índice de desenvolvimento do perfil (IDP) baseado em dados morfológicos dos solos desenvolvidos em terraços aluviais, encontrando uma boa correlação entre o grau de evolução dos solos e a idade dos terraços, porém, Harden \& Taylor (1981) aplicando o IDP baseado em características morfológicas em cronosseqüências de solos desenvolvidos em diferentes regimes climáticos, concluiram que algumas propriedades do solo não são aplicáveis a todos os climas.

A utilidade da aplicação do IDP baseado em caraterísticas morfológicas para estimar a evolução dos solos foi confirmada por Bussaca (1987), quem encontrou boa correlação linear de oito processos e atributos do solo (rubeficação, textura total, estrutura, consistência em seco, consistência úmida, cerosidade e melanização) com o $\log$ da idade dos mesmos.

\subsection{Modelos de solo-paisagem}

O aumento das informações detalhadas a respeito das mudanças climáticas no passado, das flutuações no nível do mar, das variações nos movimentos dos continentes e da neotectônica, indicam que houve grandes mudanças durante os 1,5 
milhões de anos do período quaternário e ainda muito mais, se considerarmos os 65 milhões de anos do período terciário (Gerrard, 1995). Este fato permitiu que a Geomorfologia e a Pedologia se integrassem nas últimas décadas, dando origem a um novo campo de pesquisa que integra estas duas disciplinas.

Segundo Daniels \& Hammer (1992), o estabelecimento das relações e as influências da hidrologia e da topografia de uma vertente sobre a gênese dos seus solos, somente poderá ser comprendido se a influência da estratigrafia e da geomorfologia sobre a pedologia for reconhecida.

O reconhecimento de que uma forma particular do relevo associada com uma seqüência particular de solos permitiu a formulação do conceito de "catena", o qual foi o primeiro modelo de solo-paisagem estabelecido por Milne (1935). Este autor definiu a catena como sendo "uma unidade de mapeamento conveniente ...., um agrupamento de solos que se encontra em classes separadas do sistema de classificação natural devido às diferenças fundamentais e morfológicas, mostrando que os solos estão interligados por condições topográficas e que ocorrem repetitivamente na paisagem com a mesma relação entre os mesmos quando se tem as mesmas condições ambientais". Este autor desenvolveu o conceito de catena com base em estudos de relação solo-relevo realizados no Leste da África, concluindo também que o processo erosivo é um dos fatores mais importante de diferenciação dos solos sob condições climáticas constantes e relacionados a um material de origem comum, sugerindo mais tarde que a caraterística e a extensão dos solos variam com a maturidade do relevo, o tipo de litologia e os novos ciclos de erosão (Milne, 1936).

Mais tarde, Dalrymple et al. (1968) idealizaram um modelo bidimensional de uma catena composta por nove unidades, baseada tanto na morfologia superficial como nos processos pedogenéticos e geomórficos, segmentando o perfil topográfico e integrando seus componentes segundo a movimentação do material e da água (Figura 3 ), os quais (unidades geomórficas de respostas e os processos envolvidos) podem ser 
mapeados detalhadamente em áreas de grande extensão. Porém, a aplicação do modelo de Dalrymple pode estar restrita a certas paisagens relativamente estáveis das regiões temperadas, havendo problemas para sua aplicação em paisagens montanhosas e de altitude, onde outros modelos baseados nas formas da terra ("landforms") seriam mais apropriados (Gerrard, 1992).

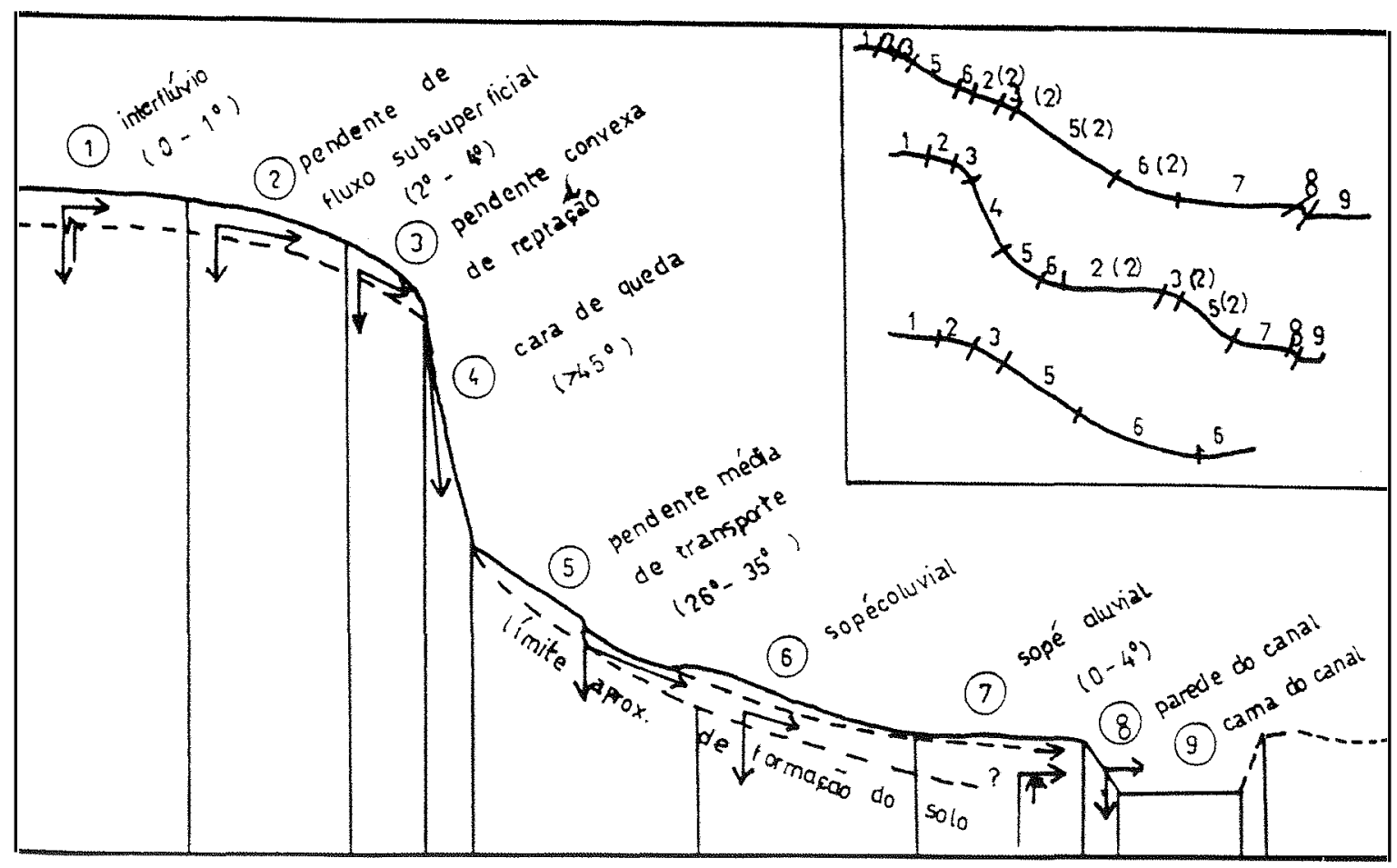

Figura 3 - Modelo bidimensional de nove unidades geomórficas de solo-relevo de uma catena hipotética proposto por Dalrymple et al. (1968). 
Por outro lado, Ruhe et al. (1967) desenvolveram um modelo para o estudo de relações solo-paisagem a partir de intensos trabalhos na região sudoeste de Iowa (EUA), no qual foram identificadas e mapeadas diferentes superfícies geomórficas correspondentes à diferentes ciclos erosivos da paisagem.

À exceção do modelo de Milne, a maioria dos modelos foram desenvolvidos em regiōes temperadas, ficando a dúvida sobre a aplicabilidade dos mesmos em regiōes tropicais e subtropicais, onde os componentes da evolução das superfícies, tais como taxas de erosão, intensidade de lixiviação, mobilidade de soluções fluídas, variabilidade vertical e lateral do fluxo da água e transporte de materiais, entre outros, podem ser bastante distintos com relação àqueles encontrados em climas temperados.

Um modelo de relação solo-paisagem indicado para áreas pouco conhecidas é o do "Landsystem", o qual está baseado no reconhecimento e na interpretação de fotografias aéreas, onde a paisagem é segmentada em diferentes padrões de geomorfologia, solo e vegetação, dando lugar às macrounidades denominadas "Landsystems". Esta metodologia proposta por Christian \& Stewart (1958) foi utilizada amplamente pela Organização de Pesquisa Científica e Industrial do Reino Unido (CSIRO) da Austrália (Espanha, 1991).

Por outro lado, Godfrey (1977) utilizou um enfoque estritamente fisiográfico na definição dos níveis hierárquicos das "Landforms", permitindo sua aplicação em estudos básicos para a planificação do uso das terras. Assim, em uma determinada região existem diferentes grupos de "landforms", cada qual com sua própria história geológica e geomórfica distinta e cuja semelhança dentro de cada grupo se traduz em semelhante aptidão para os diversos usos da terra.

Com o mesmo enfoque fisiográfico, Goosen (1971) estudou as relações solo-paisagem nos "Llanos Orientales" da Colombia, onde encontrou correspondências entre as propriedades dos solos e os diferentes processos geomórficos, tais como erosão e movimentos de massa em diferentes unidades fisiográficas delimitadas. 
Segundo Goosen (1968), a análise fisiográfica das paisagens concentra-se mais nos processos do que nos fenômenos observados, sendo os principais: a erosão, a sedimentação, a tectônica e os vulcanismos. Este autor ressaltou que o passo mais importante da análise fisiográfica é reconhecer e identificar o processo básico atuando em cada caso específico.

Nas últimas décadas, alguns pesquisadores têm encontrado relações entre a ordem da drenagem e o relevo, e como os solos podem estar relacionados com o relevo é de se esperar que existam relações entre os solos e as diferentes ordens de drenagem (Strahler, 1954; Finney et al., 1962; Losche et al., 1970; Churchill, 1982). Esta hipótese foi testada por Gerrard (1982), quem estudou as relaçōes solopaisagem em microbacias do sudoeste da Inglaterra, onde encontrou as seguintes relações hierárquicas entre os solos e as características da paisagem: a) relaçōes gerais na paisagem; b) relações dentro de uma unidade de drenagem; c) relações solo-relevo, e d) relaçōes em unidades individuais de formas da terra ou das "landforms".

\subsection{Unidades de solos}

Segundo Duchafour (1982) o solo é formado principalmente por três processos naturais: a incorporação da matéria orgânica, o intemperismo das rochas e o movimento de materiais dentro do solo. Estes processos promovem uma progressiva diferenciação de horizontes, tendo a pedologia como objetivo básico, estabelecer as relações entre estes processos e o ambiente.

O Soil Survey Staff definiu o solo como "uma coleção de corpos naturais da superfície terrestre, em lugares modificados pelo homem com material térreo, contendo matéria vivente e suportando ou sendo capaz de suportar plantas ao ar livre. Seu limite superior é o ar ou a água superficial. Nos lados pode limitar gradativamente com áreas alteradas da rocha ou com gelo. Seu limite inferior é o mais difícil de 
estabelecer. O solo inclui os horizontes superficiais que se diferenciam do material rochoso como resultado de interações, através do tempo, do clima, dos organismos vivos, do material de origem e do relevo. Nos poucos lugares onde há horizontes cimentados impermeáveis às raízes, o solo tem a profundidade do horizonte mais profundo. Mais comumente, o solo transiciona no limite inferior para o material rochoso ou material térreo explorado pelas raízes e pelos animais, sendo portanto, o limite inferior, o indicado pela atividade biológica, o qual coincide geralmente com a profundidade atingida pelas raízes das plantas perenes" (Estados Unidos, 1975).

Por outro lado, Brewer (1976) define o solo para fins dos estudos pedográficos como sendo: "uma coleção de corpos naturais formados por alteração de corpos sedimentares e/ou ígneos, devido a reposição na superfície terrestre e tendo um arranjo anisotrópico de suas propriedades ao longo de um eixo normal à superfície da terra". Para atingir o objetivo da pedologia, que é o de elucidar a origem e a gênese dos materiais do solo e dos perfís de solos, a pesquisa não pode se concentrar somente no material do solo e nos perfis dos solos, mas também estudar exaustivamente as rochas e as modificações dos materiais e rochas parentais ocasionadas pelos processos de formação de solos, sendo portanto necessário conhecer bem as características destes últimos (Brewer, 1976).

Wilding et al. (1983) acreditaram que não há ainda total acordo entre os cientistas de solos sobre qual é a unidade básica ou referencial que possa suportar o conceito fundamental do solo e que ao mesmo tempo seja independente de qualquer sistema de classificação, isto porque, até agora, os conceitos pedogenéticos têm influenciado muito os sistemas de classificação taxonômica mais do que os conceitos de uso e/ou os de levantamento de solos. Este fato foi auspicioso, segundo eles, porque o conceito que define o solo como um material alterado em constante evolução aponta para uma definição real do solo e de sua evolução, complicando e expandindo as possibilidades de produzir critérios úteis para a construção de sistemas de classificação 
mais adequados. Com este objetivo, Van Wambeke (1966) estabeleceu que uma unidade básica ou referencial do solo deveria reunir as seguintes qualidades:

a) Ser um objeto observável e medível nas três dimensões.

b) Ser independente de todo sistema de classificação.

c) Ter limites claros, ainda que fossem estabelecidos arbitrariamente.

d) Ter um tamanho conveniente para ser estudado, medido e amostrado.

Além da influência dos processos pedogenéticos na conceituação do solo houve forte influência do levantamento e mapeamento, no qual se dá grande importância ao estudo dos solos como corpos de natureza geográfica, ainda que concebido e determinado por uma única relação existente entre uma série de propriedades observadas à campo (Estados Unidos, 1975). O levantamento de solos, segundo Wilding et al. (1983), identifica corpos de solos que podem ser reconhecidos como unidades naturais, cuja ocorrência na paisagem pode ser predita e delimitada em mapas, mas também identificados em termos de classes definidas por um sistema de classificação.

A arte e a escala utilizada na elaboração dos mapas de solos e o reconhecimento de corpos de solos interdigitados na paisagem e com qualidades contrastantes impedem delimitar áreas com os mesmos limites de variabilidade estabelecidos pela classe taxonômica, fazendo que haja necessidade de uma ponte entre as classes taxonômicas e os limites projetados pela variabilidade natural dos solos na paisagem, ou seja, de uma unidade geográfica básica do solo e como esta unidade geográfica básica do solo é necessariamente dependente do sistema taxonômico utilizado, não servindo portanto, para comparar os diferentes sistemas de classificação (a diferença da unidade básica ou referencial do solo).

Hole (1953) propôs o "corpo do solo" como sendo um espécime da unidade taxonômica similar ao tipo de solo, que limita as unidades de perfil baseado nas fases características do perfil, e Van Dijk (1959) definiu o "componente da superfície 
terrestre" como sendo uma subdivisão da superfície terrestre baseado na variação do material parental, particularmente se o material for erosional ou deposicional, incluindo todas as superfícies de erosão, de deposição e de camadas que se desenvolveram numa paisagem durante um intervalo de tempo onde um manto de solo foi desenvolvido sem cortes estratigráficos.

A "unidade estratigráfica do solo" foi idealizada pela American Commission of Stratigraphic Nomenclature (1961), como sendo um solo com feições físicas e relações estratigráficas que permitem seu reconhecimento e mapeamento como uma unidade estratigráfica. Por outro lado, Muir (1962) propôs a "unidade de áreasolo", como sendo áreas que têm um padrão morfológico similar ao perfil de formato "standard" do sistema de classificação.

O "polipedon", proposto por Johnson (1963) é um grupo contínuo de pedons similares, limitados por materiais edáficos ou por pedons, com características diferentes. Os limites dos polipedons são também considerados limites conceituais entre as séries de solos, categoria mais baixa no "Soil Taxonomy", e mais tarde, Gibbons \& Downes (1964) propuseram o "componente da terra" como sendo uma área de clima, material parental, topografia, solo e vegetação uniforme dentro de limites significativos para uma forma particular de uso da terra e cujo menor tamanho corresponde ao menor tamanho de terra que um agricultor pode aplicar uma prática de manejo diferenciada.

A "área elementar do solo" proposta por Fridland (1965) é uma área com característica do solo que identifica a unidade taxonômica mas também definido pela sua área, pelo seu grau de dissecação e pela sua forma, a qual é uma constituinte primária do solo que pertence a alguma unidade de classificação de nível mais baixo.

Van Wambeke (1966) propôs o "corpo artificial do solo" como sendo um indivíduo ou segmento coerente com o solo, o qual é criado pelo classificador afim de se aproximar ao corpo natural do solo, sendo o mesmo distinto e independente do observador. 
A "forma pedomórfica" proposta por Dan \& Yaalon (1968) é uma unidade de solo caracterizada por horizontes definidos que refletem seu grau de maturidade e sua história erosional ou deposicional, a qual é concebida como um segmento de uma seqüência quaternária de formas pedomórficas relacionadas por influência da topografia na gênese e que estão localizadas ao longo de uma toposeqüência.

Por outro lado, há diferentes formas de apresentar a distribuição dos solos nos mapas e legendas dos levantamentos de solos. Assim, no levantamento convencional de solos (sem fotointerpretação) a seqüência de mapeamento começa pela identificação dos aspectos externos da paisagem, segue com a identificação dos aspectos internos (em trincheiras) e finaliza com a delimitação em mapas. Porém, quando o levantamento é baseado na fotointerpretação, a seqüência de mapeamento começa pela identificação dos aspectos externos da paisagem identificados nas fotos aéreas, continua com delimitação e termina com a identificação dos aspectos internos em trincheiras.

Segundo Goosen (1968) dentro de uma unidade fisiográfica podem ocorrer várias séries de solos que não podem ser identificados pelos aspectos externos, o qual é o caso de solos diferenciados por processos fisiográficos acontecidos no passado e que se encontram atualmente inativos. Porém, como os solos reagem às mudanças ambientais ajustando-se lentamente aos fenômenos fisiográficos recentes, ainda mantêm nas suas características internas muitos processos anteriores, razão pela qual as unidades delineadas durante a fotointerpretação podem ter impurezas desconhecidas (inclusões).

$\mathrm{O}$ uso de um único nome de solo para denominar a unidade de mapeamento composta não oferece informação imparcial sobre a composição da mesma, sendo omitidas as características e propriedades de solos valiosas para o manejo dessa unidade, podendo ser mais útil representar os solos da unidade como uma associação dos mesmos e introduzindo o conceito fisiográfico na legenda, a fim de proporcionar informação valiosa para sua localização, metodologia sugerida anteriormente por Milne (1936) e, recentemente, por Goosen (1968). 
A composição mais adequada das unidades de mapeamento e a elaboração de mapas que mostram as caraterísticas dos solos e da paisagem constituem uma evolução importante no que se refere à qualidade dos levantamentos, porque podem fornecer uma informação mais completa sobre a superficie terrestre, o que somado à disponibilidade atual de meios computarizados para o processamento da informação, constituem avanços relevantes da ciência aplicada ao conhecimento, ao uso e ao manejo sustentável do recurso solo.

Segundo "Soil Sourvey Staff" (1994), na maioria dos levantamentos detalhados de solos, as inclusões de solos perfazem até 50\% da área das unidades de mapeamento, isto porque o mapeamento baseia-se principalmente na aerofotointerpretação das feições superficiais da terra, como quebras no relevo, deferenças na tonalidade e na textura da fotografia produzidas pelas condições superficiais dos solos (umidade, materia orgânica, granulometria e mineralogia), usos da terra e da vegetação. Se esta heterogeneidade das unidades de mapeamentos de solos é uma constante nos levantamentos detalhados de solos, nos levantamentos semidetalhados de solos deve haver ainda maior heterogeneidade das unidades de mapeamentos, sendo portanto mais importante levar en consideração os aspectos fisiográficos na elaboração das unidades de mapeamento. 


\title{
3 MATERIAL E MÉTODOS
}

\subsection{Caracterização da área de estudo}

\subsubsection{Localização}

\begin{abstract}
A Serra de "Ybycu'i", conhecida comumente por "Cordillerita" encontrase a aproximadamente $150 \mathrm{~km}$ a Sudeste da capital do Paraguai, "Assunción", nos distritos de "La Colmena" e de "Ybycu'i" do Departamento de Paraguari, nas seguintes coordenadas geográficas: $25^{\circ} 55^{\prime}$ e $26^{\circ} 05^{\prime}$ Sul, $56^{\circ} 35^{\prime}$ e $57^{\circ} 00^{\prime}$ Oeste (Figura 4).
\end{abstract}

\subsubsection{Clima}

Segundo o sistema de classificação de Köeppen, o clima da região é do tipo temperado chuvoso (Cfa), com uma precipitação pluvial média anual de $1600 \mathrm{~mm}$ concentrado no semestre quente (outubro a março), sendo a temperatura média anual de $22^{\circ} \mathrm{C}$ (Instituto, 1985) (Figura 4).

Na Tabela 1 são apresentadas as médias mensais de precipitação pluvial, temperatura e o balanço hídrico calculado pelo método de Thornewaite, correspondente a um período de 30 anos (1961-1990) da Estação Meteorológica de Villarrica, distante a $50 \mathrm{~km}$ ao Leste da Serra, mostrando que pode ocorrer déficit hídrico na região durante os meses de fevereiro e dezembro. Segundo Holdridge (1969), a área de estudo corresponde à zona de vida Floresta úmida temperada, com uma relação de evapotranspiração $=0,7$ e onde pode ocorrer geadas entre os meses de maio e setembro. 


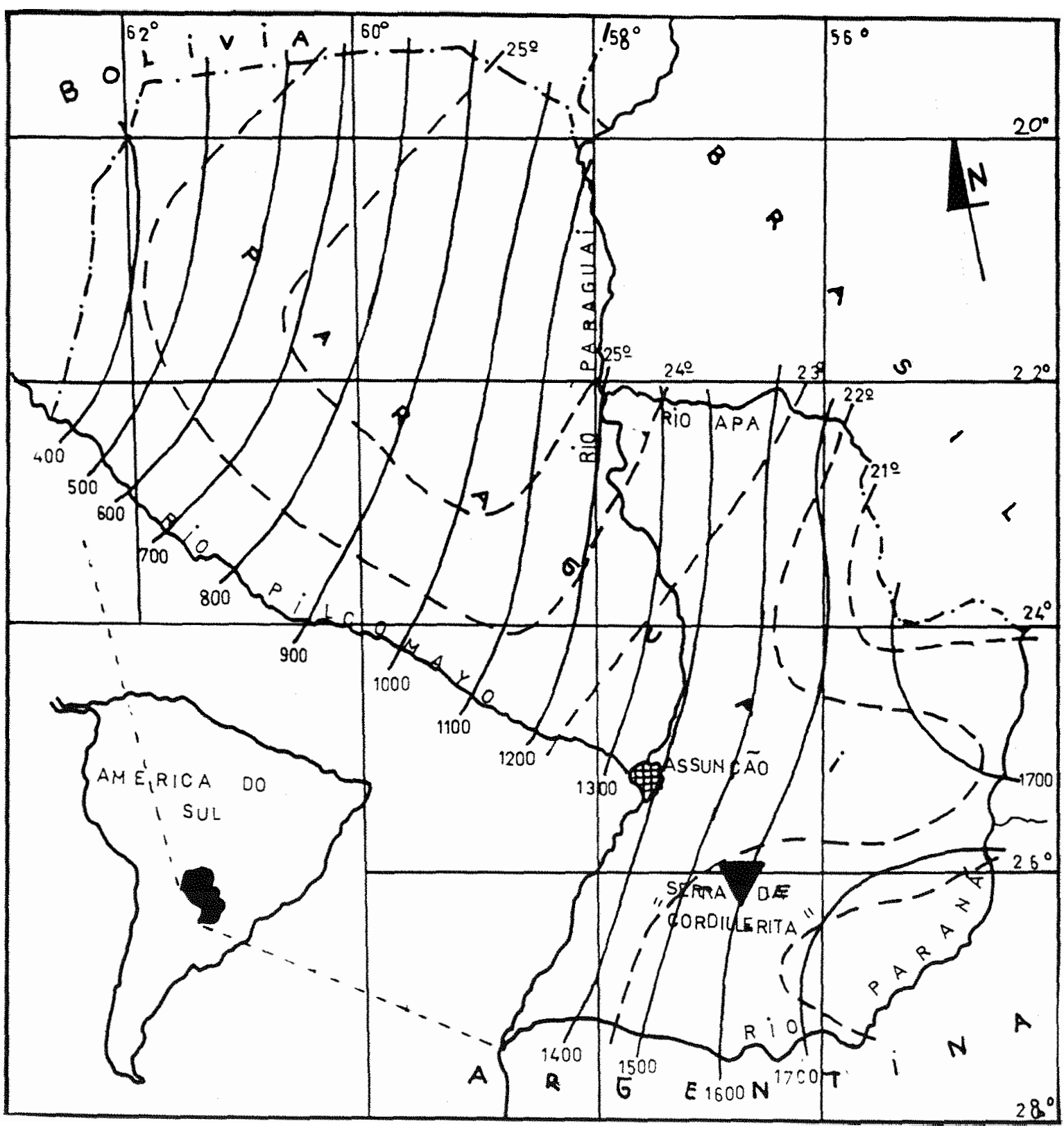

Figura 4 - Localização da Serra de "Cordillerita" no Paraguai, isoietas (- - ) e isotermas (-) médias anuais do período 1961-1990 (Instituto, 1985). 
Tabela 1 - Precipitação pluvial, temperatura e balanço hídrico, médias mensais da Estação Meteorológica de Villarrica, situada a $50 \mathrm{~km}$ ao Leste da Serra de "Cordillerita".

\begin{tabular}{cccccccccccccc}
\hline MES: & E & F & M & A & M & J & J & A & S & O & N & D & TOTAL \\
\hline Precipitação(mm) & 134 & 124 & 153 & 170 & 131 & 117 & 68 & 104 & 110 & 156 & 175 & 146 & 1643 \\
Temp.média $\left({ }^{\circ} \mathrm{C}\right)$ & 27,6 & 26,2 & 24,9 & 21,9 & 19,1 & 16,9 & 17,2 & 18,4 & 19,8 & 22.5 & 24,4 & 26,0 & 22.0 \\
Balanço Hídrico & 18 & -8 & 32 & 91 & 77 & 79 & 27 & 53 & 46 & 59 & 53 & -6 & 525 \\
\hline
\end{tabular}

Fonte: Dados proporcionados pela Direção de Meteorologia e Hidrologia do Paraguai.

Segundo Holdridge (1969), a área de estudo corresponde à zona de vida Floresta úmida temperada, com relação de evapotranspiração $=0,7$, onde há ocorrência de geadas entre os meses de maio a setembro.

\subsubsection{Geologia}

As principais unidades litoestratigráficas da área formaram-se durante o período Ordoviciano da Era Paleozóica, entre 395 e 435 milhões de anos, aproximadamente, por um processo de transgressão-regressão marinha e estão constituídas por três Formações do Grupo "Ca'acupe" (Figuras 5 e 6) (Paraguai, 1986).

Segundo Eckel (1959) a Formação "Paraguari" que é o basamento principal e mais antigo pode ter uma espessura variável de 1 a $50 \mathrm{~m}$ e consiste de um conglomerado ortoquartzítico de cascalhos dentro de uma matriz arenosa grossa, tendo os clastos uma superficie suave, elipsoides a bem arredondados de 1 a $30 \mathrm{~cm}$ de diâmetro, de natureza silícia, quartzo venoso, quartzito e várias formas de sílex e jasper, não havendo rochas ígneas ou metamórficas, exceto quartzito. 
A Formação "Cerro hū" pode ter até 450 m de espessura e conformada por um arenito arcosiano com estratificação cruzada, de cores amareladas claras a bruno avermelhadas claras, existindo solos espessos de cor bruno escuro a vermelho escuro, tendo uma granulometria mal selecionada de fina a grossa, pobremente cementada e consistente de grãos bem arredondados de quartzo e feldspato com quantidade considerável de mica.

A Formação "Tobatī" cuja espessura média é de $150 \mathrm{~m}$, formada por um arenito sacaroidal com intercalações lutíticas e composto por areias quartzíticas brancas com pouca cementação calcária e alguns grãos de magnetita, sendo os mesmos de tamanho uniforme ou bem selecionados, mas de formas irregulares que variam desde arredondado a euhedral (Paraguai, 1986; Gonzalez et al, 1996). Estas três formações

\begin{tabular}{|c|c|c|c|c|c|}
\hline \multirow{2}{*}{$\begin{array}{l}\text { EDADE } \\
\text { MA. }\end{array}$} & \multirow{2}{*}{$\begin{array}{l}\text { ÉPOCA } \\
\text { GEOLÓGICA }\end{array}$} & \multicolumn{2}{|c|}{ UNIDADE GEOLÓGICA } & \multirow[t]{2}{*}{ LITOLOGÍA } & \multirow{2}{*}{$\begin{array}{l}\text { AMBIENTE } \\
\text { PREDOMINANT }\end{array}$} \\
\hline & & GRUPO & FORMACÃO & & \\
\hline \multirow{4}{*}{345} & Carbonífero & & C. Oviedo & \begin{tabular}{|l|} 
Arenito \\
Varvito
\end{tabular} & $\begin{array}{l}\text { Glacial/ } \\
\text { Lacustre }\end{array}$ \\
\hline & \multirow{3}{*}{ Siluriano } & \multirow{3}{*}{ I tacurubí } & Kari'y & \begin{tabular}{|l} 
Arenito \\
Micacen
\end{tabular} & $\begin{array}{l}\text { Marino } \\
\text { Somero }\end{array}$ \\
\hline & & & Vargas Peña & $\begin{array}{l}\text { Siltito } \\
\text { Miracen }\end{array}$ & $\begin{array}{l}\text { Marino } \\
\text { Somero }\end{array}$ \\
\hline & & & E. rivala & $\begin{array}{l}\text { Arenito } \\
\text { Micucen }\end{array}$ & $\begin{array}{l}\text { Marino } \\
\text { Somere }\end{array}$ \\
\hline \multirow{2}{*}{395} & \multirow{3}{*}{ Ordoviciano } & \multirow{3}{*}{ Ca'acupe } & Tobctĩ & $\begin{array}{l}\text { Arenito } \\
\text { Sacaroidal }\end{array}$ & $\begin{array}{l}\text { Marino } \\
\text { Somere }\end{array}$ \\
\hline & & & Cerro Hũ & $\begin{array}{l}\text { Arenito } \\
\text { Arcosiano }\end{array}$ & Fluvial \\
\hline \multirow{2}{*}{435} & & & Paranuari & $\begin{array}{l}\text { Congiomerado } \\
\text { Drroougrts }\end{array}$ & Fluvial \\
\hline & Cambriano & $\begin{array}{c}\text { Suite } \\
\text { Ca'apucú }\end{array}$ & & $\begin{array}{l}\text { Manmatitas } \\
\text { Écidies }\end{array}$ & Volcánice \\
\hline
\end{tabular}

Figura 5 - Coluna estratigráfica da área de estudo, modificado de Paraguay (1986). 


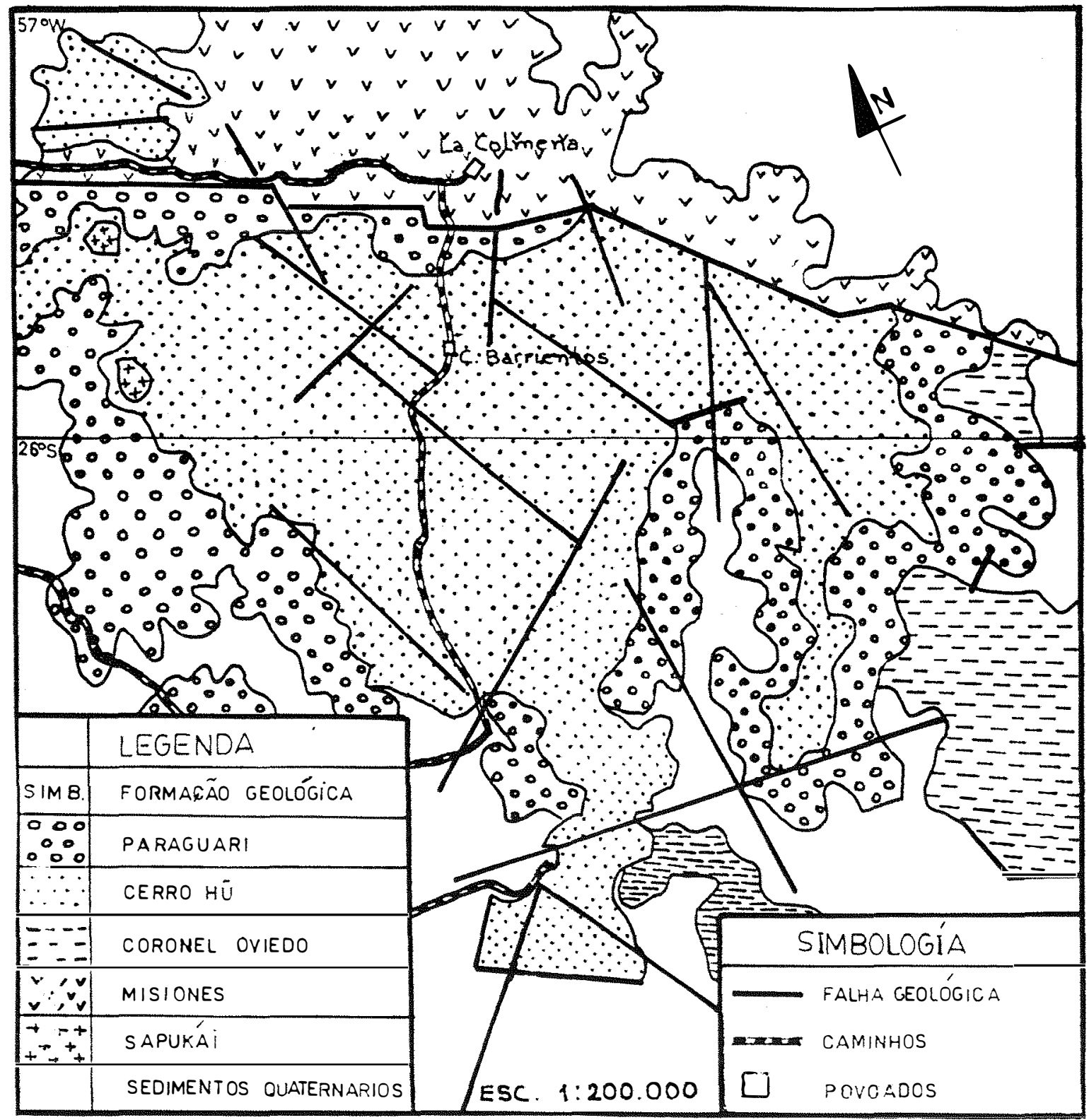

Figura 6 - Mapa geológico da área de "Cordillerita" (The Anschutz Corporation, 1981). 
corresponderiam a fase transgressiva do mar, não se havendo encontrado as formações correspondentes à fase regressiva, constituídas por arenitos com granulometria mais fina (Formações "Eusébio Ayala, Vargas Peña e Kari'y" do Grupo "Itakurubi")(Gómez, $\left.1995^{2}\right)$.

\subsubsection{Vegetação}

A vegetação original está constituída por uma floresta subtropical decídua e mesofítica (Hueck \& Seibert, 1988), a qual tem cerca de 250 espécies arbóreas constituindo três estratos.

$\mathrm{O}$ estrato dominante tem altura de $25-30 \mathrm{~m}$ e inclui principalmente as seguintes espécies: Astronium fraxinifolium, Tabebuia heptaphyla, Cordia trichotoma, Patagonula americana, Anadenanthera colubrina, Apuleia leiocarpa, Enterolobium contortisiliquum, Lonchocarpus leucanthus, Myrocarpus frondosus, Parapiptadenia rigida, Peltophorum dubium, Pterogyne nitens, Cedrela fissilis, Chlorophora tinctoria, Ficus enormis, Balfourodendrum riedelianum e Diatenopterix sorbifolia.

O estrato intermediário chega até $12-20 \mathrm{~m}$ de altura e consta de espécies mais perenifolias e com exigência intermediária de luz, sendo principalmente das famílias das lauraceas e mirtáceas, enquanto que o estrato inferior compreende espécies esciófitas com altura de 5-10 m e em nível do solo, encontram-se plantas herbáceas, principalmente samambaias, epífitas e cipós.

Nos lugares mais úmidos e perto dos córregos e rios, encontra-se uma floresta densa, com altura máxima de 15-20 m, com predomínio das espécies de Luehea divaricata, Sesbania sp., Ruprechtia laxifolia, Cupania vernalis e Croton urucurana.

\footnotetext{
2Gomez, D. 1995. Comunicação pessoal na Serra de "Cordilherita", Paraguai.
} 


\subsubsection{Solos}

Lopez et al. (1995) classificaram os solos avermelhados da Serra "Cordillerita" segundo o "Soil Taxonomy" como Rhodic Paleudalf (sic), os quais apresentam as seguintes características: textura franco-arenosa fina, derivado de arenito, declividade entre 4 e $15 \%$, bem drenados e sem rochosidade, capacidade de uso das terras III esf, terras com moderadas limitações que reduzem a seleçāo de culturas e precisam de práticas moderadas ou intensivas de manejo e conservação, devido ao risco de erosão (e) e baixa fertilidade (sf).

Os solos poucos profundos foram classificados pelos mesmos autores, como Lithic Udorthent e tem as seguintes características: textura franco-arenosa fina,

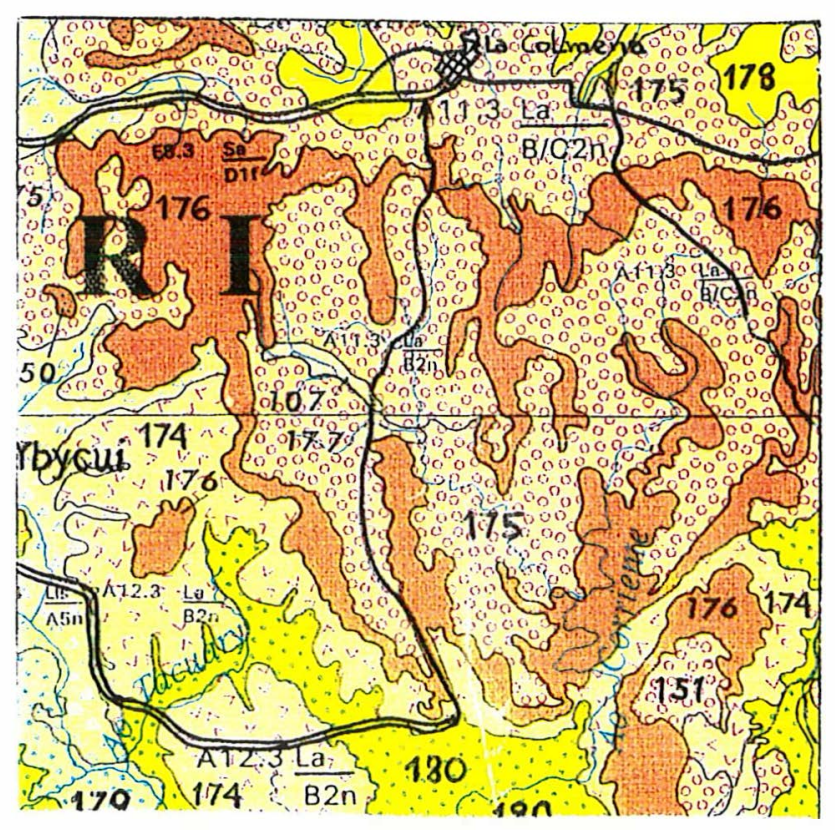

Esc. 1:500.000

\section{Legenda}

107 Terras Misceláneas

151 Rhodic Paleudalf

174 Mollic Paleudalf

175 Rhodic Paleudalf

176 Lithic Udorthent

177 Rhodic Paleudalf

178 Aquic Paleudalf

179 Typic Albaquult

180 Aquic Paleudult

Figura 7 - Mapa de solos da regiāo da Serra de "Cordillerita" (Lopez et al., 1995). 
derivado de arenito, deciividade maior que $15 \%$, drenagem excessiva e rochosidade forte, capacidade do uso das terras VIII esf, terras marginais não aptas para atividade agropecuária ou florestal que devem destinar-se à proteção da flora e fauna, captação de aquíferos e paisagismo, devido ao alto risco de erosão (e) e baixa fertilidade (sf).

Os solos das planícies de inundação foram agrupados por aqueles autores em uma unidade de mapeamento denominada Terras Miscelâneas, derivados de sedimentos aluviais, declividade de 0-3\%, drenagem moderada e sem rochosidade, capacidade de uso das terras $\mathrm{Vwd}$, terras com limitações devido a drenagem impedida e baixa permeabilidade (wd), aptas para pastagem (Figura 7).

\subsubsection{Hidrologia}

Os riachos e rios da serra são afluentes da margem direita do Rio "Tevikuary", o qual desemboca no Rio Paraguai, para conformar a grande Bacia do Prata. O curso principal constitui o Riacho "Corriente" que corre de NE para SO, que tem um padrão de drenagem subparalelo nas nascentes, devido ao relevo de "cuestas" destas áreas, mudando para retangular nos cursos médio e inferior (Figura 8).

O Riacho "Ybycu'i" que também corre de NE a SO, apresenta um típico padrão de drenagem subparalelo. A maioria dos cursos hídricos da serra possuem cachoeiras e quedas de águas, e a presença de rochas no leito é muito comum.

\subsubsection{Usos da terra}

Os seguintes usos da terra da da Serra "Cordillerita" podem ser observados na Figura 9, que mostra uma imagem satelitária do Landsat 5, tomada no dia 23.09.94: 


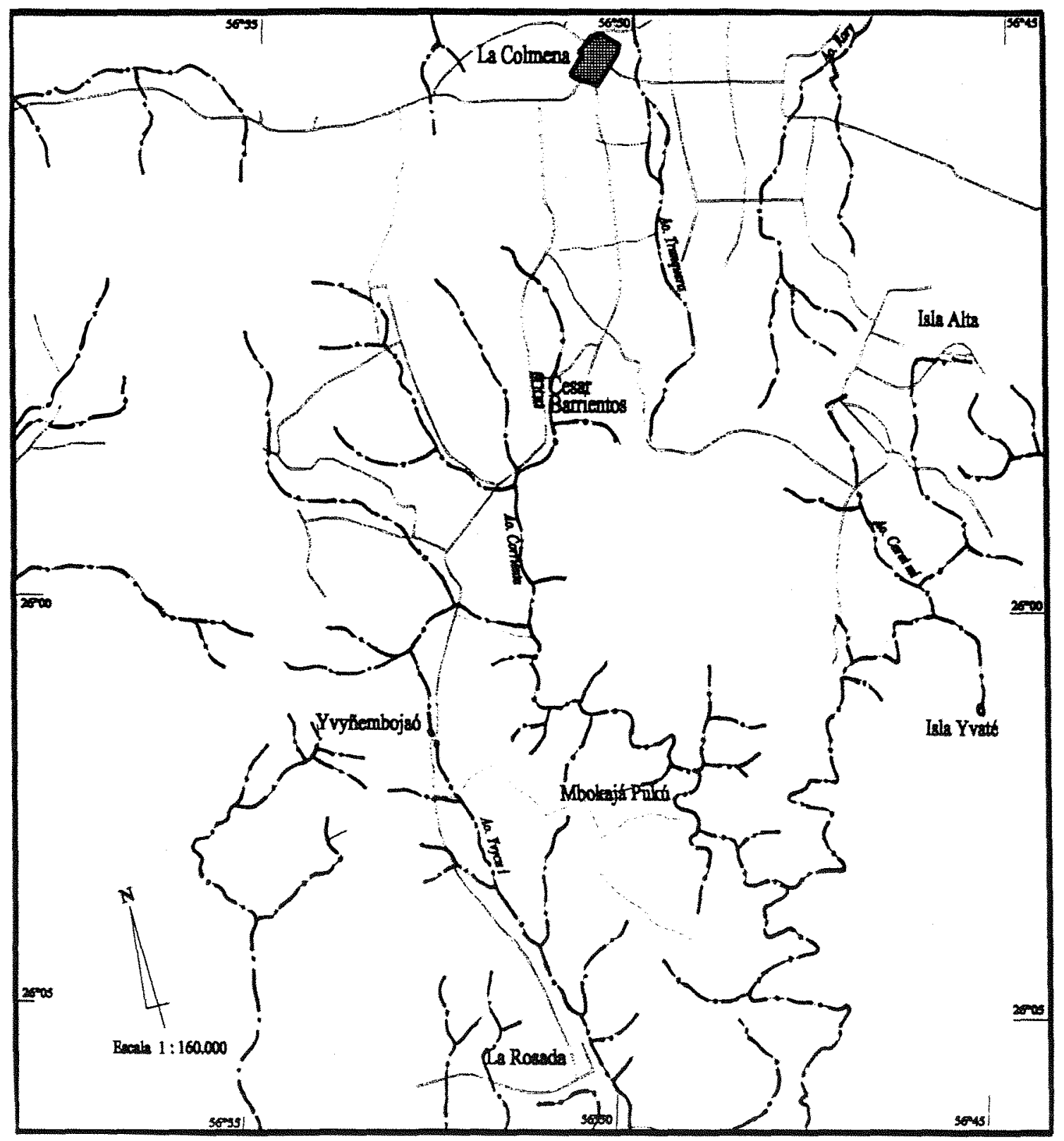

Figura 8 - Rede de drenagem na Serra de "Cordillerita", caminhos e povoados principais. 


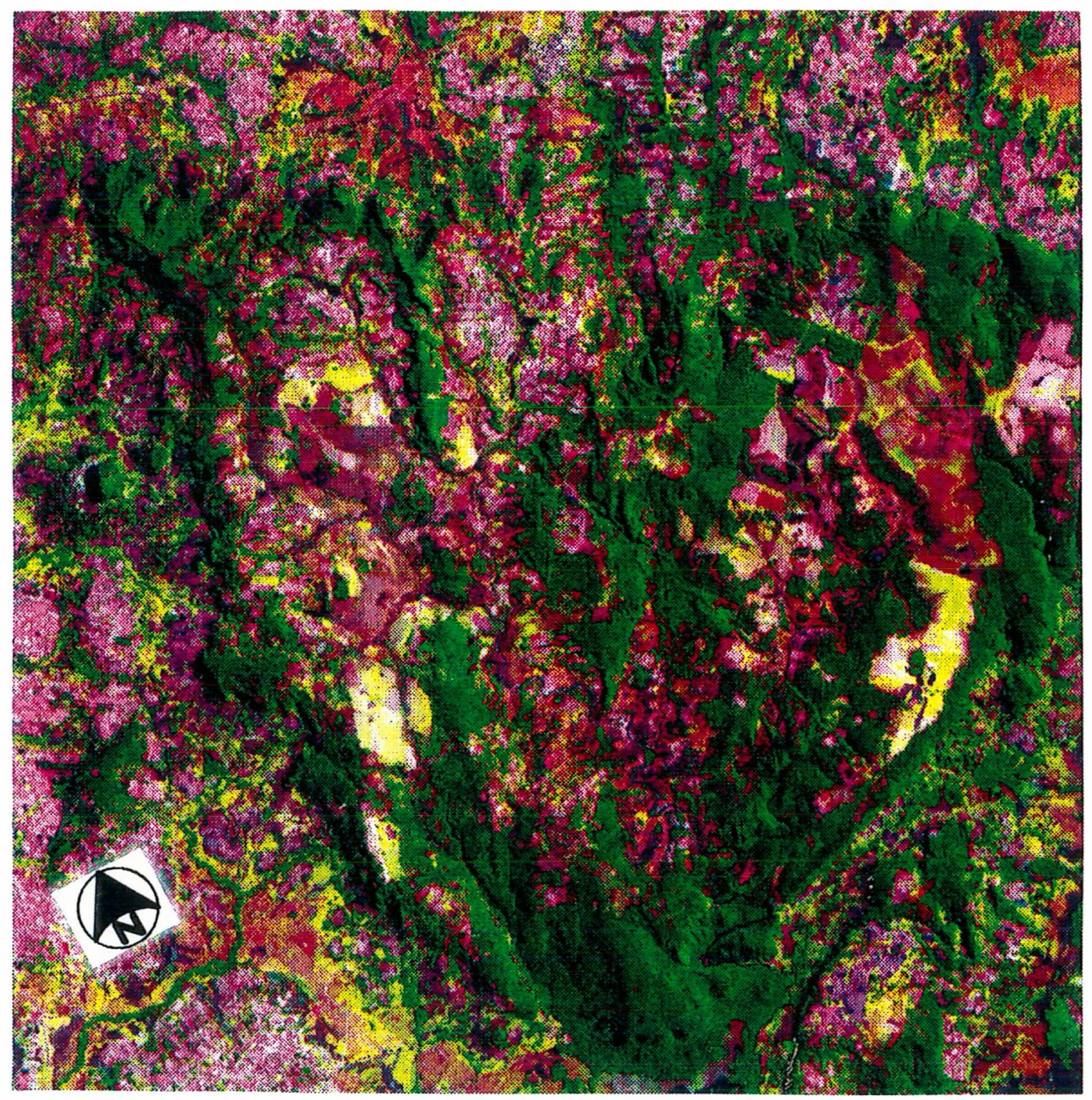

ESC. 1:170.000

Figura 9 - Imagem composta em falsa cor do satélite Landsat TM, bandas 3, 4 e 5, do dia 23.09.94 da Serra "Cordillerita". (Cores de tonalidade verde escura: mata nativa; verde clara: pastagem seca; roxo: pastagem úmida; vermelho: solo úmido; lilás: terra alagada). 
Uso urbano: representado pelos povoados de "La Colmena" e "César Barrientos".

Uso agrícola: os principais cultivos sao: milho, mandioca, alverja, feijão, abóbora, algodão e de cana-de-açúcar.

Uso pastoril: é o de maior importância econômica da área, havendo fazendas de médio porte (100-1000 ha), algumas para cria e engorda de boi e outras para leite.

Uso florestal: é praticamente extensivo e de exploração da mata nativa, principalmente para produção de lenha.

Uso recreativo/ambiental: representado por uma unidade de conservação, o Monumento Histórico Natural "Ybycu'i" (ex-Parque Nacional), no extremo Sul da serra.

\subsection{Trabalho de escritório}

\subsubsection{Mapeamento das unidades fisiográficas}

Com base nas cartas topográficas em escala 1:50.000 da Direção do Serviço Geográfico Militar (D.S.G.M.) e numa imagem composta em falsa cor das bandas 3, 4 e 5 do satélite "Landsat" do dia 23.09.94 em escala 1:100.000, foi selecionada uma área preliminar a ser estudada, de aproximadamente $625 \mathrm{~km}^{2}(25 \times 25$ $\mathrm{km})$, a qual abarca a maior parte da serra.

Utilizando-se fotografias aéreas pancromáticas em escala 1:50.000 do ano de 1965, separaram-se com ajuda de um estereoscópio de espelho, diferentes segmentos do relevo segundo critérios de tonalidade fotográfica, textura fotográfica, formas, padrão e principalmente quebra de declividade, delimitando-se as seguintes posições topográficas: 
Topo: cimeiras ou partes mais elevadas dos interflúvios, geralmente com declives de $0-5 \%$.

Escarpa: terreno íngrime com declives maiores que $30 \%$.

Vertente: terreno com declividade de 5-30\%.

Sopé: parte inferior de escarpas e encostas com declives de 20-30\%.

Patamar: terraços que curtam a continuidade das encostas e escarpas, com declives de $1-5 \%$.

Planície: áreas de inundação dos riachos, com declives de 1-3\%.

Com o fim de ter uma idéia geral da distribuição das formas do relevo, elaboraram-se vários perfís topográficos com direcionamento preferencial Leste-Oeste, dois perfís topográficos (A-B e B-C) no setor norte da serra, dois perfís (D-E e E-F) na parte media da serra e dois perfís (G-H e H-I) no setor sul da mesma (Figura 11).

$\mathrm{Na}$ elaboração do mapa geomórfico (Figura 10), utilizou-se uma aproximação fisiográfica (Goosen, 1961), a qual está baseada no conhecimento profundo dos processos fisiográficos dinâmicos de modelado da paisagem, na qual a análise geomórfica de cada terreno constitui o caminho básico, conformando-se oito unidades fisiográficas a seguir:

UNIDADE 1: colinas convexas (C.C.)

UNIDADE 2: colinas convexo-côncavas (C.C.C.)

UNIDADE 3: colinas convexo-côncavo-convexas (C.C.C.C.)

UNIDADE 4: colinas escalonadas (C.E.)

UNIDADE 5: morros testemunhos (M.T.)

UNIDADE 6: encostas convexo-côncavas de frente de falhas (E.C.C.F.F.)

UNIDADE 7: leques aluviais (L.A.)

UNIDADE 8: planícies aluviais (P.A.) 
Das oito unidades, foram estudadas em detalhes as três primeiras por causa da disponibilidade de tempo e assumindo que os processos dinâmicos das mesmas repetem-se na unidade 4 , enquanto que nas demais unidades $(5,6,7$ e 8 ) ocorrem outros processos geomórficos e pedológicos que requerirão estudos posteriores.

De cada unidade delimitada, elaborou-se um perfil topográfico com relação de escalas horizontal/vertical de 4:1, utilizando-se como base a carta topográfica em escala 1:50.000 ampliada a uma escala 1:20.000 com o fim de ter uma melhor visualização da forma das mesmas.

\subsubsection{Análises das informações}

Com os dados morfológicos dos solos, descritos em trincheiras escavadas no campo e com os resultados das análises de laboratório classificaram-se os solos segundo o Sistema Brasileiro de Classificação de Solos ( $2^{a}$ aproximação) preconizado por Camargo et al. (1987) e pela "Soil Taxonomy" (Soil Survey Staff, 1994).

A identificação dos argilominerais das frações argila e silte realizou-se, comparando-se os comportamentos dos picos de reflexão dos difratogramas de raio-X causados pelos diferentes tratamentos aplicados às amostras de solos.

O índice de desenvolvimento do perfil (IDP) de cada solo foi calculado segundo Harden (1982), com base nas seguintes informações morfológicas obtidas durante o trabalho de campo: a) Rubeificação; b) Textura total; c) Filmes de argila; d) Agregação; e) Consistência em seco; f) Consistência em úmido; g) Melanização, e h) $\mathrm{pH}$, com algumas modificações para adaptá-lo às descrições morfológicas deste trabalho, sendo as seguintes:

a) Rubeificação: A rubeificação (ou avermelhamento) dos horizontes foi quantificada comparando a cor (úmida) em relação à cor (úmida) do material de origem ou camada $\mathrm{Cr}$, outorgando-se 10 pontos por cada diferença que existe do matiz e do chroma. 
b) Textura total:_Quantificou-se outorgando 10 pontos a cada diferença de classe textural mais fina com relação à classe textural do material de origem subjacente (camada $\mathrm{Cr}$ ), mais 10 pontos por cada incremento de classe de pegajosidade e 10 pontos a cada incremento de classe de plasticidade, também com relação à pegajosidade e plasticidade da camada $\mathrm{Cr}$.

c) Filmes de argila: Outorgou-se 10 pontos a cada incremento de cerosidade do horizonte avalidado com relação ao material de origem, em termos de abundância, grau de desenvolvimento e localização dos filmes, e considerou-se um valor $=0$ para o material de origem.

d) Agregação: Outorgou-se 10 pontos a cada incremento na capacidade de agregação do horizonte avaliado em termos grau de desenvolvimento e tipo de agregado, com relação ao material de origem subjacente, considerando-se este sem agregação e com valor $=0$

e) Consistência em seco (dureza): Outorgou-se 10 pontos a cada incremento da classe de consistência em seco do horizonte avaliado com relação ao material de origem, considerado este sem consistência ou com valor $=0$.

f) Consistência em úmido: Outorgou-se 10 pontos a cada incremento de firmeza do horizonte avaliado com relação ao material de origem, considerado este com valor $=0$.

g) Melanização: Outorgou-se 10 pontos a cada diminuição do valor do horizonte A até $100 \mathrm{~cm}$ de profundidade, com relação ao material de origem, considerado este com valor $=0$.

h) $\mathrm{pH}$ : Outorgou-se 10 pontos a cada dezena do valor de $\mathrm{pH}$ diminuido do horizonte com relação ao pH do material de origem subjacente. 
Todos os valores calculados (passo 1) foram normalizados com o fim de poder compará-los, dividindo cada valor pelo valor máximo atingido na escala de cada atributo, obtendo-se assim uma escala que vai de 0 a 1 ou de 0 a $100 \%$ (passo 2); logo de cada horizonte foi somado os valores normalizados de cada atributo e dividido pelo total de atributos $(\mathrm{n}=8)$ para obter o índice de desenvolvimento do horizonte (passo 3), multiplicando-se pela espessura do horizonte em $\mathrm{cm}$ (passo 4 ) e finalmente somados todos os índices-cm de todos os horizontes (passo 5) para se obter o índice de desenvolvimento do perfil do solo (IDP).

\subsection{Trabalho a campo}

Realizou-se primeiro um reconhecimento a campo, percorrendo a área pelos principais caminhos e fazendo observações das seguintes características da paisagem: a declividade, a forma topografia, a vegetação, os solos e materiais de origem. Estes últimos foram observados principalmente em cortes de estradas e outras escavações realizadas para extração de materiais de terra a serem utilizadas na construção.

Dependendo da acessibilidade e, com ajuda das fotos aéreas selecionaramse sete toposeqüências preliminares localizadas em vertentes das colinas com diferentes formas topográficas, com o fim de realizar um estudo preliminar das caraterísticas dos solos e do relevo, observando-se em cada toposeqüência as seguintes características:

- comprimento, direção e grau do declive com clinômetro manual

- vegetação e uso da terra

- rochosidade e pedregosidade

- textura do solo a diferentes profundidades

- cor dos horizontes e camadas do solo

- transição aproximada entre os horizontes e camadas observadas 
De cada solo diferente encontrado e para representar as diferentes declividades e posições das sete toposeqüências preliminares, amostrou-se o horizonte superficial e o subsuperficial para serem analisados no laboratório.

Após o agrupamento das toposeqüências, segundo a morfologia dos seus perfís, foram selecionadas quatro toposeqüências representativas de três unidades fisiográficas (colinas convexas, colinas convexo-côncavas e colinas convexo-côncavoconvexas) para serem estudadas com maior detalhe, sendo as seguintes:

- Toposeqüência Convexa

- Toposeqüência Convexo-linear

- Toposeqüência Convexo-côncava

- Toposeqüência Convexo-Côncavo-Convexa

Em cada toposeqüência selecionada marcaram-se os lugares a serem escavadas as trincheiras para observação e amostragem pormenorizada dos solos, o que foi possível após uma inspeção com trado de toda a toposeqüência.

As trincheiras foram escavadas nas seguintes dimensões: $1 \mathrm{~m}$ de largura por $2 \mathrm{~m}$ de comprimento, como mínimo, e uma profundidade até atingir o lençol freático, rocha ou sedimento difícil de cortar com a pá, totalizando 15 trincheiras descritas e amostradas para o estudo pormenorizado.

A inspeção do perfil do solo em cada trincheira foi feito por comparação das características de cor, textura, agregação, consistência, cerosidade e desenvolvimento das raízes para a separação dos diversos horizontes, cuja denominação seguiu-se a nomenclatura de horizontes de solos proposta pela EMBRAPA (Embrapa, 1988).

Para a descrição geral e morfológica dos perfis de solos, utilizou-se as normas preconizadas pela Sociedade Brasileira de Ciência do Solo no Manual de Descrição e Coleta de Solos no Campo (Lemos \& Santos, 1984). 
Para fins de análise no laboratório foram tomadas vários tipos de amostras de material de solo, correspondentes aos diferentes horizontes e camadas, principalmente as seguintes:

- Amostras deformadas para análises físico-químicas e mineralógicas.

. Amostras indeformadas em anéis de $100 \mathrm{~cm}^{3}$ para determinação da densidade do solo e da partícula.

- Amostras indeformadas em caixinhas de cartão $6 \times 8 \times 4 \mathrm{~cm}$ para estudos micromórficos em lâminas delgadas.

Após a obtenção dos resultados de laboratórios foram realizadas outras viagens para conferir as idéias e hipóteses de trabalho, assim como para checagem de processos de morfogênese e pedogênese em lugares não visitados anteriormente.

\subsection{Análises de laboratório}

Nas amostras de terra coletadas com trado dos perfís de solos nas sete toposeqüências preliminares, foram realizadas as seguintes análises de rotina.

Separação das fraçōes grossas $(2-20 \mathrm{~mm})$ por destorroamento com rolo de madeira sobre uma chapa de borracha de $2 \mathrm{~cm}$ de espessura e peneiramento para obter as fraçōes de cascalho grosso $(7,5-20 \mathrm{~mm})$, cascalho fino $(2-7,5 \mathrm{~mm})$ e terra fina seca ao ar $(<2 \mathrm{~mm})$.

Granulometria pelo método do densímetro modificado pelo IAC (Camargo et al., 1986) e separação em 5 frações de areias: areia muito grossa (1-2 mm); areia grossa $(0,5-1,0 \mathrm{~mm})$; areia média $(0,250-0,500 \mathrm{~mm})$; areia fina $(0,105-0,250 \mathrm{~mm})$; areia muito fina $(0,05-0,105 \mathrm{~mm})$; silte $(0,002-0,05 \mathrm{~mm})$ e argila $(<0,002 \mathrm{~mm})$.

As análises químicas realizadas foram: $\mathrm{pH}$ em água e $\mathrm{pH}$ em $\mathrm{KCl}$ com potenciômetro de eletrodos (relação solo:água 1:2,5); matéria orgânica pelo método de oxidação úmida do Carbono orgânico (Walkeley \& Black, 1934) e multiplicação pelo 
fator 1,74; fósforo assimilável pelo método da resina trocadora de ânions; cátions trocáveis extraídos pela solução de $\mathrm{HCl}+\mathrm{NH}_{4} \mathrm{Cl}$ e quantificação de $\mathrm{Ca}^{++}, \mathrm{Mg}^{++}, \mathrm{K}^{+}$ e $\mathrm{Na}^{+}$com aparelho de absorção atômica; $\mathrm{H}^{+}+\mathrm{Al}^{++}$pelo método de titulação (Camargo et al., 1986).

Nas amostras obtidas dos 15 solos foram realizadas além das análises anteriores, as seguintes: densidade do solo e da partícula pelos métodos do anel volumétrico de $100 \mathrm{~cm}^{3}$ e do álcool etílico, respectivamente; argila dispersa em água pelo método do hidrômetro.

Análise micromorfológica das lâminas delgadas com microscópio ótico, preparadas a partir de amostras indeformadas impregnadas a vácuo com uma mistura 1:1 de resina e monômero de estireno mais 3 gotas de Peroxol.

Espectometria de raios- $X$ de alguns horizontes para caracterização mineralógica dos solos, após a eliminação da matéria-orgânica e prévio tratamento para eliminação de ferro pelo método de citrato-ditionito-bicarbonato (Jackson, 1969), e saturadas com potássio e magnésio, as amostras saturadas com $\mathrm{K}$ foram aquecidas a $350^{\circ} \mathrm{C}$ e $550^{\circ} \mathrm{C}$ e as saturadas com $\mathrm{Mg}$ também foram tratadas com glicol.

Ataque com $\mathrm{H}_{2} \mathrm{SO}_{4}$ para determinação de $\mathrm{SiO}_{2}, \mathrm{Al}_{2} \mathrm{O}_{3}, \mathrm{Fe}_{2} \mathrm{O}_{3}, \mathrm{TiO}_{2}$ e $\mathrm{MnO}$, de alguns horizontes e camadas.

Fluorescência do raio-X da fração areia fina de todos horizontes e camadas, após moagem em aparelho de ágata e preparo da pasta com pressão de 25 ton $/ \mathrm{cm}^{2}$.

Identificação dos minerais intemperizáveis da fração areia fina com o microscópio ótico, após separação das mesmas em leves e pesados, pelo método do bromofórmio e dos magnéticos com um imã e montadas em lâminas com bálsamo do Canadá. 


\section{RESULTADOS E DISCUSSÃO}

\subsection{Fisiografia}

A serra da "Cordillerita" constitui uma meseta conformada por estratos inclinados (estrutura monoclinal) com direção Noroeste-Sudeste, apresentando um relevo de "cuestas" interrompido por blocos monoclinais.

Na Figura 10 é apresentado o mapa resultante do agrupamento das unidades fisiográficas delimitadas com aerofotointerpretação e na Figura 11, três perfís topográficos cortando a serra com direção preferencial Leste-Oeste, que mostram a distribuição da forma do relevo e as fraturas e falhamentos. Os estratos inclinados estão conformados pelas formações geológicas do Grupo "Ca'acupe", constituídas pelo conglomerado basal (Formação "Paraguari"), pelo arenito arcosiano (Formação "Cerro hu") e pelo arenito sacaroidal (Formação "Tobati"), havendo-se encontrado uma inclinação de mais ou menos $6^{\circ}$ com direção SSE.

A morfoestrutura compreende "horsts" e "grabens", com degraus que se alternam em toda a serra. O "horst" principal encontra-se no centro da serra, com o pico máximo localizado no Morro Mongelos, com encostas e degraus que descem até os riachos "Corriente", "Pindo" e "Karaimi" (Figura 11b). Outro "horst" importante situa-se no lado Oeste da serra, com uma orientação Norte-Sul, que vai desde os Morros "Apyragua" e "Achon", no extremo Noroeste, até as colinas situadas no setor de "Limpio" e "Mbokaja puku" no extremo sul, com encostas que descem até os riachos "Sanja hu", "Takuary", "Corriente" e "Ybycu'i" (Figura 11a,d). 


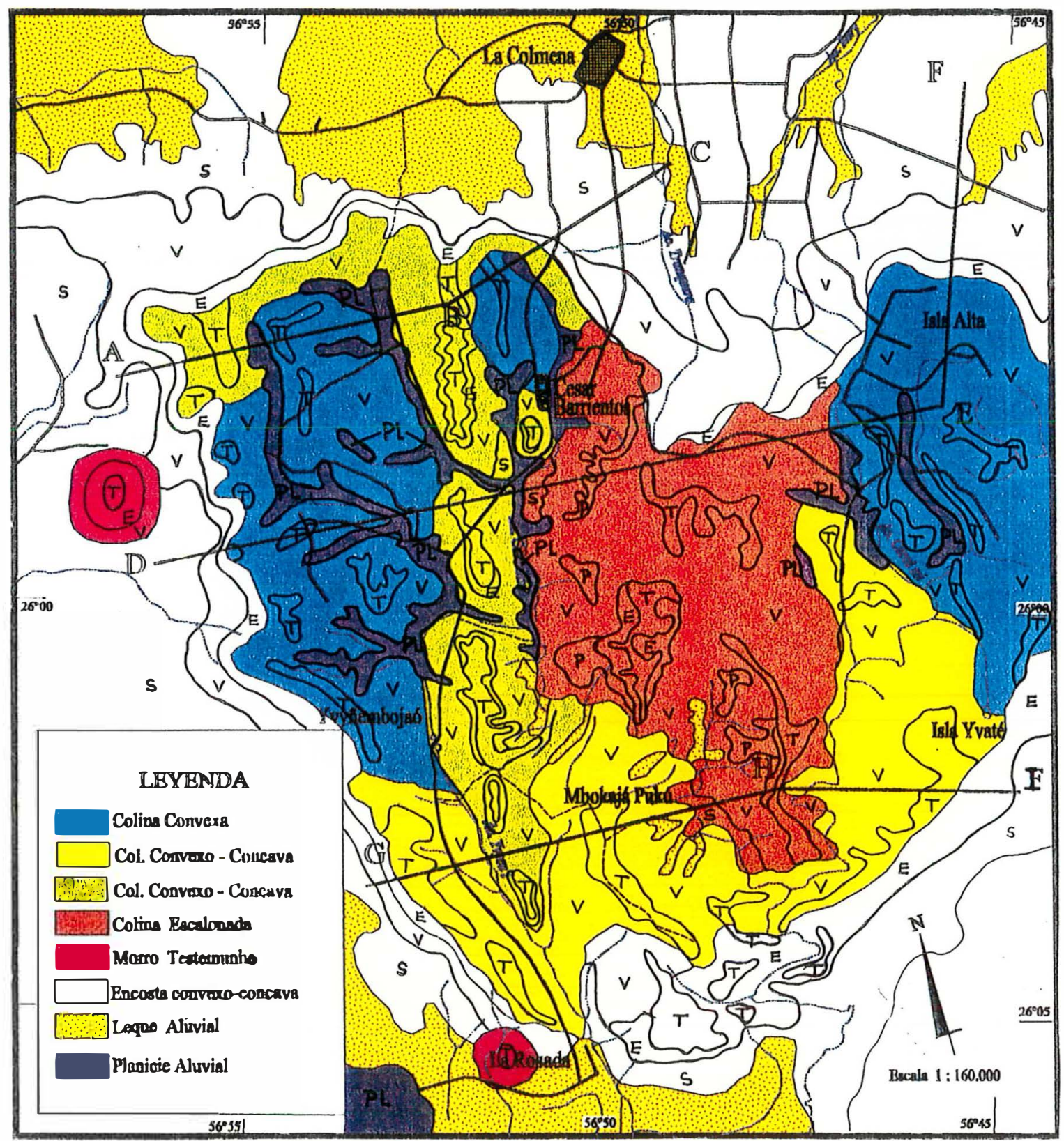

Figura 10 - Principais unidades fisiográficas da Serra de "Cordillerita" delimitadas com base na interpretação de fotos aéreas pancromáticas em escala 1:50.000 do ano de 1965 e posição dos perfís topográficos (A-B, B-C, D-E, E-F, G-H e H-I). T: topo; E: escarpa; V: vertente; P: patamar; S: sopé; Pl: planície. 
Um terceiro "horst" constitui o "plateau" de "Isla Yvate" localizado no setor Sudeste da serra, com orientação Noroeste-Sudeste e com encostas que se prolongam até os riachos "Karaimi" e "Cristal" (Figura $1 \mathrm{lc}$,d). Os "grabens" encontram-se distribuídos entre os principais "horsts" e servem de acomodação aos principais córregos e da serra.

As principais unidades fisiográficas delimitadas são as seguintes: a) colinas convexas (c.c.); b) colinas convexo-côncavas (c.c.c.); c) colinas convexocôncavo-convexas (c.c.c.c.); d) colinas escalonadas (c.e.); e) morros testemunhos (m.t.); f) encostas convexo-côncavas de frente de falha (e.c.c.); g) leques aluviais (l.a.) e h) planícies aluviais (p.a.) (Figura 10). A diferença de altura da serra é de $410 \mathrm{~m}$, indo desde 150 m.s.n.m. nas planícies aluviais que bordeiam a serra até $559 \mathrm{~m}$ no Morro "San José" (morro testemunho), sendo que as diferentes colinas têm alturas que variam de 250 a 500 m.s.n.m.

As encostas convexo-côncavas de frente de falhas rodeiam quase toda a serra e os morros testemunhos encontram-se localizados no setor Norte e Oeste. Os leques aluviais predominam no setor Norte da serra e em alguns vales interiores no setor Centro-Sul, enquanto que as planícies aluviais predominam no setor Nordeste.

Os principais processos que atuaram na esculturação das colinas são: a erosão (Figura 12 a); os movimentos lentos de massa, principalmente o rastejamento (Figura 12 b); o desmoronamento e o fluxo lateral da água de infiltração, enquanto que os morros testemunhos e as escostas convexo-côncavas de frente de falha foram modelados pela erosão e deposição de sedimentos coluviais, assim como pelos movimentos rápidos de massa (fluxo de terra e lama, desmoronamento), estes últimos responsáveis também pela conformação dos leques aluviais, processos considerados degradacionais por produzirem superfícies preferentemente erosionais (Daniels \& Hammer, 1992).

Por outro lado, os leques e as planícies aluviais são superfícies deposicionais, produzidos por processos considerados agradacionais (ou construcionais), principalmente deposição de materiais de terra causadas pela água dos cursos hídricos. 


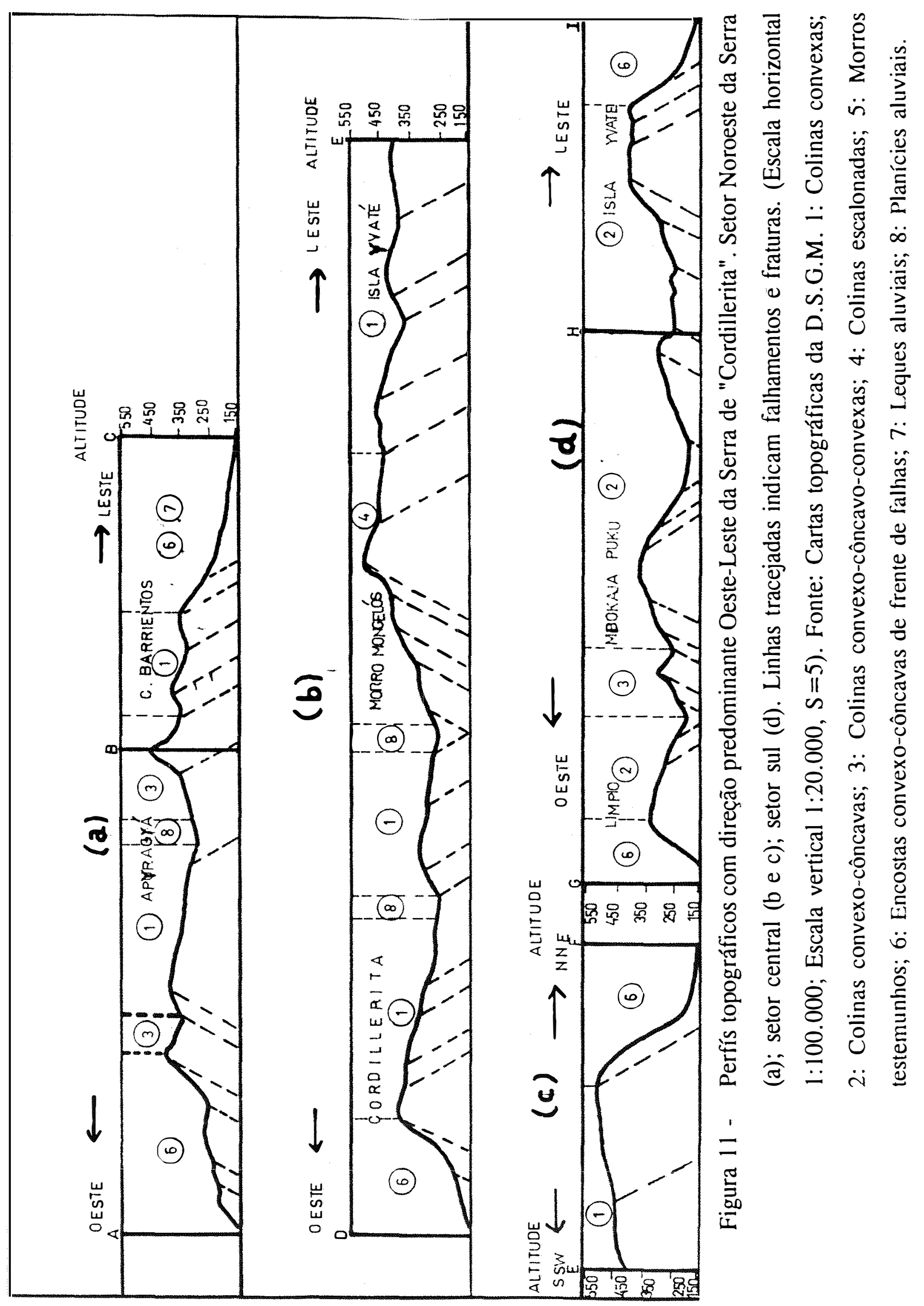


a.
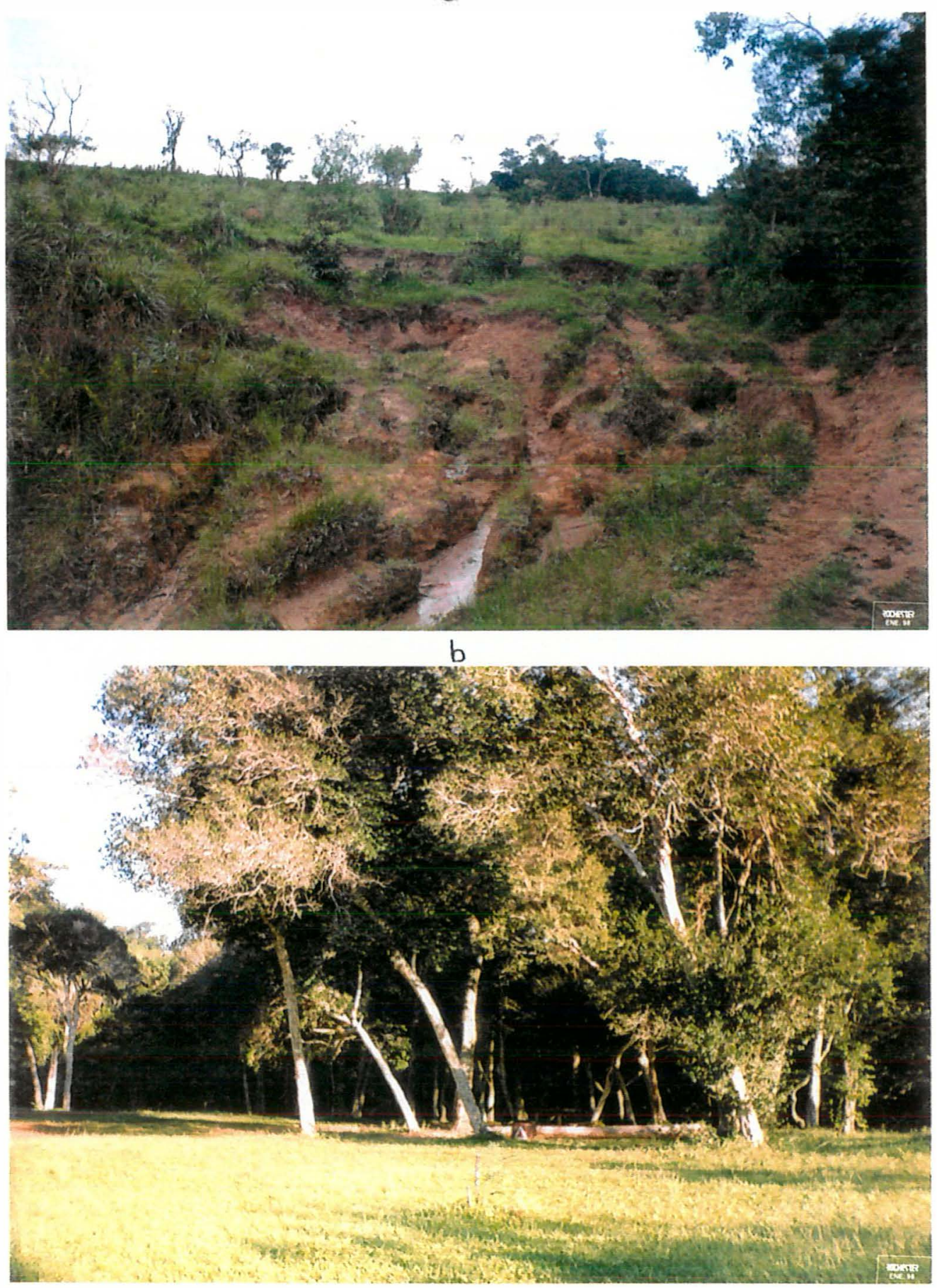

Figura 12 - Processos geomórficos observados na maioria das colinas da serra: a) sulcos de erosão; b) árvores inclindas com relação à vertical por causa do rastejamento. 


\subsubsection{Colinas convexas (c.c.)}

Estas colinas encontram-se localizadas em três áreas da serra: uma localiza-se entre a cimeira do lado Oeste da serra entre os riachos "Corriente", "Horqueta" e "Ybycu'i", com cotas que vão desde 250 m até 445 m.s.n.m., esta última encontra-se no Morro Sauce. Outra área menor encontra-se na parte Norte da serra, entre dois nascentes do Riacho "Corriente" e antes de chegar ao Povoado de Cesar Barrientos, com cotas compreendidas entre 300 e 380 m.s.n.m. Uma terceira área ocupa um amplo setor no extremo Noreste da serra, conhecido como "Isla Yvaté", entre as nascentes dos Riachos "Caraimi" e "Cristal" e com cotas compreendidas entre 300 e 516 m.s.n.m., esta última localizada no Morro "Mbokaja" (Figura 11). As rochas são predominantemente arenitos arcosianos.

Na Figura 13a pode-se observar uma vista geral da paisagem das colinas convexas, as quais são ligeiramente dissecadas e na Figura 13b, um perfil topográfico representativo da mesma.

O relevo é geralmente ondulado com declives que vão desde 1 até $15 \%$, dependendo da posição topográfica. Assim, os topos são planos, estreitos e alongados, com declives que variam entre 1 e $3 \%$, comprimento de rampa variando desde 20 até $100 \mathrm{~m}$, passando gradualmente para um declive de forma linear ligeiramente convexo de 5 a $10 \%$ e comprimento que varia de 300 a $2000 \mathrm{~m}$, a qual pode ter uma quebra do relevo mais acentuada no terço inferior da colina, onde o declive pode chegar até 15$15 \%$ com rampas curtas de 50-100 m.

Os segmentos topográficos identificáveis nas fotos aéreas são: o terço superior (topo); o terço médio e o terço inferior, havendo um limite gradual entre os mesmos por ter uma convexidade suave e pela ausência de quebras abruptas do declive, assim como alguns patamares pouco expressivos em algumas partes. 
a

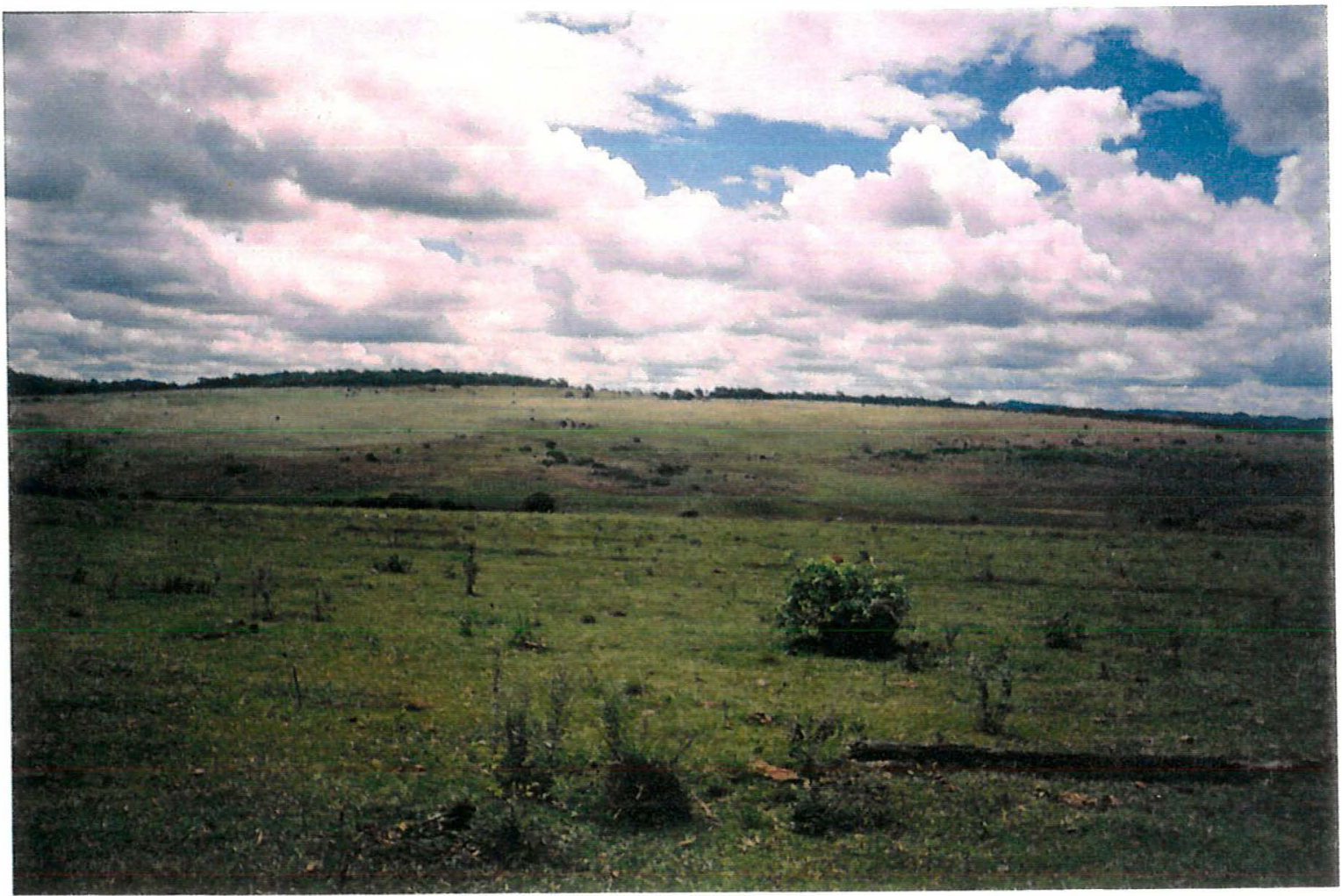

b

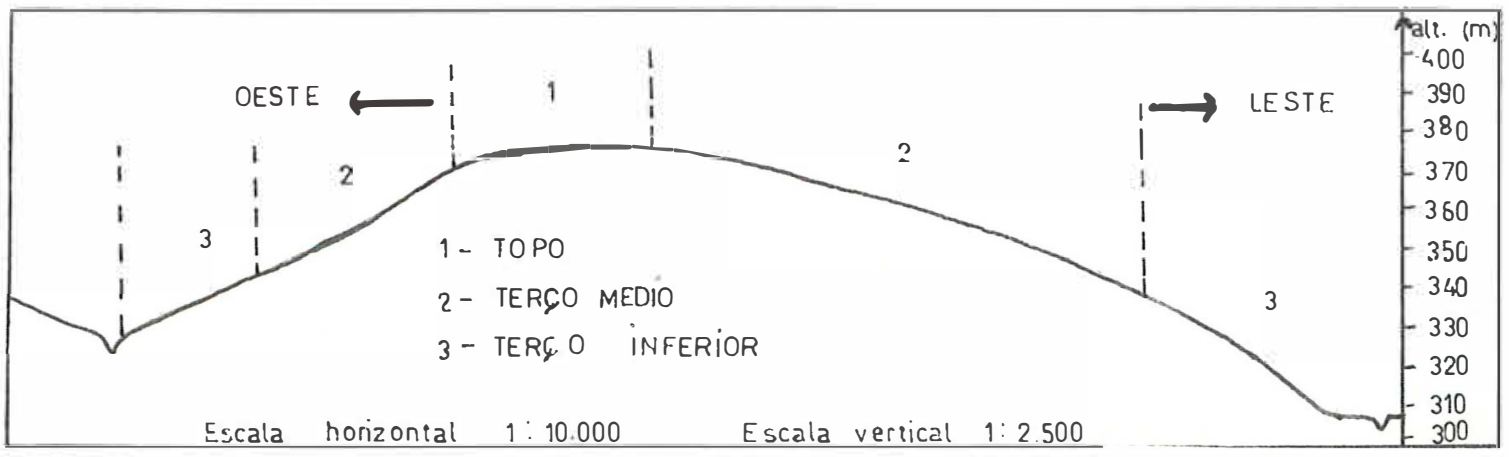

Figura 13 - Paisagem típica das colinas convexas (a); e perfil topográfico representativo com relação de escalas $S=4$ (b). 
Pode-se observar diferenças importantes quanto à forma, declividade, comprimento do declive, solos e grau de erosão, entre as vertentes. Dependendo da orientaçāo das mesmas, as rampas com orientaçāo Oeste tem uma forma linear e são mais curtas que as de orientação Leste, com declividade que podem chegar até $10 \%$, solos vermelhos-amarelos a brunos-escuros, de textura média ao longo do perfil e com pouco gradiente textural. As rampas com orientação Leste, por sua vez, apresentam forma ligeiramente convexa, com declives que podem chegar até $15 \%$ e maior comprimento, solos vermelhos-escuros de textura médio/argilosa com moderado gradiente textural, enquanto que na encosta com orientaçāo Sul, a forma se aproxima a uma leve escada com declives inferiores a $8 \%$, comprimentos de até $3000 \mathrm{~m}$ e solos muito variáveis em termos de cor e profundidade.

Os topos estão constituidos por solos com pouca profundidade que variam de rasos à pouco profundos $(0,3 \mathrm{a}, 0,6 \mathrm{~m})$ e outros moderadamente profundos $(0,8$ a 1 $\mathrm{m})$; e nas vertentes ocorrem solos vermelhos amarelos profundos $(2 \mathrm{~m})$ de textura média a argilosa, encontrando-se camadas lateríticas de diferente espessura em algumas posições do relevo, principalmente nas encostas com orientação Oeste.

A vegetação original é a floresta subtropical subperenifólia, a qual apresenta uma maior altura no terço médio e inferior das colinas, geralmente de 25 a $30 \mathrm{~m}$, diminuindo nos topos onde a altura chega ao máximo de $10 \mathrm{~m}$.

$\mathrm{O}$ uso da terra encontra-se mais ou menos adaptado ao potencial produtivo, predominando o uso agrícola nos solos vermelhos-amarelos profundos de textura média/argilosa, pastoreio extensivo nos solos moderadamente profundos de textura média e nos solos profundos de textura média, assim como uso florestal de exploraçāo nos solos pouco profundos.

A erosāo observada foi a do tipo laminar e forte no terço superior, em sulcos em grau moderado nas rampas curtas com orientaçāo Oeste e em sulcos em grau forte nas rampas com orientação Leste, ocorrendo até voçorocas que recuam nas surgentes e cabeceiras das nascentes dos riachos (ravinamento). 


\subsubsection{Colinas convexo-côncavas (c.c.)}

Estas colinas encontram-se situadas no setor Sul da serra, nos locais denominados "Limpio", "Mbokaja puku" e "Isla Yvaté", com cotas que variam desde 150 até 436 m.s.n.m., esta última altura em "Isla Yvaté", com encostas que descem até os Riachos "Ybycu'i", "Corriente" e "Caraimi" (Figura 11). As rochas são arenitos arcosianos.

Na Figura 14 pode-se observar a paisagem típica destas colinas (Figura 14a) e um perfil topográfico representativo das mesmas (Figura 14b).

O relevo é fortemente ondulado com declives que variam de 1 a $5 \%$ nos topos, lançantes curtas com 100-200 m, passando para declives de 6 a $10 \%$ no terço médio com 500-1000 m de comprimento, e de até 15-30\% em alguns setores como perto das surgentes hídricas localizadas na base da Colina de "Limpio". Em algumas vertentes e no terço inferior, o declive muda para 3 a $5 \%$ suavizando o relevo e conformando um perfil convexo-côncavo, com um sopé coluvial que grada para sedimentos aluviais perto dos cursos hídricos.

Os segmentos topográficos identificáveis nas fotos aéreas são: o terço superior (topo), o terço médio e o terço inferior, com quebras do relevo pouco acentuadas, sopé interdigitado com pequenas planícies aluviais e pequenos leques aluviais em alguns setores situados perto do córrego "Corriente".

Existem diferenças entre as vertentes com orientação Leste e Oeste, podendo se observar em algumas, a presença de pequenos leques aluviais na vertente Leste, como os da Colina de "Mbokaja puku" que chegam até o curso do Riacho "Corriente", assim como sedimentos coluviais em alguns setores do terço inferior.

Nos topos predominam solos vermelhos amarelos profundos $(2 \mathrm{~m})$, de textura médio/argilosa com moderado gradiente textural e presença de camada concressionária laterítica no limite solum/alterita, passando para solos poucos profundos a moderadamente profundos $(0,5-0,8 \mathrm{~m})$, vermelhos-amarelos e vermelhos escuros, de 
a

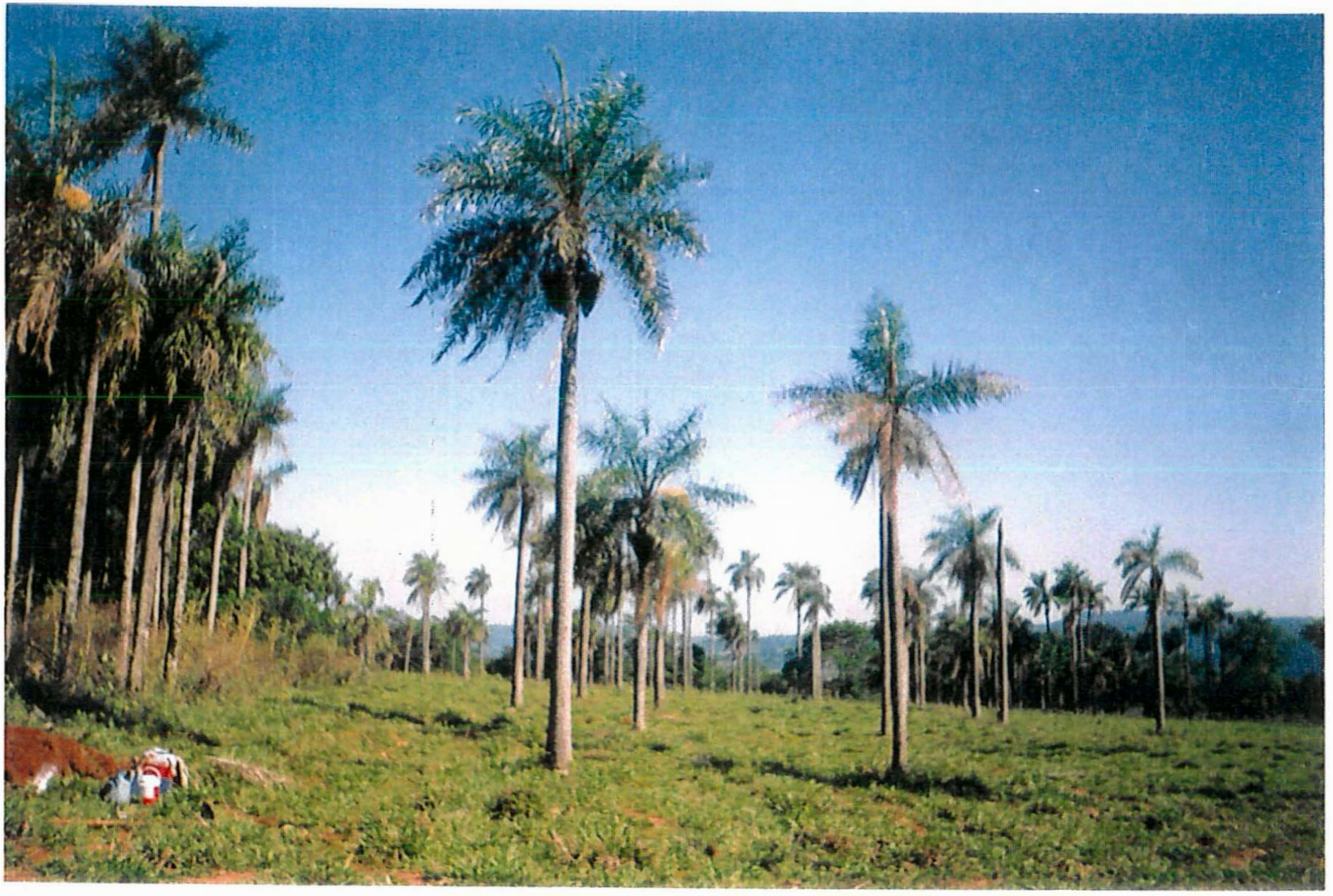

b

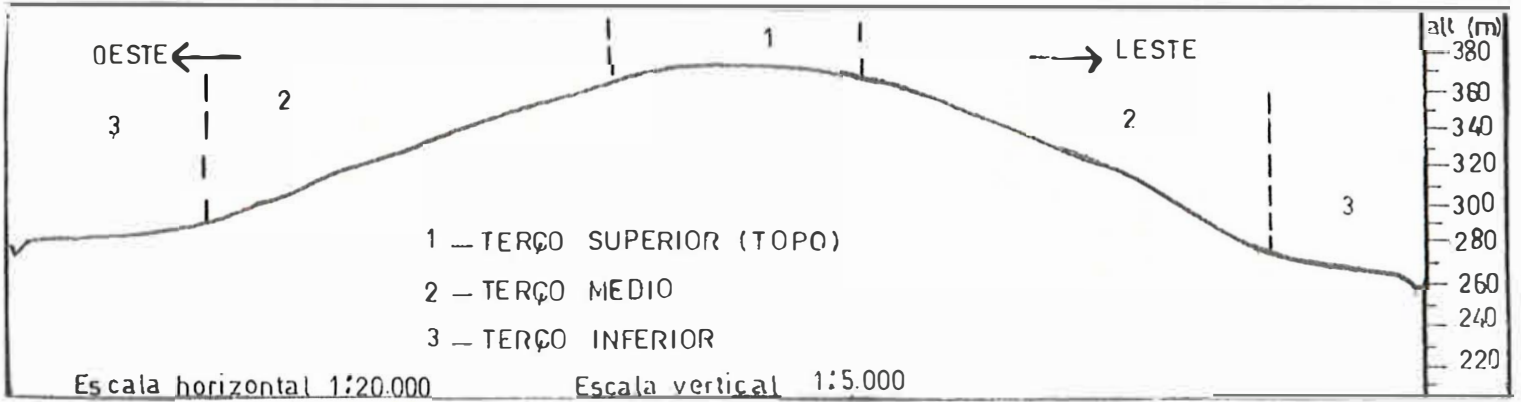

Figura 14 - Paisagem do terço médio das colinas convexo-côncavas (a) e perfil topográfico representativo da Colina de "Mbokaja puku" com relação de escalas $S=4(b)$. 
textura média e com pouco gradiente textural no terço médio da encosta e solos arenosos profundos a muito profundos $(>2 \mathrm{~m})$, brunos amareladas no terço inferior (sopés).

A vegetação original é também a floresta subtropical subperenifólia, a qual apresenta maior altura onde solos são mais profundos. Nos sopés perto dos cursos hídricos, predomina a floresta subtropical higrófila de várzea alternada com o campo subtropical hidrófilo de várzea. O uso da terra é predominantemente pastoreio intensivo nos topos, pastoreio extensivo e florestal de exploração nas encostas médias e florestal de exploração e recreativo nos sopés.

Nestas colinas foram observados alguns processos que possivelmente atuaram na modelagem, como rastejamento (evidenciado pela inclinação das árvores com relação à vertical) e erosão nos terços superior e médio, deposição coluvial nos sopés, suspensão temporária do lençol freático entre o solum e a alterita (camada $\mathrm{Cr}$ ), assim como evidências de alguns movimentos rápidos de massa (fluxo de terra e lama) que originaram pequenos leques aluviais.

\subsubsection{Colinas convexo-côncavo-convexas (c.c-c-c.)}

Estas colinas encontram-se localizadas em uma faixa com orientação Norte-Sul, desde os morros de "Achon" e "Apyragua" no setor Noroeste da serra até as nascentes do Riacho "Ybycu'i" no lugar denominado "Yvyñemboja'o", com alturas que variam de 200 a 500 m.s.n.m., esta última localizada em "Apyragua" (Figura 11), predominando também na mesma rocha o arenito arcosiano. Na Figura 15a mostra-se a paisagem típica destas colinas e na Figura 15b, um perfil topográfico representativo.

O relevo é fortemente ondulado nos topos (cristas) das colinas, onde o declive varia de $1-3 \%$, aumentando até $30 \%$ na encosta superior, passando para moderadamente ondulado nas encostas médias, com declive que varia de 6-8\% e rampas 
de 500-1000 m, sendo que na encosta inferior o declive é de $12-15 \%$ e tendo comprimentos curtos de $50 \mathrm{~m}$.

$\mathrm{Na}$ encosta superior observou-se grande quantidade de pedregosidade de tamanho variável e com predomínio de matacōes, o que pode ter sido resultado de movimentos rápidos de massa (desmoronamento) em épocas passadas, já que hoje estas encostas estāo estabilizadas pela vegetaçāo florestal.

Os segmentos topográficos identificáveis nas fotos aéreas são: o tôpo, a encosta superior, a encosta média e a encosta inferior, tendo todos eles uma quebra acentuada do relevo. Em alguns setores da encosta superior e acima da concavidade, pode-se observar uma pequena escarpa com direção predominante Norte-Sul.

No topo destas colinas ocorrem solos com variada profundidade, desde rasos ou pouco profundos $(0,3$ a $0,6 \mathrm{~m})$, brunos-amarelados de textura areia franca, passando para muito rasos $(<0,3 \mathrm{~m})$, brunos-amarelados de textura areia franca nas encostas superiores onde há afloramentos rochosos e pedregosidade em grau forte.

Nas concavidades ocorrem solos vermelhos-amarelos muito profundos (2$3 \mathrm{~m}$ ), de textura areia/média, com presença de um horizonte $\mathrm{E}$ álbico, ocorrendo geralmente nas encostas médias solos profundos à muito profundos (2-4 m), vermelhosescuros, de textura média/argilosa que gradam para solos pouco profundos $(0,5 \mathrm{~m})$, vermelhos-escuros, de textura argilosa, nas quebras de relevo localizadas entre a encosta média e a encosta inferior, com presença de camadas concrecionárias lateríticas em nível do contato entre o "solum" e a alterita.

$\mathrm{Na}$ encosta inferior, o solo volta a ser mais profundo $(1,5-2,0 \mathrm{~m})$, também vermelho-amarelo de textura argilosa com presença de uma camada concressionária de maior profundidade e de maior espessura que a do solo situado na convexidade. 
a

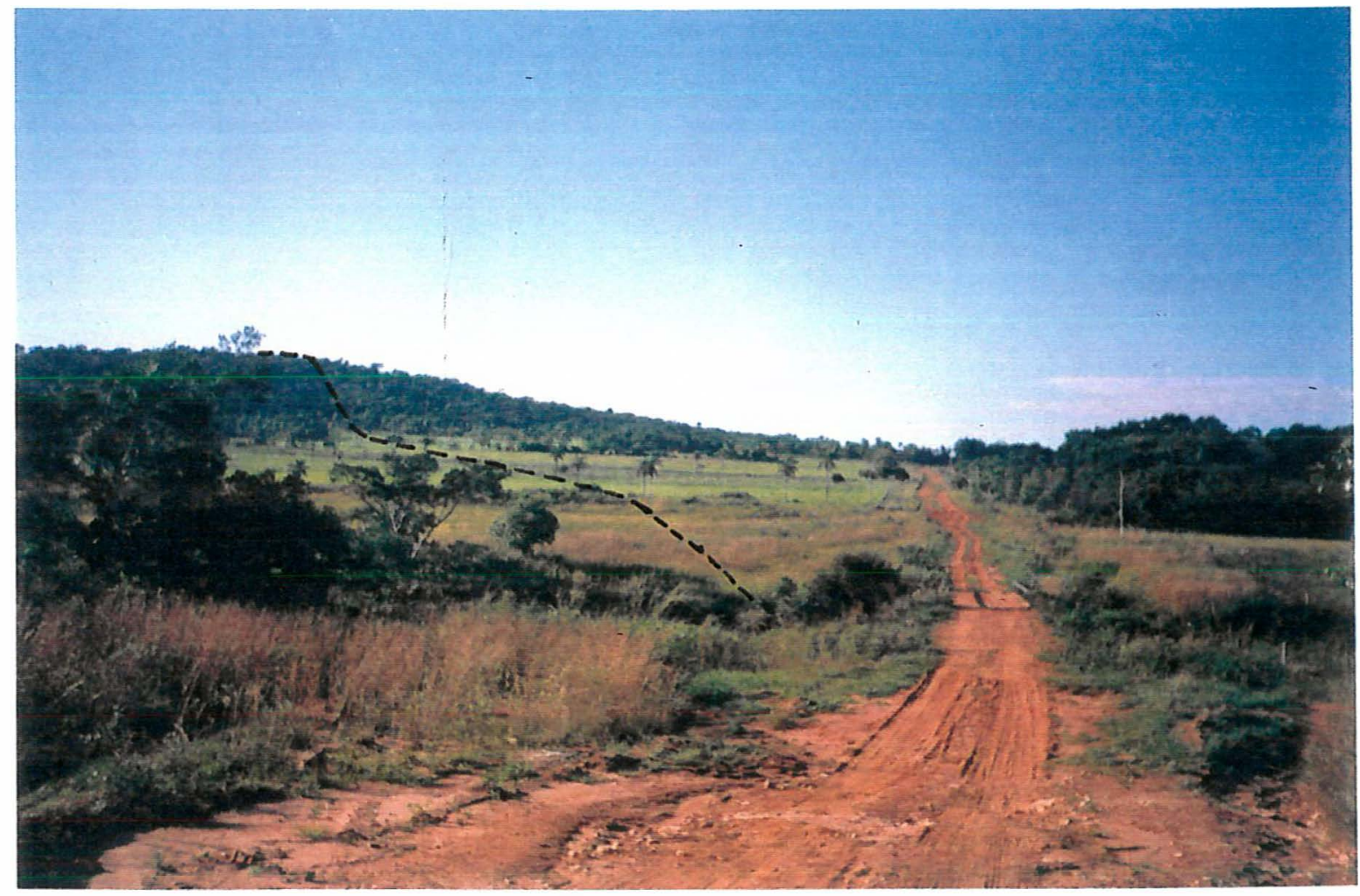

b

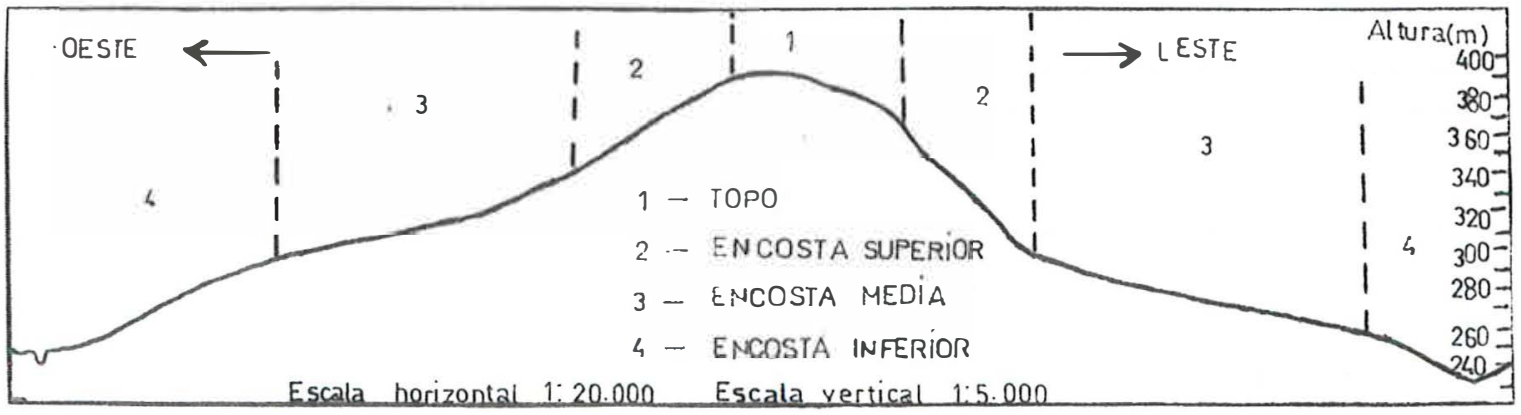

Figura 15 - Paisagem das colinas convexo-côncavo-convexas (a) e perfil representativo das mesmas com relação de escalas $S=4$ (b). 
A vegetação original é também a floresta subtropical subperenifólia em toda a colina, com diferentes alturas segundo a posição topográfica, geralmente de 15$20 \mathrm{~m}$ nos topos e de 25-30 m nas demais posições topográficas. O uso da terra é predominantemente florestal e/ou pastoreio nos topos e nas encostas pedregosas, agrícola e/ou pastoreio nas encostas médias e recreativo nos sopés das encostas e pequenas planícies aluviais.

Os principais processos geomórficos observados são; a erosão e a deposição coluvial; o rastejamento e o fluxo sub-superficial da água que foi observado em toda a encosta média e inferior e a partir da concavidade onde o confinamento temporário da água de infiltração durante vários dias depois das chuvas impediu a escavação das trincheiras para observação e amostragem do solo.

\subsubsection{Colinas escalonadas (c.e.)}

Estas colinas situam-se na parte central da serra, fazendo parte do "horst" principal, com cotas que vão de 200 a 513 m.s.n.m. Esta última altura localizada no topo do Morro Mongelos, caraterizadas por uma alternância de escostas, escarpas e terraços em forma escalonada que descem aos Riachos "Corriente" e "Caraimi" (Figura 11).

A Figura 16 mostra uma vista da paisagem típica desta colina (Figura 16a) e um perfil topográfico da mesma (Figura 16b). Os segmentos topográficos identificáveis nas fotos aéreas são: o topo, a escarpa, a encosta superior, o terraço, a encosta média e a encosta inferior, sendo que as rochas predominantes são constituidas por arenitos arcosianos.

O relevo é fortemente ondulado a montanhoso com declive que varia de 2 a $8 \%$ nos topos e terraços, passando por declives de 7 a $20 \%$ nas encostas e até 45 a $60 \%$ nas escarpas, havendo diferenças significativas nas formas, nos declives, nos comprimentos da rampa e nos solos desta colina, dependendo da direção da vertente e da posição topográfica. 
a
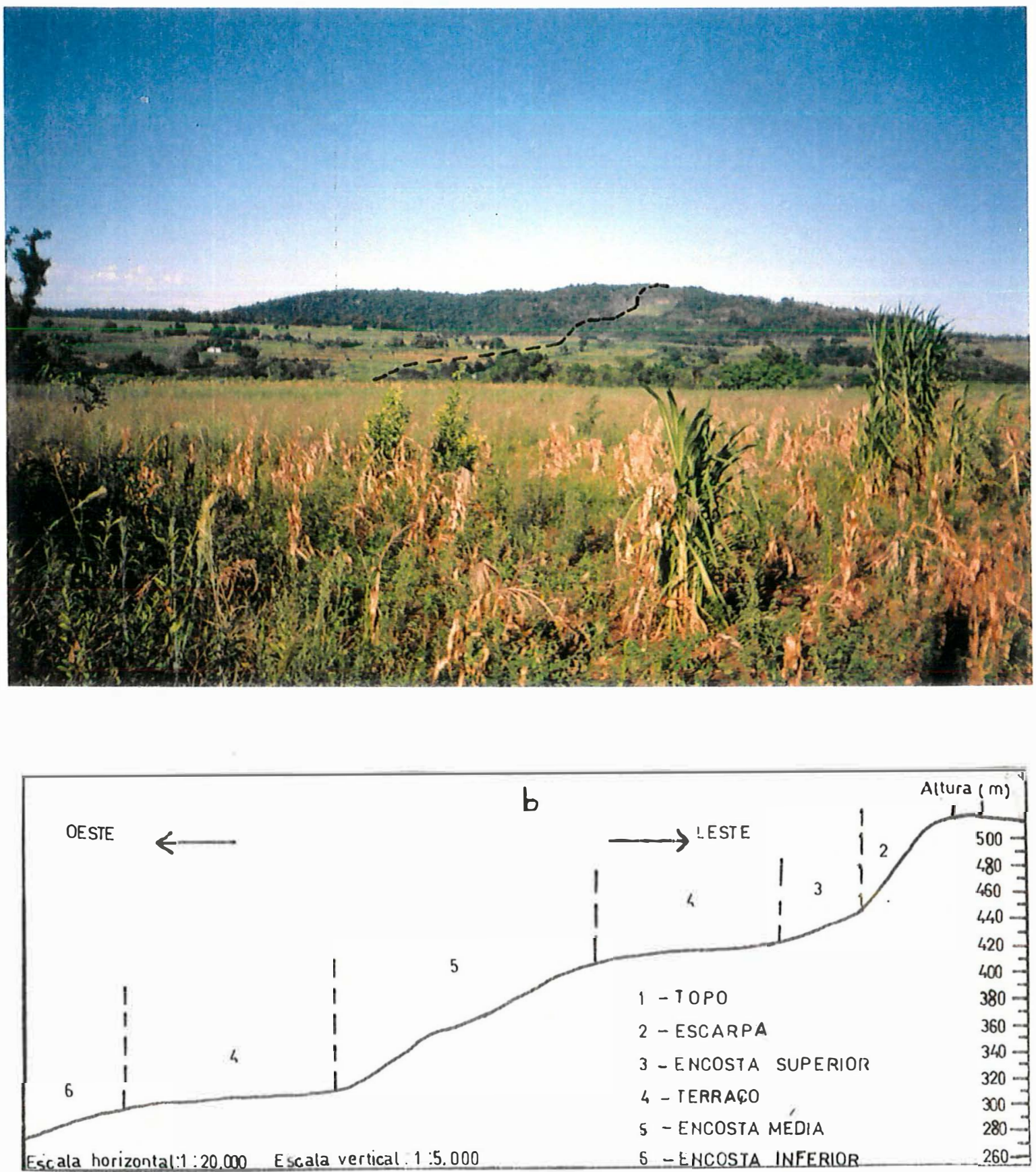

Figura 16 - Paisagem característica clas colinas escalonadas (em $2^{\circ}$ plano) (a) e perfil topográfico com relação cle escalas $S=4(\mathrm{~b})$. 
Os solos dos topos e terraços são rasos à pouco profundos $(0,3-0,6 \mathrm{~m})$, vermelhos-escuros, de textura média e com presença de camada concrecionária laterítica entre o "solum" e a alterita, passando para muito rasos ( $<0,3 \mathrm{~m}$ ), brunos-amarelados, de textura areia franca nas escarpas e encostas médias com rochosidade e pedregosidade em grau forte, enquanto que nas encostas superiores e concavidades ocorrem solos vermelhos-amarelos profundos (1-2 $\mathrm{m}$ ) a brunos-amarelados, de textura franco-arenosa, e ainda, solos muito profundos ( $>2 \mathrm{~m}$ ) vermelhos-amarelos, de textura média com pouco gradiente textural, em alguns terraços e encostas inferiores.

A vegetação original é a floresta subtropical subperenifólia, com diferentes alturas dependendo da posição topográfica e dos solos, geralmente de $10 \mathrm{~m}$ no topo e nos patamares e de 20-30 m nas encostas. O uso é predominantemente florestal de exploração e em menor escala pastoreio extensivo por causa da inacessibilidade da área.

Em alguns setores desta colina foi observado erosão em grau forte, formando sulcos profundos e até voçorocas, assim como alguns sedimentos superficiais arenosos nas cabeceiras das nascentes de água (provavelmente fluxo de terra e lama), e também o confinamento temporário das águas de infiltração das chuvas no topo das camadas $\mathrm{Cr}$ dos solos situados em alguns terraços e concavidades do relevo.

\subsubsection{Morros testemunhos (m.t.)}

Os morros testemunhos situam-se predominantemente no lado Oeste da serra e estão constituídos por rochas intrusivas básicas e alcalinas (gabro, sienito, fonolito) com cotas que vão desde 150 até 559 m.s.n.m., esta última situada no topo do Morro "San José".

Na Figura 17a pode-se observar o Morro "Sao José" e um perfil topográfico do mesmo (Figura 17b). Os segmentos topográficos indentificáveis nas fotos 
a.

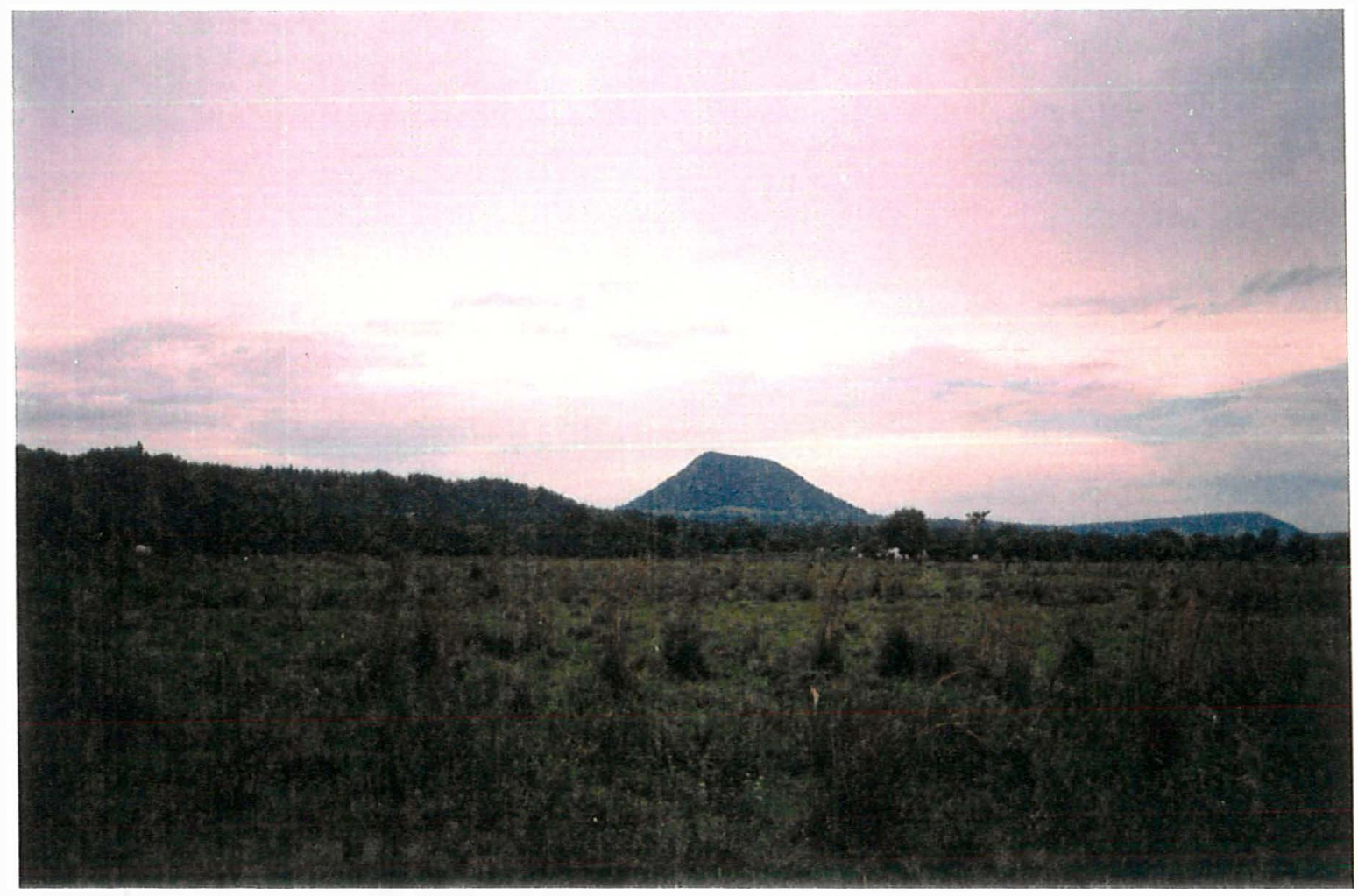

b

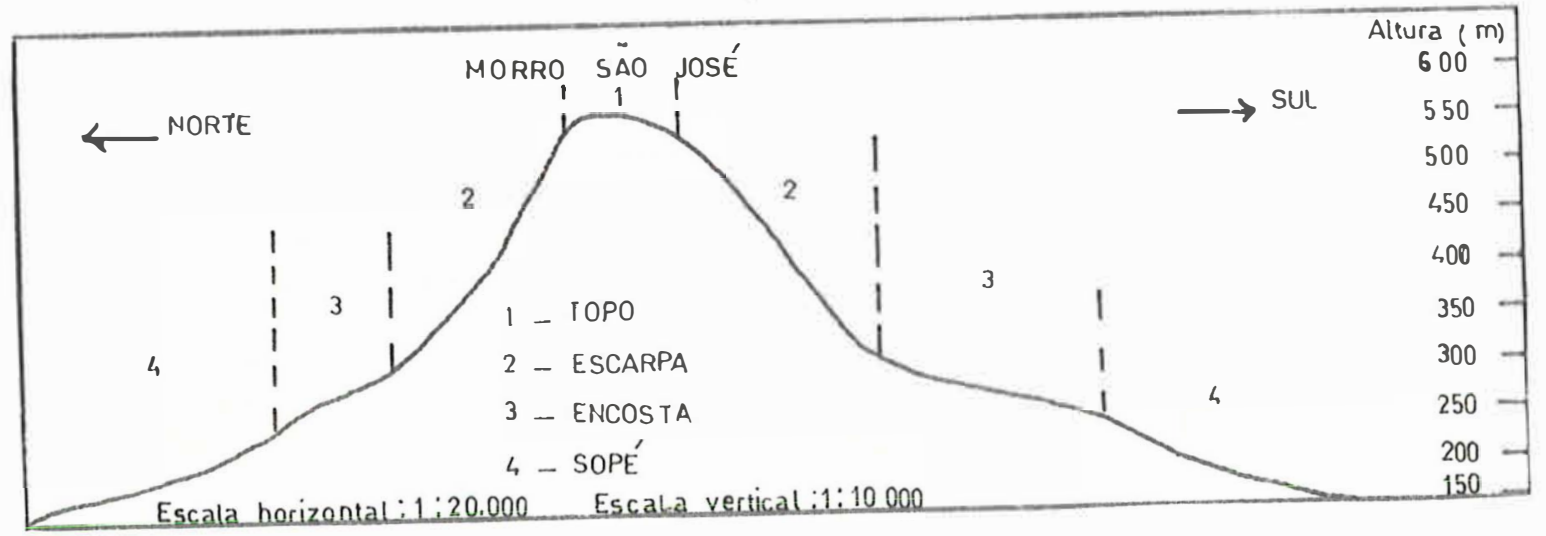

Figura 17 - Paisagem do Morro "Sau José" (a) e perfil topográfico (b), com relação) (le escalas $S=2$. 
aéreas são: o topo, a escarpa, a encosta e o sopé. O relevo é fortemente ondulado a montanhoso com declives que variam de 2-7\% nos topos, 8-100\% nas escarpas, de 6 a $10 \%$ nas encostas e de $6-15 \%$ nos sopés.

Nos topos e escarpas ocorrem solos muito rasos $(<0,3 \mathrm{~m})$; enquanto que nas encostas e sopés ocorrem solos profundos $(1,2-1,8 \mathrm{~m})$ com cores geralmente pretas e textura franco-argilo-siltoso, horizonte superficial A chernozêmico, solos que ocorrem em quase toda a encosta Oeste da serra devido à presença de grande quantidade de rochas intrusivas alcalinas. A vegetação predominante é a floresta subtropical subperenifólia com alturas que variam de 15 até $30 \mathrm{~m}$ de altura, dependendo da profundidade do solo e da posição topográfica. O uso é agrícola nos sopés ou pastoreio extensivo e florestal nas encostas mais declivosas.

Existem também outras colinas testemunhas tanto do lado Norte e do lado Suleste da serra, tendo-se observado principalmente processos erosivos em grau moderado a forte, com formação de sulcos e pequenas voçorocas nas terras dedicadas principalmente à agricultura, sendo portanto, o processo de erosão hídrica e a deposição coluvial, as principais causas do modelado destes morros.

\subsubsection{Encostas convexo-côncavas de frente de falhas (e.c-c-f-f.)}

Estas encostas constituem a borda da serra, com alturas que variam desde 150 até $500 \mathrm{msnm}$ (Figura 11). Os segmentos topográficos identificáveis nas fotos aéreas são: o topo, escarpa, encosta e sopé, podendo ocorrer patamares em alguns setores.

As quebras do relevo são bem nítidas, sendo de fácil separação nas fotos aéreas, tendo os sopés uma declividade de 3-5\%, as encostas de 5-20\%, as escarpas de 20-60\% e as cimeiras e patamares de 1-3\% (Figura 18). 
a.

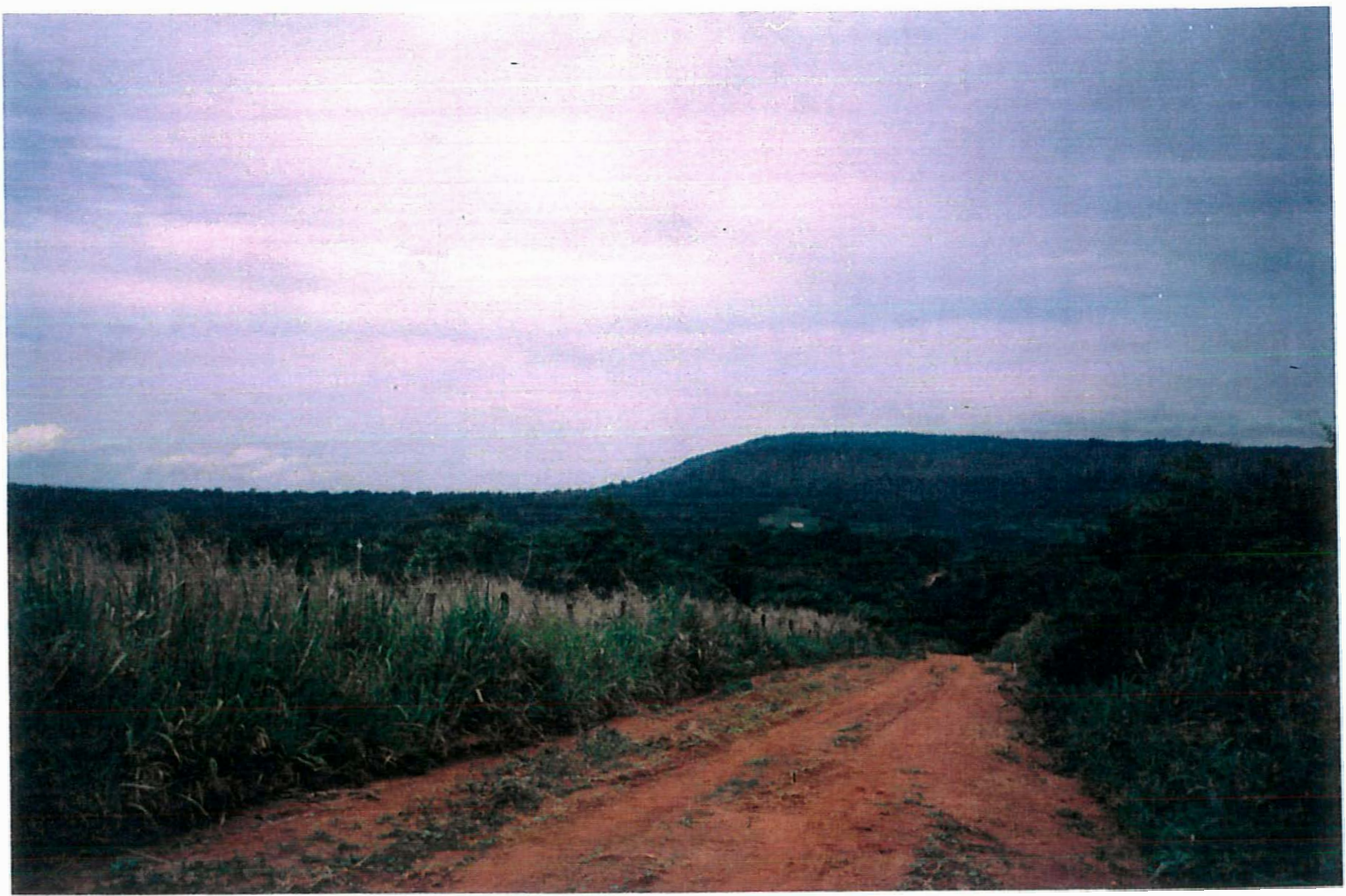

b

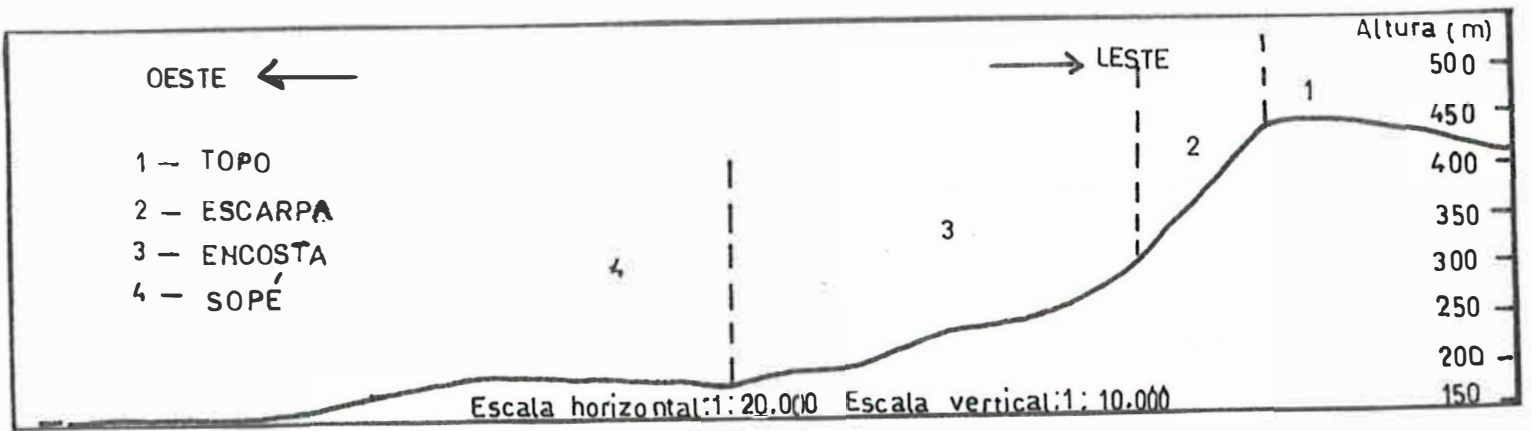

Figura 18 - Paisagem das colinas convexo-côncavas de frente de fallha (a) e perfil topográfico, com relação de escalas $S=2$ (b). 
Nas cimeiras ocorrem solos geralmente moderadamente profundos $(0,5$ $0,7 \mathrm{~m})$, brunos-escuros, de textura areia franca, passando para rasos $(<0,2 \mathrm{~m})$ brunos escuros nas escarpas; solos arenosos muito profundos $(>2 \mathrm{~m}$ ) brunos-amarelados nos sopés, os quais apresentam atributos muitos variáveis, dependendo do material de origem, da posição topográfica e da orientação das linhas de falhamento. No setor Norte, por exemplo, ocorrem solos vermelhos-amarelos derivados de arenitos do Permiano e nas encostas da borda Oeste solos derivados das rochas alcalinas.

A vegetação original é a floresta subtropical subperenifolia com diferentes alturas dependendo da posição topográfica e da profundidade do solo. O uso é principalmente florestal de exploração e pastoreio extensivo nos topos e escarpas, agricultura nas encostas e pastoreio nos sopés.

Em alguns setores desta unidade foram observadas linhas de pedras nos perfís de solos situados nos sopés, assim como erosão forte com formação de voçorocas e grande quantidade de matacões nas encostas e nos sopés das escarpas, os quais evidenciam os processos de esculturação do relevo, sendo principalmente: a erosão hídrica, a deposição coluvial e os movimentos rápidos de massa (desmoronamento, fluxo de terra e lama, etc.).

Em alguns setores desta unidade observou-se a ocorrência de fluxo de terra e lama, formando os leques aluviais que se estendem desde as encostas até as planícies aluviais, formando até vales encaixados em formas de "V" a nível das escarpas. Também foram encontradas evidências do falhamento na base da escarpa de falha como restos do conglomerado mostrando o espelho da falha que corta os seixos de quartzo.

\subsubsection{Leques aluviais (1.a.)}

Os leques aluviais encontram-se predominantemente na encosta do Norte da serra, com cotas que variam desde 130 até 300 m.s.n.m., conformando vales em "V" nas escarpas e encostas mais altas da borda da serra que logo gradacionam para um 
a

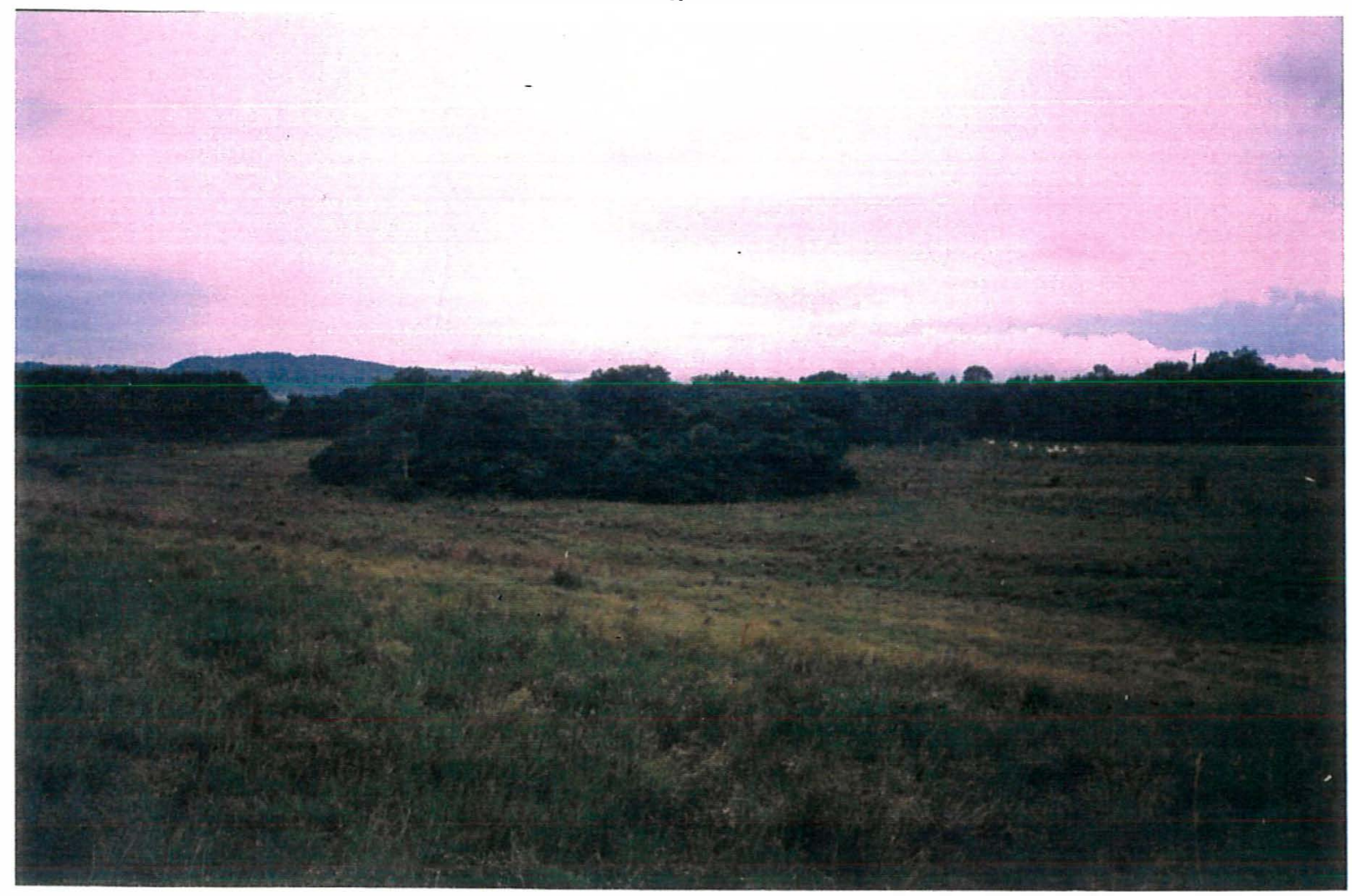

b

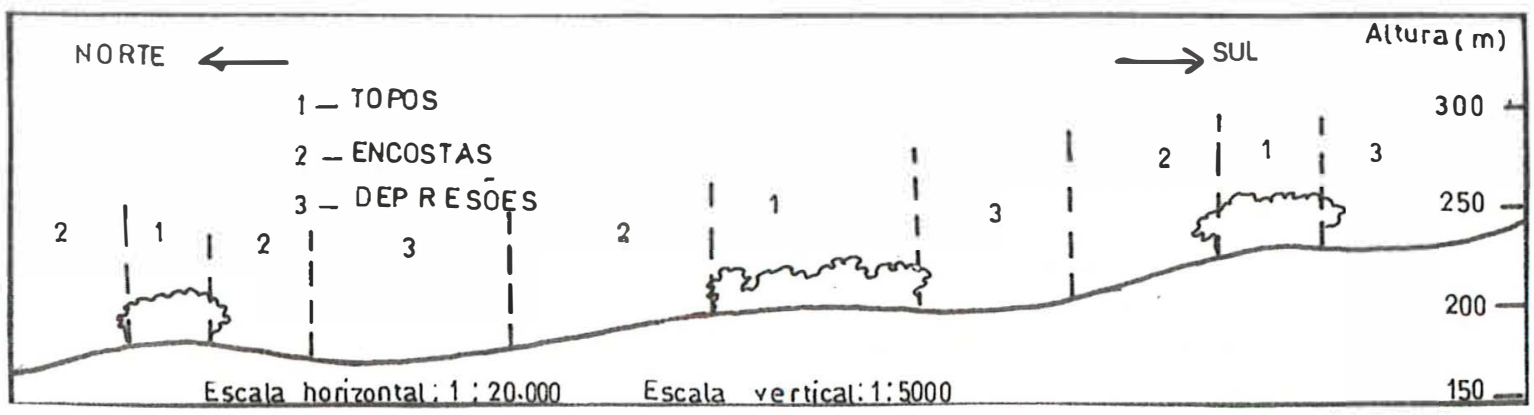

Figura 19 - Paisagem do leque aluvial (a) e perfil topográfico com uma relação de escalas $S=4$ (b) (no primeiro plano). 
curso hídrico sinuoso que desce entre as relíquias de arenito e os depósitos superficiais com diferentes texturas. Também existem leques aluviais nas encostas do lado Oeste da serra, assim como pequenos leques aluviais no curso inferior do Riacho "Corriente" na parte Sul da serra.

Na Figura 20 pode-se observar uma paisagem e o perfil topográfico do leque aluvial do Riacho "Paso Tranquera", identificando-se os seguintes segmentos topográficos: topos, encostas e depressões.

Os solos variam desde arenosos muito profundos $(>2 \mathrm{~m})$ brunosamarelados nas depressões mal drenadas, solos profundos (1-2 m) brunos-escuros, pretos ou acinzentados com texturas muito variáveis nas encostas moderamente drenadas e solos rasos a moderadamente profundos (0,3-0,8 m) nos topos.

A vegetação varia desde floresta subtropical subperenifólia até floresta hidrófila de várzea nos topos e "ilhas" mais elevadas e campo subtropical hidrófilo de várzea nas encostas geralmente curtas e nas depressões onde há acumulação permanente de água. O uso da terra é principalmente pastoreio extensivo nas depressões e florestal nos topos (ilhas).

O relevo dos leques aluviais varia desde moderadamente ondulado até plano, ocorrendo o primeiro nas "ilhas" com afloramentos rochosos e o segundo nas depressões de maior sedimentação, onde a drenagem é geralmente impedida.

Os principais processos de modelagem do relevo são: a erosão fluvial, a deposição diferencial dos materiais de origem (depósitos superficiais recentes), produzidos provavelmente por fluxos de terra e lama e a erosão de materiais provenientes das escarpas e das posições mais elevadas, processos que foram evidenciados pela presença de linhas de pedras encontradas entre o solum e a regolita de rochas muito diferentes, provavelmente arenitos da Formação Misiones e/ou do período permiano. 


\subsubsection{Planícies aluviais (p.a.)}

Na parte interior da serra ocorrem pequenas planícies aluviais de pouca largura, as quais sāo interrompidas ao longo dos cursos hídricos, porém, fora da serra existem amplas e importantes planícies aluviais como as dos Riachos "Tevicuary", "Cristal", "Ybycu'i" e "Sanja hû".

Na Figura 20 pode-se observar a paisagem e um perfil topográfico com direção Leste-Oeste da planície aluvial do Riacho "Ybycu'i" perto de "La Rosada" já saindo da serra, onde os sedimentos aluviais transportados misturam-se com os sedimentos de origens fluviais, onde ocorrem geralmente algumas lagunas e depressões mal drenadas.

O relevo é plano com declives que variam de 0 até $2 \%$, com diferentes comprimentos e direções e os principais processos geomórficos que modelaram estas planícies são: a erosāo fluvial, a deposição de sedimentos arenosos no leito (areias grossas) e nas margens (siltes e areias) dos riachos, assim como o desmoronamento das paredes dos canais hídricos.

Os solos das planícies sāo muito variáveis e para caracterizá-los é necessário realizar estudos e levantamentos detalhados específicos para cada planície, tendo-se verificado a ocorrência de Solos Aluviais típicos em algumas várzeas das planícies aluviais do lado Norte da serra perto do povoado de "Tevicuarymi". A vegetaçāo é predominantemente campo subtropical hidrófilo de várzea e floresta subtropical higrófila de várzea, sendo os usos principais o pastoreio extensivo e/ou o florestal de preservação. Em todas as planícies aluviais do interior da serra observou-se que os leitos arenosos alternam-se com pequenas quedas e cachoeiras de água, sendo o leito rochoso constituido principalmente de arenito, assim como sedimentos arenosos em forma de dunas paralelas ao curso hídrico, as quais se interdigitam com os sopés das colinas e também com leques aluviais em alguns setores. 
2

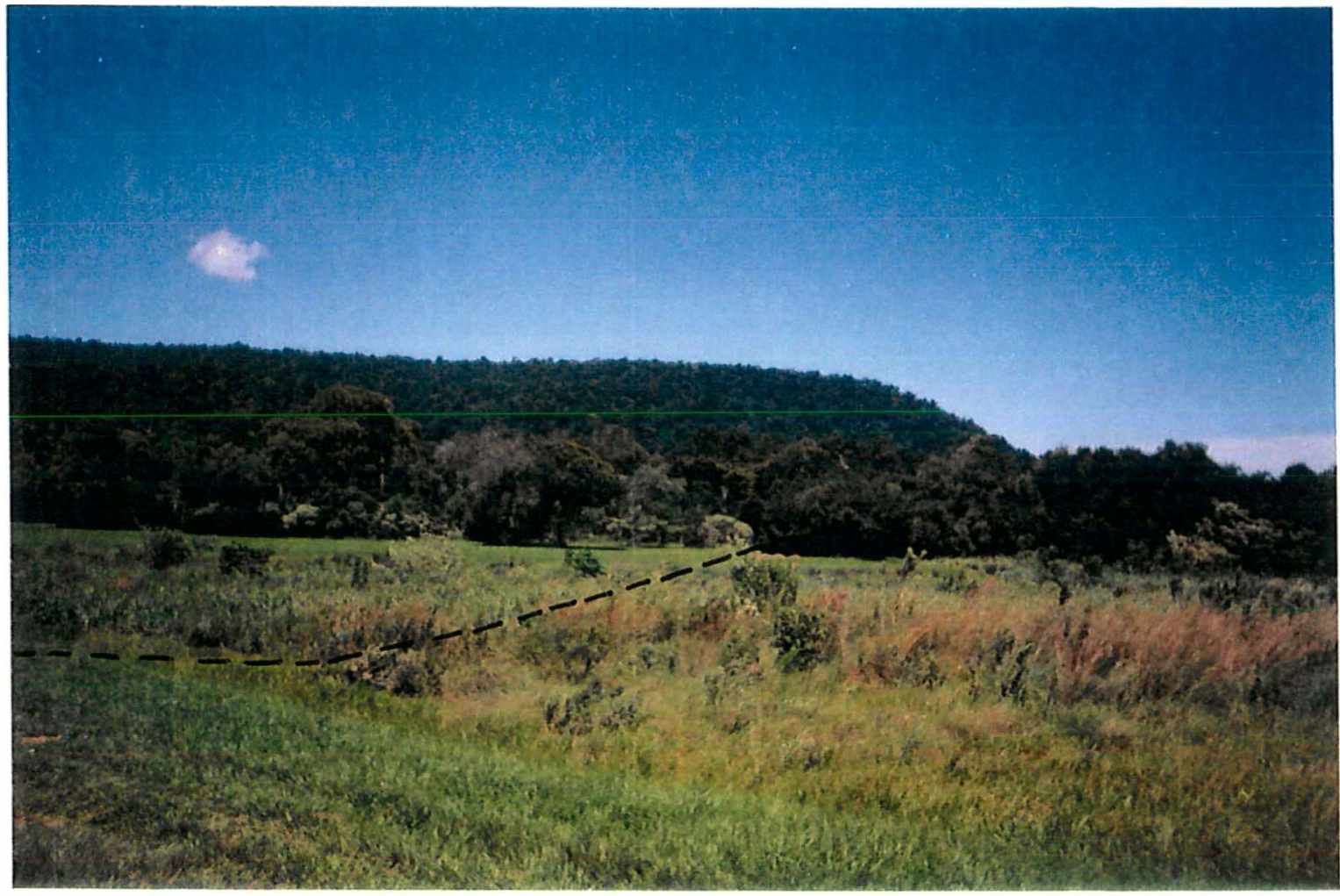

b

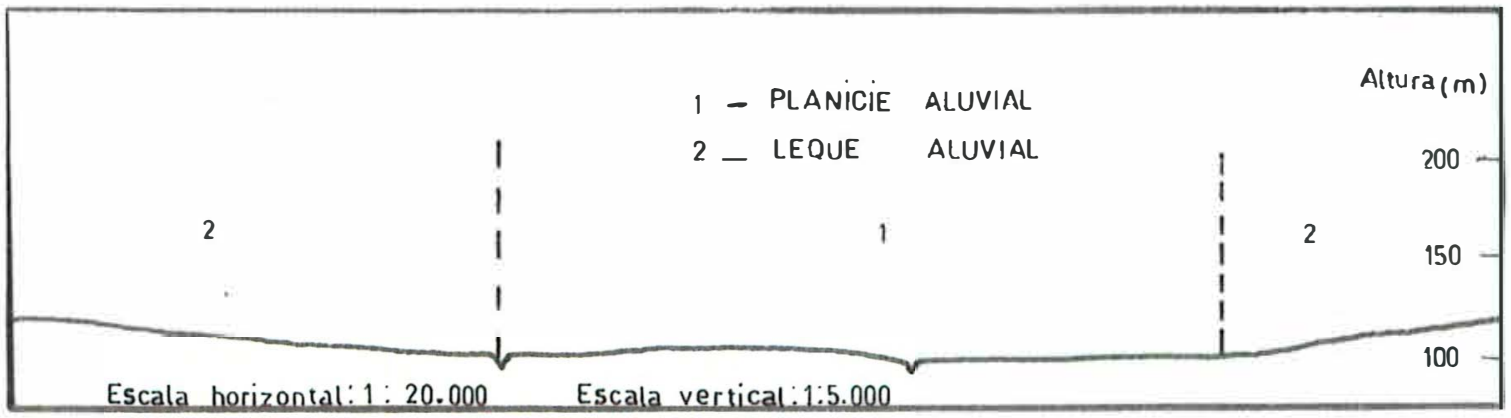

Figura 20 - Paisagem da planície aluvial clo Riacho "Ybycu'i" no extremo sul cla serra, em "La Rosada" (em primeiro plano) (a) e perfil topográfico com direção Oeste-Leste e relação de escalas $S=4$ (b). 


\subsection{Solos}

Em seqüência, são apresentadas as principais caraterísticas e propriedades

dos 15 solos agrupados segundo o grau de desenvolvimento do perfil, para o qual considerou-se o valor do IDP e a seqüência dos horizontes que o solo apresenta, sendo que os dados morfológicos dos perfís e os resultados das análises de laboratório constam no anexo.

\subsubsection{Solos fracamente desenvolvidos}

Os solos fracamente desenvolvidos estão constituídos pelos perfís 11 e 40 . O perfil 11 tem uma seqüência de horizontes $\mathrm{ACCr}$ e um IDP $=18,0$, enquanto que o perfil 40 tem uma seqüência OACCr e um IDP $=7,8$, ocupando ambos os topos das colinas convexas e das convexo-côncavo-convexas (cristas), tendo o primeiro uma vegetação de gramíneas e o segundo vegetação de mata nativa.

A espessura do horizonte A varia muito pouco, de $14-15 \mathrm{~cm}$, sendo que a espessura do horizonte $C$ varia de $24-36 \mathrm{~cm}$ no perfil 40 a $35-55 \mathrm{~cm}$ no perfil 11 , com transição gradual e ondulada entre o horizonte A e a camada $C$ no perfil 11 e gradual e plana entre o horizonte A e a camada C no perfil 40 , enquanto que a transição entre as camadas $\mathrm{C}$ e $\mathrm{Cr}$ de ambos os solos é abrupta e quebrada com línguas do $\mathrm{C}$ penetrando no $\mathrm{Cr}$. A determinação da profundidade da transição entre o $\mathrm{Cr}$ e o $\mathrm{R}$ foi difícil, por ter o $\mathrm{Cr}$ consistência em úmido dura, que não se deixa cortar por uma pá reta, não obstante possa ser escarificada.

A cor (úmida) destes solos é geralmente bruno escuro (7.5 YR 3/2 a 7.5 YR 3/5), contrastando nitidamente com a cor mais clara da camada $\mathrm{Cr}$, que é geralmente bruno-clara-acinzentada (10 YR 6/3) ou rosada (7.5 YR 7/4). A capacidade de agregação do horizonte $A$ é fraca, sendo os agregados de tamanhos muito pequenos a grandes, de formas granulares e blocos subangulares, passando para blocos 
subangulares pequenos e grandes, de grau também fraco na camada C. A consistência em seco do horizonte A é geralmente macio, solto em úmido e não plástico nem pegajoso quando molhado, enquanto que na camada $C$ é geralmente macio, friável, não plástico e nem pegajoso.

Na Figura 21 pode-se observar algumas fotomicrografias representativas destes solos e na Tabela 2 são apresentadas as suas principais características micromórficas. O solo sob a mata nativa (perfil 40) por exemplo, apresenta desenvolvimento de microagregados, assim como maior quantidade de plasma e de vazios que o solo sob gramíneas (perfil 11), provavelmente devido à contribuição da matéria orgânica.

$O$ perfil 40 tem esqueleto moderamente selecionado com os grãos maiores esféricos e arredondados e os menores tabulares e subarredondados (ea/tsa), enquanto que o esqueleto do perfil 11 é mal selecionado com os grãos maiores esféricos e bem arredondados e os menores subesféricos e subarredondados (eba/sesa). A estrutura plásmica no perfil 11 é predominantemente guefúrica (Figura $21 \mathrm{e}$ ), enquanto que no perfil 40 é enáulica. Os vazios são mormente mesoporos intergranulares simples nas camadas $\mathrm{C}$ de ambos solos e no horizonte $11 \mathrm{~A}^{3}$, enquanto que o horizonte $40 \mathrm{~A}$ tem mesoporos ortocavitários.

Ambos os solos apresentam poucos nódulos ferruginosos, pequenos e irregulares em todo o perfil, inclusive nas camadas $\mathrm{Cr}$ (ver anexo), os quais também foram observados nas lâminas delgadas (Figura 21a,b), verificando-se que os mesmos originaram-se por preenchimento de plasma isótico nas fendas de fraturamento (Figura 21c). Por outro lado, existem forte indícios de que tais nódulos estejam sofrendo degradação, podendo-se observar na Figura 21d um poro metacavitário dentro de um nódulo ferruginoso do horizonte 11 A preenchido com siltans, sílica secundária e cutãns de difusão na parede.

\footnotetext{
${ }^{3}$ Afim de facilitar a identificação do perfil do solo, optou-se pela denominação do número do perfil seguido pelo tipo de horizonte: $11 \mathrm{~A}, 40 \mathrm{C}, 30 \mathrm{Bt}$, etc.
} 
Observou-se também que os grãos de areia destas camadas $\mathrm{Cr}$ tem uma estrutura compacta, causada provavelmente por efeito do metamorfismo, que é característico de rochas quartzíticas (Figura $21 \mathrm{f}$ ).

A variação da textura com a profundidade destes solos é mínima, sendo por exemplo no perfil 11 areia franca em todo o perfil, com 80-100 g/kg de argila, 20$60 \mathrm{~g} / \mathrm{kg}$ de silte e 840-900 g/kg de areia, enquanto que no perfil 40 a textura varia de franco-arenosa com 120-140 g/kg de argila, 40-60 g/kg de silte e $820 \mathrm{~g} / \mathrm{kg}$ de areia no horizonte A para areia franca com $100 \mathrm{~g} / \mathrm{kg}$ de argila, $60 \mathrm{~g} / \mathrm{kg}$ de silte e $840 \mathrm{~g} / \mathrm{kg}$ de areia na camada C. O grau de floculação das argilas dos dois solos tendem a diminuir com a profundidade, sendo de $57-68 \%$ na superfície e de $40 \%$ na camada $C$, não havendo sido observado nenhum tipo de cerosidade no campo, porém, nas lâminas delgadas do perfil 11 (horizontes A e C) observaram-se cutãns de contração.

O teor de carbono orgânico no horizonte $11 \mathrm{~A}$ é de $5,8 \mathrm{~g} / \mathrm{kg}$, enquanto que no horizonte $40 \mathrm{~A}$ chega a $23,7 \mathrm{~g} / \mathrm{kg}$, sendo que na camada $\mathrm{C}$ varia de 2,8 a $15,6 \mathrm{~g} / \mathrm{kg}$ nos perfís 11 e 40, respectivamente; enquanto que na camada Cr há uma tendência do C orgânico de aumentar novamente para teores de 4,6-5,8 g/ $\mathrm{kg}$, nos perfís 11 e 40, respectivamente.

$\mathrm{O}$ pH também tem um comportamento similar: diminui em profundidade e logo aumenta na camada $\mathrm{Cr}$, observando-se uma relação dos valores de $\mathrm{pH}$ com os valores de saturação por bases, de alumínio trocável, de fósforo assimilável e de teor de $\mathrm{C}$ orgânico, assim à uma diminuição do $\mathrm{pH}$ com a profundidade, acompanha uma diminuição do $\mathrm{C}$ orgânico, do $\mathrm{V} \%$ e do $\mathrm{P}$ assimilável, com aumento importante de $\mathrm{Al}^{3+}$.

Os difratogramas do raio-X da fração silte destes solos (dados não apresentados) mostraram picos correspondentes à espaçamento de quartzo e de pirofilita, este último relacionado freqüentemente com processos metamórficos, enquanto que nas lláminas delgadas observou-se a presença de micas do tamanho do silte (Figura 2 la,f). Na Figura 21 são apresentados os difratogramas do raio- $X$ mais representativos da fração argila do perfil 11 (horizonte C e camada $\mathrm{Cr}$ ). 


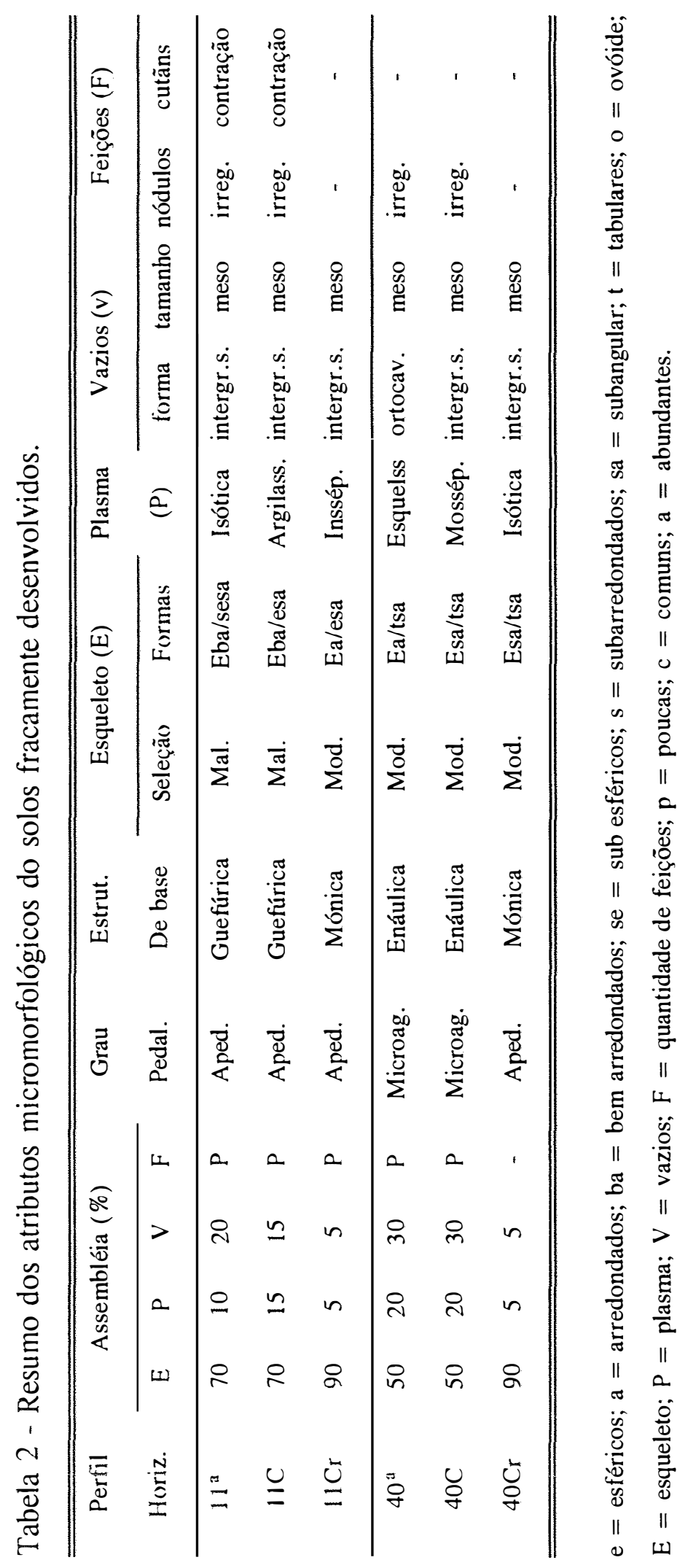


a

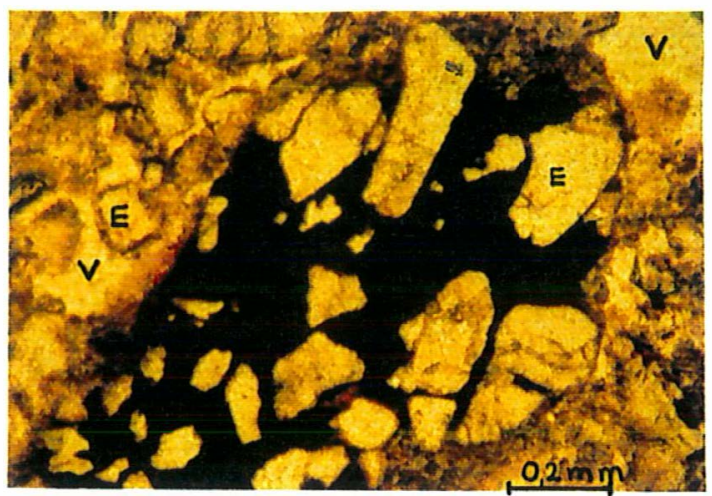

c

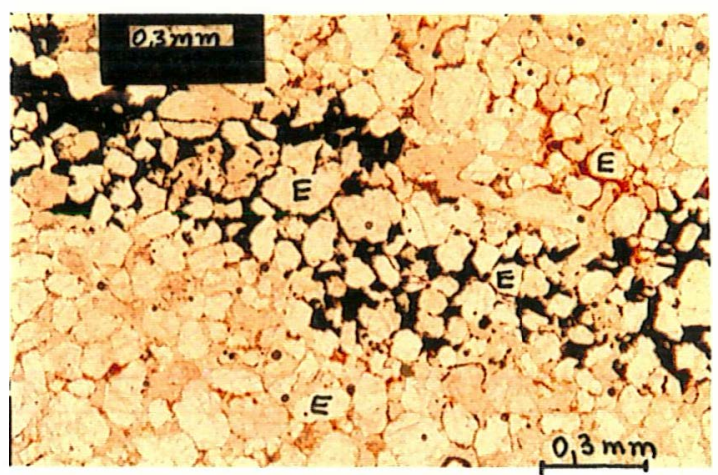

e

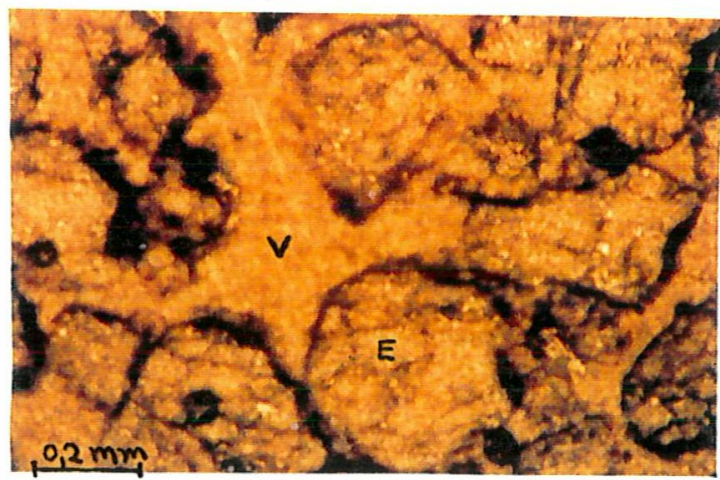

b

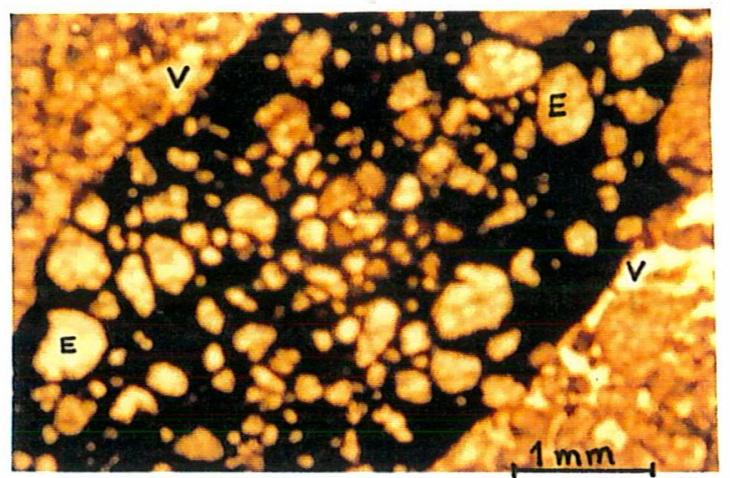

d

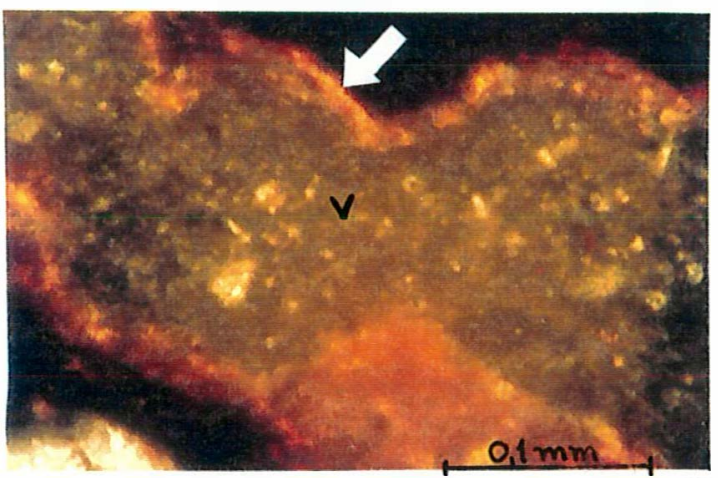

f

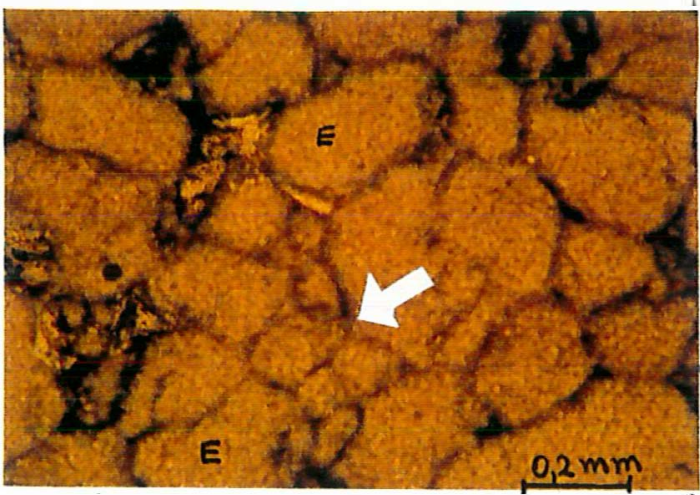

Figura 21 - Fotomicrografias dos solos fracamente desenvolvidos: a) nódulo ferruginoso do horizonte $11 \mathrm{~A}(\ln ) ; \mathrm{b})$ nódulo ferruginoso na camada 1 IC (ln); c) microfratura preenchida com ferro na camada $11 \mathrm{Cr}(\ln )$; d) poro ortocavitário de um nódulo do horizonte llA (nc); e) estrutura de base guefúrica na camada I1C (ln); f) estrutura do arenito adensado na camada 40Cr $(\ln )$. 
Na Figura 22 são apresentados os difratogramas dos raios $X$ mais representativos da fração argila do perfil 11 (horizonte $\mathrm{C}$ e camada $\mathrm{Cr}$ ). A presença de Caulinita (picos correspondentes a espaçamentos de 3,5 e 7 angstrons nas argilas tratadas com $\mathrm{K} 25^{\circ} \mathrm{C}$ e com $\mathrm{Mg} 25^{\circ} \mathrm{C}$ ) e de mica (picos correspondentes a espaçamentos de 3,3 e 5,0 e 10 angstrons dos mesmos tratamentos) nas camadas $\mathrm{C}$ e $\mathrm{Cr}$ destes solos, confirmam por um lado a hipótese de campo pela qual definiu-se a camada $\mathrm{Cr}$, ou seja que o material subjacente e com características muito diferentes às do solo nao é mais uma camada $\mathrm{R}$ por ter sofrido intemperismo e formação de caulinita e, por outro, reforça a hipótese de que estes solos derivam do material subjacente, por ter os mesmos minerais e porque tais picos mostram-se mais desenvolvidos na camada $\mathrm{Cr}$, sugerindo que tem maior quantidade desses minerais e de melhor cristalinidade.

A atividade da argila (após desconto da contribuição da matéria orgânica) destes solos é geralmente alta, sendo de $793 \mathrm{mmol} / \mathrm{kg}$ de solo na camada $40 \mathrm{C}$ e de 315 $\mathrm{mmol} / \mathrm{kg}$ na camada $1 \mathrm{lC}$, diferença que poderia ser atribuida à presença de vermiculita (a mais de ter também caulinita e mica) na camada 40C (dados não apresentados).

Os valores de $\mathrm{Ki}$ (relação sílica/alumínio) destes solos (ver anexo) sugerem que entre ambos, o mais intemperizado é o perfil 11 , cuja camada $C$ tem um índice $\mathrm{Ki}=1,73$, enquanto que a camada $40 \mathrm{C}$ tem um índice $\mathrm{Ki}=2,48$.

Estes solos foram classificados como Regossolos segundo Camargo et al. (1987), principalmente devido à ausência de horizonte diagnóstico sub-superficial, tendo ambos uma seqüência de horizontes e camadas $\mathrm{ACCr}$, formados em saprólito e contendo minerais intemperizáveis na fração areia fina $(0,05-0,2 \mathrm{~mm})$, enquanto que segundo o "Soil Taxonomy" (Soil Survey Staff, 1994), estes solos entram na classe "Entisols" por nao reunirem os requisitos das outras 10 ordens.

O perfil 11 foi classificado como Regossolo álico Ta A moderado, textura arenosa, fase floresta subtropical subperenifolia, substrato quartzito, relevo ondulado, o qual não apresenta rochosidade, nem pedregosidade, tendo uma drenagem acentuada, relevo plano com declive de $1-2 \%$, sob uso pastoril e/ou florestal e com grau de erosão moderado do tipo laminar. 

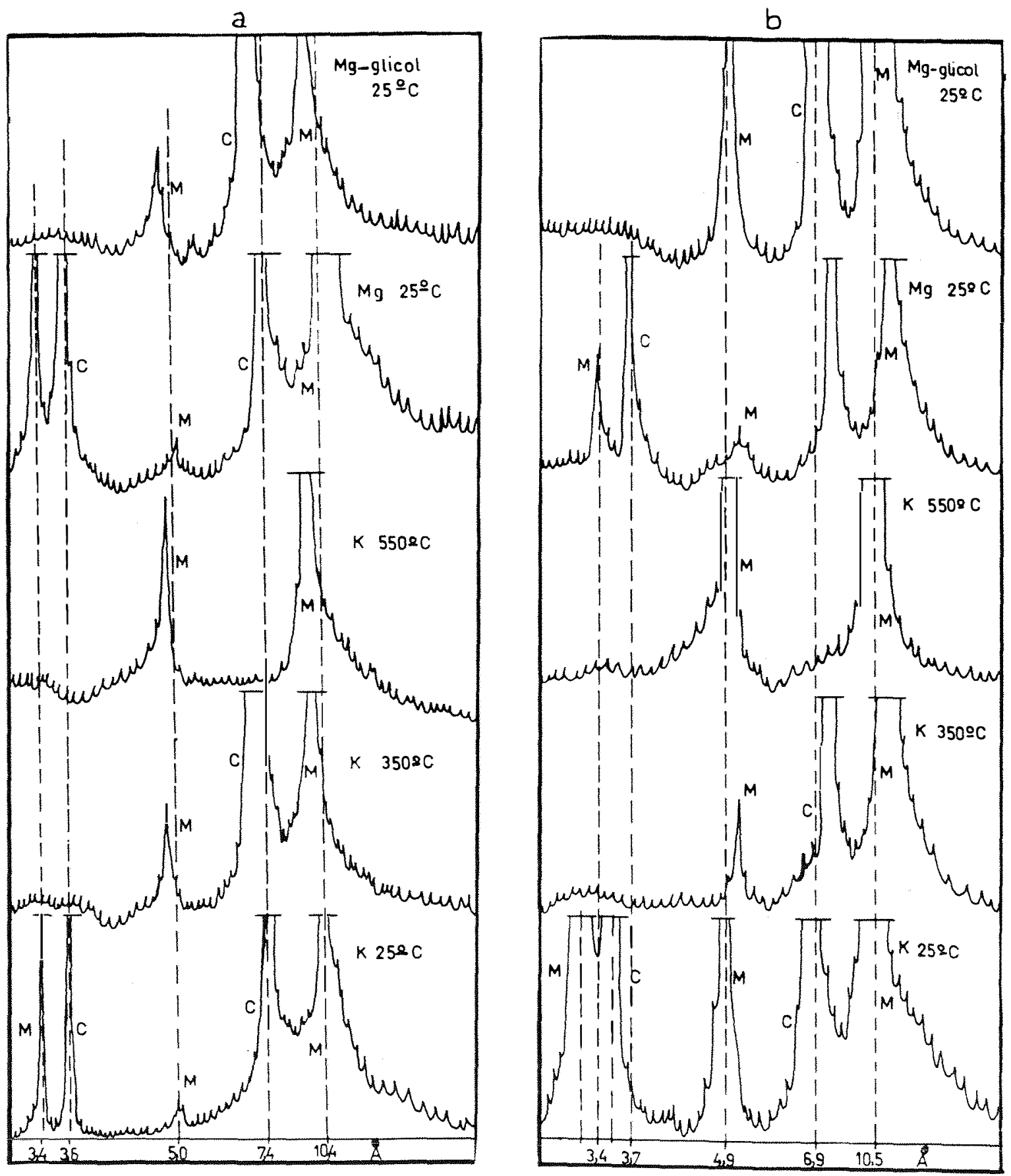

Figura 22 - Difratogramas dos raios- $X$ da fração argila dos solos fracamente desenvolvidos: a) Horizonte $11 \mathrm{C}$; b) Camada $11 \mathrm{Cr}$. $\mathrm{C}=$ caulinita; $\mathrm{M}=$ mica. 
O perfil 40 foi classificado como Regossolo distrófico Ta A moderado, textura arenosa, fase floresta subtropical subperenifolia, substrato quartzito, relevo fortemente ondulado, o qual apresenta rochosidade e pedregosidade em grau ligeiro a moderado, tendo uma drenagem acentuada, relevo plano a fortemente ondulado, com declives que variam de 1 a $30 \%$, sob uso florestal e com grau de erosāo moderado a forte do tipo laminar.

\subsubsection{Solos moderadamente desenvolvidos}

Os solos moderadamente desenvolvidos (perfís 12, 31, 32, 34, 35 e 43), tem uma seqüência de horizontes e camadas $\mathrm{ABiCr}, \mathrm{ABiFCr}$ e $\mathrm{ABiCcCr}$, sendo o perfil 34 o de menor profundidade efetiva $(50 \mathrm{~cm})$, enquanto que os demais são moderadamente profundos $(52-105 \mathrm{~cm})$, com IDP que varia de 14,8 no perfil 34 até 42,3 no perfil 31 .

A espessura do horizonte A varia de $10 / 12 \mathrm{~cm}$ no perfil 34 até $60 \mathrm{~cm}$ no perfil 12 , sendo a espessura do horizonte $B i$ de 25 a $38 \mathrm{~cm}$, enquanto que a camada concressionária e/ou laterítica $F$ varia desde $2 \mathrm{~cm}$ (perfil 12) até $80 \mathrm{~cm}$ (perfil 43). A transição entre os horizontes A e Bi varia de clara e ondulada no perfil 12 a difusa e plana no perfil 35 , sendo que a transição entre o horizonte Bi e F, e entre o $\mathrm{F}$ e o $\mathrm{Cr}$ é sempre abrupta ou clara, ondulada ou descontínua, o que sugere uma limitação para o desenvolvimento de raízes.

A cor (úmida) dos horizontes superficiais varia desde bruno escuro $(7,5$ YR 3/2 - 7,5 YR 3/3) nos horizontes 12Al, 35A e 43Ap a bruno avermelhado escuro (5 YR 3/4) no perfil $32 \mathrm{Ap}$, que sao semelhantes à cor (úmida) dos horizontes subsuperficiais que varia desde bruno escuro (7,5 YR 3/3, 7,5 YR 3/4 e 7,5 YR 4/4) nos horizontes 12Bi, 35Bi e 43Bi, a bruno avermelhado escuro (25 YR 2.5/4) no perfil 32Bi. Porém, a cor (úmida) das camadas F varia de vermelho-escuro acizentado (10 R $3 / 3$ ) na camada $12 \mathrm{~F}$ a vermelho escuro ( $10 \mathrm{R} 3 / 6)$ na camada $32 \mathrm{~F}$, e a cor (úmida) das 
camadas Cc varia de bruno escuro (7,5 YR 3/4) na camada 35Cc a vermelho escuro (2,5 YR 3/6) na camada $43 \mathrm{Cc}$, enquanto que a cor das camadas $\mathrm{Cr}$ é muito mais variável, variando desde cinzento claro (10 YR 7/2) para amarelo (10 YR 7/6) e vermelho amarelado (5 YR 5/8).

A capacidade de agregação destes solos é de grau fraco a moderado, pequeno a médio granular e blocos subangulares nos horizontes $\mathrm{A}$ e médio a grande de blocos subangulares nos horizontes câmbicos, não obstante a micromorfologia revelou que os blocos subangulares compõem-se na maior parte de microagregados (Figura 23a, b). A consistência varia de macio a ligeiramente duro quando seco, comumente friável em úmido e de não plástico nem pegajoso nos horizontes $\mathrm{A}$, sendo ligeiramente plástico e ligeiramente pegajoso nos horizontes $\mathrm{Bi}$, chegando ser até pegajoso no horizonte $31 \mathrm{Bi}$.

Na Tabela 3 é apresentado um resumo dos atributos micromórficos destes solos e na Figura 23, algumas fotomicrografias das láminas delgadas mais representativas. A Figura $23 \mathrm{c}$ mostra que o desenvolvimento de superfícies brilhantes no horizonte $12 \mathrm{Bi}$ é devido às separações plásmicas (cutãns de "stress") e não à translocamentos de argila, não tendo sido observado argila iluvial em nenhum dos horizontes destes solos. A Figura $23 \mathrm{~d}$ mostra a grande concentração de ferro na camada petroplíntica $12 \mathrm{~F}$ de $2 \mathrm{~cm}$ de espessura, observando-se na Figura $24 \mathrm{e}$ que a camada $32 \mathrm{~F}$ apresenta sintomas de desagregação e transformação de ferro pela água e formação de goetita perto dos poros e na Figura $23 \mathrm{f}$ observa-se um poro de origem biológico com goetita formada na parede.

O perfil 35 tem poucos nódulos ferruginosos pequenos, duros e irregulares em todos os horizontes, passando para dominantes na camada Cc e, na Figura 23a, observa-se um nódulo ferruginoso irregular e parte da matriz petroplíntica em processo de desagregação com microagregados coalescentes, sendo que na Figura 23b, observa-se uma zona de contato entre as camadas $\mathrm{Cc}$ e $\mathrm{Cr}$ deste solo que mostra diferenças estruturais importantes entre ambas, como por exemplo, o processo de desagregação na 
camada Cc e a conformação típica dos grãos de areia adensados (provavelmente tamorfizados) na camada $\mathrm{Cr}$, com minerais primários já intemperizados (mica e feldspatos).

As diferenças estruturais entre as diversas camadas $\mathrm{Cc}$ e $\mathrm{F}$ destes solos sugerem que há uma seqüência de transformação petroplíntica causada pela água do solo que se acumula temporariamente no contato entre as camadas $\mathrm{F}$ e $\mathrm{Cr}$ e/ou entre as camadas $\mathrm{Cc}$ e $\mathrm{Cr}$, observando-se assim, camadas totalmente endurecidas e contínuas como, por exemplo, a camada 12F (Figura 23d), camadas petroplínticas descontínuas em processo de redução/oxidação e já com porosidade que permite a retransformação do ferro e reorganização do plasma (camada 32Cc da Figura 23e) e camadas mais desagregadas como a do 35Cc (Figura 23a,b).

Os seis perfís não reunem o requisito de relação textural necessários para identificar un $\mathrm{Bt}$ (B textural), apesar de que há aumento de argila com a profundidade, variando a textura do franco arenoso nos horizontes $12 \mathrm{Al}$, 32Ap, 43Ap e $31 \mathrm{Ap}$ para franco argilo-arenoso nos horizontes $12 \mathrm{Bi}$ e $32 \mathrm{Bi}$ e para argila arenosa nos horizontes $43 \mathrm{Bi}$ e $31 \mathrm{Bi}$, sendo que nos perfís 32 e 35 o aumento de argila em profundidade é menor, sendo a textura franco-arenosa em todo o perfil.

O perfil 32 apresenta um comportamento em profundidade atípico do teor de $\mathrm{C}$ orgânico, pois diminui até certa profundidade e aumenta a maior profundidade. Assim o seu teor diminui desde $12,7 \mathrm{~g} / \mathrm{kg}$ no horizonte Ap para para 8,7 $\mathrm{g} / \mathrm{kg}$ na camada $\mathrm{F}$ e aumentando para 13,8 na camada $\mathrm{Cr}$, tendo-se encontrado matéria orgânica em todas as camadas $\mathrm{F}, \mathrm{Cc}$ e $\mathrm{Cr}$ de todos estes solos, ainda que em pouca quantidade. Os horizontes $12 \mathrm{~A} 1$ e $35 \mathrm{~A}$ são considerados proeminentes por ter todos os requisitos para o mesmo, como valor e chroma em úmido menor que 3,5 e valor em seco menor que 5,5 (Embrapa, 1988), teor de carbono orgânico maior ou igual a $0,6 \%$ nos $18 \mathrm{~cm}$ superficiais e saturação por bases $<50 \%$, enquanto que os horizontes $31 \mathrm{~A}, 32 \mathrm{Ap}, 34$ A e $43 \mathrm{Ap}$ são moderados por ter cores mais claras e/ou pouca espessura. 


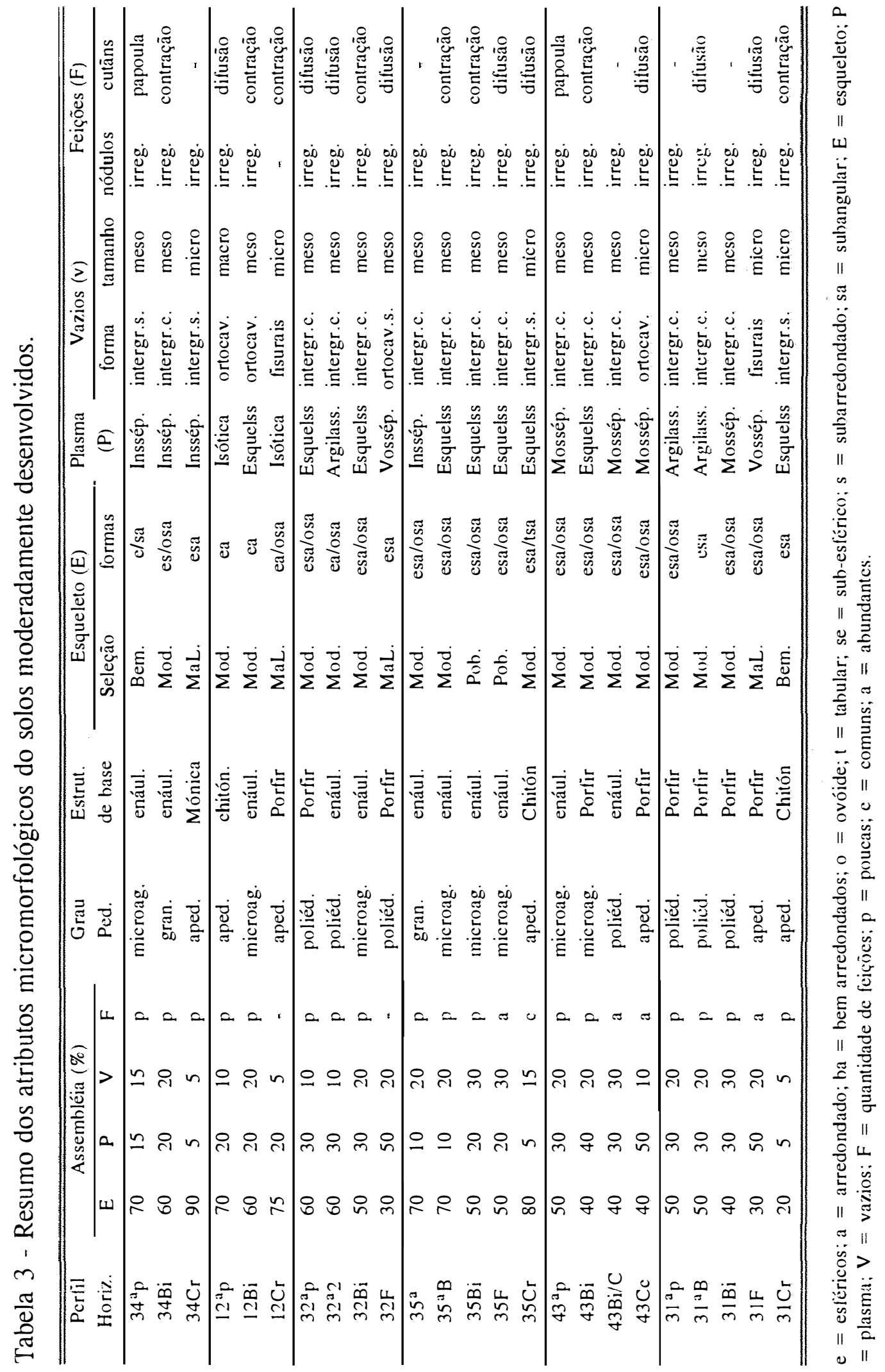


a

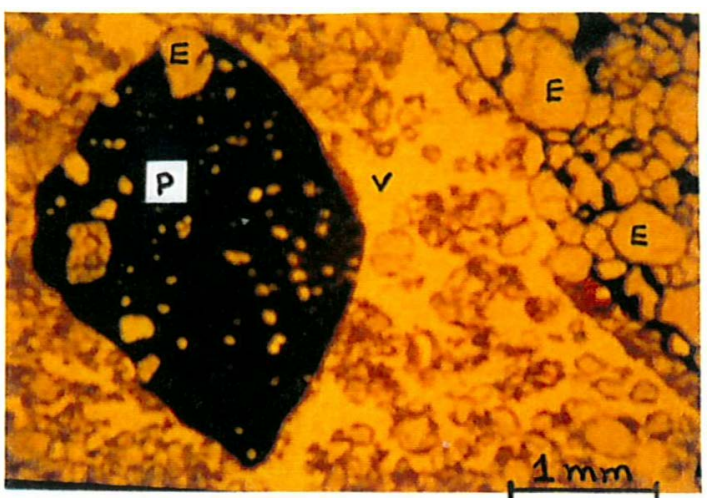

C

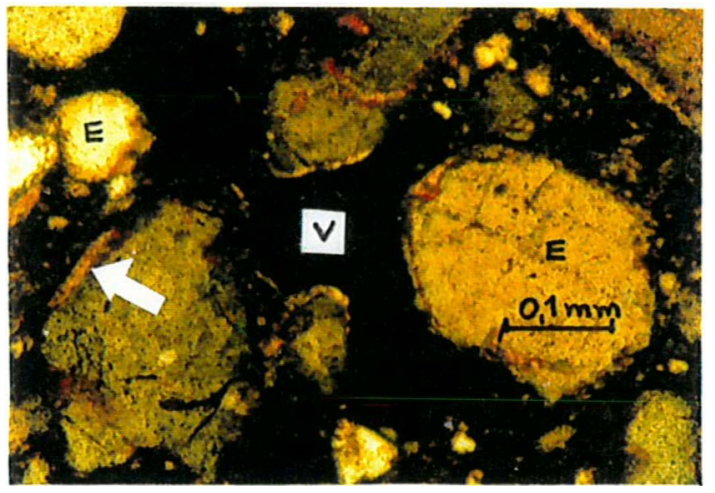

e

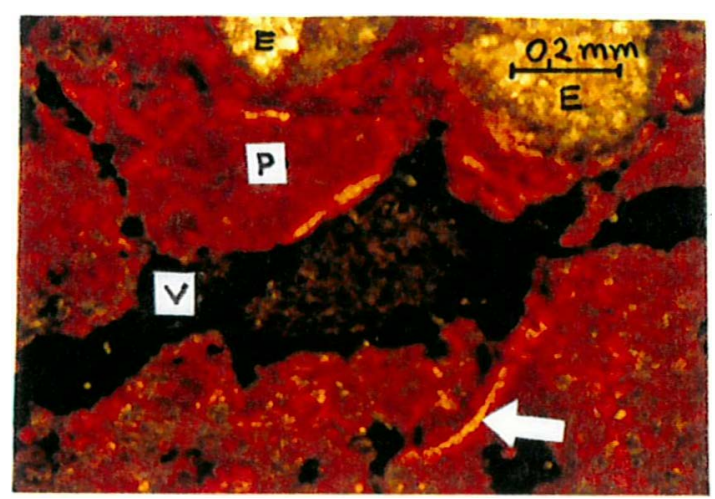

b

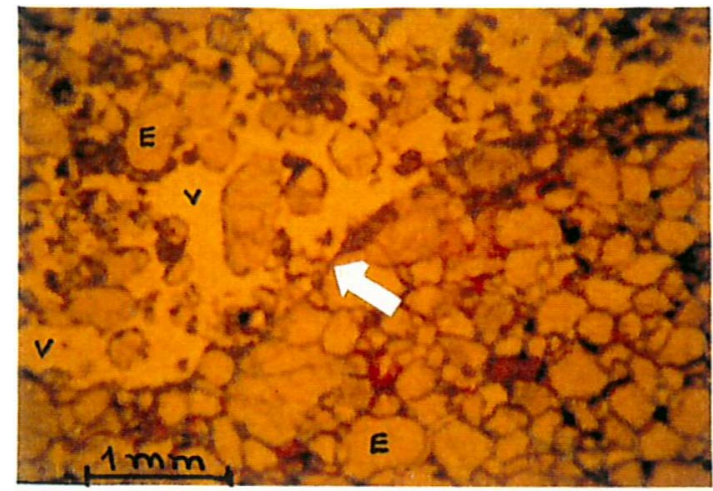

$d$

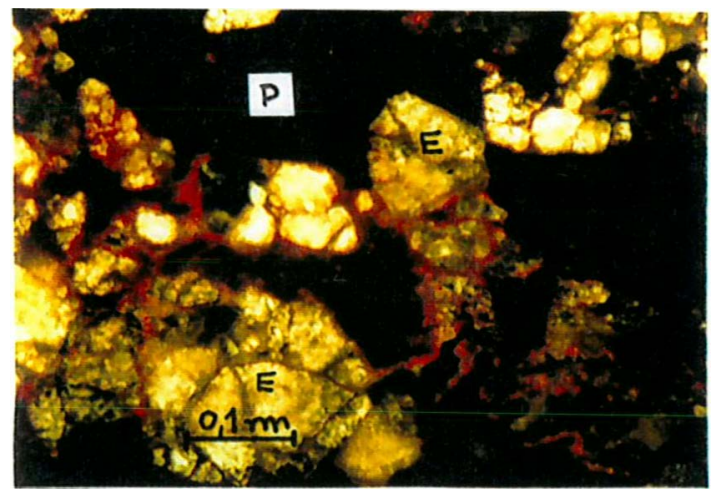

f

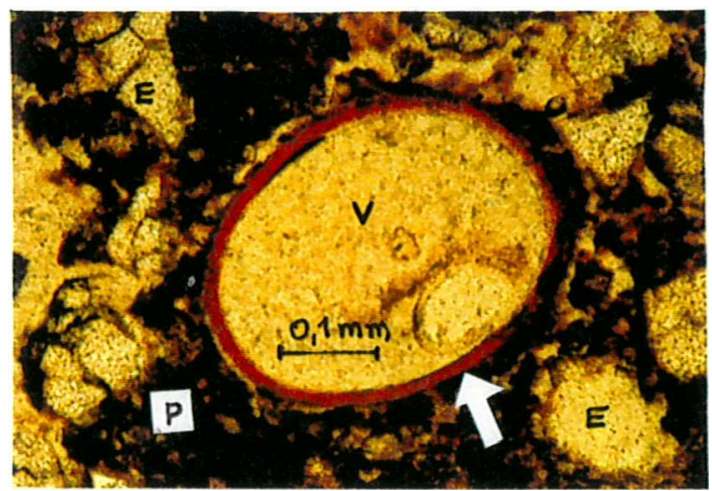

Figura 23 - Fotomicrografias dos solos moderamente desenvolvidos: a) nódulos ferruginosos da camada 35Cc (In); b) zona de contato entre as camadas 35Cc e 35Cr (In); c) separações plásmicas esquelssépicas do horizonte 12Bi (nc); d) fundo matricial da camada $12 \mathrm{~F}(\mathrm{nc})$; e) poro ortocavitário do horizonte $32 \mathrm{Cc}(\mathrm{nc}) ; \mathrm{f})$ poro com goetita formada na parede no horizonte $31 \mathrm{Ap}(\ln )$. 
Do ponto de vista físico, estes solos podem representar severas restrições ao desenvolvimento das raízes das plantas, devido à profundidade moderada (50 - 100 $\mathrm{cm}$ ), à camada petroplíntica endurecida no limite entre o solum e a alterita e ao impedimento temporário à condutividade hidráulica no contato entre estas camadas. $\mathrm{O}$ aumento da densidade do solo nos horizontes superficiais com relação às densidades subsuperficiais destes solos sugere que os mesmos sofrem de compactação, produzida provavelmente pelo manejo inadequado das pastagens, tais como carga animal inadequada, pastoreio em condições de alta umidade do solo e por períodos de tempo muito prolongados, práticas que devem adequar-se ao fato de que estes solos têm uma maior permanência da água que os outros solos.

Os dados químicos mostram que nestes solos também há uma estreita relação entre $\mathrm{pH}, \mathrm{C}$ orgânico, $\mathrm{V} \%$, teor de $\mathrm{P}$ e Alumínio assimilável, assim a uma diminuição do $\mathrm{C}$ orgânico em profundidade corresponde uma diminuição do $\mathrm{pH}$, do V\% e do P e um aumento considerável do Alumínio trocável.

A disponibilidade de nutrientes destes solos é muito baixa, sendo que a saturação por bases (V\%) é geralmente abaixo de $20 \%$ nos horizontes $\mathrm{Bi}$, porém, em alguns horizontes superficiais como nos horizontes 12A, 32Ap e 43Ap, os níveis de V\% chega a 24, 20 e $33 \%$, respectivamente. Acompanhando este comportamento das bases em profundidade, o fósforo também diminui consideravelmente desde $3-5 \mathrm{mg} / \mathrm{kg}$ na superfície até inclusive $1 \mathrm{mg} / \mathrm{kg}$ a maior profundidade, contrariamente à saturação por alumínio, a qual aumenta enormemente em profundidade desde valores de $10-67 \%$ nos horizontes superficiais até mais de $80 \%$ nas camadas mais profundas, como entre o horizonte Bi e a camada Cc do perfil 35.

Há grande diferença dos atributos mineralógicos entre as camadas $12 \mathrm{~F}$, $31 \mathrm{~F} 32 \mathrm{~F}, 43 \mathrm{Cc}$ e as demais camadas e horizontes no que se refere ao teor de $\mathrm{Fe}_{2} \mathrm{O}_{3}$, $\mathrm{TiO}_{2}$ e minerais leves/pesados. Os teores de $\mathrm{Fe}_{2} \mathrm{O}_{3}$ destas camadas variaram desde $4,42 \%$ na camada $32 \mathrm{~F}$ até $9,42 \%$ na camada $12 \mathrm{~F}$, em comparação aos valores de 0,73 , $0,29,1,99,0,98,4,30$ e 1,74, correspondentes aos horizontes $34 \mathrm{Bi}, 12 \mathrm{Bi}, 32 \mathrm{Bi}, 35 \mathrm{Bi}$, 
$43 \mathrm{Bi}$ e $31 \mathrm{Bi}$. Os valores de $\mathrm{TiO}_{2}$ aumentam geralmente de 60 a $160 \%$ a mais desde os horizontes $\mathrm{B}$ para as camadas $\mathrm{F}$ e/ou $\mathrm{Cc}$, com exceção do perfil 35 onde não há muita diferença tanto de $\mathrm{Fe}_{2} \mathrm{O}_{3}$ nem de $\mathrm{TiO}_{2}$ entre a camada $\mathrm{Cc}$ e os horizontes suprajacentes.

Os teores de $\mathrm{Fe}_{2} \mathrm{O}_{3}$ são concordantes com as cores mais avermelhadas das camadas $\mathrm{F}$ e $\mathrm{Cc}$, assim como também com o aumento de minerais pesados na fração areia fina, sugerindo que os mesmos foram concentrados pela água de infiltração suspensa sobre a camada $\mathrm{Cr}$.

Na Figura 24 são apresentados os difratogramas dos raios- $X$ da fração argila mais representativos destes solos e correspondentes aos horizontes $31 \mathrm{Bi}$ e $31 \mathrm{Cc}$, onde pode-se observar que ambos os horizontes apresentam picos correspondentes à espaçamentos de caulinita (3,5 e 7,0 angstrons nos tratamentos com $\mathrm{K}$ e com $\mathrm{Mg}$ a $\left.25^{\circ} \mathrm{C}\right)$, à espaçamentos correspondentes a vermiculita $(14,0$ angstrons nos tratamentos com $\mathrm{K}$, com $\mathrm{Mg}$ e com $\mathrm{Mg}$ glicolada a $25^{\circ} \mathrm{C}$ ) e à espaçamentos correspondentes a mica (3,3; 5,0 e 10,0 angstrons nos tratamentos com $\mathrm{K}$ e com $\mathrm{Mg}$ a $25^{\circ} \mathrm{C}$ ).

Segundo o "Soil Taxonomy" todos estes solos foram classificados dentro da ordem dos "Inceptisols" devido à presença de horizonte diagnóstico subsuperficial câmbico e não reunirem requisitos referidos as ordens dos Avidiasols e Moltisols.

O perfil 12 foi classificado como Cambissolo álico petroplíntico $\mathrm{Tb} \mathrm{A}$ proeminente, textura média, fase floresta subtropical subperenifolia, substrato quartzito, relevo ondulado, o qual não apresenta nem rochosidade, nem pedregosidade, tendo uma drenagem moderada pela presença da camada laterítica $F$ a $85 \mathrm{~cm}$ de profundidade, declive de $7 \%$, sob uso pastoril e com erosão laminar moderada.

O perfil 34 foi classificado como Cambissolo álico Ta A moderado, textura média, fase floresta subtropical subperenifolia, substrato quartzito, relevo ondulado, o qual apresenta rochosidade em grau forte, mas sem pedregosidade, sendo acentuadamente drenado, declive de $7 \%$, sob uso pastoril e/ou florestal e com erosão forte e laminar. 

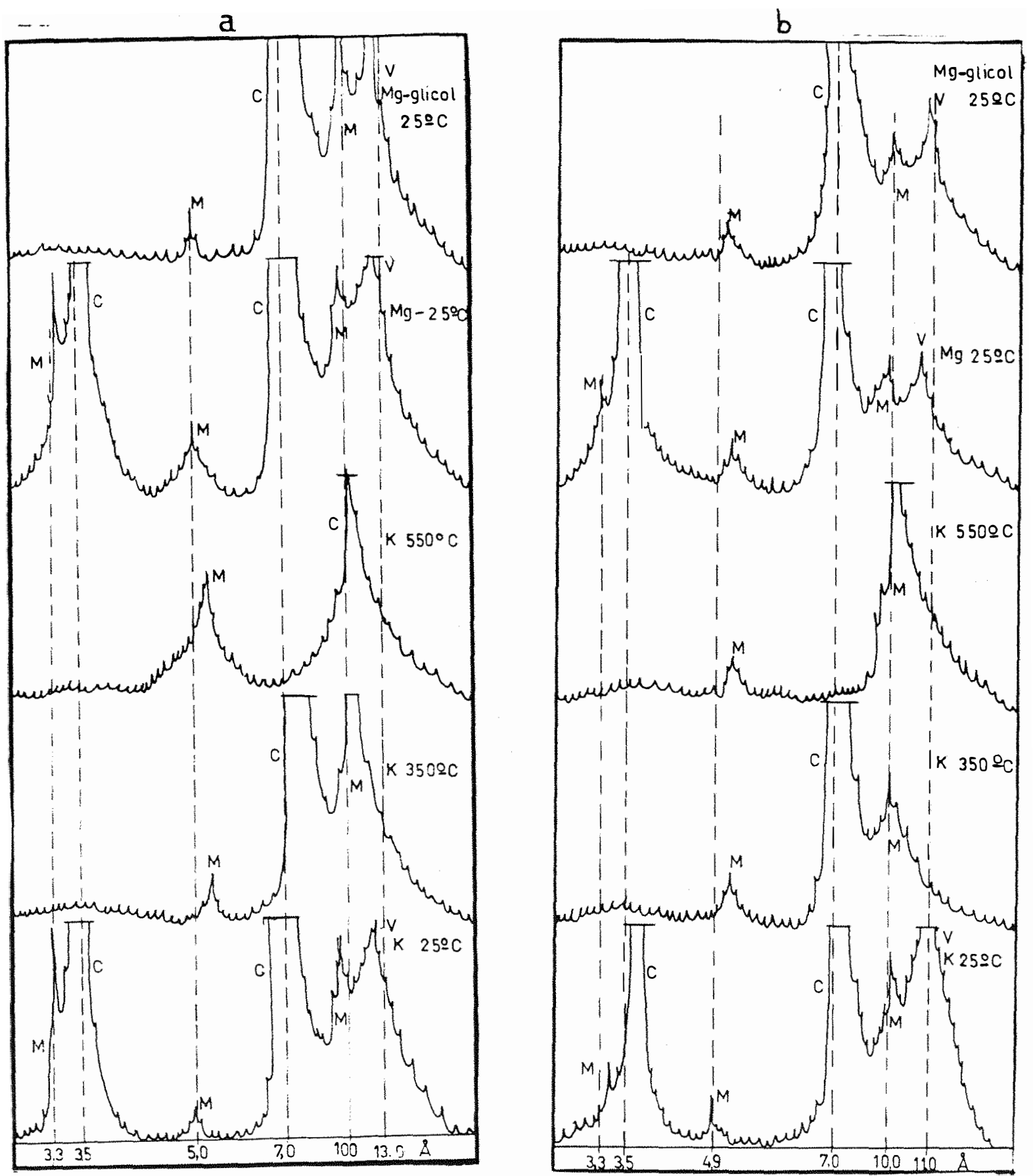

Figura 24 - Difratogramas dos raios X da fração argila dos solos moderadamente desenvolvidos: a) horizonte $31 \mathrm{Bt}$; b) camada $31 \mathrm{Cc}$. C: caulinita: M: mica: $\mathrm{V}$ : vermiculita. 
Os perfís 31 e 32 foram classificados como Plintossolo pétrico álico Ta A moderado, textura média ou média/argilosa, fase floresta subtropical subperenifolia, substrato de quartzito, relevo ondulado; pertencendo o perfil 35 a mesma classe mas com a diferença de possuir um horizonte A proeminente, sendo todos moderadamente drenado, sem rochosidade nem pedregosidade, declives de 6-9\%, sob uso pastoril e com erosão laminar moderada.

O perfil 43 foi classificado como Plintossolo pétrico álico $\mathrm{Tb} A$ moderado, textura médio/argilosa, fase floresta subtropical subperenifolia, substrato de quartzito, relevo ondulado, sendo moderadamente drenado, sem rochosidade nem pedregosidade, declives de $6 \%$ e com erosão laminar moderada.

\subsubsection{Solos bem desenvolvidos}

Os solos bem desenvolvidos (perfis 21, 22, 30, 41, e 44) têm uma seqüência de horizontes $\mathrm{AABBtCCr}, \mathrm{ABtCcCr}$ e $\mathrm{AEBt}$, sendo os de menor profundidade os perfís 21 e $44(180 \mathrm{~cm})$, enquanto que os demais solos ultrapassaram a profundidade de $2 \mathrm{~m}$ (perfís 41, 22 e 30) ainda que por poucos $\mathrm{dm}$, tendo IDP que variam desde 43,0 no perfil 21 até 71,7 no perfil 44 .

A espessura do horizonte A varia de $40 \mathrm{~cm}$ no perfil 44 até $110 / 150 \mathrm{~cm}$ no perfil 41 , sendo que a espessura do horizonte Bt varia desde $55 \mathrm{~cm}$ no perfil 21 até $100 \mathrm{~cm}$ no perfil 30. O perfil 41 apresenta um horizonte E álbico de $40 \mathrm{~cm}$ de espessura que se inicia a $130 / 140 \mathrm{~cm}$ de profundidade e os perfís 30 e 44 têm diferentes graus de desenvolvimento de uma camada concressionária $\mathrm{Cc}$, que no perfil 30 tem uma espessura de $20 \mathrm{~cm}$, enquanto que no perfil 44 tem maior espessura ( > $50 \mathrm{~cm}$ ).

A transição entre os horizontes superficiais e subsuperficiais é geralmente gradual, plana ou ondulada, sendo que a transição entre os horizontes Bt e as camadas subjacentes $\mathrm{Cc}, \mathrm{F}$ ou $\mathrm{Cr}$ é quase sempre abrupta e descontínua. 
A cor (úmida) dos horizontes superficiais varia de bruno escuro (7.5 YR 3/2) a bruno avermelhado escuro (5 YR 3/3) e nos subsuperficiais desde bruno forte (7.5 YR 4/6) até vermelho escuro (2.5 YR 3/6), sendo que as camadas concressionárias apresentam uma cor avermelhada (2.5 YR 3/6) e as camadas $\mathrm{Cr}$ variam desde amarelo brunado (10 YR 6/8) a amarelo avermelhado (5 YR 6/8) e rosado (5YR 7/4).

Na Tabela 4 são apresentados os resultados das observações micromórficas realizadas nas lâminas destes solos e na Figura 25 algumas fotomicrografias mais representativas dos mesmos.

Os maiores graus de desenvolvimento de agregados e superfícies brilhantes foram observados nestes solos, atingindo o grau forte de desenvolvimento de agregados de blocos subangulares em alguns horizontes $\mathrm{Bt}$, como é o caso dos horizontes Bt do perfil 44, sendo que a maior expressão de superfícies brilhantes encontra-se nos horizontes 22Bt2 e 44Bt, apesar de que as lâminas delgadas não mostraram evidência de argiluviação, só cutãns de contração e difusão (Figuras 25b,f) e agregação variando de poliédricos a microgranulares (Figura 25c,d), esqueleto comumente moderado a mal selecionado (Figura 25a), plasma esquelssépica a vossépica (Figura 25b) ou bimassépica (Figura 25d).

O único perfil que apresentou argila iluviada foi o perfil 22, ainda que localizada nos poros da camada $22 \mathrm{Cr}$, sendo este solo também o de maior relação textural $\mathrm{B} / \mathrm{A}=2,3 \mathrm{e}$ forte desenvolvimento de grandes agregados poliédricos subangulares, enquanto que as separações plásmicas (cutãns) observadas em todas as lâminas de todos estes solos (Figuras 25b,f), sugerem que os solos sofreram "stress" devido mais provavelmente às condições do clima da região caracterizado por períodos quentes e úmidos (verão) alternados com períodos frios e secos (inverno).

A consistência dos horizontes $\mathrm{A}$ varia desde macio, friável, não plástico nem pegajoso no $41 \mathrm{Ap}$ até ligeiramente duro, friável, ligeiramente plástico e ligeiramente pegajoso no horizonte 30Ap, enquanto que a consistência dos horizontes 
Bt varia desde ligeiramente duro, muito friável, plástico e ligeiramente pegajoso no $21 \mathrm{Bt} 2$ até muito duro, friável, plástico e pegajoso no $30 \mathrm{Bt} 2$.

Estes solos apresentam maior variabilidade enquanto a estrutura do perfil e presença de nódulos ferruginosos, assim nos horizontes $\mathrm{A}$ e $\mathrm{E}$ do perfil 41 não encontraram-se nódulos ferruginosos (Figura 25a), enquanto que nos perfís 21 e 22 observou-se poucos nódulos irregulares em todo o perfil (Figura 25c) e nos perfís 44 e 30 há a formação de uma camada concressionária $\mathrm{Cc}$, sendo tal camada de maior expressão no 44 Cc (Figura 25e), variações que podem ter relação com as posições que os solos ocupam no relevo, as quais são também muito variáveis, desde topos (perfil 30), encostas (perfil 21), concavidades (perfil 41) e sopés (perfís 22 e 44).

Estes solos são os que apresentaram também o maior desenvolvimento dos horizontes superficiais, tanto em espessura como em conteúdo de carbono orgânico, tendo os horizontes A mais escurecidos (melanizados), assim o perfil 41 apresentou o horizonte A mais espesso $(130-140 \mathrm{~cm})$ com teores de 8,7 a $11,6 \mathrm{~g} / \mathrm{Kg}$ de carbono orgânico, caracterizando A proeminente, seguido pelos perfis $30 \mathrm{~A}(90 \mathrm{~cm}) ; 22 \mathrm{~A}(80 \mathrm{~cm})$; $21 \mathrm{~A}(60 \mathrm{~cm})$ e $44 \mathrm{~A}(40 \mathrm{~cm})$ com diversos teores de $\mathrm{C}$ orgânico, tendo o horizonte 44 Al o maior teor $(17,9 \mathrm{~g} / \mathrm{kg})$, sendo todos estes últimos horizontes definidos como A moderado.

Todos estes solos apresentaram também uma estreita relação entre teor de carbono orgânico, disponibilidade de fósforo, saturação por bases, $\mathrm{pH}$ e alumínio trocável com a profundidade. Assim com a diminuiçāo do carbono orgânico e do pH em profundidade, observa-se uma diminuiçāo das bases e do fósforo disponível e um aumento do alumínio em profundidade, sendo os perfís 22 e 30 distróficos, enquanto que os demais são todos álicos e com baixa saturação por bases (6 a 27\%) e alta saturação com alumínio, desde $27 \%$ no horizonte $22 \mathrm{Btl}$ até $61 \%$ no horizonte 22BC. 


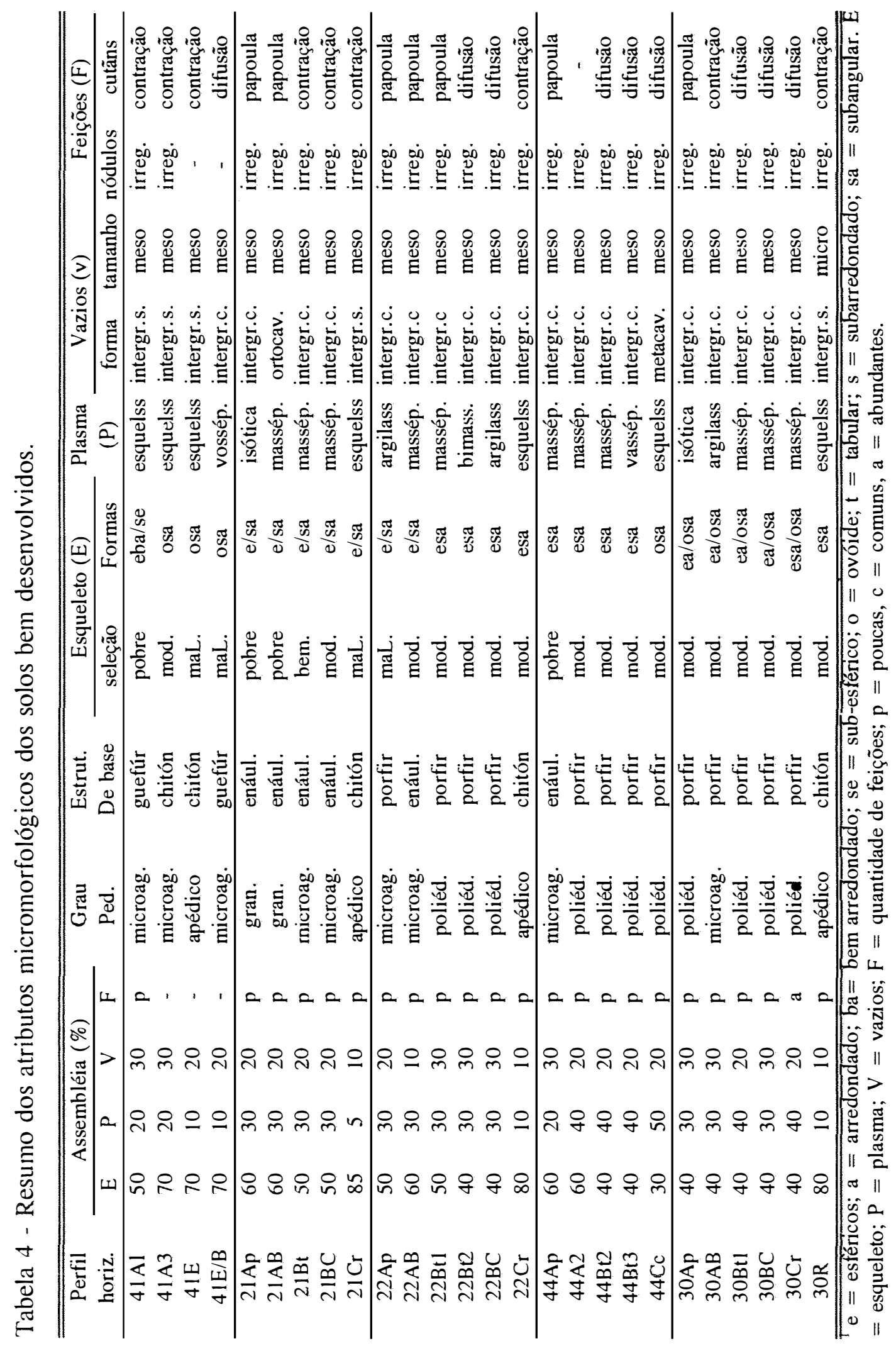


a

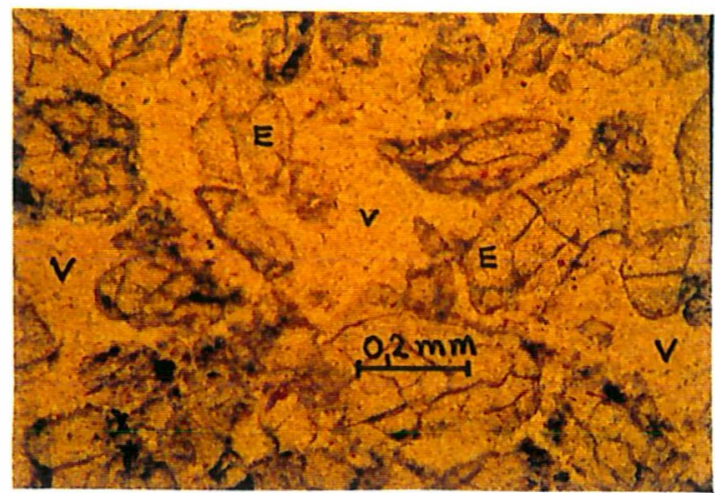

c

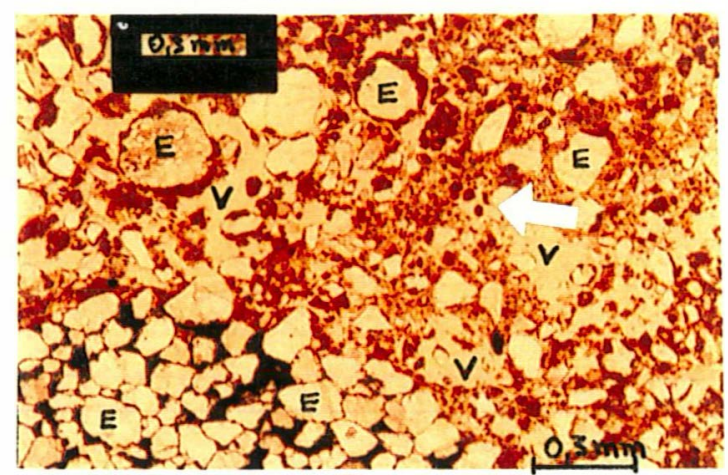

e

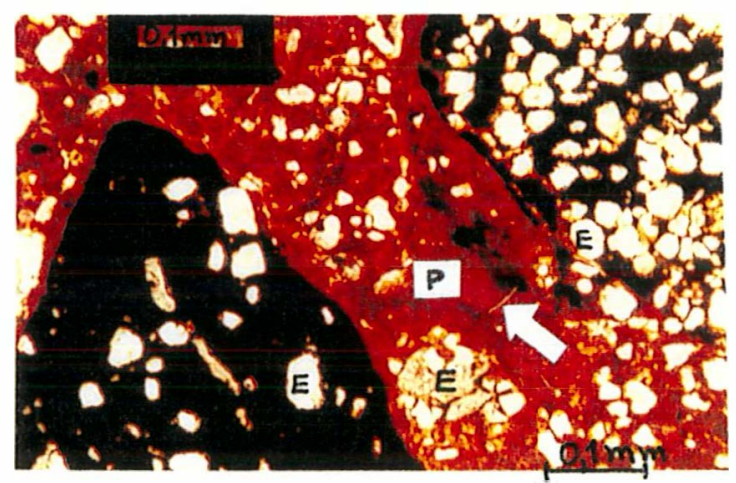

b

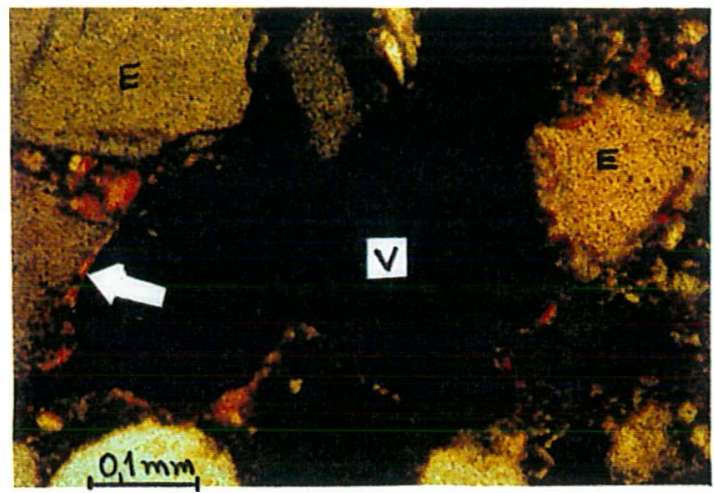

$d$

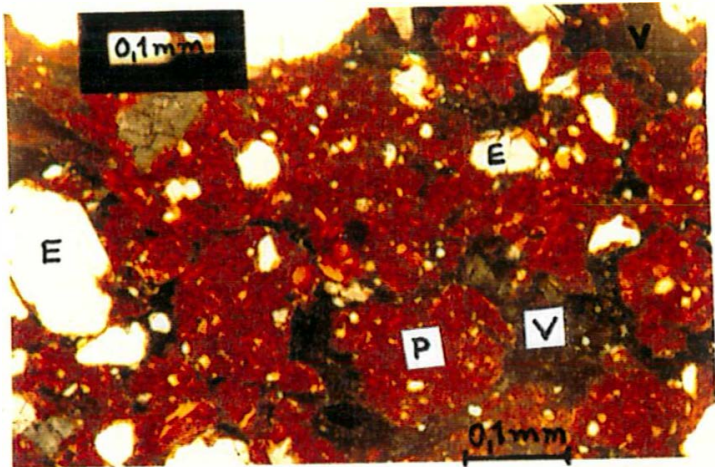

f

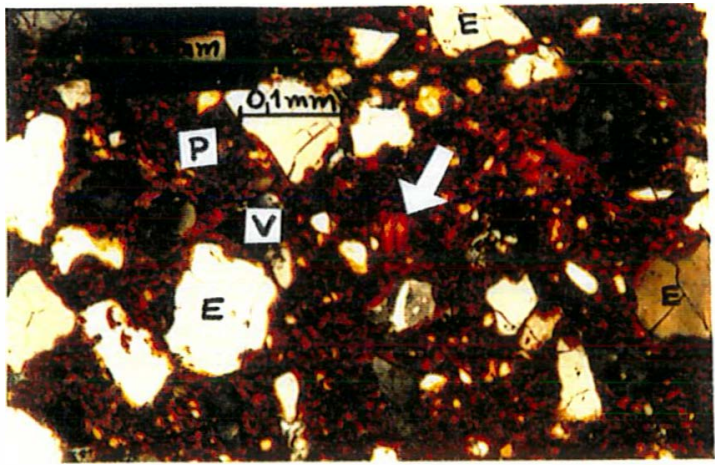

Figura 25 - Fotomicrografias dos solos bem desenvolvidos: a) fundo matricial do horizonte $41 \mathrm{E}(\ln )$; b) poro ortocavitário no $41 \mathrm{E} / \mathrm{B}$ (nc); c) microagregados e nódulo do $21 \mathrm{Bt}(\mathrm{ln})$; d) microagregados adensados do $22 \mathrm{Bt} 2$ (nc); e) nódulos ferruginosos e microporos goetitizando na camada 44Cc $(\ln )$; f) plasma despigmentando com cutãns de difusão no 30Bt (nc). 
Similarmente aos solos moderadamente desenvolvidos, alguns destes solos apresentam importantes incrementos de $\mathrm{Fe}_{2} \mathrm{O}_{3}$ (óxidos férricos) com a profundidade, desde 0,2 a 0,54\% entre os horizontes 41 Ap e 41E/B e de 1,72 a 10,4\% entre os horizontes $44 \mathrm{Ap}$ e $44 \mathrm{Cc}$, sendo que os teores $\mathrm{Ti} \mathrm{O}_{2}$ (óxidos de titânio) variaram muito pouco com a profundidade, enquanto que os principais argilominerais da fração argila destes solos estão constituídos também por caulinita, vermiculita e mica (Figura 26).

Todos estes solos foram classificados como Podzólicos Vermelhos Amarelos segundo o sistema proposto por Camargo et al. (1987), considerando a presença do horizonte argílico ou $\mathrm{B}$ textural, que foi identificado pela presença de cerosidade e pela relação textural entre os horizontes $\mathrm{B} / \mathrm{A}$, ainda que as lâminas delgadas nao evidenciaram processos de argiluviação.

Segundo o "Soil Taxonomy" estes solos entram na ordem dos "Ultisolos" e não na ordem dos "Alfisols", devido a apresentarem horizonte argílico e saturação por bases < $35 \%$ em profundidade, a $125 \mathrm{~cm}$ abaixo do topo do horizonte argílico ou kândico ou $180 \mathrm{~cm}$ abaixo da superfície do solo ou no contato lítico, para-lítico ou petroférrico.

O perfil 21 foi classificado como Podzólico Vermelho-amarelo álico Tb A moderado textura medio/argilosa, fase floresta subtropical subperenifolia, substrato arenito, relevo ondulado, tendo uma relação textural $\mathrm{B} / \mathrm{A}=2,4$ que passa de franco arenoso no horizonte Ap com $160 \mathrm{~g} / \mathrm{kg}$ de argila e $110 \mathrm{~g} / \mathrm{kg}$ de silte para argila arenosa no horizonte Bt2 com $390 \mathrm{~g} / \mathrm{kg}$ de argila e $80 \mathrm{~g} / \mathrm{kg}$ de silte.

O perfil 22 foi classificado como Podzólico Vermelho-amarelo distrófico Tb A moderado textura média/argilosa, fase floresta subtropical subperenifolia, substrato arenito, relevo ondulado e apresentando uma textura que passa de franco arenoso na superfície, com $140 \mathrm{~g} / \mathrm{Kg}$ de argila e $150 \mathrm{~g} / \mathrm{Kg}$ de silte, a argilo-arenosa no horizonte $\mathrm{Bt} 2$, onde chega a ter até $450 \mathrm{~g} / \mathrm{Kg}$ de argila e $90 \mathrm{~g} / \mathrm{Kg}$ de silte. 
a

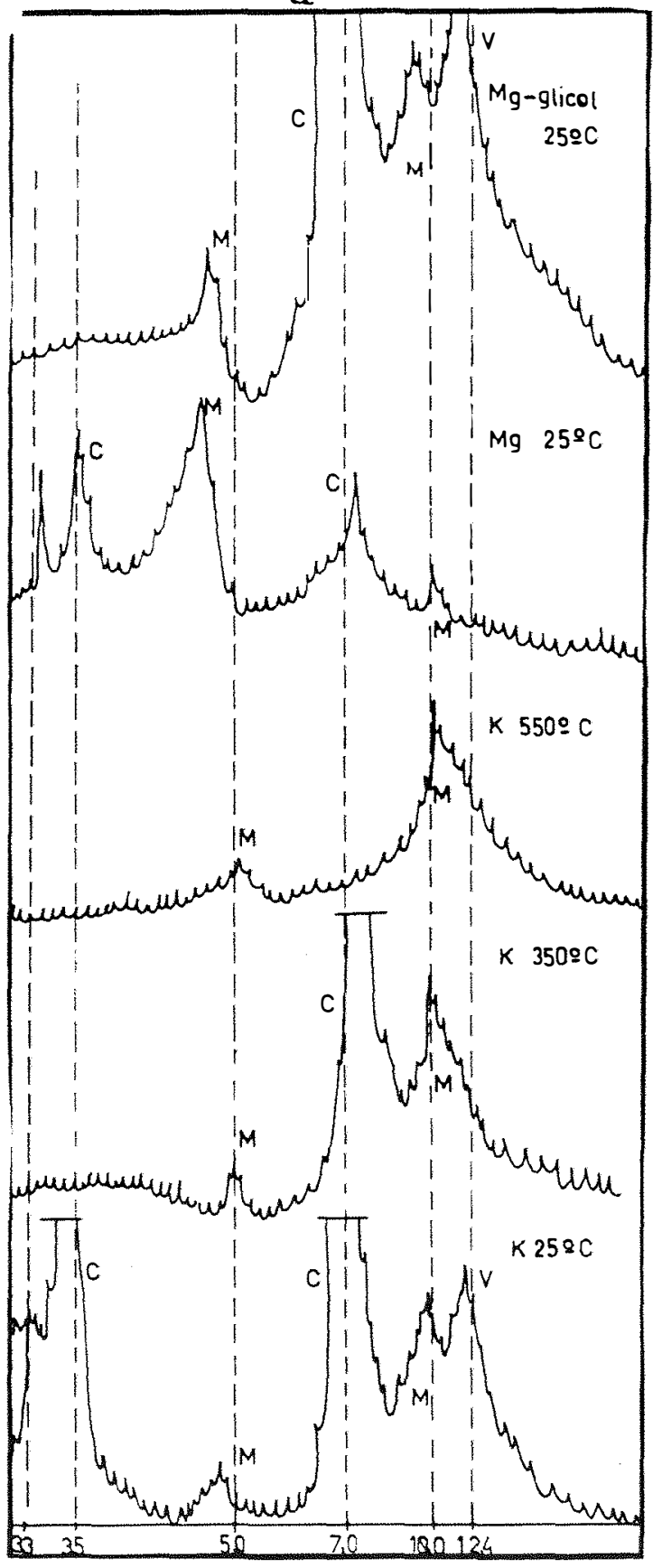

b

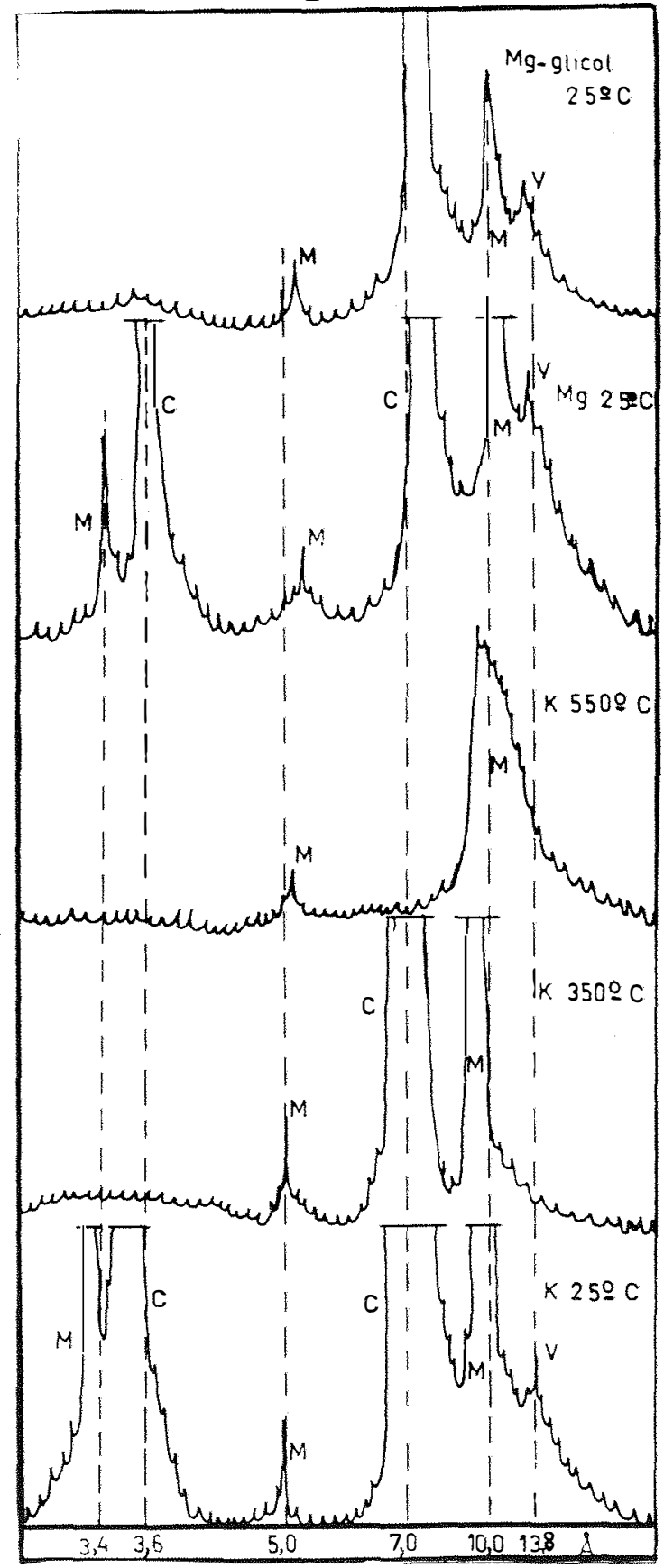

Figura 26 - Difratogramas dos raios-X da fração argila dos solos bem desenvolvidos: a) Horizonte $30 \mathrm{Bt} 2$; b) horizonte $30 \mathrm{Cr}$. C: caulinita; M: mica; V: vermiculita. 
O perfil 41 foi classificado como Podzólico Vermelho-amarelo álico plíntico $\mathrm{Tb}$ A proeminente textura arenoso/media, fase floresta subtropical subperenifolia, substrato arenito, relevo forte ondulado, apresentando uma textura areia franca na superfície com $80 \mathrm{~g} / \mathrm{Kg}$ de argila e $40 \mathrm{~g} / \mathrm{Kg}$ de silte, passa a franco arenoso em profundidade com $150 \mathrm{~g} / \mathrm{Kg}$ de argila e $40 \mathrm{~g} / \mathrm{Kg}$ de silte, com um horizonte $\mathrm{E}$ álbico de textura areia (Figura 25a) com $60 \mathrm{~g} / \mathrm{Kg}$ de argila e $40 \mathrm{~g} / \mathrm{Kg}$ de silte (a cor úmida deste neste solo varia de bruno escuro com notação 7.5 YR 3/3 no horizonte A3 para bruno com notação 7.5 YR 5/4 no horizonte E e para bruno com notação 7.5 YR 5/4 no horizonte E/B.

Os perfís 30 e 44 não apresentam razão textural entre os horizontes $\mathrm{B} / \mathrm{A}$ suficiente para caracterizar um Bt, mas em campo observou-se cerosidade moderada e comum localizada nos canais e superfícies dos agregados, porém, todos eles apresentaram moderado a alto grau de dispersão de argila natural nos horizontes superficiais, com valores de até $67 \%$ de dispersão no horizonte $30 \mathrm{~A} 2$ e de $60 \%$ no horizonte $41 \mathrm{E}$.

O perfil 30 foi classificado como Podzólico Vermelho-amarelo petroplíntico distrófico $\mathrm{Tb}$ A moderado textura médio/argilosa, fase floresta subtropical subperenifolia, sustrato arenito, relevo plano.

O perfil 44 foi classificado como Podzólico Vermelho-amarelo álico petroplíntico $\mathrm{Tb}$ A moderado textura médio/argilosa, fase floresta subtropical subperenifolia, substrato arenito, relevo ondulado.

\subsubsection{Solos fortemente desenvolvidos}

Os solos fortemente desenvolvidos estão constituídos pelo perfil 13 que têm uma seqüência de horizontes e camadas $A A B B w B w f F$ e pelo perfil 42 que tem uma seqüência $\mathrm{AABBwC}$, os quais apresentaram também os valores mais altos de IDP, sendo de 68,4 no perfil 13 e de 94,4 no perfil 42 . 
A espessura dos horizontes superficiais (incluindo o horizonte transicional $\mathrm{AB}$ ) destes solos é de $100 \mathrm{~cm}$, enquanto que os horizontes $\mathrm{Bw}$ tem pouca variação, de 70-80 cm, com transição gradual e plana entre os horizontes $\mathrm{A}, \mathrm{AB}$ e Bw. As maiores diferenças morfológicas entre estes solos é que o perfil 13 tem um horizonte plíntico Bwf sobre uma camada laterítica $F$, enquanto que o perfil 42 não apresenta tal seqüência de horizontes e tem uma profundidade que ultrapassa os $3 \mathrm{~m}$.

A cor do horizonte A varia de bruno escuro (7.5 YR 3/2, úmido) no perfil 13, a bruno avermelhado escuro (5 YR 3/4, úmido) no perfil 42 , enquanto que a cor (úmida) dos horizonte $B$ varia de bruno forte (7.5 YR 4/6) no perfil 13 a vermelho escuro (2.5 YR 3/6) no perfil 42, sendo a cor da camada 13F vermelho escuro acinzentado.

A capacidade de agregação é geralmente fraca a moderada, granular nos horizontes A e moderada e forte, média a grande de blocos subangulares no horizonte Bw e Bwf. A consistência do horizonte 13A é macio, friável, não plástico nem pegajoso e no 42A ligeiramente duro, friável, ligeiramente plástico e ligeiramente pegajoso, enquanto que no horizonte 13Bw é macio, muito friável, ligeiramente plástico e ligeiramente pegajoso e no $42 \mathrm{Bw}$ é duro, muito friável, ligeiramente plástico e pegajoso.

Na Tabela 5 é apresentado um resumo dos atributos micromórficos destes solos e na Figura 27 algumas fotomicrografias dos mesmos. Todas as lâminas dos horizontes Bw mostraram microagregados (Figura 27a,b,c,f) e em ambos os solos, foi observado no campo, fraco e pouco desenvolvimento de superfícies brilhantes, localizadas nos canais, poros, superfícies de grãos e fazendo ponte entre os grãos de areia dos horizontes $\mathrm{B}$, mas as lâminas delgadas revelaram que estas superfícies brilhantes estão constituídas por cutãns de contração e difusão e não por filmes originados por argiluviação (Figura 27d,e).

Em ambos os solos observou-se a presença de nódulos ferruginosos, pequenos e irregulares, ainda que em pouca quantidade, assim como estruturas de base porfíricas que vão transformando-se para enáulicas (Figura 27a,b), com agregados 
poliédricos que se desfazem em microagregados (Figura 27c,f) e plasma mormente esquelssépica que mostram cutãns de contração descontínuas e messoporos intragranulares compostos (Figura 27e).

Nota-se também, ainda que secundariamente, poros ortocavitórios e fissurais (Figura 27a,c), e esqueleto mal selecionado em todo o perfil (Figura 27a,f). A Figura $27 \mathrm{~d}$ pertence ao interior de um mosqueado vermelho escuro (provavelmente plintita) do horizonte 13 Bwf na qual observa-se os cutãns de difusão (provavelmente goetita) formados na parede do poro, mostrando que neste solo ocorrem processos de hidromorfismo temporário com perdas de ferro e transformações dos argilominerais (ferrólisis).

A classe textural no perfil 13 é franco argilo-arenoso, mas o teor de argila varia com a profundidade e fica no limite para ter gradiente textural, sendo sua relação textural $\mathrm{B} / \mathrm{A}=1,6$, aumentando de $200 \mathrm{~g} / \mathrm{kg}$ de argila e $110 \mathrm{~g} / \mathrm{kg}$ de silte no horizonte $\mathrm{A} 1$ até $330 \mathrm{~g} / \mathrm{kg}$ de argila e $100 \mathrm{~g} / \mathrm{kg}$ de silte no horizonte Bwf, enquanto que no perfil 42 a textura passa de franco argilo-arenosa com $220 \mathrm{~g} / \mathrm{kg}$ de argila e $80 \mathrm{~g} / \mathrm{kg}$ de silte no horizonte Al para argila arenosa com $370 \mathrm{~g} / \mathrm{kg}$ de argila e $120 \mathrm{~g} / \mathrm{kg}$ de silte no horizonte Bw2.

O teor de C orgânico do perfil 13 ( $16 \mathrm{~g} / \mathrm{kg}$ de solo) e sua profundidade ( $>18 \mathrm{cms}$ ) permitem classificá-lo como A proeminente, enquanto que o horizonte $42 \mathrm{~A}$ tem $15,6 \mathrm{~g} / \mathrm{kg}$ de $\mathrm{C}$ orgânico e cor requerida (valor igual ou menor que 3 em úmido), mas com espessura não suficiente, sendo portanto um $\mathrm{A}$ moderado.

Os dois solos têm baixa saturação por bases, menor de $20 \%$ no horizonte B, alta saturação por alumínio ( $>50 \%$ ) e pH baixos $(5,2$ a 4,7). O perfil 42 apresentou uma diminuição em profundidade de $\mathrm{P}$ assimilável, $\mathrm{C}$ orgânico, pH e CTC, acompanhado por um aumento da saturação por alumínio, enquanto que o perfil 13 tem um ligeiro aumento do $\mathrm{pH}$ com a profundidade, pouca variação da CTC e diminuição do P assimilável e do C orgânico. 


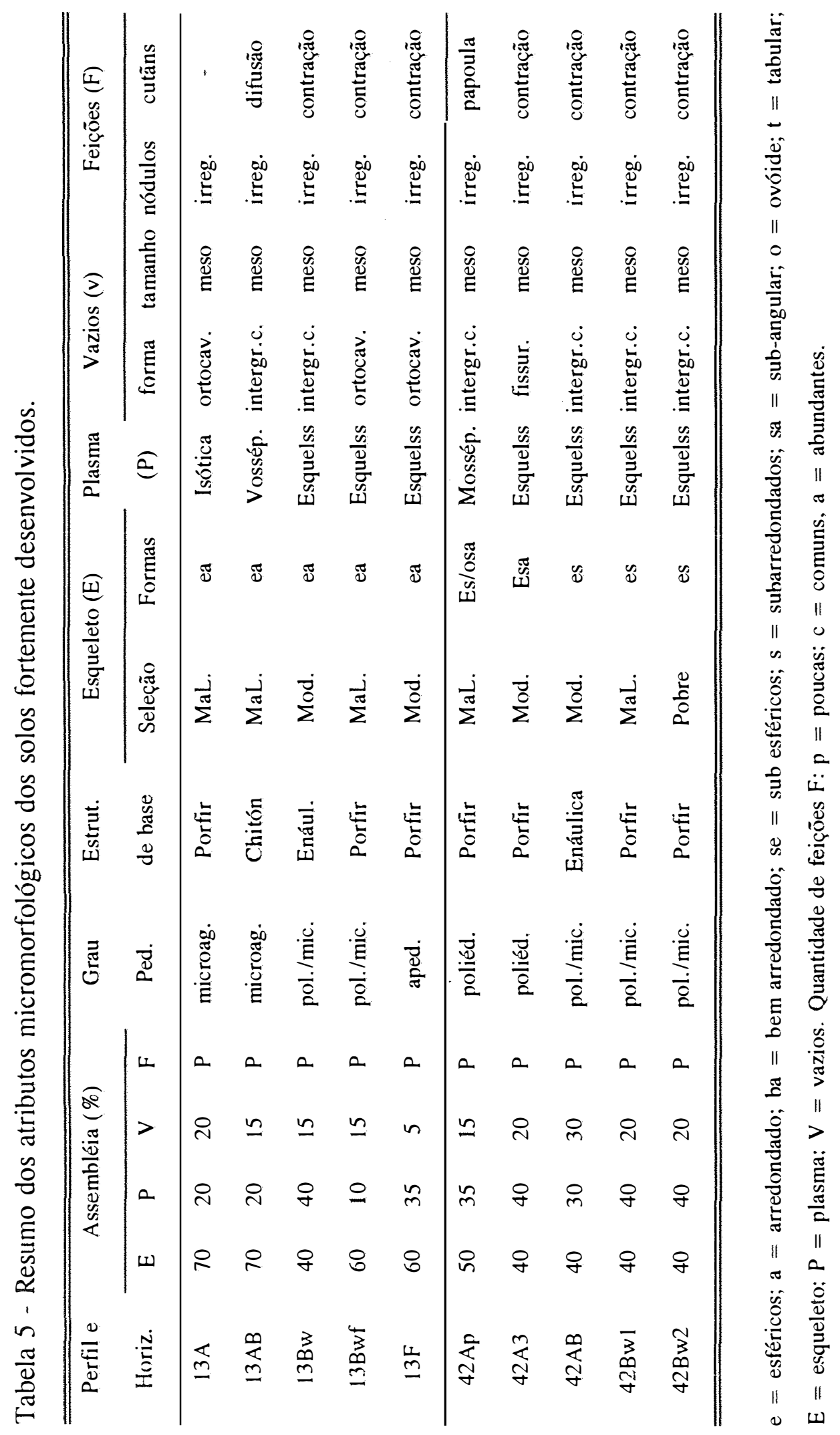


a

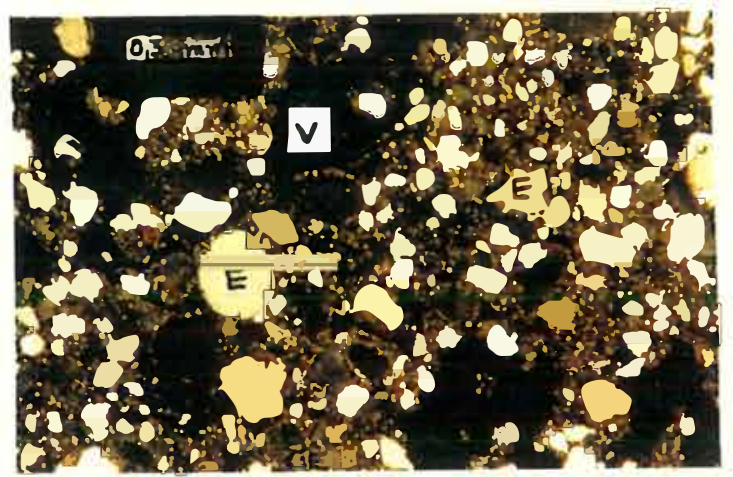

C

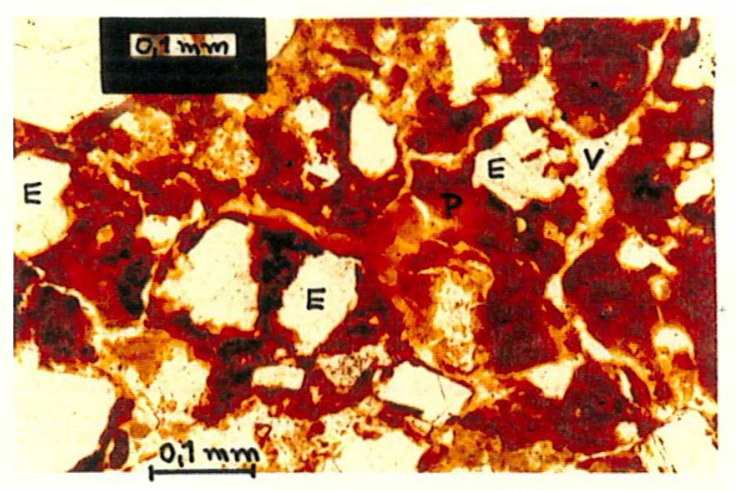

e.

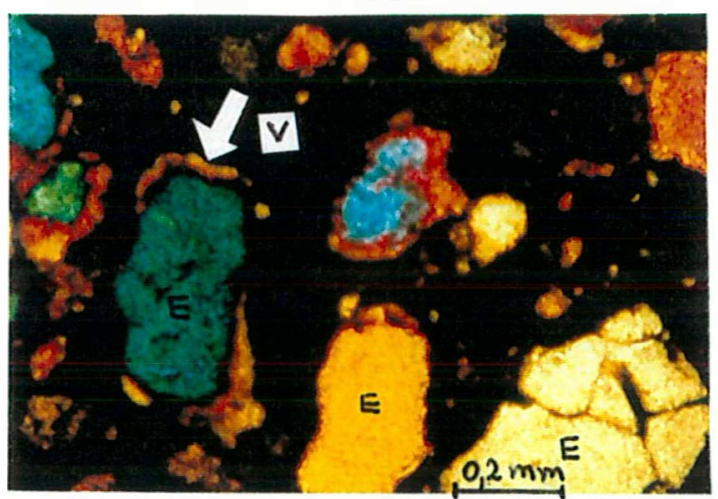

b

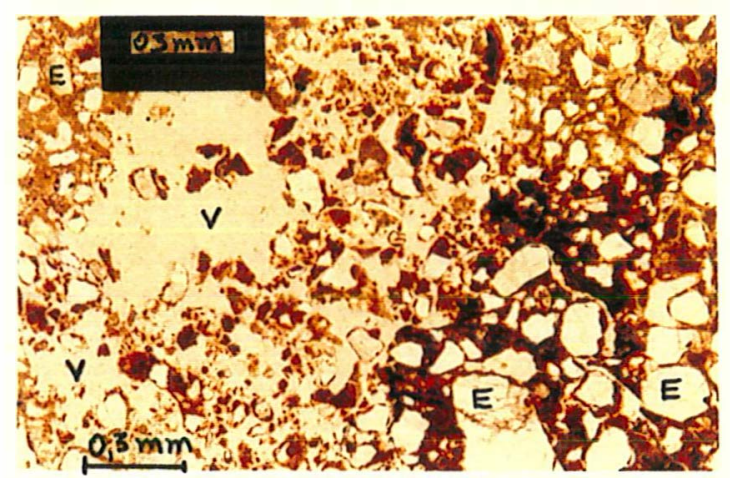

$d$

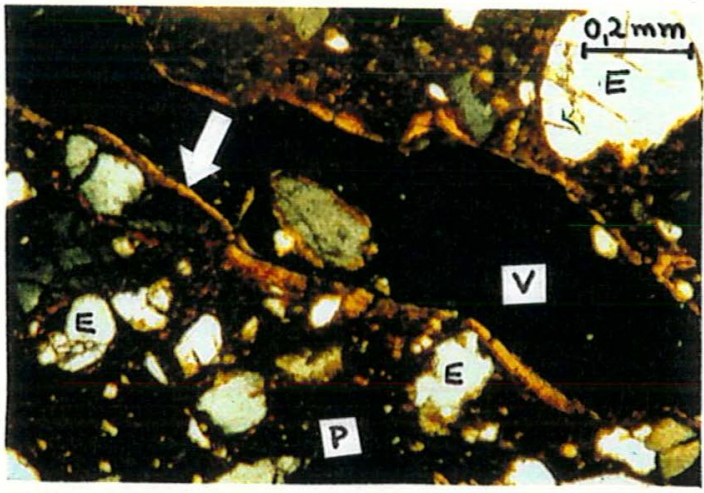

$f$

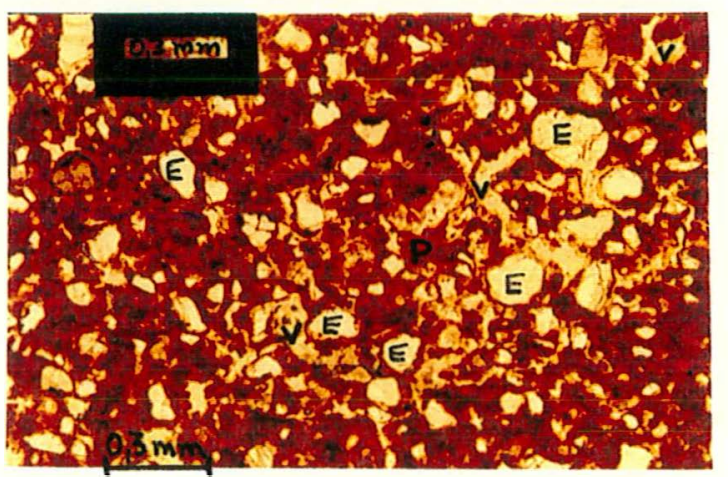

Figura 27 - Fotomicrografias dos solos fortemente desenvolvidos: a) poros ortocavitários do horizonte $13 \mathrm{Bw}(\mathrm{nc})$; b) reliquia de nódulo do horizonte $13 \mathrm{Bwf}$ (In); c) microagregados do horizonte $13 \mathrm{Bwf}(\ln )$; d) poro dentro de uma plintita com goetita nas paredes, horizonte 13 Bwf (nc); e) plasma esquelssépica horizonte $42 \mathrm{~A} 3$ (nc); f) microagregados no horizonte $42 \mathrm{Bw}(\ln )$. 
Por outro lado, as condições físicas destes solos podem ser consideradas excelentes, tendo boa porosidade e agregação, ainda que o fluxo de água possa ter impedimento para uma boa percolagem vertical em profundidade e em nível da base do solo, como é o caso do perfil 13 que tem uma camada petroplíntica importante (F) a $1,8 \mathrm{~m}$ de profundidade, assim como no perfil 42 que mostrou a presença do lençol freático flutuante após vários dias ter chovido, o que sugere que a camada de impedimento (provavelmente petroplintita) encontrar-se-ia neste solo a uma maior profundidade $(>3 \mathrm{~m})$.

O perfil 13 apresentou baixo teor de $\mathrm{Fe}_{2} \mathrm{O}_{3}$ nos horizontes $\mathrm{A}$ e $\mathrm{B}, 0,54$ e $0,90 \%$, respectivamente, aumentando para $18,16 \%$ na camada $F$, enquanto que no perfil 42 o $\mathrm{Fe}_{2} \mathrm{O}_{3}$ varia de $2,07 \%$ na superfície até $4,48 \%$ no horizonte Bw2. O índice $\mathrm{Ki}$ é mais alto no horizonte $13 \mathrm{Bw}(\mathrm{Ki}=2,1)$ que no horizonte $42 \mathrm{Bw} 2(\mathrm{Ki}=1,79)$, o que demostra que este último seja mais intemperizado que o perfil 13.

Na Figura 28 são apresentados os difratogramas dos raios-X da fração argila dos horizontes $42 \mathrm{AB}$ e $42 \mathrm{Bw}$, os quais mostram picos correspondentes à espaçamentos de caulinita, vermiculita e mica, enquanto que os difratogramas dos raios-X da fração silte (não apresentado) mostraram picos correspondentes a quartzo e a pirofilita.

O perfil 13 foi classificado como Latossolo Vermelho-amarelo álico plíntico A proeminente textura média, fase floresta subtropical subperenifolia, substrato quartzito, relevo ondulado, sendo bem a moderadamente drenado, sem rochosidade nem pedregosidade, declive de 7 a $10 \%$ e erosão laminar e em sulcos em grau moderado.

$\mathrm{O}$ perfil 42 foi classificado como Latossolo Vermelho-Amarelo álico A moderado textura média/argilosa, fase floresta subtropical subperenifolia, substrato quartzito, relevo ondulado, sendo bem drenado, sem rochosidade nem pedregosidade, declives de $6 \%$ e erosão laminar ligeira. Segundo o "Soil Toxonomy" estes solos deveriam ser incluídos na ordem dos 'Ultisols', não tendo o requisito de $16 \mathrm{cmol} / \mathrm{kg}$ de argila ou menos para ser considerado como horizonte diagnóstico óxico. 

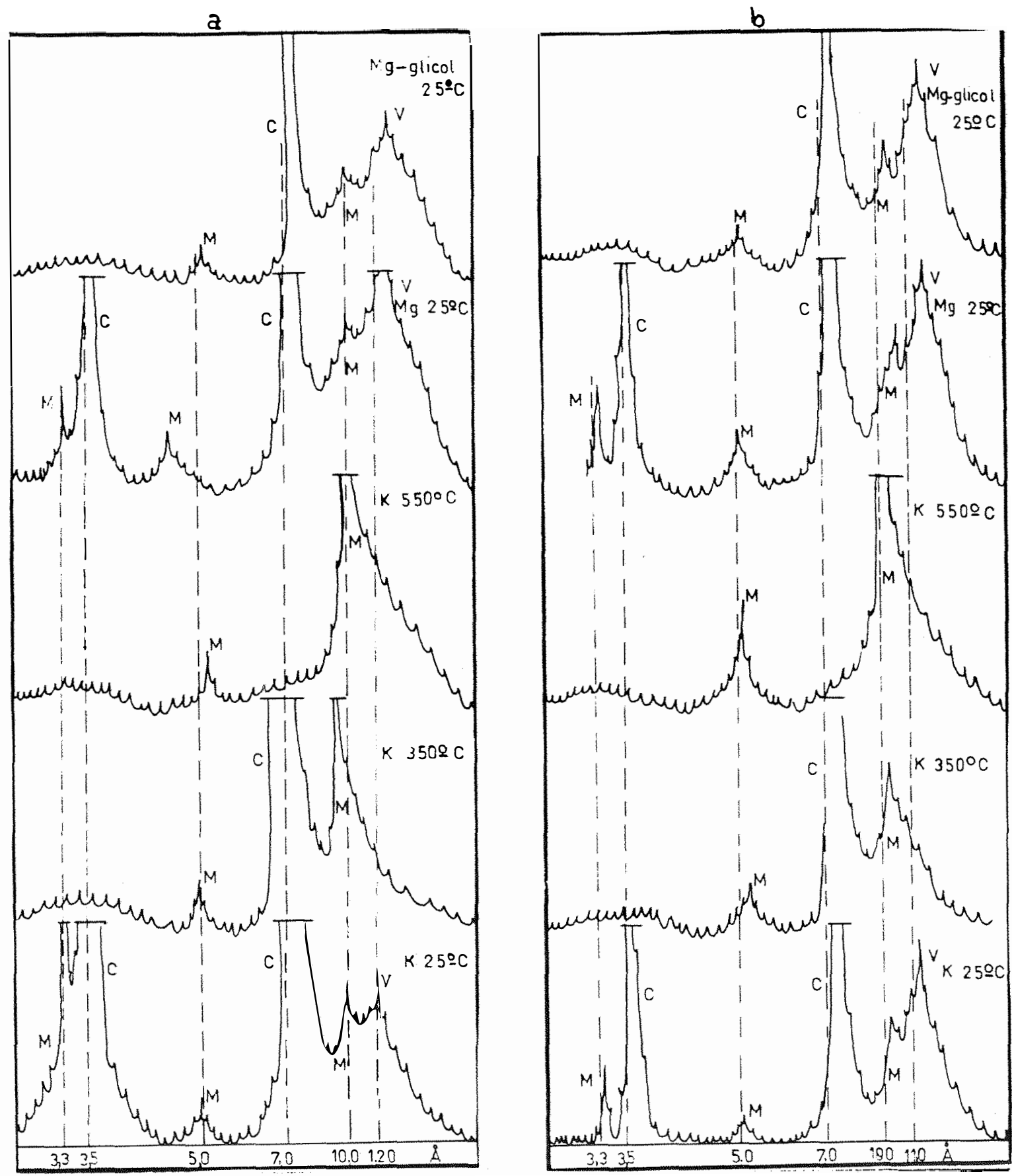

Figura 28 - Difratogramas do raio-X da argila dos solos fortemente desenvolvidos: a) Horizonte $42 \mathrm{AB}$ : b) Horizonte $42 \mathrm{Bw}$. C: caulinita; M: mica; V: vermiculita. 
Os principais dados utilizados para incluir estes solos na classe latossol são: a) espessura $>50 \mathrm{~cm}$; b) CTC após deduçāo da contribuição do carbono orgânico $<130 \mathrm{mmol} / \mathrm{kg}$ de solo; c) índice $\mathrm{Ki}<2,2$; d) relação silte/argila $<0,7$; d) se presentes na fração areia fina menos de $4 \%$ de minerais facilmente intemperizáveis; e) $<5 \%$ por volume de fragmentos de rocha ou saprolito; f) agregação forte muito pequena e pequena granular a blocos subangulares moderada; g) gradiente textural no sólum não satisfazendo requisitos de B textural; e h) exclusão de características de processos de redução e plintização referidos, respectivamente, a horizontes glei e plíntico (Camargo et al., 1987).

\subsection{Toposequiência de solos}

\subsubsection{Toposeqüência convexa}

As toposeqüências convexas podem ser encontradas principalmente nas colinas convexas e preferencialmente com orientação Leste, tendo-se descritos os solos que ocorrem nas posiçōes topográficas representativas e factíveis de serem separadas com a fotointerpretação, apresentando-se na Figura 29 o perfil de uma toposeqüência convexa, com as características dos respectivos solos.

Na parte mais elevada do relevo (topo), com declives de 1-3\%, ocorre um Regossolo álico Ta A moderado textura arenosa, moderadamente profundo (60-70) e fortemente drenado, sendo que no terço médio da vertente, com declives de 3-6\% ocorre um Podzólico Vermelho amarelo álico Tb A moderado textura média/argilosa, profundo $(2 \mathrm{~m})$ e bem drenado, enquanto que no terço médio, com declives de 10-15\% ocorre um Podzólico Vermelho Amarelo distrófico Tb A moderado textura médio/argilosa, profundo $(2 \mathrm{~m})$ e também bem drenado.

O comportamento em profundidade do teor de argila, do C orgânico, do teor de areia fina e da relação Ti/Zr nas diferentes posições topográficas é apresentado na Figura 30, onde pode-se observar que a quantidade de argila no solo aumenta com 


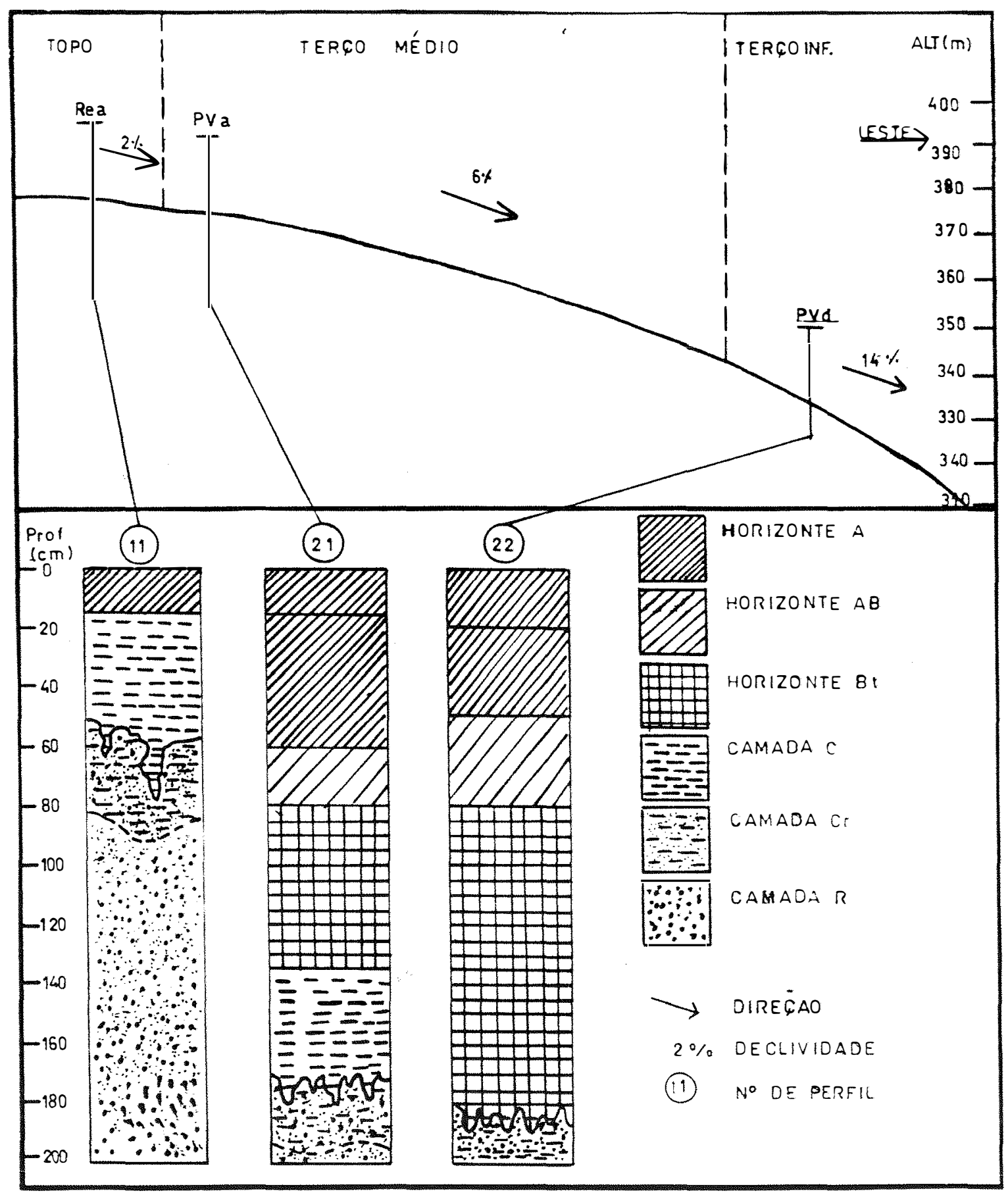

Figura 29 - Distribuição dos solos nas diferentes posições da toposeqüência convexa. P: podzólico: Re: regossolo; V: vermelho amarelo; á: álico. 
a b
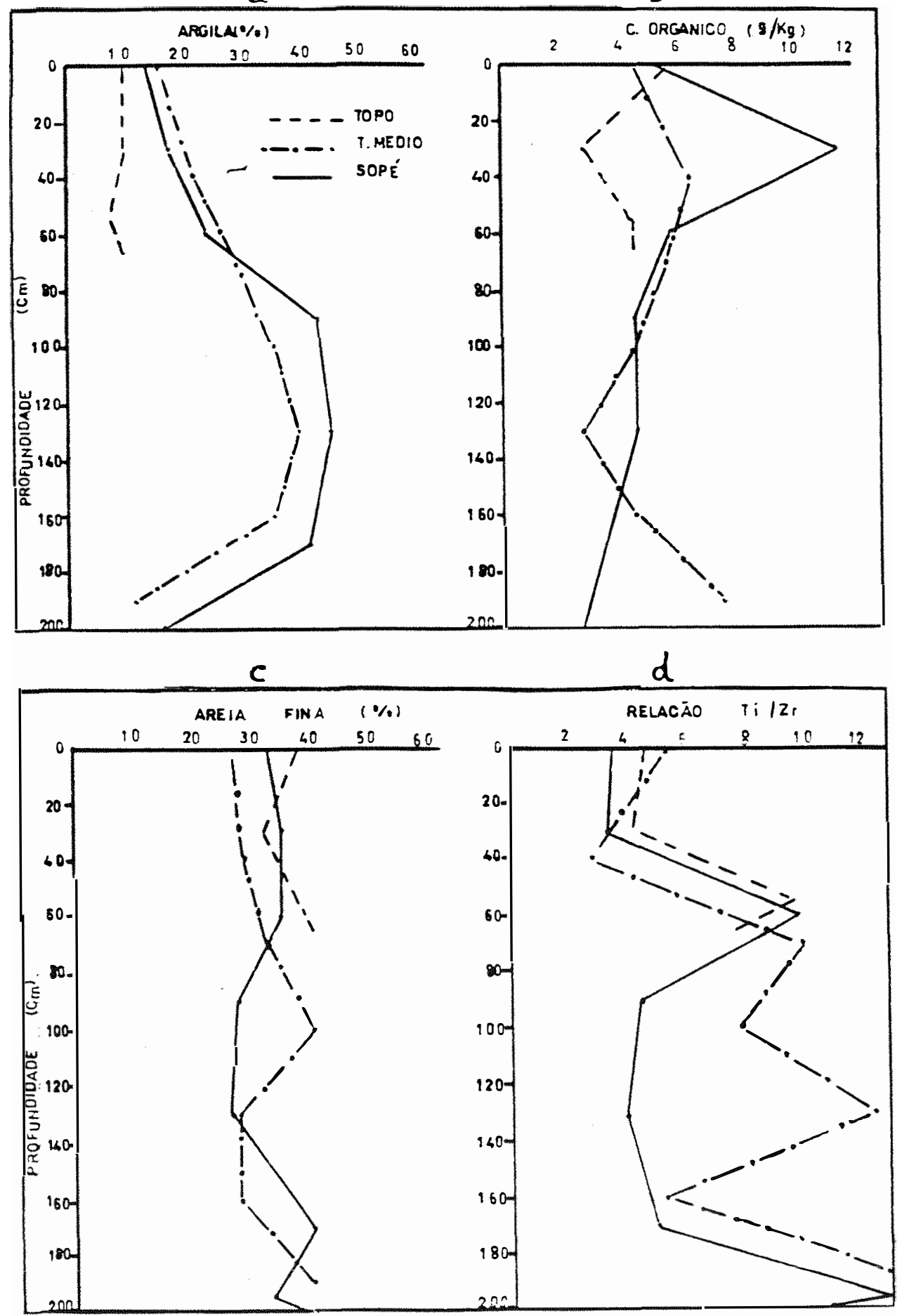

Figura 30 - Distribuição em profundidade da argila (a), do C orgânico (b) da areia fina (c) e da relação $\mathrm{Ti} / \mathrm{Zr}$ (d) nos solos da toposeqüência convexa. 
a profundidade dos solos localizados nos terços médio e inferior (sopé), havendo também diferença entre ambos os solos e ocorrendo uma maior quantidade de argila no horizonte subsuperficial $(\mathrm{Bt})$ do podzólico localizado no terço inferior.

$\mathrm{O}$ comportamento do $\mathrm{C}$ orgânico também varia com a profundidade e com a posição (Figura 30b), diminuindo com a profundidade em todos os solos como é de se esperar, mas observa-se que nos solos localizados nos terços médio e inferior há um aumento aos 30-40 cm, antes de diminuir consideravelmente em maior profundidade, sugerindo que a superfície do horizonte A pode ter sido recoberto por material coluvial.

O comportamento da areia fina em profundidade mostrou-se muito pouco variável, não havendo muita diferença entre os solos, mas sim observou-se que a quantidade de areia fina em superfície diminui no terço médio e aumenta novamente no terço inferior, enquanto que o comportamento da relação Ti/Zr em profundidade e com relação à posição topográfica não foi muito diferente, mostrando sim uma tendência de aumentar com a profundidade nos três solos.

\subsubsection{Toposeqüência convexo-linear}

As toposeqüências com forma superficial convexo-linear podem ser encontradas principalmente nas colinas convexas, e predominantemente nas vertentes com orientação Oeste, ilustrando-se na Figura 31 as características morfológicas dos solos de acordo com as respectivas posições da toposeqüências localizadas na vertente Oeste da colina convexa, situada ao Norte de "César Barrientos".

No terço superior (topo) e com declives de 1-3\% ocorre um Regossolo álico Ta A moderado textura arenosa, moderadamente profundo $(60-70 \mathrm{~cm})$ e fortemente drenado (perfil 11).

No ombro desta toposeqüência, onde o declive muda de 4 até $5 \%$, ocorre um Cambissolo álico petroplíntico Tb A proeminente textura média, moderadamente 


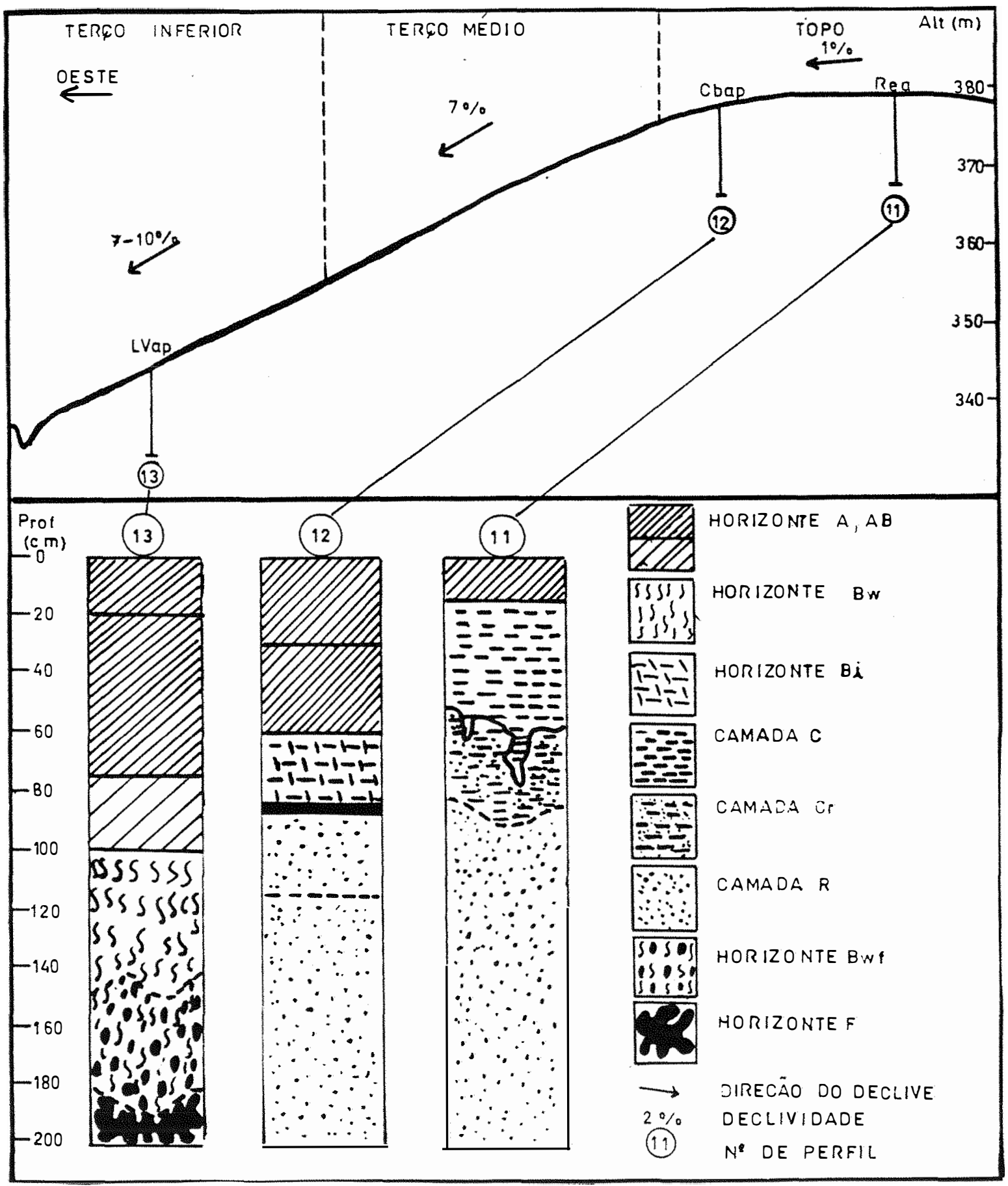

Figura 31 - Distribuição dos solos na toposeqüência linear com orientação Oeste da colina convexo-linear. Re: Regossolo; Cb: Cambissolo; L: Latossolo; p: plíntico; V: vermelho-amarelo; á: álico. 
a

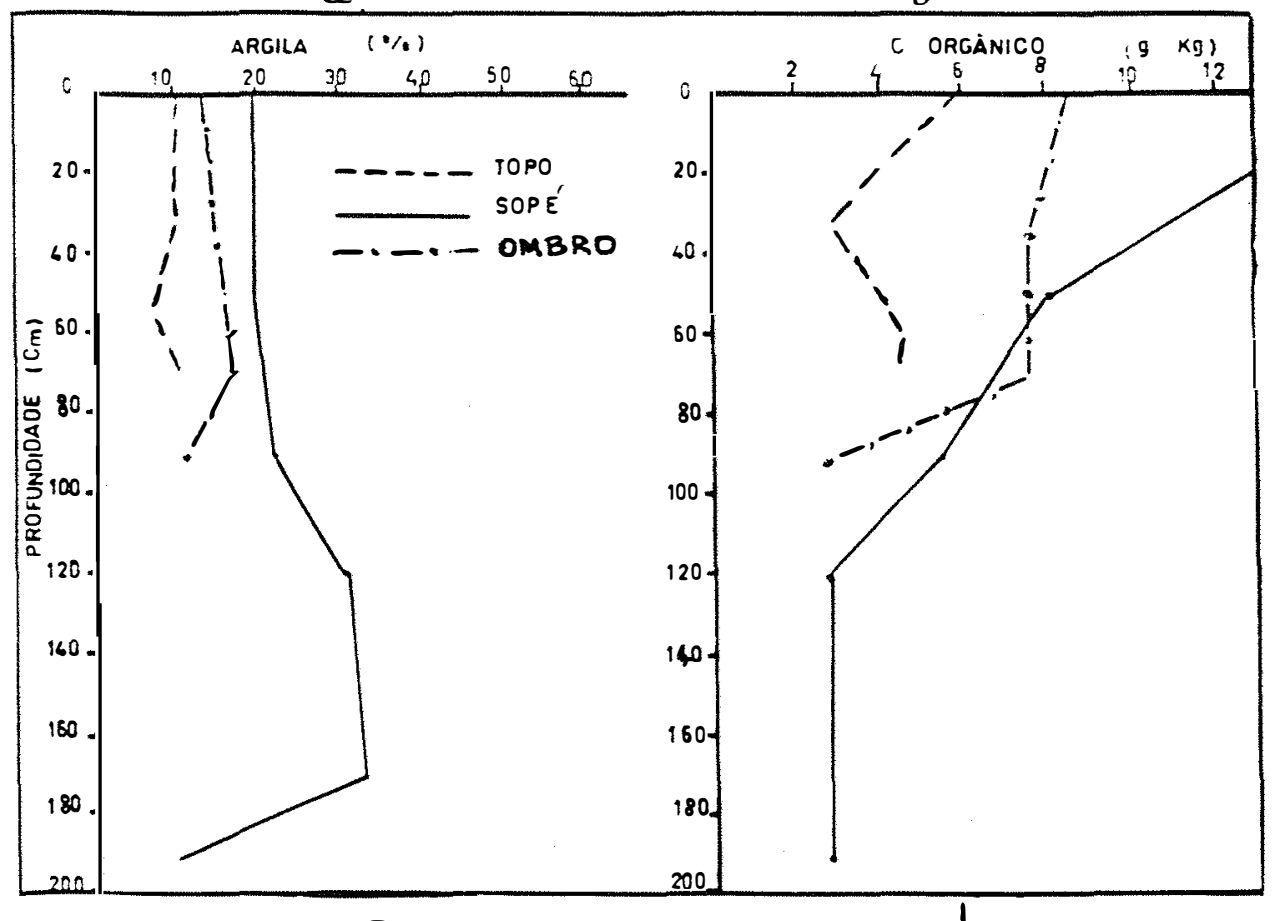

99

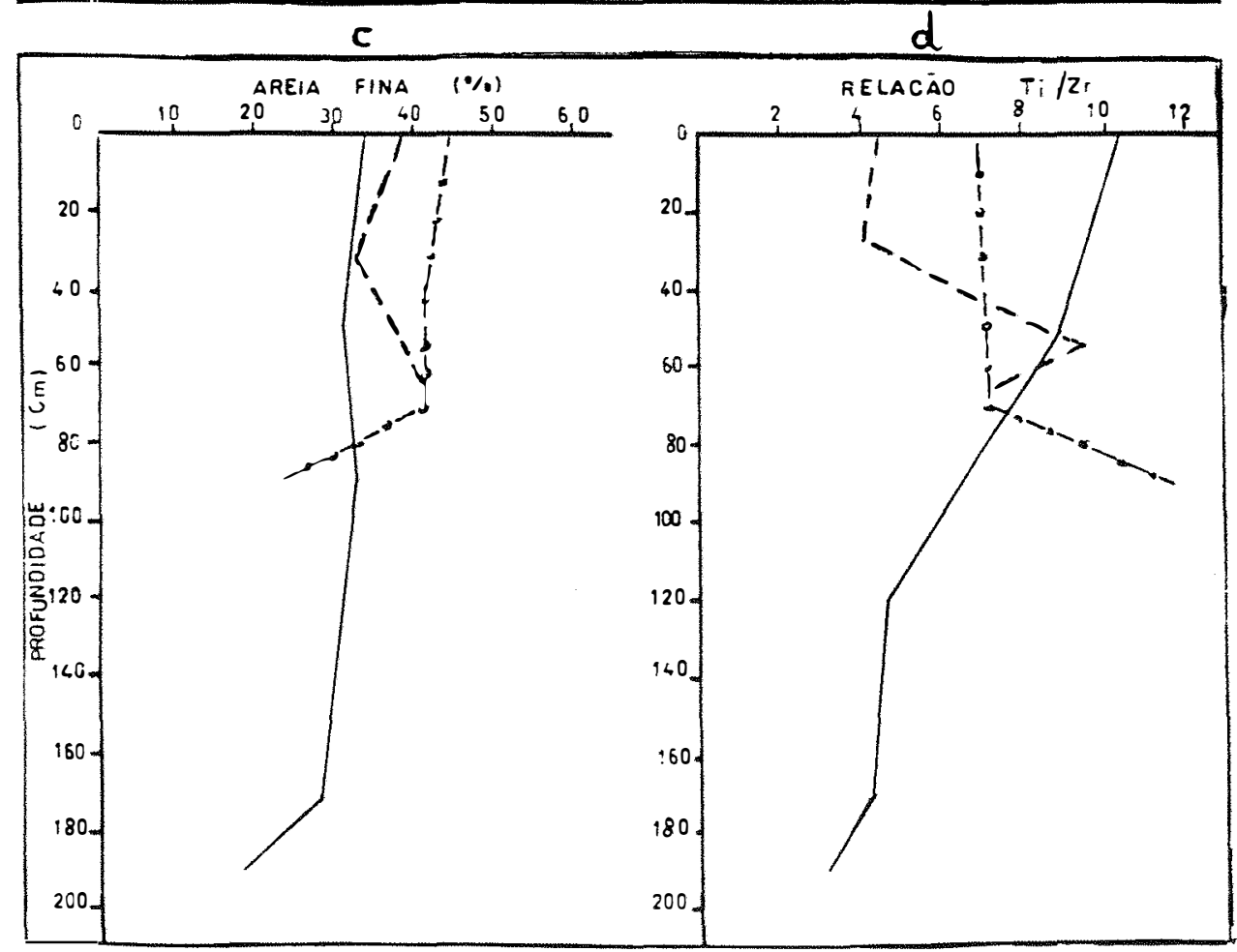

Figura 32 - Distribuição em profundidade da argila (a); do C orgânico (b); da areia fina (c) e da relação Ti/Zr (d) nos solos da toposeqüência convexo-linear com orientação Oeste. 
profundo $(85 \mathrm{~cm})$ e com drenagem impedida pela presença de uma camada petroplíntica de $2 \mathrm{~cm}$ de espessura no limite entre o solum e a alterita. As tradagens efetuadas no terço médio mostraram que a espessura deste solo aumenta à juzante e que também, além da presença de nódulos de petroplintita que aumenta em profundidade, existe um escalonamento da camada $\mathrm{Cr}$.

No terço inferior onde o declive é de $6 \%$, ocorre um cambissolo álico $\mathrm{A}$ proeminente textura média, profundo $(180-190 \mathrm{~cm})$ e com drenagem impedida pela presença de uma camada petroplintica entre o solum e a alteria, sobre a qual formou-se um horizonte plíntico característico.

O comportamento com a profundidade do teor de argila, do C orgânico, do teor de areia fina e da relaçāo $\mathrm{Ti} / \mathrm{Zr}$ nas diferentes posiçōes topográficas é apresentado na Figura 32.

$\mathrm{O}$ aumento de argila em profundidade destes solos mostrou que variou com a posiçāo topográfica, o que pode-se observar na Figura 32a, verificando-se um ligeiro aumento no solo situado no ombro (Cambissolo) e um aumento bem marcado no solo situado no terço inferior (Latossolo plíntico), enquanto que o teor de C orgânico da superfície do solo também aumenta à juzante, sendo menor a sua concentração no topo e ombro e aumentando consideravelmente no terço inferior, sugerindo que há movimentação de matéria orgânica desde as posiçōes mais elevadas para os sopés.

O comportamento da areia fina entre as diferentes posiçōes topográficas variou muito pouco, sendo maior o teor no topo e ombro e diminuindo sua concentração no terço inferior, enquanto que a relaçāo $\mathrm{TI} / \mathrm{Zr}$ mostrou uma maior diferença entre estas posiçōes, sendo de menor valor no topo e aumentando em direçāo ao terço inferior, além de mostrar uma tendência à direta nas posiçōes de topo e homem à esquerda no sopé, sugerindo que podem haver diferenças de materiais de origem entre as mesmas. 


\subsubsection{Toposeqüência convexo-côncava}

As toposeqüências convexo-côncavas encontram-se situadas preferencialmente nas colinas convexo-côncavas, apresentando-se na Figura 33 o perfil característico e os solos que ocorrem em diferentes posições da mesma.

O terço superior (topo) desta toposeqüência é mais largo que o terço superior da anterior (convexa), com 1-3\% de declividade e rampa de 200-300 m, onde ocorre preferencialmente um Podzólico Vermelho-amarelo distrófico $\mathrm{Tb} \mathrm{A}$ moderado textura média/argilosa, bastante profundo $(230 \mathrm{~cm})$ e com uma camada concressionária (Cc) no contacto entre o solo e a camada Cr subjacente (perfil 30), bem drenado, porém, com algum impedimento ao fluxo vertical da água no contato solum/alterita.

No terço médio da vertente e a partir do ombro alternam-se Cambissolos álicos com diferentes espessuras. Assim, perto do ombro do PVd do topo, grada para um cambissolo álico petroplíntico Ta A moderado, textura média/argilosa menos profundo, o qual transiciona na quebra do relevo um pouco mais abaixo, para um cambissolo álico petrolítico Ta A moderado, textura média, moderadamente profundo (se considerar até a camada $\mathrm{Cr}$; perfís 31 e 32). Mais abaixo, ocorre novamente um cambissolo álico petroplíntico Ta A moderado, textura média/argilosa mais profundo (perfil 33) verificado com trado. Continuando em direção ao declive e coincidindo com afloreamentos rochosos, ocorre um cambissolo álico Ta A moderado, textura média, pouco profundo e sem a camada concressionária (perfil 34), a qual gradaciona mais abaixo para um cambissolo álico petroplíntico Ta A proeminente, textura média, moderadamente profundo e com camada concressioária em profundidade (perfil 35).

$\mathrm{Na}$ quebra do relevo entre os terços médio e inferior, ocorre um cambissolo álico Ta A moderado textura média, pouco profundo (verificado com trado). No terço inferior, o relevo muda ligeiramente, apresenta uma concavidade e os solos transicionam para um regossolo localizado no sopé. 


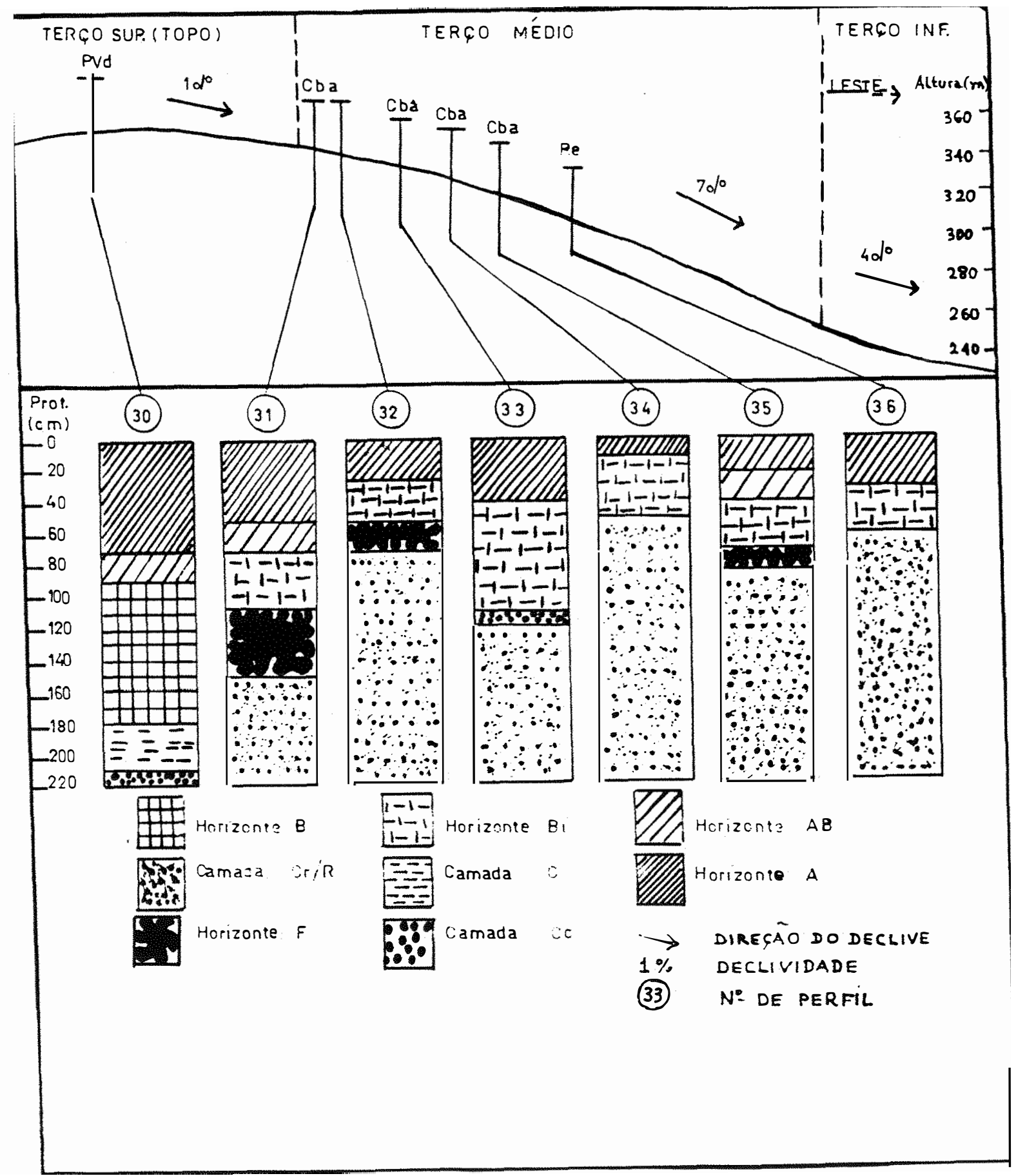

Figura 33 - Distribuição dos perfís de solos na toposeqüência convexo-côncava de "Mbokaja puku". Re = Regossolo. $\mathrm{Cb}=$ Cambissolo; $\mathrm{P}=$ Podzólico; V = vermelho-amarelo; $\mathrm{a}=$ álico; $\mathrm{d}=$ distrófico. 

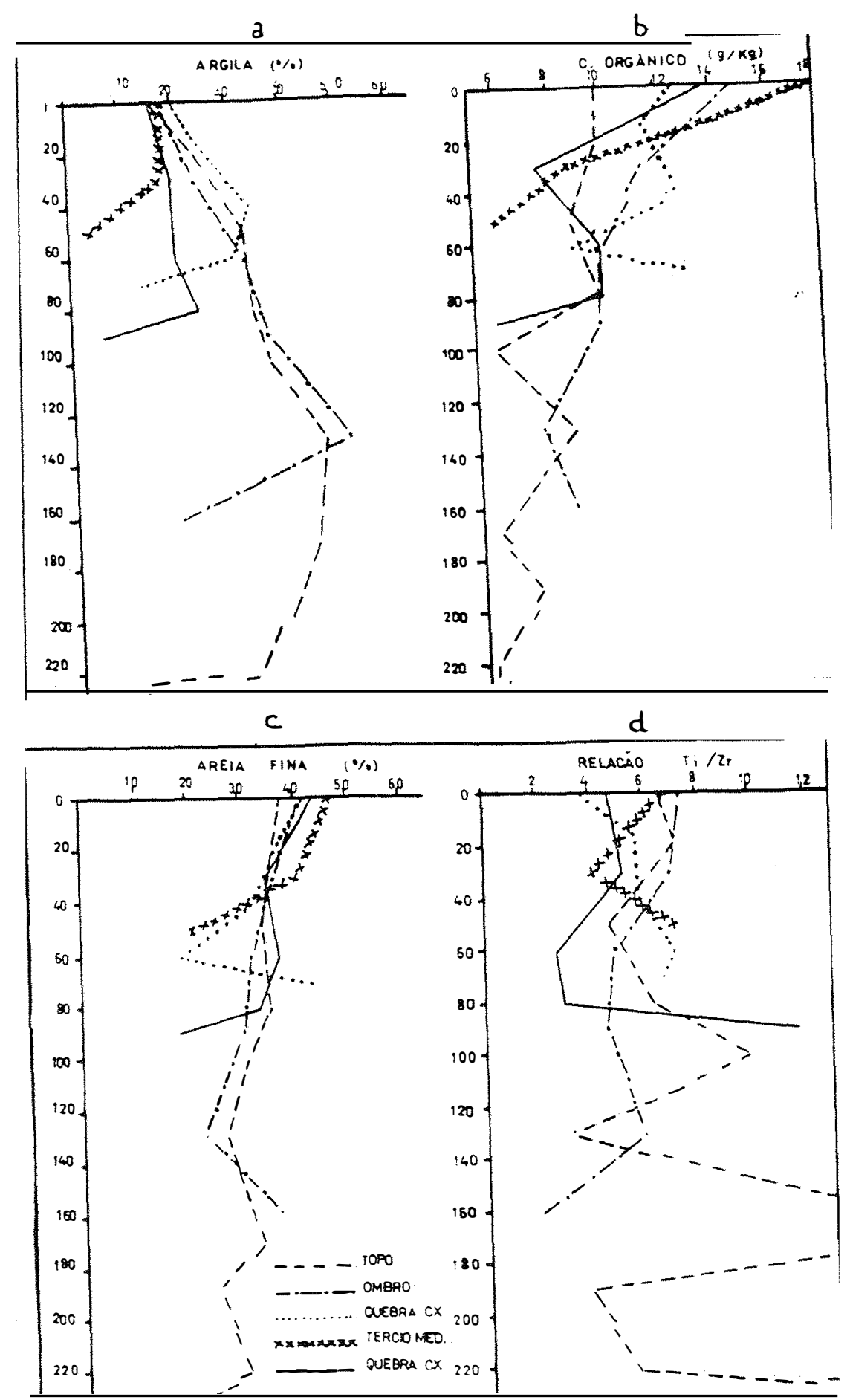

Figura 34 - Distribuição em profundidade da argila (a), do C orgânico (b). da areia fina (c) e da relação Ti/Zr (d) nos solos da toposeqüência convexo-côncava com orientação Leste e localizada em "Mbokaja puku". 
Uma diferença com as toposeqüências anteriores que é importante assinalar é que aqui o solo mais profundo ocorre no topo e o menos profundo nas quebras do relevo, para logo ficar mais espesso no terço inferior, apresentando variaçōes das camadas $\mathrm{F}$ e $\mathrm{Cr}$, em forma de degraus no terço médio principalmente com orientação leste.

As diferenças nas espessuras dos horizontes e camadas dos solos entre as diferentes posições no relevo desta vertente, indicam que a diferenciação dos mesmos foi influenciadada pela flutuação do lençol freático entre as camadas $\mathrm{Cr}$ e o solum, em nível dos degraus modelados pela teotônica, simultaneamente à vertente Oeste da colina convexa (unidade anterior).

Na Figura 34 mostra-se o comportamento em profundidade da argila, do $\mathrm{C}$ orgânico, da areia fina e da relação $\mathrm{Ti} / \mathrm{Zr}$ em cinco solos localizados em diferentes posiçōes desta toposequiência, observando-se um aumento de argila em profundidade no podzólico vermelho amarelo distrófico (perfil 30) de topo e no cambissolo álico (perfil 31) do ombro, indicando que há uma tendência de aumento de argila do horizonte $\mathrm{B}$ em direção ao topo, sendo que o teor de $\mathrm{C}$ orgânico e da areia fina do horizonte $\mathrm{A}$ tem uma tendência de aumentar em direção ao declive até a segunda quebra do relevo no cambissolo álico (perfil 34), diminuindo novamente para o cambissolo álico (perfil 35) da parte inferior do terço médio.

\subsubsection{Toposeqüência convexo-côncavo-convexa}

As toposeqüências convexo-côncavo-convexas encontram-se preferencialmente nas colinas da mesma forma superficial, ilustrando-se na Figura 35, a distribuição dos solos nas diferentes posições topográficas.

No topo destas toposeqüências, com declives de 1-3\%, ocorre um Regossolo distrófico Ta A moderado textura média, pouco profundo (50-60\%) e fortemente drenado, sendo que na encosta superior onde o declive aumenta por 25-30\%, 


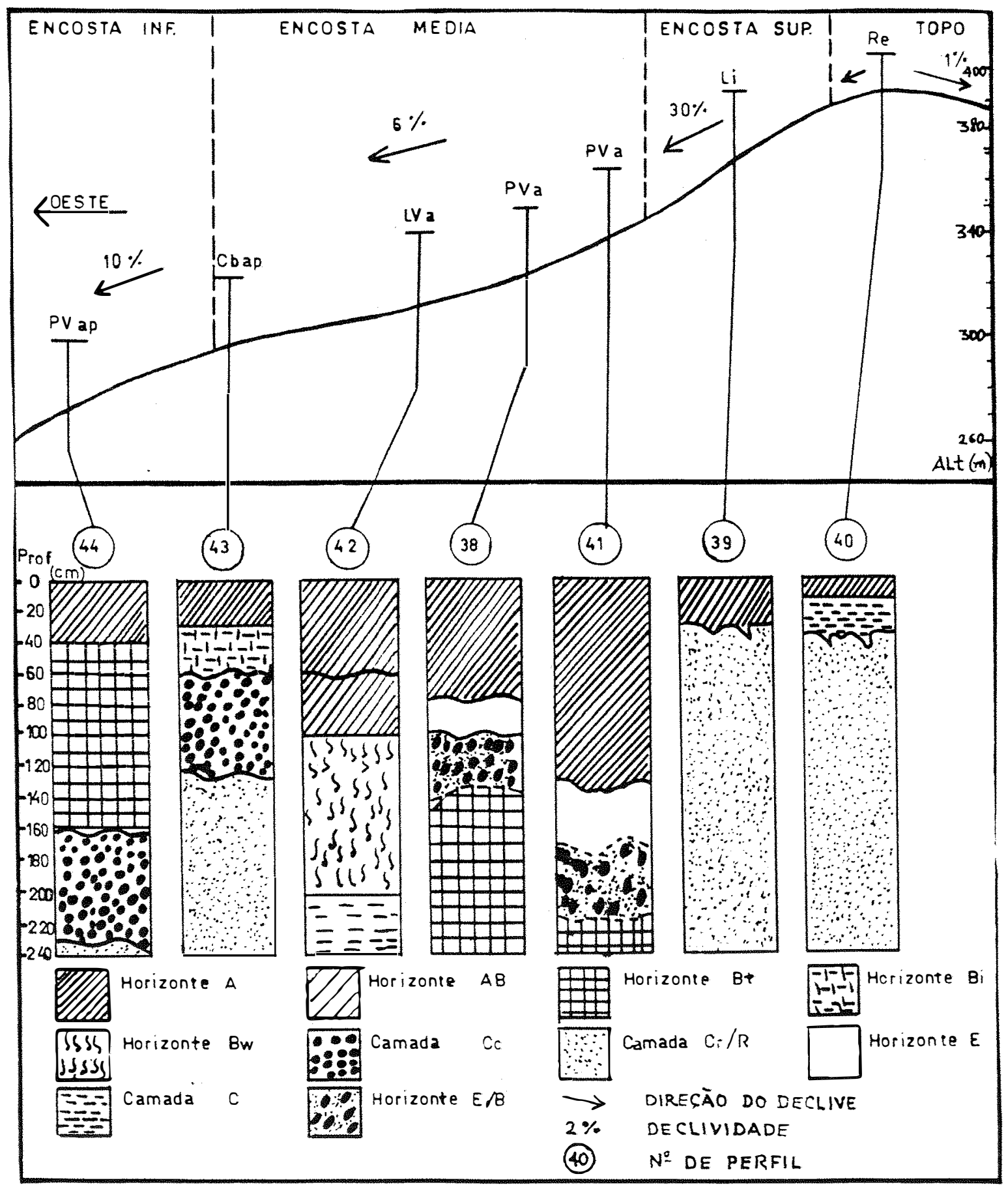

Figura 35 - Distribuição dos solos em diferentes posições da toposeqüência convexocôncavo-convexa. Re: Regossolo; SL: Solos litólicos; Cb: Cambissolo; P: Podzólico; L: Latossolo; V: vermelho-amarelo; á = álico. 
ocorre um solo Litólico distrófico Ta A proeminente, textura arenosa com forte grau de rochosidade e Pedregosidade (verificado com trado) e, na concavidade situada entre a encosta superior e a encosta média ocorre um Podzólico Vermelho-amarelo álico plíntico $\mathrm{Tb}$ A proeminente, textura arenoso-média, muito profundo ( $>2 \mathrm{~m}$ ) e bem drenado, com um horizonte E álbico sobre um horizonte plíntico pouco espesso, sendo este menos profundo na medida que a concavidade se suavisa e grada já no terço médio da encosta, onde o declive aumenta para 6-8\%, para um Latossolo Vermelho-amarelo álico A moderado textura média/argilosa, muito profundo $(2-3 \mathrm{~m})$ e bem drenado.

$\mathrm{Na}$ convexidade inferior situada entre a encosta média e a encosta inferior, onde o declive aumenta para 8-10\%, ocorre um Cambissolo álico petroplíntico $\mathrm{Tb}$ A moderado, textura média/argilosa, moderadamente profundo $(60 \mathrm{~cm})$ e com impedimento ao fluxo vertical da água devido à presença de um horizonte petroplíntico bastante espesso $(60 \mathrm{~cm})$ entre o solum e a camada $\mathrm{Cr}$, o qual passa no terço inferior (sopé) onde o declive varia de 10-12\% para um Podzólico Vermelho-amarelo álico petroplíntico $\mathrm{Tb}$ A moderado, textura média/argilosa, profundo $(140 \mathrm{~cm})$ e bem drenado, mas também com algum impedimento ao fluxo vertical da água devido à presença de um horizonte petroplíntico bastante espesso $(60 \mathrm{~cm})$ situado entre o solum e a camada $\mathrm{Cr}$.

Na Figura 36 mostra-se o comportamento em profundidade da argila, do $\mathrm{C}$ orgânico, da areia fina e da relação $\mathrm{Ti} / \mathrm{Zr}$, nas diferentes posições topográficas desta seqüência.

Pode-se observar na Figura 36a que o comportamento de argila em profundidade dos solos varia consideravelmente entre as posições do topo e da concavidade e as posiçōes situadas mas abaixo (terços médio e inferior), existindo um aumento em profundidade mais acentuado nas posiçōes inferiores (quebra convexa e terço inferior). 


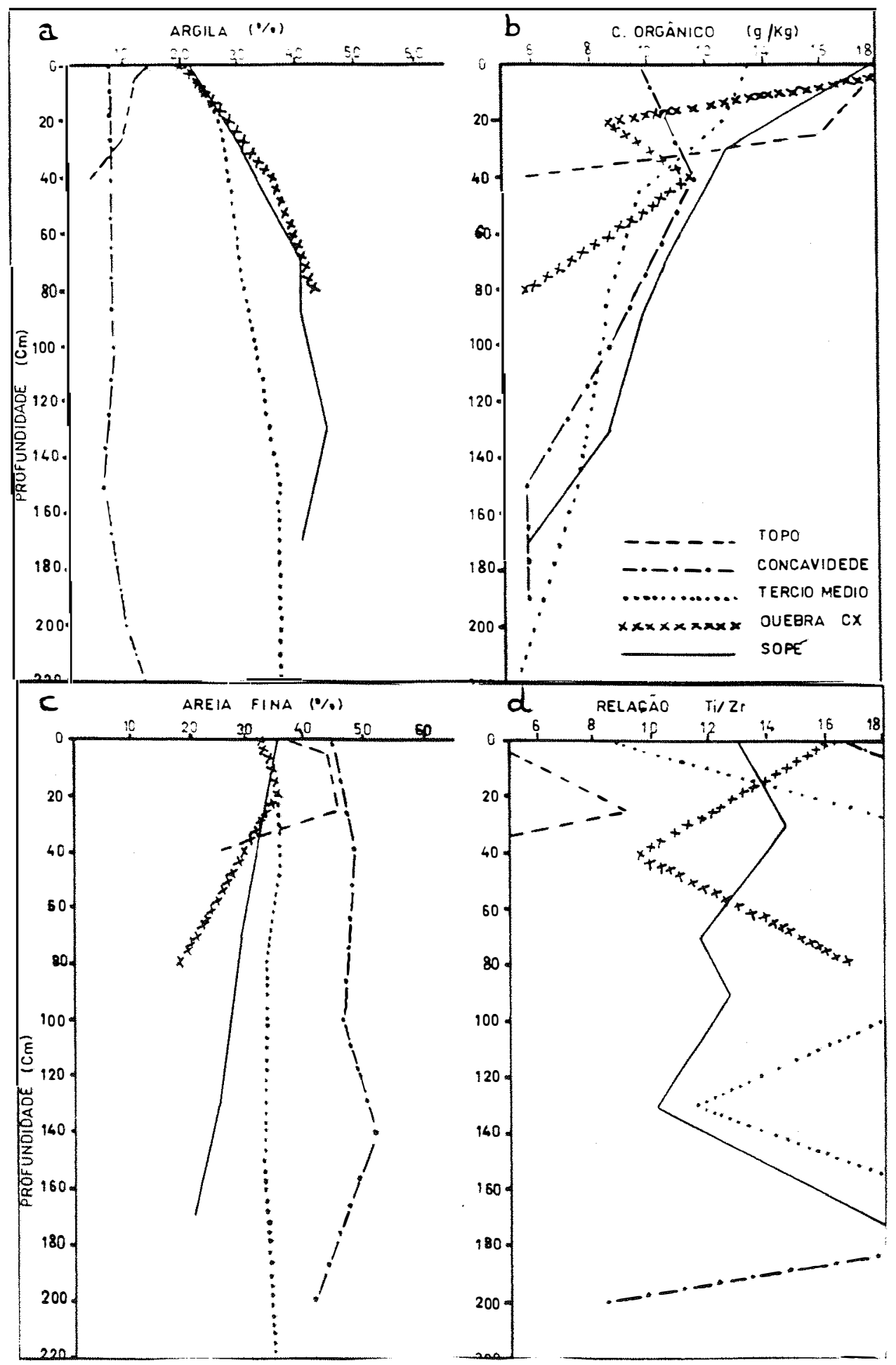

Figura 36 - Distribuição em profundidade da argila (a), do C orgânico (b), da areia fina (c) e da relação $\mathrm{Ti} / \mathrm{Zr}$ (d) nos solos da toposeqüência convexocôncavo-convexa. 
O comportamento do $\mathrm{C}$ orgânico da superfície do horizonte $\mathrm{A}$ destes solos também varia muito com relação à posição topográfica, diminuindo desde o topo em direção à concavidade, aumentando na quebra convexa e diminuindo novamente no terço inferior, sugerindo que existe transporte da matéria orgânica entre os diferentes segmentos topográficos.

A areia fina também mostra um comportamento similar ao comportamento da argila, notando-se uma pequena diferença entre as posiçōes mais elevadas da paisagem (topo, terço superior e concavidade) e as localizadas nas partes mais baixas (terço médio, quebra convexa e terço inferior).

No comportamento da relação $\mathrm{Ti} / \mathrm{Zr}$ em profundidade e nas diferentes posiçōes observa-se: primeiro que o comportamento em profundidade no solo situado no topo é muito diferente dos comportamentos nos solos situados à juzante, e segundo, que o comportamento em profundidade do solos localizados na quebra convexa não acompanha o comportamento dos outros solos (Figura 36d).

Os diferentes comportamentos observados nos solos das posiçōes topográficas sugere que pode haver diferença do material de origem entre o solo situado no topo e as demais posições.

\subsection{Relações solo-material de origem}

Muitas especulaçōes existem sobre quais materiais originaram os solos, tanto da Serra de "Cordillerita", como os que ocorrem na Serra de Altos, os quais se encontram sobre formaçōes geológicas de diferentes litologias e idades, principalmente arenitos de origem marinha (Grupos "Ca'acupé e "Itacurubi") e presença, ainda que de forma esporádica, de rochas intrusivas, assim como de possíveis aportes de sedimentos eólicos de origem vulcânica, tudo isto, sem considerar os processos de retrabalhamentos locais que tais materiais poderiam ter sofrido pela influência de processos geomórficos (erosão, movimentos de massa, neotectônica, etc). 
Muitos edafólogos e técnicos agrícolas da regiāo ainda acreditam, por exemplo, que os solos profundos e avermelhados de textura média originaram-se de materiais basálticos (de origem vulcânica), porém, alguns trabalhos desenvolvidos na Serra de Altos demonstraram que tais rochas não participaram na formação desses solos (Burgos \& Gomez, 1993).

Para entender melhor a origem e a história evolutiva dos solos da Serra de "Cordillerita", é necessário contestar as seguintes perguntas: a) quais materiais parentais originaram estes solos, ou seja, a filiação dos solos, e b) quais são os atributos do material de origem que influenciaram decididamente o caminho seguido pela pedogênese, produzindo certas características e propriedades dos solos herdadas do material de origem (Loughman, 1969).

\subsubsection{Possíveis materiais de origem}

Durante os trabalhos de campo realizados nesta pesquisa constatou-se que existe uma diferença significativa entre os atributos do solos e os do possível material de origem subjacente: diferenças de cor, textura, estrutura, agregação, consistência e limite (Figura 37). Tais diferenças levam a pensar que esses solos provavelmente não se originariam dos materiais subjacentes, porque as diferenças são tão marcadas como as apresentadas na Figura 37a, e/ou existem possíveis marcas de retrabalhamento, como algumas linhas de pedra, observadas na Figura 37b.

Pode-se observar também que o material subjacente do Podzólico Vermelho Amarelo (Figura 37a) é bem diferente do material subjacente do Latossolo Vermelho Amarelo (Figura 37b). No primeiro caso existem "entradas" em formas de línguas de material terroso (solo) dentro do possível material parental e no segundo, fraturas reliquiais com diferentes orientações e preenchimento de ferro (cores brunadas e pretas) na matriz do material rochoso. 
a

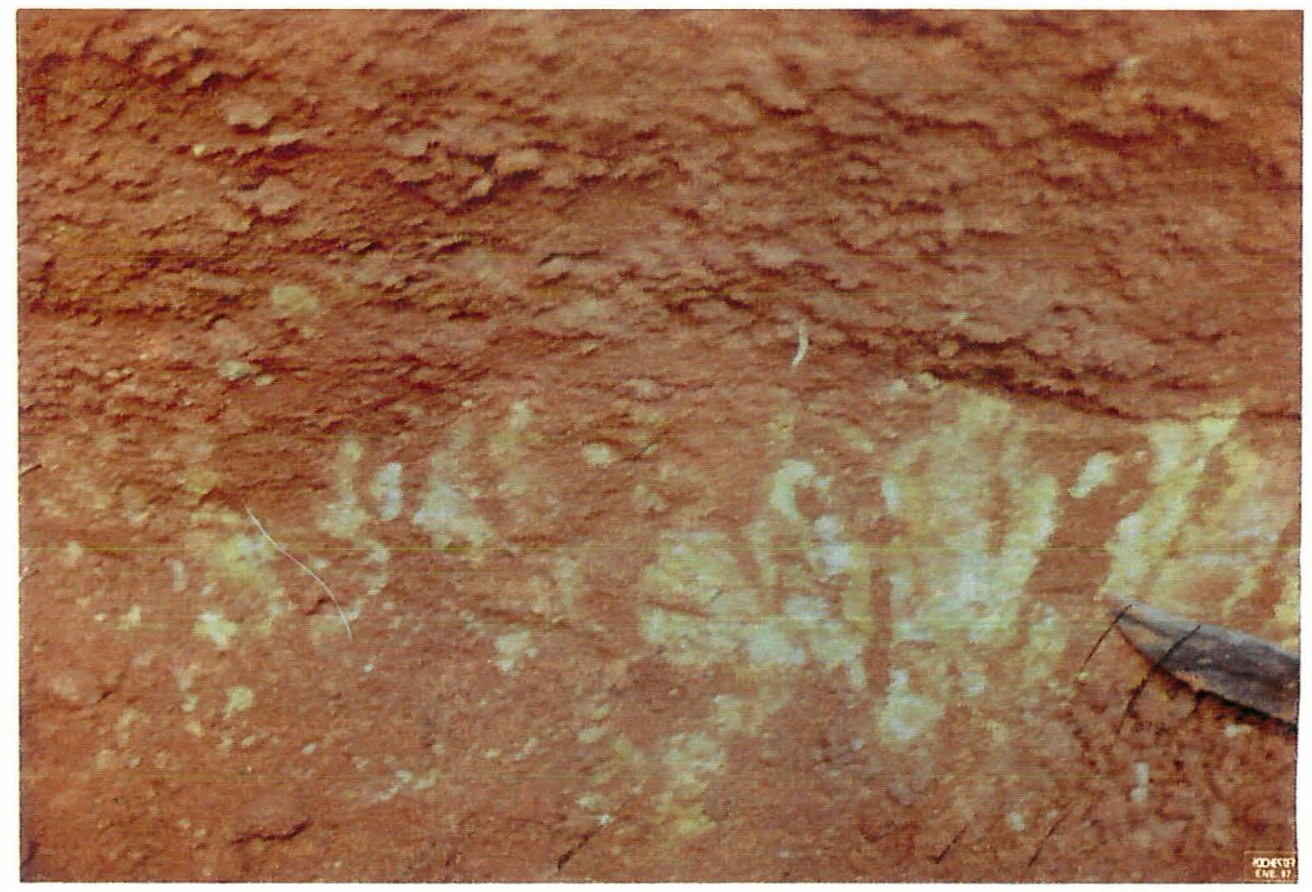

b

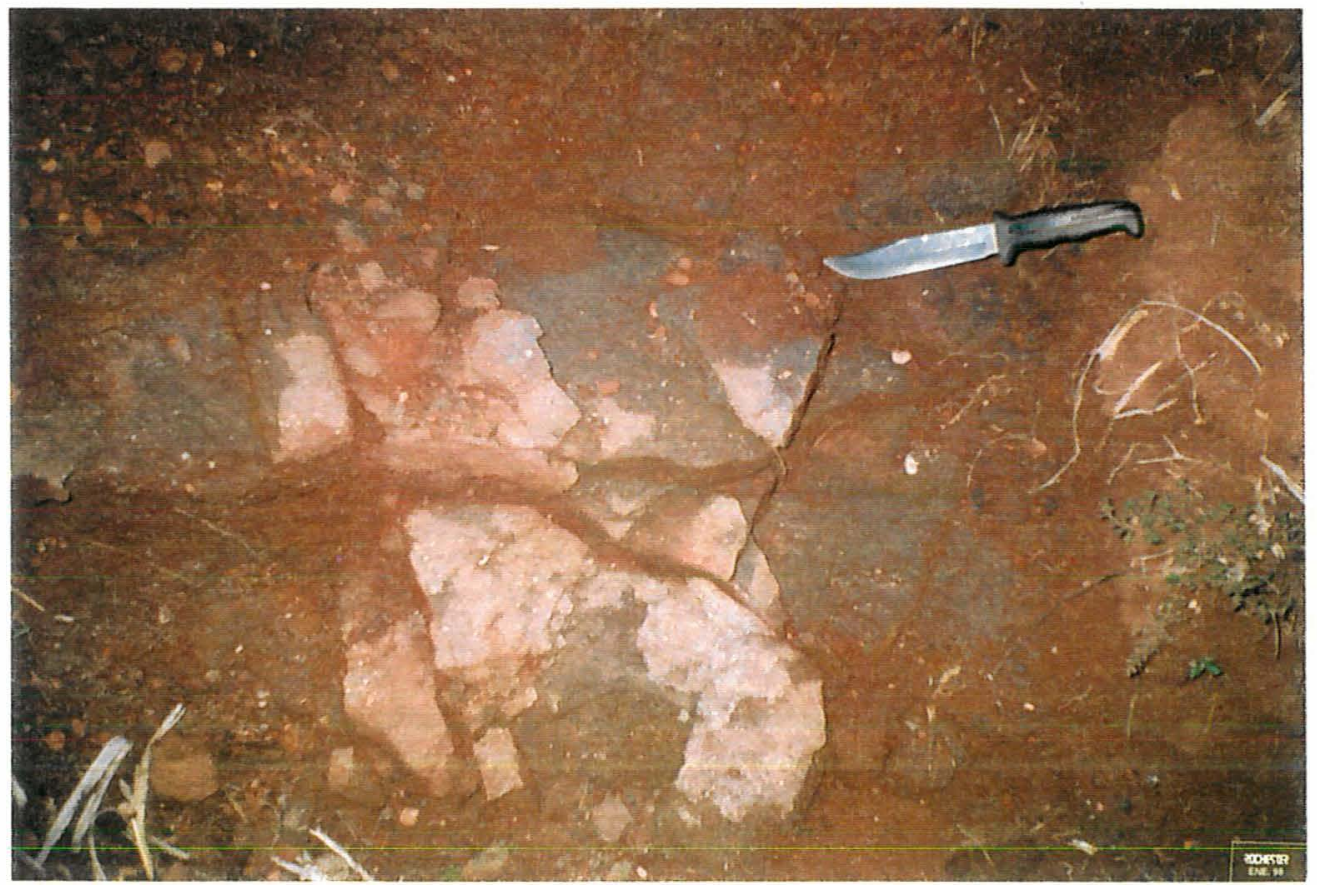

Figura 37 - Fotografias do limite solo/possível material de origem subjacente: a) Podzólico Vermelho Amarelo; b) Latossolo Vermelho amarelo. 
A produção de grande quantidade de ferro pelo intemperismo para preencher os materiais rochosos e formar os horizontes petroplínticos encontrados na maioria dos solos (principalmente Cambissolos e alguns Podzólicos) só podem ter se originado em materiais que possuem grandes quantidades de minerais cuja composição elementar esteja constituída de ferro, como por exemplo, pelas biotitas, que constituem uma boa proporção das formações do Grupo Itacurubi, e/ou de minerais ferromagnesianos que podem constituir grande proporção de rochas intrusivas básicas, assim como também de rochas de origem vulcânica (basaltos).

A possibilidade da participação das formaçōes Paraguari, Eusebio Ayala, Vargas Peña e Kari'y poderiam ficar descartadas pelos seguintes motivos: a Formação Paraguari é um conglomerado basal do grupo e não se encontrou nenhum indício deste material em nenhum solo e em nenhuma toposeqüência estudada, enquanto que o Grupo Itacurubi constituído pelas formações Eusebio Ayala, Vargas Peña e Kari'y não foram mapeadas na serra e também não foram encontradas na área de estudo durante o trabalho de campo, porém, isso não significa que num passado remoto, tais formações geológicas contribuíram desde um nível mais elevado que hoje não existe mais, e que aportaram o ferro necessário para a formaçāo das camadas petroplínticas.

A maior possibilidade de que os materiais de origem dos solos estudados sejam os arenitos "Cerro hũ" e/ou "Tobatî" pode ser deduzida da quantidade de minerais constituintes das areias finas dos mesmos, que são apresentados na Tabela 6 , ainda que tais resultados foram obtidos de lugares típicos onde tais formaçōes foram descritas originalmente e que ficam fora da área da Serra de "Cordillerita" e mais especificamente na Serra de Altos, e na Figura 38 mostra-se a distribuição do tamanho das areias das três formações do grupo "Ca'acupé" ("Paraguari, Cerro Hũ e Tobatr̂"), havendo a possibilidade de que a composição mineral das areias finas dos arenitos de "Cordillerita" sejam diferentes aos dados aqui apresentados.

Assim, as areias finas do arenito "Cerro hũ" (que perfazem uma proporção muito baixa do total das areias, < 20\%) estão constituídas por $99 \%$ de minerais leves 


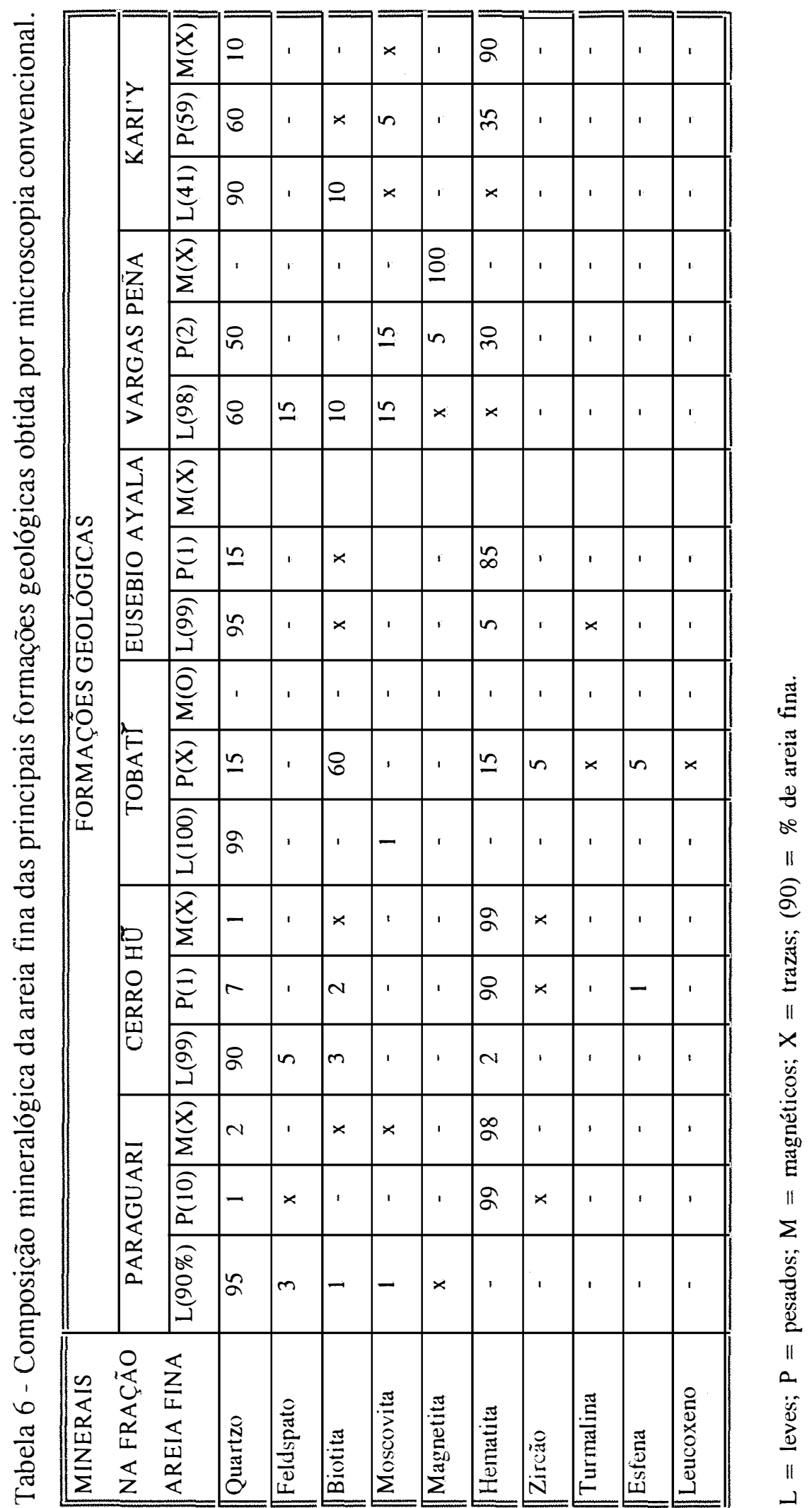




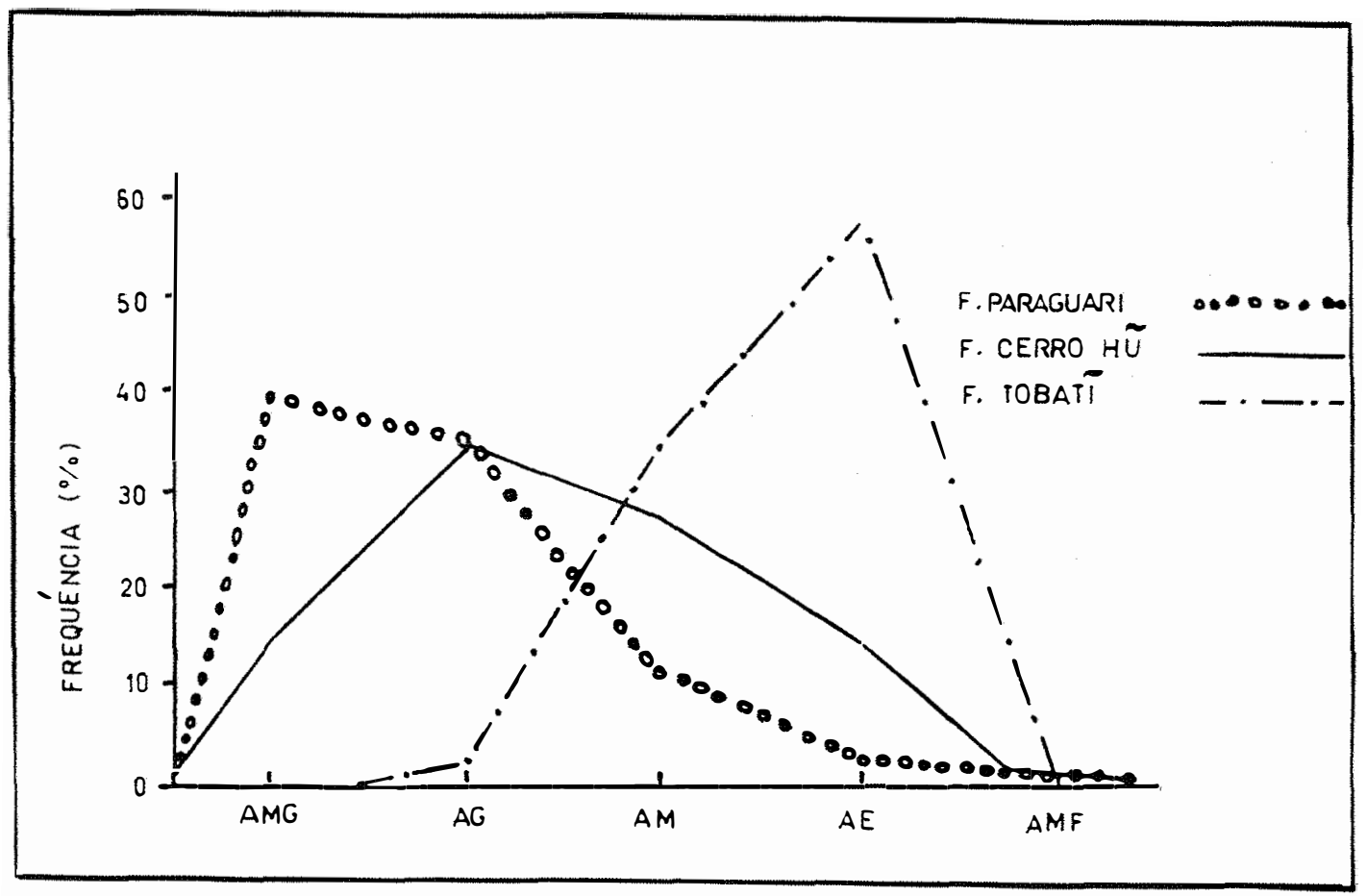

Figura 38 - Distribuição do tamanho das areias das três formações geológicas do Grupo "Ca'acupe".

(densidade $<2,45$ ), $1 \%$ de minerais pesados e traços de minerais magnéticos, dos quais, os minerais leves se constituem de $8 \%$ de feldspato e biotita, $90 \%$ de quartzo e $2 \%$ de hematita; os minerais pesados de $2 \%$ de biotita, $7 \%$ de quartzo e $90 \%$ de hematita. sendo que os minerais magnéticos são constituídos por $2 \%$ de biotita, $1 \%$ de quartzo e $99 \%$ de hematita, ou seja, pouca quantidade de areia fina contém aproximadamente $8 \%$ de minerais que poderiam originar argilas.

As areias finas do arenito sacaroidal da formação "Tobatî" (que perfazem uma alta proporção do total das areias. $55 \%$ em média) tem quase $100 \%$ de minerais leves e traços de minerais pesados, não sendo encontrados minerais magnéticos, dos 
quais, os leves estão constituídos por $1 \%$ de moscovita e $99 \%$ de quartzo; sendo que os traços de minerais pesados constituem-se por $60 \%$ de biotita, $15 \%$ de quartzo, $15 \%$ de hematita, 5\% de Zircão, 5\% de sfena e traços de turmalina e de leucoxeno.

Por outro lado, as evidências micromorfológicas encontradas apontam para o arenito arcosiano "Cerro Hũ" como principal material parental dos solos estudados. Assim, na Figura 39a, observa-se a estrutura dos grãos de areia do horizonte petroplíntico $12 \mathrm{~F}$ conservando a estrutura das areias dessa rocha, que se caracteriza por ter um gradiente granulométrico de areias grossas para areias finas em uma curta distância vertical, mais ou menos $10 \mathrm{~cm}$, como pode-se observar na Figura 40; e na Figura 39b, os grãos de areia mal selecionadas do horizọnte 13F (petroplíntico) no matriz ferruginoso, com as formas dos grãos (sub-angulares a arredondados) que conferem com as formas dos grãos dessa formação.

a

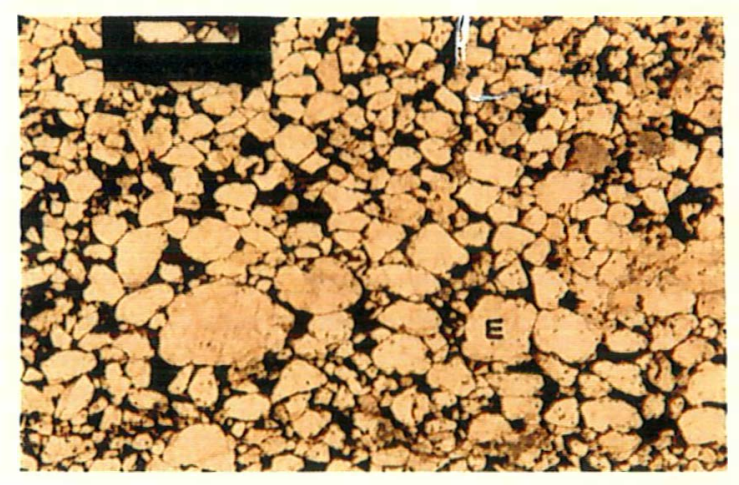

b

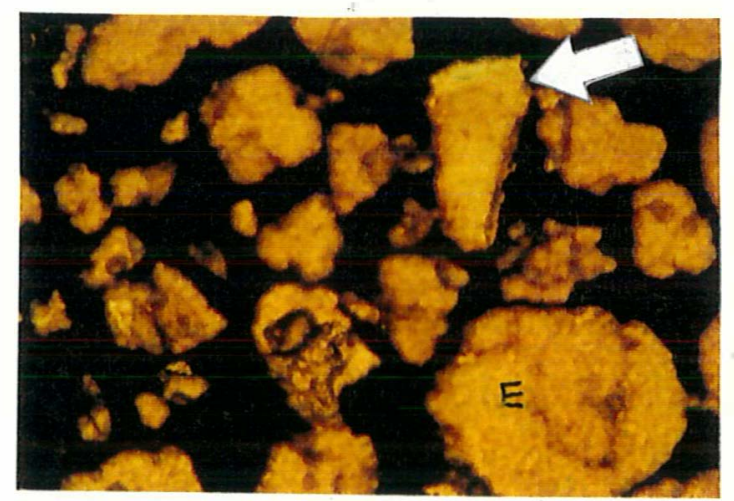

Figura 39 - Fotomicrografia das características do arenito "Cerro $\mathrm{Hu}$ ": grãos estratificados do horizonte $12 \mathrm{~F}$ (a); grãos mal selecionados e biotita no horizonte $13 \mathrm{~F}(\mathrm{~b})$. 


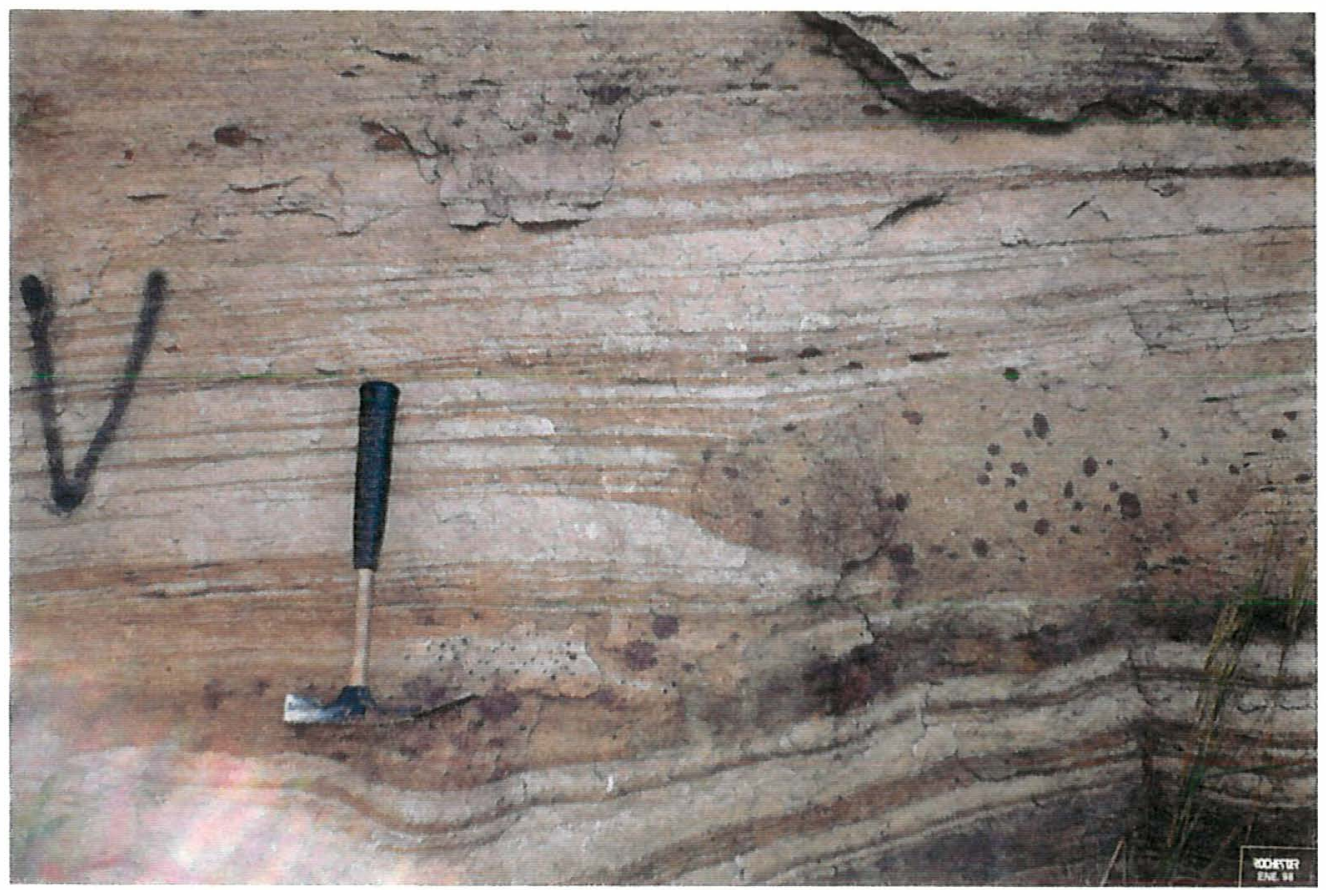

Figura 40 - Foto do arenito arcosiano (Formação "Cerro Hî̉”).

\subsubsection{Atributos dos solos herdados do material de origem}

A textura do solo é uma das características que pode ser herdada do material de origem (Birkeland, 1984). Assim, a maioria dos solos da serra tem texturas predominantemente arenosas e médias, com uma variabilidade que vai desde areia franca com $840 \mathrm{~g} / \mathrm{kg}$ de areia na camada C dos Regossolos (perfís 11 e 40) até argiloarenosa com $470 \mathrm{~g} / \mathrm{kg}$ de areia no horizonte Bt2 do Podzólico Vermelho Amarelo distrófico (perfil 30), sendo que a quantidade de argila variou desde $60 \mathrm{~g} / \mathrm{kg}$ no 
horizonte E do podzólico vermelho amarelo (perfil 41), passando para $100 \mathrm{~g} / \mathrm{kg}$ nas camadas C dos regossolos (perfís 40 e 11 ) e até $470 \mathrm{~g} / \mathrm{kg}$ no horizonte $\mathrm{Bt} 2$ do podzólico vermelho amarelo distrófico (perfil 30).

Esta variabilidade pode ter sido causada pela influência da posição topográfica na pedogênese, pela ação dos processos geomórficos como erosão e movimentos de massa lentos ("creeping“), ou devido às variações do material parental, porém contribuem para evidenciar que os materiais de origem dos solos são arenitos, e com muito maior possibilidade de que seja o arenito arcosiano da Formação "Cerro hũ ”.

Quase todos os horizontes observados em lâminas delgadas apresentaram grãos de areia com grau de seleção pobre até moderado (Tabelas 2, 7, 12 e 17), característica que só pode ser atribuída ao arenito "Cerro hũ", sendo insignificantes alguns poucos horizontes que apresentaram grãos mais bem selecionados, o que pode ser atribuído ao erro de amostragem, já que as lâminas delgadas representam muito pouca área e distância vertical, máximo de $5 \times 3 \mathrm{~cm}\left(15 \mathrm{~cm}^{2}\right)$.

A análise semiquantitativa dos minerais da fração areia fina da maioria dos solos estudados (Tabela 7), sugere que há diferenças entre os materiais de origem das diferentes colinas estudadas, assim por exemplo, há maior freqüência de feldspatos e biotita na colina convexa, com tendência a diminuir para as colinas convexo-côncavas e convexo-côncavo-convexas, o que poderia ser atribuído às próprias diferenças litológicas do arenito, porque existem diferenças de níveis entre as três colinas e/ou também porque pode ter havido diferenças do tempo de exposição ao intemperismo e de pedogênese entre as mesmas.

Outra característica que pode ter sido herdada do material de origem é o tipo de argilomineral predominante na fração argila dos solos. Assim, os principais argilominerais encontrados nos solos com diferentes graus de desenvolvimento são a caulinita, a vermiculita e a mica, podendo ocorrer alguma montmorilonita em algumas condições e solos específicos, como com drenagem imperfeita e alta concentração de cátions. 
Tabela 7 - Minerais da fração areia fina de alguns solos das três colinas estudadas.

\begin{tabular}{|c|c|c|c|c|c|c|c|c|c|c|c|c|}
\hline \multirow[b]{2}{*}{ COL. } & \multirow{2}{*}{$\begin{array}{c}\text { SOLO E } \\
\text { HOR. }\end{array}$} & \multicolumn{11}{|c|}{ MINERAIS POR CONTAGEM (\%) } \\
\hline & & & $\mathrm{Q}$ & $\mathrm{F}$ & Biot. & Musc. & Magn. & Hem. & $\mathrm{Zr}$ & Turm. & Esf. & Leuc. \\
\hline \multirow{8}{*}{$\mathrm{C}$} & \multirow[b]{2}{*}{$12 \mathrm{Bi}$} & $\mathrm{L}$ & 95 & 5 & $\mathrm{x}$ & - & - & - & - & - & - & - \\
\hline & & $\mathrm{P}$ & 60 & - & 10 & $x$ & 15 & 15 & $x$ & - & - & - \\
\hline & \multirow[b]{2}{*}{$13 \mathrm{Bw}$} & $\mathrm{L}$ & 98 & 2 & $\mathrm{x}$ & - & $\mathrm{x}$ & $\mathrm{x}$ & - & $\mathrm{x}$ & - & - \\
\hline & & $\mathrm{P}$ & 10 & - & 20 & 40 & 30 & - & - & - & - & - \\
\hline & \multirow[b]{2}{*}{$21 \mathrm{Bt}$} & $\mathrm{L}$ & 95 & 5 & - & - & - & - & - & - & - & - \\
\hline & & $\mathrm{P}$ & - & - & - & - & 50 & 50 & - & - & - & - \\
\hline & \multirow[b]{2}{*}{$22 \mathrm{Bt}$} & $\mathrm{L}$ & 95 & 5 & - & - & $x$ & - & - & - & - & - \\
\hline & & $\mathrm{P}$ & 10 & - & 10 & - & - & 80 & - & - & - & - \\
\hline \multirow{10}{*}{$\mathrm{CC}$} & \multirow[b]{2}{*}{$30 B t$} & $\mathrm{~L}$ & 95 & 5 & - & - & - & $\mathrm{x}$ & - & - & - & - \\
\hline & & $\mathrm{P}$ & 6 & 1 & 1 & 1 & $\mathrm{x}$ & 90 & 1 & - & - & - \\
\hline & \multirow[b]{2}{*}{$31 \mathrm{Bi}$} & $\mathrm{L}$ & 90 & - & $\mathrm{x}$ & - & - & 10 & - & - & - & - \\
\hline & & $\mathrm{P}$ & 2 & - & - & - & - & 98 & - & - & - & - \\
\hline & \multirow[b]{2}{*}{$32 \mathrm{Bi}$} & $\mathrm{L}$ & 98 & - & - & - & - & 2 & - & - & - & - \\
\hline & & $\mathrm{P}$ & $\mathbf{x}$ & - & - & - & 100 & - & $x$ & - & - & - \\
\hline & \multirow[b]{2}{*}{$34 \mathrm{Bi}$} & $\mathrm{L}$ & 100 & $x$ & - & - & - & - & - & - & - & - \\
\hline & & $\mathrm{P}$ & - & - & - & - & 100 & - & - & - & - & - \\
\hline & \multirow[b]{2}{*}{$35 \mathrm{Bi}$} & $\mathrm{L}$ & 100 & $\mathrm{x}$ & - & - & - & - & - & - & - & - \\
\hline & & $\mathrm{P}$ & - & - & - & - & - & 100 & - & - & - & - \\
\hline \multirow{8}{*}{$\mathrm{CCC}$} & \multirow[b]{2}{*}{$41 \mathrm{E} / \mathrm{B}$} & $\mathrm{L}$ & 100 & - & - & - & - & $x$ & - & - & - & - \\
\hline & & $\mathrm{P}$ & 10 & - & - & $x$ & - & 90 & $\mathrm{x}$ & - & - & - \\
\hline & \multirow[b]{2}{*}{$42 \mathrm{Bw}$} & $\mathrm{L}$ & 100 & $x$ & - & - & - & - & - & - & - & - \\
\hline & & $\mathrm{P}$ & 95 & - & - & - & - & 5 & $\mathrm{x}$ & - & - & - \\
\hline & \multirow[b]{2}{*}{$43 \mathrm{Bi}$} & $\mathrm{L}$ & 100 & - & - & - & - & $x$ & - & - & - & - \\
\hline & & $\mathrm{P}$ & 10 & - & - & - & - & 80 & 10 & - & $x$ & - \\
\hline & \multirow[b]{2}{*}{$44 \mathrm{Bt}$} & $L$ & 100 & $x$ & - & - & - & - & - & - & - & - \\
\hline & & $\mathrm{P}$ & 60 & - & - & - & - & 40 & - & - & - & - \\
\hline
\end{tabular}

$\mathrm{C}=$ convexa; $\mathrm{CC}=$ convexa-côncava $\quad \mathrm{CCC}=$ convexo-côncavo-convexa.

$Q=$ quartzo; $F=$ feldspato; $L=$ leves; $P=$ pesados. 
Os dados sugerem que o mineral primário precursor da formação da vermiculita foi a biotita, sendo provavelmente uma vermiculita trioctaédrica, a qual pode ter seguido a seguinte seqüência de transformação, que foi sugerida por vários autores (Dixon et al., 1989; Birkeland, 1984; Wilding et al., 1971; Birkeland, 1984; Jones et al., 1967).

Mica $===>$ Vermiculita $==>$ Esmectita (montmorilonita) (meio neutro)
\[ \|_{=}^{=}>\text {Vermiculita estratificada com hidroxi - Al (meio ácido) } \]

O mineral precursor da caulinita poderia ser principalmente o feldspato, o qual já foi alterado nas camadas $\mathrm{Cr}$ de todos os solos, ocorrendo caulinita em todas as camadas $\mathrm{Cr}$ analisadas (Figura 37a,c), a alteração direta de feldspato e de micas para caulinita foi proposta por vários autores (Pal et al., 1989; Ismail, 1969; Bryant \& Dixon, 1973, citados por Wilding et al., 1983; Tardy et al.,, 1973), enquanto que outros autores acreditam que para tal formação é necessário como produto intermediário, a formação de vermiculita em meio ácido e ambiente de desilicatização (Wilding et al., 1983).

A textura predominante e a composição mineralógica, tanto da fração areia fina como a do silte e da argila dos solos estudados, confirmam as hipóteses de que certos atributos dos solos são úteis para a identificação do verdadeiro material de origem, assim como também de que o arenito arcosiano da Formação "Cerro hũ" seja o principal material do qual se originaram tais solos, podendo existir alguns retrabalhamentos muito localizados, mas sem a participação direta de materiais que não sejam arenitos (arenitos micáceos, rochas intrusivas, basaltos, depósitos de cinzas vulcânicas, etc), porém, existe a possibilidade de que tais materiais poderiam ter contribuído indiretamente, no passado remoto, para o enriquecimento de ferro deste arenito (Figura 29b). 
Outros atributos dos solos reforçam essa hipótese como a estrutura de base e a morfometria do grão das areias obtidas através das técnicas micromorfológicas, assim a estrutura do material subjacente e a dos horizontes do solo e suas respectivas feições pedológicas, principalmente a estrutura de base das concressões de ferro (petroplintita), mostram uma estreita relação, assim como as características de arredondamento e de seleção dos grãos de areia e silte, método sugerido por vários pesquisadores (Brewer, 1976; Bullock et al., 1985).

Algumas características macromorfológicas do solo, tais como limite entre os horizontes e camadas, ainda que possam dar uma indicação sobre a possível filiação do solo, resultam insuficientes, sendo portanto necessário analisar também o comportamento em profundidade de alguns componentes químicos como a $\mathrm{Ti} / \mathrm{Zr}$ da fração areia fina, ainda que seu uso em forma isolada não seja conclusiva e devendo ser analisado conjuntamento com os dados micromorfológicos.

A presença dos horizontes petroplínticos de diferentes espessuras e morfologias na maioria dos solos estudados, sugere que outros materiais litológicos contendo em suas estruturas minerais ricos em ferro, mas hoje ausentes na serra, contribuíram diretamente com a gênese desses horizontes.

\subsection{Relações solo-relevo}

Analisando a toposeqüência mais simples, a que tem forma convexa, observou-se que alguns atributos dos solos estão relacionados às posições topográficas (Figura 29 e Tabela 8), principalmente a espessura dos horizontes, o teor da argila e a saturação por alumínio. Assim, na medida que aumentam a declividade e a distância do topo, os horizontes se tornam mais espessos, aumenta o teor de argila e diminui a saturação por alumínio.

O solo (Regossolo álico) do terço superior situado no topo e com um declive de $1 \%$ é moderadamente profundo $(70 \mathrm{~cm})$, de textura arenosa $(10 \%$ de argila) 
e com elevada saturação por alumínio (61\%), enquanto que o solo (Podzólico Vermelhoamarelo álico) situado no terço médio (a uma distância de $100 \mathrm{~m}$ do topo e com um declive de $6 \%$ ) é profundo $(170 \mathrm{~cm})$, de textura média/argilosa $(16$ e $39 \%$ de argila nos horizontes A e B, respectivamente) e continua tendo uma elevada saturação por alumínio no horizonte B (61\%) e, o solo (Podzólico Vermelho-amarelo distrófico) localizado no terço inferior (a uma distância de $500 \mathrm{~m}$ do topo e com um declive de 14\%) apresenta a maior profundidade $(200 \mathrm{~cm})$, uma textura média/argilosa $(14$ e $45 \%$ de argila nos horizontes $\mathrm{A}$ e $\mathrm{B}$, respectivamente) e uma menor saturação por alumínio (37\%).

A observação de sulcos produzidos pela erosão (Figura 29a) e das árvores inclinadas em relação à vertical, conseqüência do rastejamento, evidenciam a participação desses processos na pedogênese e na morfogênese, resultados que se assemelham aos obtidos por outros pesquisadores (Penteado, 1980; Derbyshire, 1976; Goosen, 1971; Gerrard, 1982).

$\mathrm{O}$ aumento de argila em profundidade nos solos situados no terço médio e no terço inferior (Figura 30a), suficiente para caracterizar o horizonte B textural pode ter as seguintes causas:

a) translocação vertical da argila (argiluviação);

b) diferenças na composição mineralógica no próprio material de origem; e

c) interferência de processos geomórficos.

Não se dispõem de dados para justificar que há diferenças na composição do material de origem; porém, as lâminas delgadas mostraram que houve argiluviação no passado, havendo-se observado argilãns de iluviação em poros da camada $\mathrm{Cr}$ de ambos solos, ainda que tais feições não foram observadas nas lâminas dos horizontes B, as quais mostram "stress" cutãs, sugerindo que o plasma está se reogarni-zando, processo que provavelmente tenha destruído as evidências de argiluviação no horizonte $\mathrm{B}$, devendo-se considerar também a participação dos processos geomórficos já citados para explicar o importante aumento de argila em profundidade. 


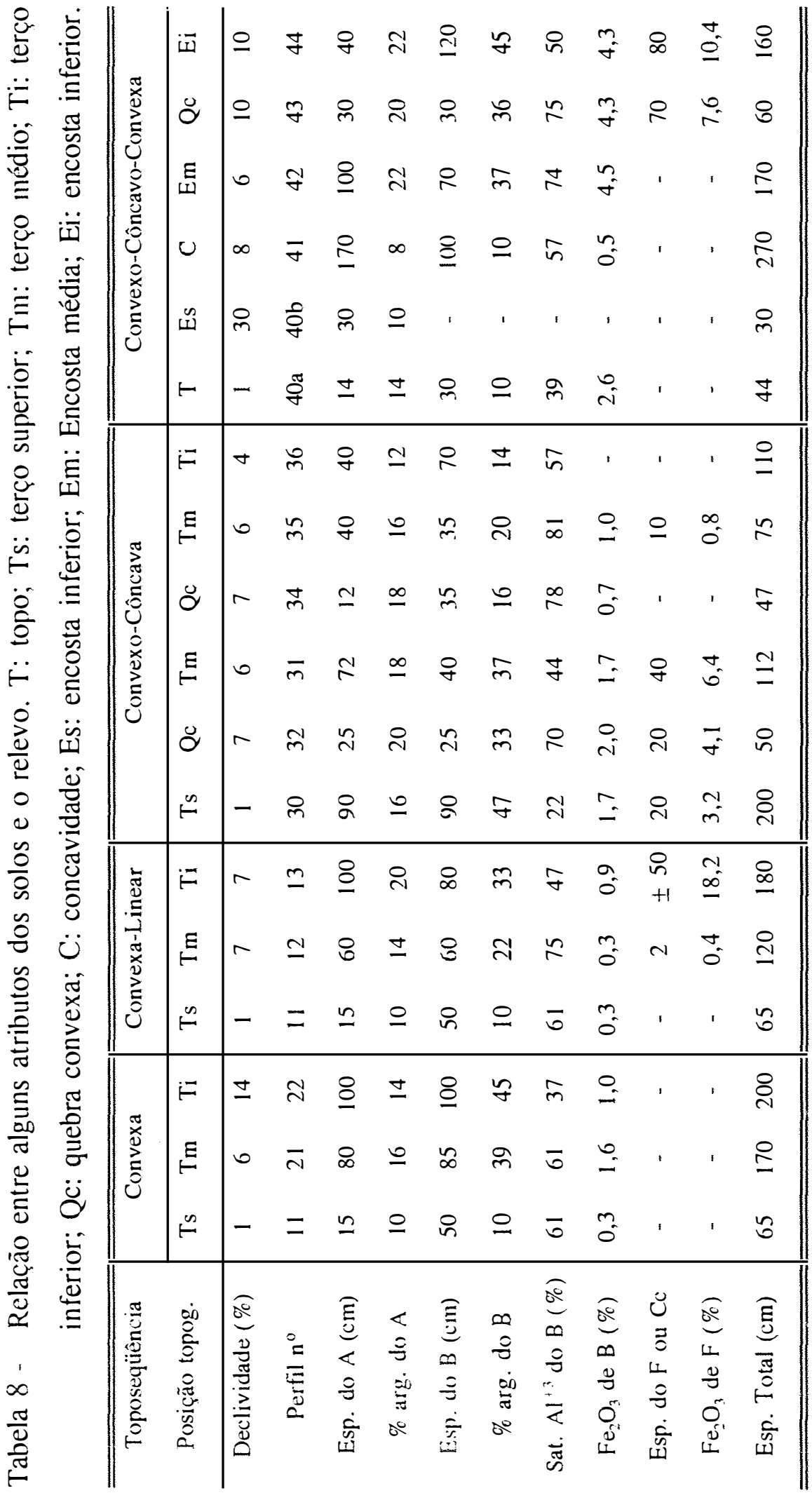


$\mathrm{Na}$ toposeqüência convexo-linear também encontrou-se uma estreita relação entre a espessura dos horizontes, o teor de argila, a saturação por alumínio e as posições topográficas, assim como também as mesmas evidências da participação de processos geomórficos na pedogênese (erosão e rastejamento), além dos quais observamse as seguintes variantes: a presença de camadas petroplínticas de diferente espessura no limite entre o solum e a camada $\mathrm{Cr}$ em toda a vertente; um perfil escalonado desta camada e cores dos solos (úmida) predominantemente bruno escuro.

No terço superior (no topo e com um declive de $1 \%$ ) ocorre um solo (Regossolo álico) moderadamente profundo $(70 \mathrm{~cm})$ de textura arenosa $(10 \%$ de argila) e com elevada saturação de alumínio (61\%), enquanto que a partir da convexidade (ombro) e no terço médio (a uma distância de $100 \mathrm{~m}$ do topo e com um declive de $7 \%$ ) ocorre um solo (Cambissolo álico) moderadamente profundo $(85 \mathrm{~cm})$ de textura média (10 a 22\% de argila nos horizontes A e B, respectivamente) e com alta saturação por alumínio $(75 \%)$, mudando para um solo profundo $(180 \mathrm{~cm})$ e fortemente desenvolvido (Cambissolo álico plíntico) que apresenta a maior diferenciação de horizonte (seqüência A- AB- Bi- Bf-F) no terço inferior (a uma distância de $300 \mathrm{~m}$ do topo e com um declive de $7 \%$ ), podendo este último ter se formado de um material de origem diferente aos solos localizados à montante, devido que o comportamento da razão $\mathrm{Ti} / \mathrm{Zr}$ deste solo mostra uma tendência a diminuir com a profundidade, comportamento diferente aos apresentados pelos solos situados à montante.

A presença de horizontes petroplínticos em profundidade nos solos desta vertente pode ter influenciado a cor dos mesmos, devido ao impedimento do fluxo vertical da água que tais horizontes podem exercer temporalmente, evidenciado pela presença de um horizonte plíntico localizado sobre o horizonte $13 \mathrm{~F}$ no solo do terço inferior.

A toposeqüência convexo-côncava mostra uma variação espacial diferente (Tabela 8), observando-se que os atributos de espessura dos horizontes, teor de argila no horizonte $\mathrm{B}$ diminuem com o aumento da declividade e da distância do topo, 
enquanto que o teor de argila do horizonte $\mathrm{A}$ e a saturação por alumínio apresentam um comportamento muito variável.

No terço superior (com um declive de 1 a $2 \%$ e uma largura maior que o topo das toseqüências anteriores) ocorre um solo (Podzólico Vermelho-amarelo distrófico) profundo $(200 \mathrm{~cm})$, de textura médio/argilosa $(16$ e $47 \%$ de argila no horizonte A e B, respectivamente) e com baixa saturação por alumínio (22\%), enquanto que no terço médio (com declives que variam de 6 a $7 \%$ e a maior distância do topo) ocorre uma sucessão de solos (Cambissolos álicos e Plintossolos pétricos álicos) moderadamente profundos $(50$ a $100 \mathrm{~cm})$ de textura média ou médio/argilosa $(16$ a $37 \%$ de argila nos horizontes A e B, respectivamente) e com diferentes saturaçōes por alumínio (44 a $78 \%$ ), e no terço inferior a partir da concavidade (com um declive de $4 \%$ e distância de $600 \mathrm{~m}$ do topo), ocorrem solos (Regossolos álicos) cuja espessura os tornam mais profundos novamente $(110 \mathrm{~cm}$ a mais), de textura média (12 a $14 \%$ de argila nos horizontes A e B, respectivamente) e alta saturação por alumínio (57\%).

Além da participação de processos geomórficos na pedogênese, observouse feiçōes de argiluviação na camada $30 \mathrm{Cr}$ do solo, localizado no terço superior (topo), enquanto que as lâminas delgadas dos horizontes B mostram "stress" cutãs que sugerem a ocorrência do processo de reorganização do plasma, o qual pode ter destruído as evidências de argiluviação neste solo.

Ao analisar a ocorrência de solos na toposeqüência convexo-côncavoconvexa, observou-se que a mesma apresenta a maior diferenciação de horizontes e de solos, acompanhando a variação das posiçōes topográficas, observando-se também uma relação entre a espessura dos horizontes, o teor de argila, a saturação por alumínio e as posiçōes topográficas, ocorrendo os solos mais desenvolvidos nas superfícies mais estáveis do relevo.

No topo (com um declive de 1 a $2 \%$ e largura de $200 \mathrm{~m}$ ) ocorre um solo (Regossolo álico) pouco profundo $(44 \mathrm{~cm})$, de textura arenosa (14\% de argila) e relativamente baixa saturaçāo por alumínio (39\%), na encosta superior (com um declive 
de $30 \%$ e 200 m de comprimento de rampa) ocorre um solo (Solos Litólicos) pouco profundo $(30 \mathrm{~cm})$, de textura arenosa (10\% de argila) e com afloramentos de rochas, enquanto que na concavidade (com um declive de $8 \%$ e comprimento menor que $50 \mathrm{~m}$ ) ocorre um solo (Podzólico Vermelho-amarelo álico) muito profundo $(270 \mathrm{~cm})$ de textura arenosa/média (8 e mais de $10 \%$ de argila nos horizontes A e $\mathrm{B}$, respectivamente), relativamente alta saturação por alumínio (57\%) e presença de um horizonte E álbico situado sobre um horizonte plíntico pouco espesso.

$\mathrm{Na}$ encosta média (com um declíve de $6 \%$ e comprimento de $500 \mathrm{~m}$ ) ocorre um solo (Latossolo Vermelho-amarelo álico) profundo $(170 \mathrm{~cm})$, de textura médio/argilosa (22 e 37\% de argila nos horizontes A e B, respectivamente) e com alta saturaçāo por alumínio (74\%). Na quebra convexa do relevo (com um declive de 10\%) ocorre um solo (Cambissolo álico) moderadamente profundo $(60 \mathrm{~cm})$ de textura médio/argilosa ( 20 e $36 \%$ de argila no horizonte A e B, respectivamente) e com alta saturação por alumínio (76\%) e, na encosta inferior (com um declive de $10 \%$ e $200 \mathrm{~m}$ de longitude) ocorre um solo (Podzólico Vermelho-amarelo álico petroplíntico) profundo $(160 \mathrm{~cm})$ de textura médio/argilosa $(22$ e $45 \%$ de argila nos horizontes A e B, respectivamente) e com uma saturação por alumínio relativamente alta (50\%).

Além da participação dos processos geomórficos (erosão, rastejamento e desmoronamento) na pedogênese, as lâminas delgadas mostraram feições de argiluviação na camada $44 \mathrm{Cr}$ e "stress" cutãs na maioria dos horizontes B destes solos, similarmente aos solos das outras toposeqüências, observando-se também a ocorrência de fluxo subsuperficial lateral da água evidenciada pela presença de um horizonte $\mathrm{E}$ álbico em transiçāo gradual para um horizonte E/B plíntico desde a concavidade até aproximadamente uns 100 metros a juzante, o qual produz, provavelmente, o processo de ferrólise (Brinkman, 1970), que também foi constatada em várias pesquisas (Brinkman, 1970; Bunting, 1961; Hamilton, 1964; Vidal Torrado \& Lepsch, 1993; Birkeland, 1984).

Nas quatro toposeqüências estudadas, verificou-se a participação dos processos geomórficos na pedogênese e na morfogênese, principalmente a erosão e o 
rastejamento, processos que se complementam para o modelado convexo do relevo (Goosen, 1971), sendo que para que o rastejamento aconteça, são requeridas algumas condiçōes, tais como a diminuição do teor de argila, da consistência em seco e da porcentagem de floculação das argilas em direção à superfície do solo, assim como uma mineralogia predominantemente caulinítica, condiçōes encontradas em todos os solos estudados (Goosen, 1971; Gerrard, 1982).

A ação do fluxo lateral da água subsuperficial e sua flutuação temporária em algumas toposeqüências, condicionadas pela presença de horizontes petroplínticos em profundidade, constituem processos importantes para a diferenciação dos atributos dos solos com relação aos segmentos topográficos, como a reorganização do plasma, o intemperismo e a transformação dos minerais primários (feldspatos e micas) em argilominerais 2:1 (vermiculitas) em meio ácido e baixa remoção do silício, alumínio e cátions do sistema, traduzidos em altos teores de alumínio e pH ácido $(4,2$ a 5,2), assim como a hidratação da hematita (goetização) concentrada nos horizontes petroplínticos, processos encontrados por vários pesquisadores (Dalrymple et al., 1968; Daniels \& Hammer, 1992; Bunting, 1961; Moniz \& Buol, 1982; Vidal Torrado \& Lepsch, 1993; Scatolini \& Moniz, 1992).

A transformação da hematita em condiçōes hidromórficas temporárias, foi evidenciada na maioria das lâminas delgadas que mostram cutãns de difusão e "stress" em posições esquelssépicas e vossépicas, processo que influi na cor do solo.

Na Figura 41 é apresentado um esquema que mostra a relação solo-relevo nas três colinas estudadas da Serra de "Cordillerita", o qual pode ser útil para o mapeamento dos solos e para o planejamento do uso da terra. 


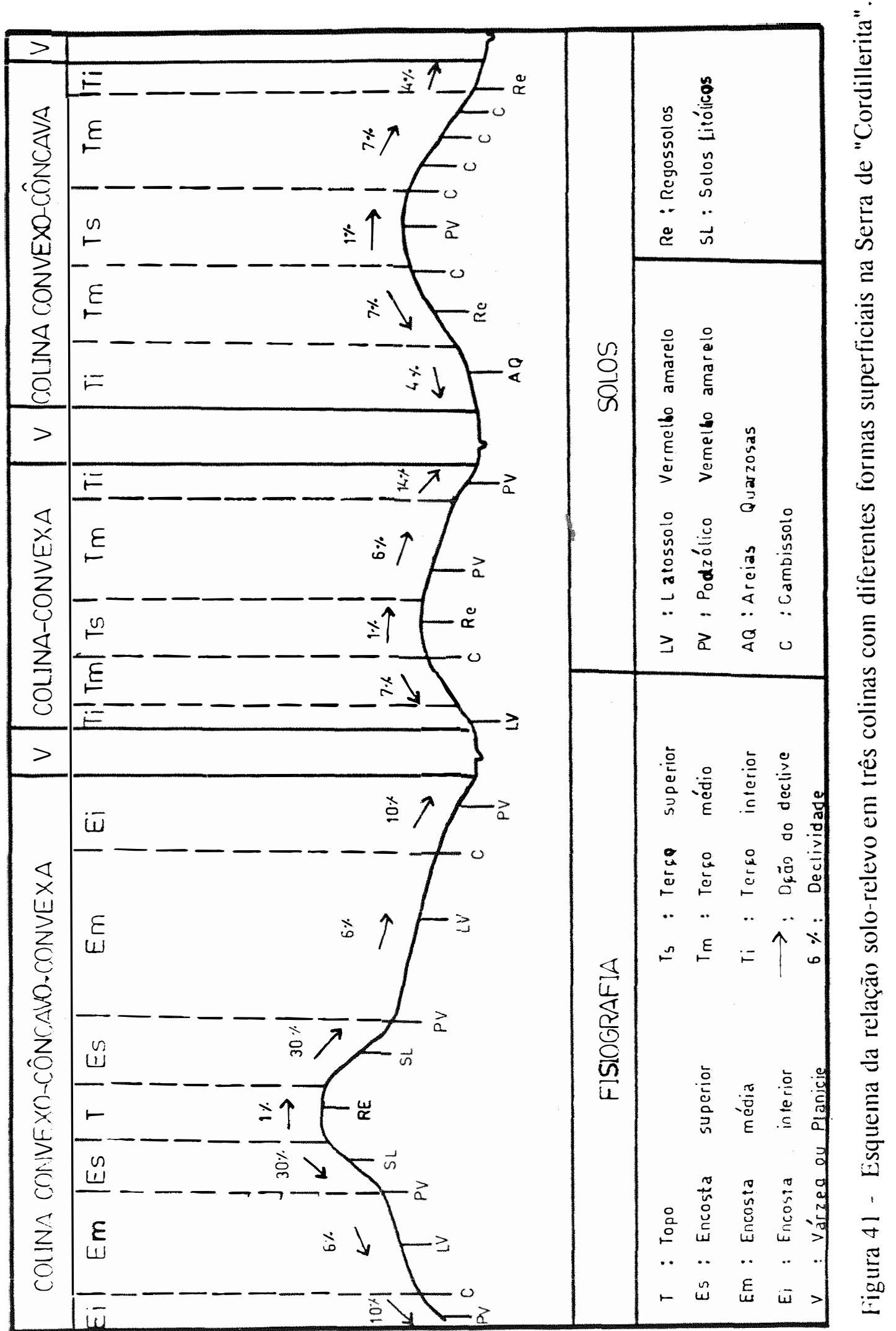




\section{CONCLUSÕES}

A mineralogia do solo constitue o principal atributo para identificar o material de origem, dado que a caulinita e a vermiculita encontradas na fração argila originaram-se a partir do feldspato e da mica, respectivamente, constituintes mineralógicos principais do material subjacente.

Outros atributos do solo, também ajudaram a identificação do material de origem, ainda que em forma secundária, tais como: a estrutura de base; a seleção e a morfometria de grãos; o comportamento em profundidade da relação $\mathrm{Ti} / \mathrm{Zr}$ e o limite entre os horizontes e camadas dos solos.

A maioria dos solos estudados são filiados ao arenito arcosiano de origem sedimentar (Formação "Cerro hu") embora não tenha sido encontrada evidência da participação direta de outras classes de rochas.

Outras rochas contendo minerais ricos em ferro em suas estruturas, mas hoje ausentes na área de estudo, contribuíram indiretamente na gênese do horizonte petroplíntico presente na maioria dos solos estudados.

O relevo da Serra de "Cordillerita" originou-se por processos tectônicos e evoluiu sob a influência de processos geomórficos (erosão, rastejamento, desmoronamento) relacionados a um clima quente e úmido, dado que as colinas encontram-se escalonadas e têm formas predominantemente convexas.

A gênese dos solos está relacionada diretamente com a posição topográfica e com a forma do relevo, encontrando-se os solos mais desenvolvidos nas posições mais estáveis da paisagem e tendo alguns atributos dos solos variado em função das formas topográficas. 


\section{REFERÊNCIAS BIBLIOGRÁFICAS}

AMERICAN COMMISSION OF STRATIGRAPHIC NOMENCLATURE. Code of stratigraphic nomenclature Bulletin of American Society of Petrology and Geology, v.45, p.645-665, 1961.

BIGARELLA, J.J.; MOUSINHO, M.R. Considerações a respeito dos terraços fluviais, rampas de colúvio e várzeas. Boletim Paranaense de Geociências, v.16-17, p. 153$197,1965$.

BIGARELLA, J.J.; MOUSINHO, M.R.; SILVA, J.X. da. Considerações a respeito das vertentes. Boletim Paranaense de Geociências, v. 16-17, p.85-116, 1965.

BILZI, A.F.; C.IOLKOSZ, E.J. A field morphology rating system to evaluate pedological development. Soil Science, v.24, p.25-48, 1977.

BIRKELAND, P.W. Correlaction of soild of stratigraphic importance in Western Nevada and California and their relative rates of profile development. In: Quaternary Soils, Univ. Nevada, Reno: University of Nevada, v.9, p.71-91, 1967.

BIKERLAND, P.W. Soils and Geomorphology. New York: Oxford University. 1984. $372 \mathrm{p}$.

BOCKHEIM, J.G. Solution and use of chronofuntions in studing soil development Geoderma, v.24, p.71-85, 1980. 
BREWER, R. Fabric and mineral analysis of soils. New York: Robert E. Krieger, 1976. 482p.

BRINKMAN, R. Ferrolysis, a hidromorphic soil forming process. Geoderma, v.3, p. 199-206, 1970.

BULLOCK, P.; FEDOROFF, N.; JONGERIUS, A.; STOOPS, G.; TURSINA, T. Handbook for soil thin section description. Waine Res. Publ., 1985. 152p.

BUNTING, B.T. The role of seepage moisture in soil development, and stream initiation. American Journal of Science, v.259, n.7, p.503-515, 1961.

BURGOS SOSA, S.M.; GOMEZ DUARTE, D. Relaciones suelo-paisaje en la Cordillera de los Altos. I. Relaciones suelo-relive. San Lorenzo, UNA/FCA/CIF (informe interno), 1993. 30p.

CAMARGO, M.N.; KLANT, E.; KAUFFMAN, J.H. Sistema brasileiro de classificação dos solos. Boletim da Sociedade Brasileira de Ciência do Solo, v. 12, n.1, p.11-33, 1987.

CAMARGO, M.N.; JACOMINE, P.K.T.; OLMOS, I.L.J.; CARVALHO, A.P. Proposição preliminar de conceituação e distinção de Podzólicos Vermelhos Escuros. EMBRAPA/SNCLS. Conceituação sumária de algumas classes de solos recém-reconhecidos nos levantamentos e estudos de correção do Serviço Nacional de levantamento e conservação do solo. Circular Técnica, n.1, p.7-20, 1982. 
CAMARGO, O.A. de; MONIZ, A.C.; JORGE, J.A.; VALADARES, J.M.S. Métodos de análise química, mineralógica e física de solos do Instituto Agronômico de Campinas. Campinas: IAC, 1986. 94p.

CHRISTIAN, C.S.; STEWART, G.A. Methodologie des études integrées. In: UNESCO: Exploration aerienne et études integrées. Paris, 1968. p.237-227.

CHURCHILL, R.R. Aspect-indiceed differences in hillslope process in Earth Surface Process and Landforms, v.7, p.171-182, 1982.

CURTIS, C.D. The description of relief in field studies of soils. In: Journal of Soil Science, v.16, n.1, p.120-130, 1965.

DALRYMPLE, J.B.; BLONG, R.J.; CONACHER, A.J. A hypothetical nine unit landsurface model. Zeitschrift für Geomorphologie, v. 12, p.60-76, 1968.

DAN, J.; YAALON, D.H. Pedomorphic forms and pedomorphic surfaces. In: INTERNATIONAL CONGRESS OF SOIL SCIENCE, 9. Adelaide, 1968. Transactions, 317-584p.

DANIELS, R.B.; HAMMER, R.D. Soil Geomorphology. New York: John Wiley, 1992. 236p.

DEMATTÉ, J.L.I. Gênese e classificação de solos originados de sedimentos do Grupo Geológico Estrada Nova. Município de Piracicaba.

DEMATTÉ, J.L.I. Zircônio e titânio da fração dos solos. Revista Brasileira de Ciência do Solo, v.2, p.74-77, 1978. 
DERBYSHIRE, E. Geomorphology and climate. London: John Wiley, 1976. 512p.

DERRUAU, M. Geomorfologia. Barcelona: Ariel, 1966. 442p.

DIJKERMAN, J.C.; CLINE, M.G.; OLSON, G.W. Properties and genesis of textural subsoil lamellae. Soil Sciente, v.104, p.7-16, 1967.

DIXON, J.B.; WEED, S.B. Minerals in soil environments. 2.ed., Madison, SSSA, 1989. 1205p.

DORRONSORO, C.; ALONSO, P. Chronosequences in Almar River Fluvial terraces. Soil Science Society of America Journal, v.58, n.3. p.910-923, 1994.

DOUGLAS, L.L. The use of soils in estimating the time of last movement of faults. Soil Science, v.129, n.6, p.345-352, 1979.

DUCHAUFOUR, P. Pedology. London: Allen \& Unwin, 1982. 428p.

ECKEL, E.B. Geology and mineral resources of Paraguay. - A reconoissance. Washington, Geol. Survey Prof. Paper no 327. MOPC/IIAA, 1959. 109p.

EMPRESA BRASILEIRA DE PESQUISA AGROPECUÁRIA. Critérios para distinção de classes de solos e de fases de unidades de mapeamento. Rio de Janeiro, EMBRAPA/SNLCS, 1988. 67p.

ESPANHA. MINISTERIO DE OBRAS PUBLICAS Y TRANSPORTES. Guía para la elaboración de estudios del medio físico: Contenido y metodologia. $3^{a}$ ed. Madrid, 1991. 572p. 
ESTADOS UNIDOS. Department of Agriculture. Soil Cons. Service. Soil Survey Staff. Soil Taxonomy: a basic system of soil classifications for making and interpreting soil surveys. Washington, DC, 1975. 754p. (USDA. Agriculture Handbook, 436).

FAIRBRIGDE, R.W. The encyclopedia of geomorfology. New York: Reinold Book, 1968. 1295p.

FILIZOLA, H.F.; BOULET, R. Evoluation et coverture des depressions fermees sur substrat quartzo-kaolinitique dans le Bassin de Taubaté, São Paulo, Brasil. In: CONGRESSO INTERNACIONAL DE GEOMORFOLOGIA, 30., Hamilton, 1993. Transactions. $312-321 \mathrm{p}$.

FINNEY, H.R., HOLOWAYCHUK, N.; HEDLESON, M.R. The influence of microclimate on the morphology of certain soils of the Allegheny Plateau of Ohio. Proceedings of the Soil Science Society of America, v.26, p.287-292, 1962.

FRIDLAND, V.M. The structure of Soil cover. Soviet Soil Science, v.4, p.343-355, 1965.

GERRARD, A.J. Slope form and regolith characteristics in the Basin of the of the River Cowsic, Central Dartmoor, Devon. London. 1982. 185p. Thesis (Doctor) University of London.

GERRARD, J. Soil geomorphology an integration of pedology and geomorphology. London: Chapman \& Hall. 1995. 268p.

GIBBONS, F.R.; DOWNES, R.G. A study of the land in South Western Victoria. Soil Cons Auth. Melbourne: Soil Conservation Authority, 1964. 289p. 
GILE, L.H.; PETERSON, F.F.; GROSSMAN, R.B. Morphological and genetic sequences of carbonate accumulation in desert soils. Soil Science, v.101, p. 347-360, 1966.

GODFREY, A.E. A physiographic approach to land use planing. Enviromental Geology, v.2, p.120-127, 1977.

GOLDICH, S.S. A study in rock weathering. Journal of Geology, v.46, p.17-58, 1938.

GONZALEZ, M.E.; BARTEL, W.; LAHNER, L.; MUFF, R.; WIENS, F. Mapa geológico de la Republica del Paraguay Hoja San Jose. Asunción. Ministério de Obras Públicas u Comunicaciones, 1996 (Escala 1:100.000).

GOOSEN, D. A study of geomorphology and soils in the middle Magdalena Valley, Colombia. Delft.: ITC, 1961. 39p.

GOOSEN, D. Interpretación de fotos aéreas y su importáncia en levantamientos de suelos. Roma: FAO, 1968. 58p. (Boletim, 6).

GOOSEN, D. Physiography and soils of the Llanos Orientales. Colombia Amsterdam, 1971. 198p. Thesis (Doctor) - University of Amsterdan.

HACK, J.T. Interpratation of erosional topography in umid temperate regions. American Journal of Science, v.258, n.1, p.80-97, 1960.

HAMILTON, R. Microscopic studies on laterite formation. In: Soil micromorphology. New York: Elsevier Publ., 1964. p.269-276. 
HARDEN, J.W. A quantitative index of soil development form field descriptions: example from a chronosequence in Central California. Geoderma, v.28, n.1, p. 1-28, 1982.

HARDEN, J.W.; TAYLOR, E.M. A quantitative comparation in soil development in four climatic regimes. Quaternary Research, v.20, p.342-359, 1981.

HASSEMAN, J.F.; MARSHALL, C.E. The use of heavy minerals in studies of the origin and development of soils. Montana: Agriculture Experimentation Station. 175p. 1945. (Bulletin, 387).

HASUI, Y. Neotectônica e aspectos fundamentais da tectônica ressurgente no Brasil. Boletim da Sociedade Brasileira de Geologia, Núcleo Minas Gerais, v.11, p.1-31, 1990.

HOLDRIDGE, L.R. Estudio ecológico de los bosques de la Región Oriental del paraguay. Asunción, FAO-SF. Doc. de trab. n 1, 1969. 19p.

HOLE, F.D. Suggested terminology for describing soils at three dimentional bodies. Soil Science Society of America Proceedings, v.17, p.131-135, 1953.

HOLMES, C. Geomorphic development in humid and arid regions: a synthesis. American Journal of Science, v.253, 1955.

HUECK, K.; SEIBERT, P. Mapa de la vegetación de América del Sur. Eschborn: GTZ, 1988. 16p. 
ISMAIL, F.T. Role of ferrous iron oxidation in the alteration of biotite and its effect on the type of clay minerals formed in soils of arid and humid regions. American Mineralogy, v.54, p.1460-1466, 1969.

INSTITUTO INTERNACIONAL PARA EL DESARROLLO Y MEDIO AMBIENTE. Perfil ambiental del Paraguay. Asunción: Ed. Cromos, 1985. 173p.

JACKSON, M.L.; SHERMAN, G.D. Chemical weathering of minerals in soils. Advanced Agronomy, v.5, p.219-318, 1953.

JACKSON, M.L.; TYLER, B.A.; WILLIS, A.L.; BOURBEUA, G.A.; PENGVINTON, R.P. Wheathering sequence of clay-size minerals in soils and sendiments. I. Fundamental Generalization. Journal of Phisic and Cell Chemistry, v.52, p.1237-1260, 1948.

JACKSON, M.L. Soil chemical analysis. Advanced Course, 2.ed., Madison, SSSA, 1969. $991 \mathrm{p}$.

JENNY, H.E.W. Factors of soil formations. McGraw Hill, New York, 1941.

JENNY, H.E.W. Hildgard and the birth of modern soil science. Pisa: Farallon Publ., 1961. s.p.

JOHNSON, W.M. The pedon and polipedon. Soil Science Society of America Proceedings, v.27, p.212.215, 1963.

JONES, L.H.P.; MILNE, A.A.; ATTIWILL, P.M. Diortahedrol vermiculite and chlorite in highly weathered red loams in Victoria, Australia. Soil Science Society of American Proceedings, v.28, n.1, p.108-118, 1964. 
KING, L.C. Canons of landscape evolution. Bulletin of Geology of the Society of America, v.64, p.721-751, 1953.

LEMOS, R.C.; SANTOS, R.D. dos. Manual de descrição e coleta de solo no campo. Campinas: SBCS/SNLCS, 1984 . p.45.

LEPSCH, I.F. Soil-landscape relationships in an area of the Occidental plateau of São Paulo, Brazil. Raleigh, 1975. 163p. Thesys (Ph.D) - North Caroline State University.

LOPEZ, O.; GONZALEZ, E.; LLAMAS, P.A. de; MOLINAS, A.S.; FRANCO, E.S.; GARCIA, S.; RIOS, E.O. Mapa de reconocimiento de suelos de la Región Oriental, Paraguay. Asunción: Proyecto de racionalización del uso de la tierra, 1995. (Escala 1:500.000).

LOUGHMAN, F.C. Chemical weathering of the silicate minerals. New York: Elsevier, 1969. 154p.

LOSCHE, C.K.; McCRACKEN, R.J.; DAVEY, C.B. Soils of steeply sloping landscape in the Southern Apalochian Mountains. Proceedings of the Soil Science Society of America, v.34, p.473-478, 1970.

MARQUES JUNIOR, J. Distribuição e atributos dos solos em relação à forma e evolução de uma vertente em Monte Alto, SP. Piracicaba, 1995. 226p. Tese (Doutorado) - Escola Superior de Agricultura "Luiz de Queiroz", Universidade de São Paulo.

McFARLANE, M.J. Laterite and landscape. London: Academic Press, 1976. $151 \mathrm{p}$. 
MENDES, J.C. Aspectos da estratigrafia do Quaternário In: QUEIROZ, T.A. Elementos de Estratigrafia. São Paulo: EDUSP, 1984. 488-496pp.

MILANKOVITCH, M. Kanon der Erdestrahlung und Seine Awendung aref das Eiszeiten problem. Belgrado: Academy Royal, vol. 13, 331p. 1941.

MILNE, G. Some suggested units of classification and mapping particularly for East African soils. Soil Research, v.4, n.3, p.183-198, 1935.

MILNE, G. Normal erosion as a factor in soil profile development. Nature, v.138, p.548-549, 1936.

MILLOT, G. Planation of continents by intertropical weathiring and pedogenic process. In: INTERNATIONAL SEMINAR ON LATERIZATION PROCESS, 2., São Paulo, 1982. Proceedings. 53-63p.

MONIZ, A.C.; BUOL, S.W. Formation of on Oxisol ultisol transition in São Paulo, Brazil: I. Double water flow model of soil development. Soil Science Society of America Journal, v.46, p.1228-1233, 1982.

MOURA, J.R.S. de. Geomorfologia do Quaternário. In: GUERRA, T.; CUNHA, S.B. da. Geomorfologia: uma atualização de bases e conceitos. Rio de Janeiro: Ed. C.I., 1994. 458 p.

MUIR, J.W. The general principles of classification with reference to soils. Journal of Soil Science, v.13, p.22-30, 1962. 
NETTLETON, W.D.; FLACH, K.W.; BRASHER, B.R. Argillic horizons without clay skins. Soil Science Society of America Proceedings, v.33, p.121.125, 1969.

OliveirA, J.B. de; JACOMINE, P.K.T.; CAMARGO, M.N. Classes gerais de solos do Brasil: Guia auxiliar para seu reconhecimento. Jaboticabal: FUNEP, 1992. $201 \mathrm{p}$.

OLLIER, C.D. A two-cycle theory of tropical pedology. Journal of Soil Science, v.10, p.137-148, 1959.

PAL, D.K.; DESHPANDE, S.B.; VENUGOPAL, K.R.; KALBANDE, A.R. Formation of Di- and Triortahedral Smectite as evidence for paleoclimatic changes in Southern and Central Peninsular India. Geoderma, v.45, p.175-184, 1989.

PARAGUAI. Mapa Geologico del Paraguay. Asunción: Ministério de Defensa Nacional, 1986. (Escala 1:1.000.000).

PARSONS, R.B. Soil Geomorphology relations in moutains of Oregon, USA. Geoderma, v.21, p.25-39, 1978.

PELLERIN, J,; QUEIROZ NETO, J.P. Morfogênese e pedogênese no córrego da invernada, Marília, SP. In: CONGRESSO DA ASSOCIAÇÃO BRASILEIRA DO QUARTENÁRIO, 2., Belo Horizonte. Anais, p.111-120. 1992.

PENCK, A. Die Gipfelflur der Alpen. Berlin. p.256-258. 1919.

PENCK, W. Morphological analysis of landforms. London: McMillan \& Co., 429p. 1953. 
PENTEADO, M. Fundamentos de geomorfologia. Rio de Janeiro: IBGE, 1980. $185 \mathrm{p}$.

RUHE, R.V.; DANIELS, R.B.; CADY, J.G. Landscape evolution and soil formation in South Western Iowa USDA. Washington: Technical Bulletin $\mathrm{n}^{0}$ 1349. 1967.

SCATOLINI, F.M.; MONIZ, A.C. Influência do material de origem, do lençol freático surgente e da posição topográfica nos solos de uma encosta em Mococa (SP). Revista Brasileira de Ciência do Solo, c.16, n.3, p.379-388, 1992.

SCHWERTMANN, V.; TAYLOR, R.M. Iron oxisol. In: DIXON, J.B.; WEED, S.B. (ed.). Mineral in soil environments. Madison: SSSA, 1977. p.145-180.

SHAW, C.F. Profile development and relationship of soils in California. In: CONGRESS OF SOIL SCIENCE PROCEEDINGS, V.4, P.291-397, 1928.

SHAW, C.F. Potent factors in soil formation. Ecology, v.2, p.239-245, 1930.

SOIL SURVEY STAFF. Keys to Soil Taxonomy. 6.ed., Washington: USDA/SCS, 1994. 306p.

STRAHLER, A.N. Statistical analysis in geomorphic research. Journal of Geology, v.62, p. $1-25,1954$.

STOLT, M.H.; BAKER, J.C.; SIMPSON, T.W. Soil landscape relationships in Virginia. I. Soil variability and parent rock uniformity. Soil Science Society of America Procedings, v.57, n.2, p.441-481, 1993. 
TARDY, Y.; BOCQUIER, G.; PAQUET, H.; MILLOT, G. Formation of clay from granite and its distribution in relation to climate and topography. Geoderma, v.10, p.271-284, 1973.

THE ANCHUTZ CORPORATION. Mapa Geológico de la Región Oriental del Paraguay. (Mapa en escala 1:500.000), 1981.

TONKIN, P.J.; BASHER, L.R. Soil stratigraphic techniques in the study of soil and landform evolution across the Southern Alp., New Zeland. Geomorphology, v.3, p.547-575, 1990.

TORRENT, J.; NETTLETON, W.D. Feedback process in soil genesis. Geoderma, v.20, p.281-287, 1978.

TRICART, J. As relações entre a morfogênese e a pedogênese. Notícia Geomorfológica, v.8, n.15, p.5-18, 1968.

VAN DIJK, D.C. Soil features in relation to erosional history in the vicinity of Camberra. Australian CSIRO Soil Publication, v.13, p.1-41, 1959.

VAN WANBEKE, A. Soils bodies and soil calssification. Soil Fertilization, v.29, p.507-516, 1966.

VIDAL TORRADO, P.; LEPSCH, I.F. Morfogênese dos solos de uma toposeqüência com transição B latossólico x B textural sobre migmatitos em Mococa (SP). Revista Brasileira de Ciência do Solo, v.17, n.1, p. 109-119, 1993. 
VREKEN, W.J. Principles Kinds of chronosequences and their significance in soil history. Journal of Soil Science, v.26, p.378-398, 1975.

WALKELEY, A.; BLACK, J.A. An examination of the Degtjareff method for determining soil organic matter, and proposed modification of the chronic acid tetration method. Soil Science, v.37, p.29-38, 1934.

WILDING, L.P.; SMECK, N.E.; HALL, G.F. Pedogenisis and Soil Taxonomy. I. Concepts and interactions Elseiver Amsterdam 303p. 1983.

WILDING, L.P.; DRESS, L.R.; SMECK, N.E.; HALL, G.F. Mineral and elemental composition of Wisconsin till deposits in West Central Ohio. In: Till: A symposium. Columbia: Ohio State University Press, 1971. p.299-318.

YAALON, D.H. Conceptual models in pedogenisis: can soil forming factors be solved? Geoderma, v.14, p.189-205, 1975. 
142

APÊNDICE 


\section{A. DESCRIČ̃̃O GERAL}

PERFIL: $\mathrm{N}^{0} 11$

CLASSIFICACÃO: Regossolo álico Ta A moderado textura arenosa, fase floresta subtropical subperennifolia substrato arenito, relevo ondulado.

LOCALIZACÃ̃O: Fundo da propriedade do Austríaco e $20 \mathrm{~m}$ ao leste do capão da parte alta.

COORD. UTM: E0513600/N7131750 UN. PEDOGEOMÓRFICA: 1a

RELEVO LOCAL: ondulado

ALTITUDE: 375 m.s.n.m.

RELEVO REGIONAL: ondulado e forte ondulado

DECLIVE: $1 \%$

DIREÇÃO: S

POSIČÃO TOP: topo

COMPRIMENTO: $50 \mathrm{~m}$

FORMACÃO GEOL.: "Tovatî"

LITOLOGIA: Arenito sacaroidal

MAT.PARENTAL: saprólito de arenito.

ROCHOSIDADE: não rochosa

PROF. DO LENCOL: $>2 \mathrm{~m}$

INUNDACÕES: nula

EROSÃO: laminar moderado

PEDREGOSIDADE: não pedregosa

DRENAGEM: acentuadamente drenado

VEGET. PRIMÁRIA: Floresta subtropical subperennifolia

USO ATUAL: pastoreio

PRODUTIVIDADE: baixa

CLIMA: temperado chuvoso ( $\mathrm{Cfa}$ )

DESCRITO POR: Sérgio M. Burgos

\section{B. DESCRIĊ̃̃O MORFOLÓGICA}

A $\quad 0-15 \mathrm{~cm}$, bruno escuro (7.5 YR 3/3, úmido), bruno (7.5 YR 5/3, seco); areia franca; fraca média a grande granular e fraca pequena blocos subangulares; macio, friável, não plástico e não pegajoso; transição gradual e ondulada.

C 15-50/70 cm; bruno escuro (7.5 YR 3/4, úmido), bruno (7.5 YR 5/3, seco); areia franca; fraca média a grande blocos subangulares; macio, friável, não plástico e não pegajoso; transição abrupta e irregular.

Cr1 50-60cm, bruno escuro (7.5 YR 4/3, úmido), bruno claro (75 YR 6/3, seco); areia; maciço; muito duro, friável, não plástico e não pegajoso; transição clara e plana.

Cr2 60-70 cm; bruno clara acinzentada (10 YR 6/3, úmido), branco (10 YR 8/2, seco); areia franca; maciço; muito duro, friável, não plástico e não pegajoso.

RAÍZES: poucas e finas no A, poucas e muito finas no $\mathrm{C}$, raras e muito finas no $\mathrm{Cr} 1$.

OBSERVAÇÕES: cascalho em todo o perfil em forma de concresões, poucas, pequenas, duras, irregulares de cor bruno escuro e calhau em forma de fragmentos de arenito e concresões similares aos anteriores. 
ATRIBUTOS FÍSICOS DO PERFIL N ${ }^{\circ} 11$

\begin{tabular}{|c|c|c|c|c|c|c|c|c|c|c|c|c|c|c|c|c|}
\hline \multirow{2}{*}{\multicolumn{2}{|c|}{$\begin{array}{l}\text { Horizontes } \\
\text { e/ou camadas }\end{array}$}} & \multicolumn{4}{|c|}{ calhau Casca- terra } & \multicolumn{6}{|c|}{ composição granulométrica $(\mathrm{g} / \mathrm{kg})$} & & \multicolumn{2}{|c|}{ Argila Grau } & \multirow{2}{*}{$\begin{array}{l}\text { relaç. } \\
\text { silte }\end{array}$} & \multirow{2}{*}{$\begin{array}{c}\text { Densidade } \\
\mathrm{Kg} / \mathrm{dm}^{3}\end{array}$} \\
\hline & & & Lho & fina & AMG & AG & $\mathrm{AM}$ & AF & $\mathrm{AMF}$ & Areia & Silte & Argila & disp a & floc & & \\
\hline Tipo & prof. $\mathrm{cm}$ & $\%$ & $\%$ & $\%$ & & & & & & Total & & & $\%$ & $\%$ & Argila & Ds $D p$ \\
\hline A & $0-15$ & 0 & 2 & 98 & 10 & 100 & 350 & 350 & 30 & 840 & 60 & 100 & 2 & 80 & 0,6 & $1,422,56$ \\
\hline $\mathrm{C}$ & $15-50 / 70$ & 0 & 3 & 97 & 10 & 100 & 410 & 290 & 30 & 840 & 60 & 100 & 6 & 40 & 0,6 & $1,45 \quad 2,67$ \\
\hline $\mathrm{Cr} 1$ & $60-60$ & 5 & 9 & 86 & 10 & 130 & 380 & 370 & 10 & 900 & 20 & 80 & 2 & 75 & 0,2 & - \\
\hline $\mathrm{Cr} 2$ & $60-70$ & 0 & 2 & 98 & 10 & 70 & 380 & 370 & 30 & 860 & 40 & 100 & 4 & 60 & 0,4 & - \\
\hline
\end{tabular}

ATRIBUTOS QUIMICOS, DO PERFIL Nº 11

\begin{tabular}{|c|c|c|c|c|c|c|c|c|c|c|c|c|c|c|c|}
\hline \multicolumn{2}{|c|}{$\begin{array}{c}\text { Horiz e/ou } \\
\text { cam. }\end{array}$} & \multicolumn{2}{|c|}{$\mathrm{pH}$. } & \multicolumn{5}{|c|}{ Complexo sortivo $(\mathrm{mmol} / \mathrm{Kg})$} & \multicolumn{2}{|c|}{ Valor } & Valor & \multirow[t]{2}{*}{$\mathrm{V} \%$} & \multirow[t]{2}{*}{$\mathrm{m} \%$} & \multirow{2}{*}{$\begin{array}{c}\mathrm{P} \\
\mathrm{mg} / \mathrm{kg}\end{array}$} & \multirow{2}{*}{$\begin{array}{l}\text { C org. } \\
\text { g.kg-1 }\end{array}$} \\
\hline Tipo & Prof. cm & $\mathrm{H}_{2} \mathrm{O}$ & $\mathrm{KCl}$ & $\mathrm{Ca}^{2+}$ & $\mathrm{Mg}^{2+}$ & $\mathrm{K}^{+}$ & $\mathrm{Na}^{+}$ & $\mathrm{Al}^{3+}$ & $\mathrm{H}^{+}$ & $S$ & $\mathrm{~T}$ & & & & \\
\hline A & $0-15$ & 5.4 & 4.0 & 5 & 1 & 0,6 & 0,2 & 3 & 29 & 6,8 & 38,8 & 18 & 30 & 6 & 5,8 \\
\hline $\mathrm{C}$ & $15-50 / 70$ & 5.1 & 3.9 & 4 & 1 & 0,5 & 0,2 & 9 & 30 & 5,7 & 44,7 & 13 & 61 & 4 & 2,8 \\
\hline $\mathrm{Cr} 1$ & $50-60$ & 5.1 & 4.0 & 3 & 1 & 0,6 & 0,2 & 6 & 13 & 4,8 & 23,8 & 20 & 55 & 2 & 4,6 \\
\hline $\mathrm{Cr} 2$ & $60-70$ & 5.0 & 3.9 & 4 & 1 & 0,6 & 0,2 & 7 & 20 & 5,8 & 32,8 & 18 & 55 & 2 & 4,6 \\
\hline
\end{tabular}

ATRIBUTOS MINERALOGICOS DO PERFIL N ${ }^{\circ} 11$

\begin{tabular}{|c|c|c|c|c|c|c|c|c|c|c|c|c|}
\hline \multicolumn{2}{|c|}{ Horizonte (cam) } & \multicolumn{5}{|c|}{ ataque com $\mathrm{H}_{2} \mathrm{SO}_{4}$} & \multicolumn{2}{|c|}{ Relações } & \multicolumn{2}{|c|}{$\%$ da $\mathrm{AF}$} & \multicolumn{2}{|c|}{ DRX } \\
\hline Tipo & Prof. $(\mathrm{cm})$ & $\mathrm{SiO}_{2}$ & $\mathrm{Al}_{2} \mathrm{O}_{3}$ & $\mathrm{Fe}_{2} \mathrm{O}_{3}$ & $\mathrm{TiO}_{2}$ & $\mathrm{MnO}$ & $\mathrm{Ki}$ & $\mathrm{Kr}$ & Leves & Pesados & argila & silte \\
\hline $\mathrm{A}$ & $0-15$ & 1,21 & 1,18 & 0,29 & 0,19 & 0,03 & 1,75 & 1,50 & - & - & - & - \\
\hline C & $15-50 / 70$ & 9,42 & 2,37 & 0,33 & 0,27 & 0,03 & 1,73 & 1,59 & 99,5 & 0,5 & $\mathrm{C}, \mathrm{Mi}$ & $\mathrm{P}, \mathrm{Q}$ \\
\hline $\mathrm{Cr} 2$ & $60-70$ & 1,31 & 1,34 & 0,11 & 0,11 & 0,11 & 1,66 & 1,57 & 99,5 & 0,5 & $\mathrm{Mi}, \mathrm{C}$ & $\mathrm{P}, \mathrm{Q}$ \\
\hline
\end{tabular}

COMPOSIÇÃO QUÍMICA ELEMENTAL DA FRAÇĀO AREIA FINA DO PERFIL 11

\begin{tabular}{|c|c|c|c|c|c|c|c|c|c|c|c|c|}
\hline Hor/cam & & & & INF & FLUORE & ESCÊNC & IA DE R & AIO X & \%) & & & $\mathrm{Zr}$ \\
\hline Tipo & Prof $(\mathrm{cm})$ & $\mathrm{SiO}_{2}$ & $\mathrm{Al}_{2} \mathrm{O}_{3}$ & $\mathrm{Fe}_{2} \mathrm{O}_{3}$ & $\mathrm{TiO}_{2}$ & $\mathrm{MnO}$ & $\mathrm{CaO}$ & $\mathrm{MgO}$ & $\mathrm{K}_{2} \mathrm{O}$ & $\mathrm{Na}_{2} \mathrm{O}$ & $\mathrm{P}_{2} \mathrm{O}_{5}$ & ppm \\
\hline $\mathrm{A}$ & $0-15$ & 98,6666 & 0,4909 & 0,3817 & 0,1195 & 0,0124 & 0,0189 & 0,0000 & 0,0400 & 0,0099 & 0,0225 & 155 \\
\hline C & $15-50 / 70$ & 98,6866 & 0,7621 & 0,2568 & 0,0939 & 0,0003 & 0,0222 & 0,0000 & 0,0469 & 0,0258 & 0,0119 & 131 \\
\hline $\mathrm{Cr} 1$ & $50-60$ & 98,8780 & 0,2853 & 0,1022 & 0,0783 & 0,0026 & 0,0136 & 0,0000 & 0,0386 & 0,0151 & 0,0177 & 49 \\
\hline $\mathrm{Cr} 2$ & $60-70$ & 98,7220 & 0,4008 & 0,2438 & 0,1001 & 0,0084 & 0,0156 & 0,0000 & 0,0418 & 0,0058 & 0,0222 & 78 \\
\hline
\end{tabular}




\section{A. DESCRICCÃO GERAL}

PERFIL: $\mathrm{N}^{\circ} 12$

CLASSIFICACÃO: Cambissolo álico petroplíntico Tb A proeminente textura média, fase floresta subtropical subperennifolia, substrato arenito, relevo ondulado.

LOCALIZACCÃO: Fundo da propriedade do Austríaco $\pm 30 \mathrm{~m}$ a oeste do capão da parte alta.

COORD. UTM: E0513500/N7131700 UN PEDOGEOMÓRFICA: 1b

RELEVO LOCAL: ondulado

ALTITUDE: 370 m.s.n.m.

RELEVO REGIONAL: ondulado e forte ondulado

DECLIVE: 7\%

POSICCÃO TOP: ombro com direção Oeste

DIRECÃO: oeste

COMPRIMENTO: $50 \mathrm{~m}$

LITOLOGIA: Arenito arcosiano

FORMAČ̃̃O GEOL.: "Cerro hũ"

MAT. PARENTAL: saprólito de arenito arcosiano.

ROCHOSIDADE: não rochosa

EDREGOSIDADE: não pedregosa

PROF. DO LENCOL: $>2 \mathrm{~m}$

RENAGEM: moderadamente drenado

INUNDACCÕES: nula

EROSÃO: laminar moderado

VEGET. PRIMÁRIA: Floresta subtropical subperennifolia

USO ATUAL: pastoreio

PRODUTIVIDADE: baixa

CLIMA: temperado chuvoso (cfa)

ESCRITO POR: Sérgio M. Burgos Sosa

\section{B. DESCRIĊÃO MORFOLÓGICA}

A1 0-30 cm, bruno escuro (7.5 YR 3/2, úmido), bruno (7.5 YR 5/2, seco); franco-arenosa; moderado média granular e blocos subangulares; macio, friável, não plástico e não pegajoso; transição gradual e plana.

A2 30-60 cm; bruno escuro (7.5 YR 3/2, úmido), bruno (7.5 YR 5/3, seco); franco-arenosa; moderado média blocos subangulares; macio, friável, não plástico e não pegajoso; transição clara e ondulada.

Bi 60-85 cm, bruno escuro (7.5 YR 3/3, úmido), bruno claro (7.5 YR 6/3, seco); franco argiloarenosa; moderado media blocos subangulares; cerosidade fraca e pouca em poros e superfície de grãos; macio, friável, não plástico e não pegajoso; transição abrupta e ondulada.

F $\quad 85-87 \mathrm{~cm}$; vermelho escuro acinzentado (10 R 3/3, úmido e seco); muito duro; extremadamente firme; transição abrupta e ondulada.

Cr $87 \mathrm{~cm} \mathrm{+;} \mathrm{amarelo} \mathrm{(10} \mathrm{YR} \mathrm{7/6,} \mathrm{úmido),} \mathrm{bruno} \mathrm{muito} \mathrm{claro} \mathrm{(10} \mathrm{YR} \mathrm{8/4,} \mathrm{seco),} \mathrm{franco} \mathrm{arenoso;}$ muito duro, firme, não plástico e não pegajoso.

RAÍZES: poucas e muito finas no A1 e A2; raras e muito fina no $\mathrm{B}$, sem raízes no $\mathrm{F}$ e $\mathrm{Cr}$.

OBSERVAÇÕES: Presença de cascalhos em todos os horizontes em forma de concresões de ferro, poucas, pequenas, duras, irregulares, de cor bruno escuro nos horizontes A1 e A2, passando para frequentes na base do horizonte $\mathrm{Bi}$. 
ATRIBUTOS FÍSICOS DO PERFIL No 12

\begin{tabular}{|c|c|c|c|c|c|c|c|c|c|c|c|c|c|c|c|c|}
\hline Hori & zontes & calhat & casca- & terra & & & mposi & ção $\mathbf{g}$ & anulon & létrica \& & $/ \mathrm{kg}$ & & Argila & Grau & relaç. & $\begin{array}{c}\text { Densidad } \\
e\end{array}$ \\
\hline e/ou c & amadas & & lho & fina & AMG & AG & $\mathrm{AM}$ & $\mathrm{AF}$ & AMF & Areia & Silte & Argila & a disp a & floc & silte & $\mathrm{Kg} / \mathrm{dm}^{3}$ \\
\hline Tipo & $\begin{array}{c}\text { prof. } \\
\mathrm{cm}\end{array}$ & & & & & & & & & Total & & & $\%$ & $\%$ & Argila & Ds $D p$ \\
\hline Al & $0-30$ & 0 & 1 & 99 & 20 & 100 & 240 & 400 & 40 & 800 & 60 & 140 & 6 & 57 & 0,4 & $1,432,63$ \\
\hline A2 & $30-60$ & 0 & $\mathrm{x}$ & 99 & 20 & 110 & 240 & 370 & 40 & 780 & 60 & 160 & 10 & 38 & 0,4 & $1,342,60$ \\
\hline $\mathrm{Bi}$ & $60-85$ & 0 & 2 & 98 & 20 & 80 & 200 & 340 & 50 & 690 & 90 & 220 & 16 & 27 & 0,4 & $1,472,67$ \\
\hline $\mathrm{Cr}$ & $87+$ & 3 & 20 & 77 & 40 & 220 & 370 & 220 & 10 & 860 & 20 & 120 & 6 & 50 & 0,2 & - \\
\hline
\end{tabular}

\section{ATRIBUTOS QUIMICOS DO PERFIL N ${ }^{\circ} 12$}

\begin{tabular}{|c|c|c|c|c|c|c|c|c|c|c|c|c|c|c|c|}
\hline \multicolumn{2}{|c|}{ Horiz e/ou cam. } & \multicolumn{2}{|c|}{$\mathrm{pH}$. } & \multicolumn{6}{|c|}{ complexo sortivo $(\mathrm{mmol} / \mathrm{Kg})$} & \multicolumn{2}{|c|}{ Valor Valor } & \multirow[t]{2}{*}{$\mathrm{V} \%$} & \multirow[t]{2}{*}{$\mathrm{m} \%$} & \multirow{2}{*}{$\frac{\mathrm{P}}{\mathrm{mg} / \mathrm{kg}}$} & \multirow{2}{*}{$\frac{\text { C org. }}{\mathrm{g} \cdot \mathrm{kg}^{-1}}$} \\
\hline Tipo & Prof. $\mathrm{cm}$ & $\mathrm{H}_{2} \mathrm{O}$ & $\mathrm{KCl}$ & $\mathrm{Ca}^{2+}$ & $\mathrm{Mg}^{2+}$ & $\mathrm{K}^{+}$ & $\mathrm{Na}^{+}$ & $\mathrm{Al}^{3+}$ & $\mathrm{H}^{+}$ & $S$ & $\mathrm{~T}$ & & & & \\
\hline Al & $0-30$ & 4.7 & 3.7 & 15,0 & 1,0 & 1,0 & 0,2 & 12,0 & 42,0 & 17,2 & 71,2 & 24 & 41 & 4 & 8,6 \\
\hline A2 & $30-60$ & 4.6 & 3.7 & 5,0 & 1,0 & 0,4 & 0,2 & 21,0 & 47,0 & 6,6 & 74,6 & 9 & 76 & 4 & 7,5 \\
\hline $\mathrm{Bi}$ & $60-25$ & 4.6 & 3.6 & 6,0 & 1,0 & 0,5 & 0,2 & 23,0 & 45,0 & 7,7 & 75,7 & 10 & 75 & 5 & 7,5 \\
\hline $\mathrm{Cr}$ & $87+$ & 4.8 & 3.9 & 4,0 & 1,0 & 0,2 & 0,2 & 7,0 & 20,0 & 5,4 & 32,4 & 17 & 56 & 2 & 2,8 \\
\hline
\end{tabular}

ATRIBUTOS MINERALOGICOS DO PERFIL No 12

\begin{tabular}{|c|c|c|c|c|c|c|c|c|c|c|c|c|}
\hline \multicolumn{2}{|c|}{ Horizonte (cam) } & \multicolumn{5}{|c|}{ ataque $\operatorname{com~} \mathrm{H}_{2} \mathrm{SO}_{4}$} & \multicolumn{2}{|c|}{ Relações } & \multicolumn{2}{|c|}{$\%$ da $\mathrm{AF}$} & \multicolumn{2}{|c|}{ DRX } \\
\hline Tipo & Prof. $(\mathrm{cm})$ & $\mathrm{SiO}_{2}$ & $\mathrm{Al}_{2} \mathrm{O}_{3}$ & $\mathrm{Fe}_{2} \mathrm{O}_{3}$ & $\mathrm{TiO}_{2}$ & $\mathrm{MnO}$ & $\mathrm{Ki}$ & $\mathrm{Kr}$ & Leves & Pesados & argila & silte \\
\hline$\overline{\mathrm{A} 1}$ & $0-30$ & 2,12 & 2,63 & 0,23 & 0,22 & 0,01 & 1,37 & 1,29 & - & - & - & - \\
\hline $\mathrm{Bi}$ & $60-85$ & 5,35 & 5,25 & 0,29 & 0,47 & 0,01 & 1,73 & 1,67 & 99,5 & 0,5 & $\mathrm{C}, \mathrm{V}, \mathrm{Mi}$ & $P, Q$ \\
\hline $\mathrm{F}$ & $85-87$ & 6,57 & 5,00 & 9,42 & 1,24 & 0,01 & 2,23 & 1,01 & - & - & - & - \\
\hline $\mathrm{Cr}$ & $87 \mathrm{~cm}+$ & 2,02 & 1,86 & 0,32 & 0,31 & 0,01 & 1,84 & 1,66 & 99,5 & 0,5 & $\mathrm{C}, \mathrm{Mi}$ & $P, Q$ \\
\hline
\end{tabular}

COMPOSIÇÃO QUÍMICA ELEMENTAL DA FRAÇÃO AREIA FINA DO PERFIL 12

\begin{tabular}{|c|c|c|c|c|c|c|c|c|c|c|c|}
\hline Horiz/cam & & & & FLUORF & ISCÊNC & IA DE R & AIO X & & & & $\mathrm{Zr}$ \\
\hline Tipo & $\mathrm{SiO}_{2}$ & $\mathrm{Al}_{2} \mathrm{O}_{3}$ & $\mathrm{Fe}_{2} \mathrm{O}_{3}$ & $\mathrm{TiO}_{2}$ & $\mathrm{MnO}$ & $\mathrm{CaO}$ & $\mathrm{MgO}$ & $\mathrm{K}_{2} \mathrm{O}$ & $\mathrm{Na}_{2} \mathrm{O}$ & $\mathrm{P}_{2} \mathrm{O}_{5}$ & $\mathrm{ppm}$ \\
\hline A 1 & 96,3681 & 0,7016 & 0,7100 & 0,0894 & 0,0059 & 0,0224 & 0,0000 & 0,0262 & 0,0207 & 0,0120 & 78 \\
\hline A2 & 98,5961 & 0,5560 & 0,2382 & 0,0992 & 0,0017 & 0,0333 & 0,0023 & 0,0340 & 0,2415 & 0,0180 & 85 \\
\hline B1 & 98,3504 & 0,5786 & 0,2651 & 0,0929 & 0,0015 & 0,0290 & 0,0000 & 0,0347 & 0,0214 & 0,0177 & 77 \\
\hline $\mathrm{Cr}$ & 98,4889 & 0,5260 & 0,5352 & 0,1236 & 0,0033 & 0,0166 & 0,0000 & 0,0595 & 0,0179 & 0,0203 & 62 \\
\hline
\end{tabular}




\section{A. DESCRIČ̃̃O GERAL}

PERFIL: $\mathrm{N}^{\circ} 13$

CLASSIFICACCÃO: Latossolo Vermelho Amarelo álico plíntico A prominente textura media, fase floresta subtropical subperennnifolia, substrato arenito, relevo ondulado.

LOCALIZACCÃO: $20 \mathrm{~m}$ ao leste do arroio no fundo da propriedade do Austríaco.

COORD. UTM: E0513280/N7131600 UN PEDOGEOMÓRFICA: 1b

RELEVO LOCAL: ondulado

ALTITUDE: 350 m.s.n.m.

DECLIVE: $10 \%$

RELEVO REGIONAL: ondulado e forte ondulado

DIRECẼO: oeste POSIČ̃̃O TOP: Tercio inferior

LITOLOGIA: Arenito arcosiano

COMPRIMENTO: $200 \mathrm{~m}$

ROCHOSIDADE: não rochosa

FORMACẼO GEOL.: "Cerro hũ"

PROF. DO LENCOL: $>2 \mathrm{~m}$

MAT. PARENTAL: saprólito de arenito arcosiano

PEDREGOSIDADE: não pedregosa

DRENAGEM: moderadamente drenado

INUNDACÕES: nula

EROSÃO: em sulcos, forte

VEGET. PRIMÁRIA: Floresta subtropical subperennifolia

USO ATUAL: pastoreio

PRODUTIVIDADE: baixa

CLIMA: temperado chuvoso (cfa)

DESCRITO POR: Sérgio M. Burgos Sosa

\section{B. DESCRIČ̃̃O MORFOLÓGICA}

Al 0-20 cm, bruno escuro (7.5 YR 3/2, úmido), bruno escuro (7.5 YR 4/3, seco); franco argiloarenosa; fraca média granular; macio, friável, não plástico e não pegajoso; transição difusa e plana.

A2 20-75 cm; bruno escuro (7.5 YR 3/4, úmido), bruno escuro (7.5 YR 4/4, seco); franco argiloarenosa; fraca média granular e blocos subangulares; macio, friável, não plástico e não pegajoso; transição gradual e plana.

$\mathrm{AB}$ 75-100 cm; bruno escuro (7.5 YR 4/4, úmido), bruno forte (7.5 YR 5/6, seco); franco argiloarenosa; fraca media blocos subangulares; cerosidade fraca e pouca em poros e superfície dos grãos; macio, friável, ligeiramente plástico e ligeiramente pegajoso; transição gradual e plana.

Bw 100-140/160 cm; bruno forte (7.5 YR 4/6), úmido); amarelo avermelhado (7.5 YR 6/6, seco), franco argila-arenosa; moderado muito grande blocos subangulares; cerosidade fraca e pouca em canais, inter-grãos e superfície dos grãos; macio, muito friável, plástico e ligeiramente pegajoso; transição descontínua e gradual.

Bwf 140/160-180/190 cm; bruno forte (7.5 YR 4/6, úmido); amarelo avermelhado (7.5 YR 6/6, seco); mosqueados comuns médio prominente de cor bruno amarelado escuro (10 YR 3/6, úmido), franco argila-arenosa; moderado grande blocos subangulares; cerosidade fraca e pouca em superfície dos grãos e inter-grãos; macio, muito friável, ligeiramente plástico e ligeiramente pegajoso; transição abrupta e irregular.

F $180 / 190 \mathrm{~cm} \mathrm{+;} \mathrm{vermelho} \mathrm{escuro} \mathrm{acinzentado} \mathrm{(10} \mathrm{R} \mathrm{3/2,} \mathrm{úmido),} \mathrm{vermelho} \mathrm{acinzentado} \mathrm{(10} \mathrm{R}$ $4 / 2$, seco) areia franca; extremamente duro e extremamente firme.

RAÍZES: muito finas no $\mathrm{AB}$ e $\mathrm{Bi}$; raras e muito fina no $\mathrm{Bif}$.

OBSERVAÇÕES: Concresões de ferro, poucas, pequenas, duras, irregulares de cor bruno escuro no $\mathrm{Bi}$ Bif. 
ATRIBUTOS FÍSICOS DO PERFIL $\mathrm{N}^{\circ} 13$

\begin{tabular}{|c|c|c|c|c|c|c|c|c|c|c|c|c|c|c|c|c|c|}
\hline \multicolumn{2}{|c|}{$\begin{array}{l}\text { Horizontes } \\
\text { e/ou camadas }\end{array}$} & \multirow[t]{2}{*}{$\begin{array}{c}\text { Calha } \\
\text { u }\end{array}$} & \multirow[t]{2}{*}{$\begin{array}{l}\text { casca- } \\
\text { lho }\end{array}$} & \multirow[t]{2}{*}{ terra } & AMG & \multicolumn{3}{|c|}{ Composição Granulometrica g/Kg } & anulon & netrica & & Argil & \multicolumn{5}{|c|}{$\begin{array}{l}\text { Argila Grau Relaç. Densidad } \\
\mathrm{e} \\
\text { a disp floc. Silte/ } \mathrm{Kg} / \mathrm{dm}^{3}\end{array}$} \\
\hline Tipo & Prof. $\mathrm{cm}$ & & & & & & & & & Total & & & & $\%$ & Argila & Ds & Dr \\
\hline A1 & & 0 & $\mathrm{x}$ & & 10 & 90 & & & 10 & 690 & 110 & 200 & & 60 & 0,5 & 1,17 & 2,63 \\
\hline A2 & & 0 & $x$ & 99 & 10 & 90 & 260 & 290 & 20 & 10 & 130 & 20 & & & 0,6 & 1,40 & 2,60 \\
\hline$A B$ & & 0 & $\mathrm{x}$ & 99 & 20 & 70 & 230 & 300 & 30 & 650 & 130 & 220 & 2 & 91 & 0,6 & 1,40 & 2,67 \\
\hline $\mathrm{Bw}$ & $100-140 / 160$ & 0 & $\mathrm{x}$ & 99 & 20 & 60 & 200 & 280 & 30 & 590 & 100 & 310 & 2 & 94 & 0,3 & 1,39 & 2,60 \\
\hline Bwf & $\begin{array}{c}140 / 160- \\
180 / 190\end{array}$ & 3 & 3 & 94 & 20 & 70 & 200 & 240 & 40 & 570 & 100 & 330 & 2 & 94 & 0,3 & 1,43 & 2,70 \\
\hline $\mathrm{F}$ & $180 / 190+$ & 0 & 6 & 94 & 110 & 250 & 300 & 160 & 20 & 840 & 60 & 100 & 2 & 80 & 0,6 & - & - \\
\hline
\end{tabular}

ATRIBUTOS QUIMICOS, DO PERFIL N 13

\begin{tabular}{|c|c|c|c|c|c|c|c|c|c|c|c|c|c|c|c|}
\hline \multicolumn{2}{|c|}{ Horiz e/ou cam. } & \multicolumn{2}{|c|}{ PH. } & \multicolumn{6}{|c|}{ complexo sortivo $(\mathrm{mmol} / \mathrm{Kg})$} & \multirow{2}{*}{$\frac{\text { Valor }}{S}$} & \multirow{2}{*}{$\frac{\text { Valor }}{T}$} & \multirow[t]{2}{*}{$\mathrm{V} \%$} & \multirow[t]{2}{*}{$\mathrm{m} \%$} & \multirow{2}{*}{\multicolumn{2}{|c|}{$\begin{array}{c}\mathrm{P} \quad \mathrm{C} \text { org. } \\
\mathrm{mg} / \mathrm{kg} \mathrm{g} \cdot \mathrm{kg}^{-1}\end{array}$}} \\
\hline Tipo & Prof. cm & $\mathrm{H}_{2} \mathrm{O}$ & $\mathrm{KCl}$ & $\mathrm{Ca}^{2+}$ & $\mathrm{Mg}^{2+}$ & $\mathrm{K}^{+}$ & $\mathrm{Na}^{+}$ & $\mathrm{Al}^{3+}$ & $\mathrm{H}^{+}$ & & & & & & \\
\hline$\overline{A 1}$ & $0-20$ & 4.7 & 3.8 & 10 & 2 & 1,5 & 0,2 & 12 & 50 & 13,7 & 75,7 & 18 & 47 & 6 & 16,0 \\
\hline A2 & $20-75$ & 4.7 & 3.8 & 6 & 2 & 0,7 & 0,2 & 17 & 37 & 8,9 & 62,9 & 14 & 65 & 3 & 7,5 \\
\hline$A B$ & $75-100$ & 4.7 & 3.7 & 5 & 2 & 1,5 & 0,2 & 19 & 30 & 8,7 & 57,7 & 15 & 68 & 4 & 5,7 \\
\hline $\mathrm{Bw}$ & $100-140 / 160$ & 4.7 & 3.7 & 5 & 2 & 2,1 & 0,2 & 26 & 31 & 9,3 & 66,3 & 14 & 74 & 4 & 2,8 \\
\hline Bwf & $\begin{array}{l}140 / 160- \\
180 / 190\end{array}$ & 4.8 & 3.7 & 5 & 2 & 1,2 & 0,2 & 24 & 30 & 8,4 & 62,4 & 13 & 74 & 4 & 2,8 \\
\hline F & $180 / 190+$ & 4.9 & 4.0 & 4 & 1 & 0,9 & 0.2 & 4 & 25 & 6,1 & 35,1 & 17 & 40 & 3 & 2,8 \\
\hline
\end{tabular}

ATRIBUTOS MINERALOGICOS DO PERFIL N ${ }^{\circ} 13$

\begin{tabular}{|c|c|c|c|c|c|c|c|c|c|c|c|c|}
\hline \multicolumn{2}{|c|}{ Horizonte (cam) } & \multicolumn{5}{|c|}{ ataque $\operatorname{com~} \mathrm{H}_{2} \mathrm{SO}_{4}$} & \multicolumn{2}{|c|}{ Relações } & \multicolumn{2}{|c|}{$\%$ da AF } & \multicolumn{2}{|c|}{ DRX } \\
\hline Tipo & Prof. $(\mathrm{cm})$ & $\mathrm{SiO}_{2}$ & $\mathrm{Al}_{2} \mathrm{O}_{3}$ & $\mathrm{Fe}, \mathrm{O}_{3}$ & $\mathrm{TiO}_{2}$ & $\mathrm{MnO}$ & $\mathrm{Ki}$ & $\mathrm{Kr}$ & Leves & Pesados & argila & silte \\
\hline$\overline{A 1}$ & $0-20$ & 4,55 & 3,92 & 0,54 & 0,31 & 0,06 & 1,97 & 1,81 & - & - & $-\ldots$ & - \\
\hline $\mathrm{Bw}$ & $100-140 / 160$ & 9,09 & 7,36 & 0,90 & 0,61 & 0,01 & 2,10 & 1,95 & 99,5 & 0,5 & $\mathrm{C}, \mathrm{Mi}, \mathrm{V}$ & $P, Q$ \\
\hline $\mathrm{F}$ & $180 / 190+$ & 2,02 & 2,89 & 18,16 & 1,81 & 0,10 & 1,19 & 0,24 & 85,0 & 15,0 & C, $\mathrm{Mi}, \mathrm{V}$ & $P, Q$ \\
\hline
\end{tabular}

COMPOSIÇÃO QUÍMICA ELEMENTAL DA FRAÇÃO AREIA FINA DO PERFIL 13

\begin{tabular}{cccccccccccc}
\hline Horiz/cam & \multicolumn{8}{c}{ INFLUORESCÊNCIA DE RAIO X (\%) } \\
\hline & $\mathrm{SiO}_{2}$ & $\mathrm{Al}_{2} \mathrm{O}_{2}$ & $\mathrm{Fe}_{2} \mathrm{O}_{3}$ & $\mathrm{TiO}_{2}$ & $\mathrm{MnO}$ & $\mathrm{CaO}$ & $\mathrm{MgO}$ & $\mathrm{K}_{2} \mathrm{O}$ & $\mathrm{Na}_{2} \mathrm{O}$ & $\mathrm{P}_{2} \mathrm{O}_{5}$ & $\mathrm{Zr}$ \\
\hline $\mathrm{A} 1$ & 97,7676 & 0,4940 & 0,4224 & 0,0986 & 0,0066 & 0,0218 & 0,0000 & 0,0274 & 0,0327 & 0,0130 & 57 \\
$\mathrm{~A} 2$ & 98,7075 & 0,4506 & 0,3972 & 0,1059 & 0,0047 & 0,0200 & 0,0000 & 0,0254 & 0,0287 & 0,0123 & 80 \\
$\mathrm{AB}$ & 98,5279 & 0,4710 & 0,4148 & 0,0993 & 0,0031 & 0,0155 & 0,0099 & 0,0271 & 0,0099 & 0,0124 & 92 \\
$\mathrm{Bw}$ & 98,5417 & 0,5285 & 0,4207 & 0,0993 & 0,0017 & 0,0426 & 0,0000 & 0,0327 & 0,0174 & 0,0161 & 107 \\
$\mathrm{Bwf}$ & 98,7388 & 0,4173 & 0,2714 & 0,1086 & 0,0017 & 0,0166 & 0,0000 & 0,0275 & 0,0181 & 0,0121 & 126 \\
$\mathrm{~F}$ & 74.9111 & 1.8379 & 19.2983 & 0.0469 & 0,1404 & 0.0382 & 0.0016 & 0.0734 & 0.0813 & 1,0202 & 88 \\
\hline
\end{tabular}


PERFIL: No 21

\section{A. DESCRIČÃO GERAL}

CLASSIFICAC̄̃̃O: Podzólico Vermelho amarelo álico Tb A moderado textura media/argilosa, fase floresta subtropical subperennifolia, substrato arenito, relevo ondulado.

LOCALIZACẼ̃O: $100 \mathrm{~m}$ ao oeste do capão da parte mais alta na propriedade do Austríaco.

COORD. UTM: E0513750/N7131850 UN PEDOGEOMÓRFICA: 1c

RELEVO LOCAL: ondulado

ALTITUDE: 370 m.s.n.m.

DECLIVE: $5 \%$

DIREĈ̃̃: leste

LITOLOGIA: Arenito arcosiano

ROCHOSIDADE: nula

PROF. DO LENCOL: $>2 \mathrm{~m}$

INUNDACÕES: nula

EROSÃO: laminar moderado

PRODUTIVIDADE: media

DESCRITO POR: Sérgio M. Burgos Sosa

RELEVO REGIONAL: ondulado e forte ondulado

POSIČ̃̃O TOP: hombro

COMPRIMENTO: $100 \mathrm{~m}$

FORMACÃO GEOL.: "Cerro hü"

MAT. PARENTAL: saprolito de arenito arcosiano.

PEDREGOSIDADE: nula

DRENAGEM: bem drenado

VEGET. PRIMÁRIA: Floresta subtropical subperennifolia

USO ATUAL: agrícola

CLIMA: temperado chuvoso (cfa)

\section{B. DESCRIĊÃO MORFOLÓGICA}

Ap 0-15 cm, bruno avermelhado escuro (5 YR 3/3, úmido), bruno avermelhado (5 YR 4/4, seco); franco-arenosa; moderado média granular; macio, friável, não plástico e não pegajoso; transição gradual e plana.

A2 15-60 cm; bruno avermelhado escuro (2.5 YR 3/4, úmido), vermelho amarelado (5 YR 4/6, seco); franca argila-arenosa; moderado média granular e blocos subangulares; macio, friável, não plástico e não pegajoso; transição gradual e plana.

$\mathrm{AB}$ 60-80 cm; bruno avermelhado escuro (2.5 YR 3/4, úmido), vermelho amarelado (5 YR 4/6, seco); franco argilo-arenosa; moderado grande blocos subangulares; ligeiramente duro, friável, não plástico e não pegajoso, transição gradual e plano.

Btl 80-115 cm; bruno avermelhado escuro (2.5 YR 3/4), úmido); vermelho amarelado (5 YR 4/6, seco), franco argilo-arenosa; moderado grande blocos subangulares; cerosidade fraca e pouca em canais e superfície de agregados; ligeiramente duro, muito friável, plástico e pegajoso; transição gradual e plana.

Bt2 115-135 cm; bruno avermelhado escuro (2.5 YR 3/4, úmido); vermelho (2.5 YR 4/6, seco); argila arenosa; moderado grande blocos subangulares; cerosidade fraca e pouca inter-grãos; ligeiramente duro, muito friável, plástico e ligeiramente pegajoso; transição difusa e plana.

C 135-170/180 cm; vermelho (2.5 YR 4/6, úmido), vermelho (2.5 YR 4/8, seco), franco argilaarenosa; fraca media blocos subangulares; ligeiramente duro, muito friável, ligeiramente plástico e ligeiramente pegajoso; transição abrupta e descontínua.

Cr 170/180 cm +; amarelo avermelhado (5 YR 6/8, úmido), amarelo avermelhado (5 YR 7/6, seco), mosqueado vermelho escuro (2.5 YR 3/6, úmido), comum, grande e proeminente. Areia franca; maciço, muito duro, friável, não plástico e não pegajoso (rocha intemperizada).

RAIZES: comuns e finas no $\mathrm{Ap}, \mathrm{A} 2$ e $\mathrm{AB}$; poucas e muito finas no $\mathrm{Btl}$ e $\mathrm{Bt} 2$; raras e muito finas no $\mathrm{C}$. OBSERVAÇÕES: cascalho em forma de concresōes de ferro, poucas, duras, pequenas irregulares de cor bruno escuro em todo o perfil. 
ATRIBUTOS FÍSICOS DO PERFIL N ${ }^{\circ} 21$

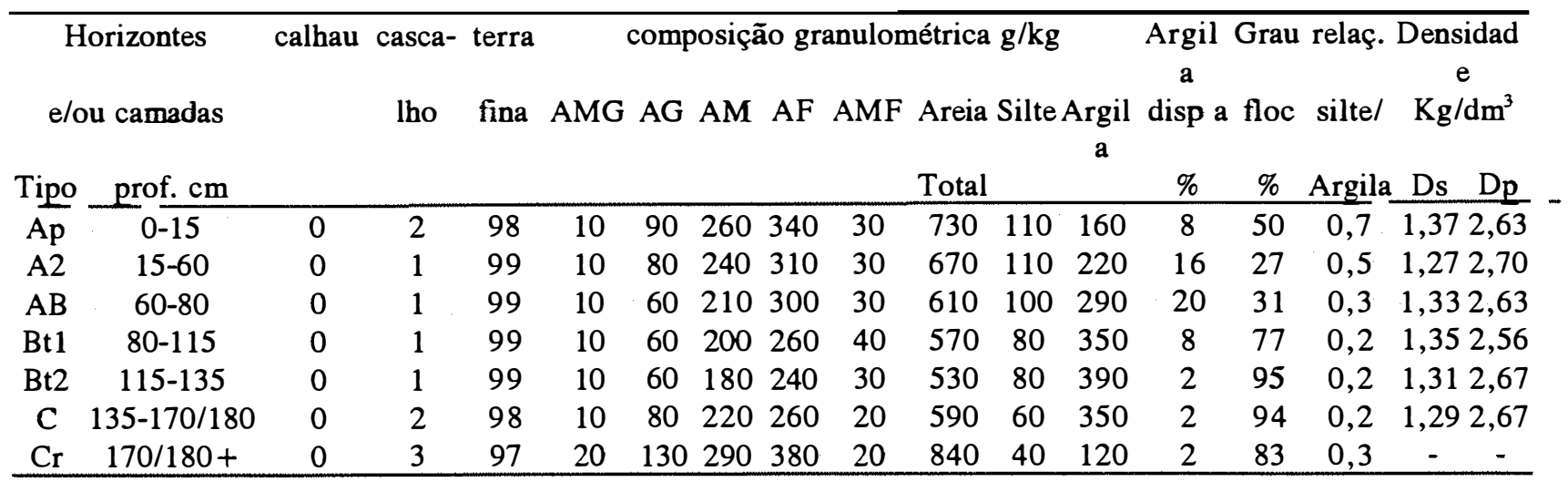

ATRIBUTOS QUIMICOS, DO PERFIL N ${ }^{\circ} 21$

\begin{tabular}{|c|c|c|c|c|c|c|c|c|c|c|c|c|c|c|c|}
\hline \multicolumn{2}{|c|}{ Horiz e/ou cam. } & \multicolumn{2}{|c|}{$\mathrm{pH}$. } & \multicolumn{6}{|c|}{ Complexo sortivo (mmol/Kg) } & \multicolumn{2}{|c|}{ Valor Valor } & \multirow[t]{2}{*}{$\mathrm{V} \%$} & \multirow[t]{2}{*}{$\mathbf{m} \%$} & \multirow{2}{*}{$\frac{\mathrm{P}}{\mathrm{mg} / \mathrm{kg}}$} & \multirow{2}{*}{$\frac{\mathrm{C} \text { org. }}{\mathrm{g} \cdot \mathrm{kg}^{-1}}$} \\
\hline Tipo & Prof. $\mathrm{cm}$ & $\mathrm{H}_{2} \mathrm{O}$ & $\mathrm{KCl}$ & $\mathrm{Ca}^{2+}$ & $\mathrm{Mg}^{2+}$ & $\mathrm{K}^{+}$ & $\mathrm{Na}^{+}$ & $\mathrm{Al}^{3+}$ & $\mathrm{H}^{+}$ & $S$ & $\mathrm{~T}$ & & & & \\
\hline Ap & $0-15$ & 5.4 & 4.1 & 11 & 2 & 2,8 & 0,2 & 2 & 33 & 16,0 & 51,0 & 31 & 11 & 6 & 4,6 \\
\hline $\mathrm{A} 2$ & $15-60$ & 5.2 & 3.9 & 17 & 3 & 2,0 & 0,2 & 5 & 34 & 22,2 & 61,2 & 36 & 18 & 4 & 7,5 \\
\hline $\mathrm{AB}$ & $60-80$ & 5.0 & 3.7 & 18 & 3 & 1,2 & 0,2 & 10 & 35 & 22,4 & 67,4 & 33 & 31 & 10 & 5,7 \\
\hline Bt1 & $80-115$ & 4.8 & 3.5 & 16 & 3 & 1,1 & 0,2 & 16 & 40 & 20,3 & 76,3 & 27 & 44 & 7 & 4,6 \\
\hline $\mathrm{Bt} 2$ & $115-135$ & 4.7 & 3.4 & 11 & 3 & 1,4 & 0,2 & 24 & 38 & 15,6 & 77,6 & 20 & 61 & 7 & 2,8 \\
\hline C & $135-170 / 180$ & 4.6 & 3.4 & 9 & 3 & 0,9 & 0,2 & 24 & 32 & 12,1 & 68,1 & 18 & 66 & 9 & 4,6 \\
\hline $\mathrm{Cr}$ & $170 / 180+$ & 4.7 & 3.5 & 5 & 1 & 0,6 & 0,2 & 11 & 21 & 6,8 & 38,8 & 17 & 62 & 4 & 7,5 \\
\hline
\end{tabular}

ATRIBUTOS MINERALOGICOS DO PERFIL No 21

\begin{tabular}{|c|c|c|c|c|c|c|c|c|c|c|c|c|}
\hline \multicolumn{2}{|c|}{ Horizonte (cam) } & \multicolumn{4}{|c|}{ 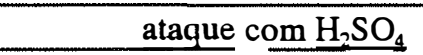 } & \multicolumn{3}{|c|}{ Relaçōes } & \multicolumn{2}{|c|}{$\%$ da AF } & \multicolumn{2}{|c|}{ DRX } \\
\hline Tipo & Prof. $(\mathrm{cm})$ & $\mathrm{SiO}_{2}$ & $\mathrm{Al}_{2} \mathrm{O}_{3}$ & $\mathrm{Fe}_{2} \overline{\mathrm{O}_{3}}$ & $\mathrm{TiO}_{2}$ & $\mathrm{Mn} \mathrm{O}$ & $\mathrm{Ki}$ & $\mathrm{Kr}$ & Leves & Pesados & argila & silte \\
\hline$\overline{\mathrm{Ap}}$ & $0-15$ & 4,00 & 3,11 & 1,07 & 0,34 & 0,04 & 2,19 & 1,79 & 99,5 & 0,5 & & - \\
\hline $\mathrm{Bt} 2$ & $80-115$ & 9,90 & 8,44 & 1,59 & 0,69 & 0,01 & 1,99 & 1,78 & 99,5 & 0,5 & $\mathrm{C}, \mathrm{Mi}, \mathrm{V}$ & $P, Q$ \\
\hline $\mathrm{Cr}$ & $170 / 180$ & 3,74 & 3,19 & 0,14 & 0,37 & 0,01 & 1,99 & 1,94 & 99,5 & 0,5 & $\mathrm{C}, \mathrm{Mi}, \mathrm{V}$ & $P, Q$ \\
\hline
\end{tabular}

COMPOSIÇÃO QUÍMICA ELEMENTAL DA FRAÇÃO AREIA FINA DO PERFIL 21

\begin{tabular}{cccccccccccc}
\hline Horiz/cam & \multicolumn{8}{c}{ INFLUORESCENCIA DE RAIO X } & $\%$ & & \multicolumn{3}{c}{$\mathrm{Zr}$} \\
\hline & $\mathrm{SiO}_{2}$ & $\mathrm{Al}_{2} \mathrm{O}_{3}$ & $\mathrm{Fe}_{2} \mathrm{O}_{3}$ & $\mathrm{TiO}$ & $\mathrm{MnO}$ & $\mathrm{CaO}$ & $\mathrm{MgO}$ & $\mathrm{K}_{2} \mathrm{O}$ & $\mathrm{Na}_{2} \mathrm{O}$ & $\mathrm{P}_{2} \mathrm{O}_{5}$ & $\mathrm{ppm}$ \\
\hline $\mathrm{Ap}$ & 98,4363 & 0,5156 & 0,4901 & 0,0954 & 0,0076 & 0,0231 & 0,0000 & 0,0270 & 0,0307 & 0,0148 & 105 \\
$\mathrm{~A} 2$ & 98,2335 & 0,6345 & 0,4742 & 0,1055 & 0,0083 & 0,0354 & 0,0142 & 0,0329 & 0,0465 & 0,0169 & 215 \\
$\mathrm{AB}$ & 98,6283 & 0,5452 & 0,4903 & 0,0839 & 0,0056 & 0,0151 & 0,0000 & 0,0256 & 0,0284 & 0,0183 & 51 \\
$\mathrm{Bt} 1$ & 98,4644 & 0,5289 & 0,4859 & 0,0952 & 0,0028 & 0,0617 & 0,0000 & 0,0285 & 0,0189 & 0,0122 & 73 \\
$\mathrm{Bt} 2$ & 98,4899 & 0,5096 & 0,5026 & 0,0983 & 0,0018 & 0,0209 & 0,0000 & 0,0253 & 0,0204 & 0,0118 & 47 \\
$\mathrm{C}$ & 96,5131 & 0,8595 & 0,4863 & 0,1173 & 0,0020 & 0,0966 & 0,1989 & 0,0294 & 0,0921 & 0,0210 & 132 \\
$\mathrm{Cr}$ & 98,3787 & 0,6675 & 0,3040 & 0,0805 & 0,0026 & 0,0351 & 0,0000 & 0,0665 & 0,0227 & 0,0226 & 16 \\
\hline
\end{tabular}


PERFIL: No 22

\section{A. DESCRIĊÃO GERAL}

CLASSIFICACÃO: Podzolico Vermelho-amarelo distrófico Tb A moderado textura media/argiloso, fase floresta subtropical subperennifolia, substrato arenito, relevo ondulado.

LOCALIZACC̃̃O: $100 \mathrm{~m}$ a Oeste do arroio perto da casa na propriedade do José Zevallos.

COORD. UTM: E0514050/N7132050 UN PEDOGEOMÓRFICA: 1d

RELEVO LOCAL: ondulado

ALTITUDE: 340 m.s.n.m.

DECLIVE: $14 \%$

RELEVO REGIONAL: ondulado e forte ondulado

DIRECÃO: leste

POSIČ̃̃O TOP: Tercio inferior

LITOLOGIA: Arenito arcosiano

COMPRIMENTO: $100 \mathrm{~m}$

ROCHOSIDADE: nula

FORMAČ̃̃O GEOL.: "Cerro hũ "

PROF. DO LENCOL: $>2 \mathrm{~m}$

MAT. PARENTAL: saprólito de arenito arcosiano.

PEDREGOSIDADE: nula

INUNDACÕES: nula

DRENAGEM: bem drenado

EROSÃO: em sulcos, forte

VEGET. PRIMÁRIA: Floresta subtropical subperennifolia

USO ATUAL: agrícola anual

PRODUTIVIDADE: media

DESCRITO POR: Sérgio M. Burgos Sosa

CLIMA: temperado chuvoso (cfa)

\section{B. DESCRIĊÃO MORFOLÓGICA}

Ap 0-20 cm, bruno escuro (7.5 YR 4/3, úmido), bruno escuro (7.5 YR 4/4, seco); franco-arenosa; moderado média granular; macio, friável, ligeiramente plástico e ligeiramente pegajoso; transição gradual e plana.

A2 20-50 cm; bruno avermelhado escuro (2.5 YR 3/4, úmido), bruno avermelhado (5 YR 4/4, seco); franco-arenosa; moderado média blocos subangulares; macio, friável, ligeiramente plástico e pegajoso; transição gradual e plana.

$\mathrm{AB} \quad 50-80 \mathrm{~cm}$; bruno avermelhado escuro (2.5 YR 3/3, úmido), vermelho (2.5 YR 4/6, seco); franca argilo-arenosa; moderado media blocos subangulares; cerosidade fraca e pouca em canais; duro, friável, plástico e pegajoso; transição gradual e plana.

Bt 1 80-110 cm; bruno avermelhado escuro (2.5 YR 3/4, úmido); vermelho escuro (2.5 YR 3/6, seco), argila arenosa; forte grande a muito grande blocos subangulares; cerosidade fraca, pouca, em canais e superfície de agregados; muito duro, muito friável, plástico e pegajoso; transição difusa e plana.

Bt2 110-150 cm; bruno avermelhado escuro (2.5 YR 3/4, úmido); vermelho escuro (2.5 YR 3/6, seco), argila arenosa; forte grande blocos subangulares, cerosidade moderado, pouca em canais $\mathrm{e}$ superfície de agregados; duro, muito friável, plástico e pegajoso; transição difusa e plana.

Bt3 150-180/190 cm; vermelho escuro (2.5 YR 3/6, úmido); vermelho (2.5 YR 4/6, seco); argila arenosa; moderado grande blocos subangulares; cerosidade fraca e pouca inter-grãos; duro, friável, plástico e ligeiramente pegajoso; transição abrupta e descontínua.

Cr 180/190-200 cm, amarelo brunado (10 YR 6/8, úmido), amarelo (10 YR 7/8, seco) e cinzento claro (10 YR 7/2, úmido), branco (10 YR 2/2, seco); mosqueado vermelho escuro (2.5 YR 3/6, úmido), abundante, grande e proeminente.

RAIZES: poucas e finas no $\mathrm{A} 1$, comuns e finas no $\mathrm{A} 2$ e $\mathrm{AB}$, poucos e muito finas no $\mathrm{Bt} 1$ e $\mathrm{Bt} 2$ e raras e muito finas no BC.

OBSERVAÇÕES: poucos cascalhos em todo o perfil, na forma de concresões pequenas de ferro duras e irregulares de cor bruno escuro. 
ATRIBUTOS FÍSICOS DO PERFIL $\mathrm{N}^{\circ} 22$

\begin{tabular}{|c|c|c|c|c|c|c|c|c|c|c|c|c|c|c|c|c|c|}
\hline \multirow{2}{*}{\multicolumn{2}{|c|}{$\begin{array}{l}\text { Horizontes } \\
\text { e/ou camadas }\end{array}$}} & \multicolumn{3}{|c|}{ calhau casca- terra } & & \multicolumn{6}{|c|}{ Composição Granulometrica g/Kg } & & \multicolumn{5}{|c|}{ Argila Grau Relaç. Densidade } \\
\hline & & & lho & fina & AMG & AG & $\mathrm{AM}$ & $\mathrm{AF}$ & AMF & Areia & Silte & Argil & $\operatorname{disp}$ & floc. & Silte/ & $\mathrm{Kg} /$ & $\mathrm{dm}^{3}$ \\
\hline Tipo & Prof. cm & & & & & & & & & Total & & & $\%$ & $\%$ & Argila & Ds & $\mathrm{Dr}$ \\
\hline Ap & $0-20$ & 0 & 1 & 99 & 10 & 90 & 270 & 310 & 30 & 710 & 150 & 140 & 8 & 43 & 1,1 & 1,43 & 2,63 \\
\hline A2 & $20-50$ & 0 & 1 & 99 & 10 & 70 & 250 & 330 & 20 & 680 & 140 & 180 & 12 & 33 & 0,8 & 1,39 & 2,63 \\
\hline$A B$ & $50-80$ & 0 & $\mathrm{x}$ & 99 & 10 & 60 & 240 & 310 & 40 & 630 & 130 & 240 & 4 & 83 & 0,5 & 1,47 & 2,60 \\
\hline Bt1 & $80-110$ & 0 & $\mathrm{x}$ & 99 & 10 & 50 & 170 & 230 & 20 & 510 & 60 & 430 & 2 & 85 & 0,1 & 1,25 & 2,67 \\
\hline $\mathrm{Bt} 2$ & $110-150$ & 0 & 1 & 99 & 10 & 40 & 140 & 240 & 30 & 460 & 90 & 450 & 2 & 96 & 0,2 & 1,22 & 2,63 \\
\hline $\mathrm{Bt} 3$ & $150-180 / 190$ & 0 & 1 & 99 & 10 & 40 & 160 & 260 & 40 & 510 & 80 & 410 & 2 & 95 & 0,2 & 1,24 & 2,70 \\
\hline $\mathrm{Cr}$ & $180 / 190-200$ & 0 & 1 & 99 & 10 & 11 & 290 & 340 & 50 & 800 & 40 & 160 & 2 & 88 & 0,2 & $=$ & - \\
\hline
\end{tabular}

ATRIBUTOS QUIMICOS, DO PERFIL N ${ }^{\circ} 22$

\begin{tabular}{|c|c|c|c|c|c|c|c|c|c|c|c|c|c|c|c|}
\hline \multicolumn{2}{|c|}{ Horiz e/ou cam. } & \multicolumn{2}{|c|}{ PH. } & \multicolumn{6}{|c|}{ Complexo sortivo $(\mathrm{mmol} / \mathrm{Kg})$} & \multirow{2}{*}{$\frac{\text { Valor }}{S}$} & \multirow{2}{*}{$\frac{\text { Valor }}{\mathrm{T}}$} & \multirow[t]{2}{*}{$\mathrm{V} \%$} & \multirow[t]{2}{*}{$\mathrm{m} \%$} & \multirow{2}{*}{\multicolumn{2}{|c|}{$\begin{array}{c}\mathrm{P} \quad \mathrm{C} \text { org } \\
\mathrm{mg} / \mathrm{kg} \mathrm{g} \cdot \mathrm{kg}^{-1}\end{array}$}} \\
\hline Tipo & Prof. $\mathrm{cm}$ & $\mathrm{H}_{2} \mathrm{O}$ & $\mathrm{KCl}$ & $\mathrm{Ca}^{2+}$ & $\mathrm{Mg}^{2+}$ & $\mathrm{K}^{+}$ & $\mathrm{Na}^{+}$ & $\mathrm{Al}^{3+}$ & $\mathrm{H}^{+}$ & & & & & & \\
\hline$\overline{A p}$ & $0-20$ & 5,6 & 4,6 & 51 & 6 & 6,3 & 0,02 & 0 & 20 & 63,32 & 83,32 & 76 & 0 & 18 & 5,2 \\
\hline A2 & $20-50$ & 5,5 & 4,4 & 20 & 3 & 1,2 & 0,02 & 1 & 23 & 24,22 & 48,22 & 50 & 4 & 5 & 11,6 \\
\hline$A B$ & $50-80$ & 5,9 & 4,5 & 33 & 4 & 2,2 & 0,02 & 0 & 25 & 39,22 & 64,22 & 61 & 0 & 6 & 5,8 \\
\hline Bt1 & $80-110$ & 5,1 & 3,7 & 21 & 5 & 1,4 & 0,02 & 10 & 36 & 27,42 & 73,42 & 37 & 27 & 4 & 4,6 \\
\hline $\mathrm{Bt} 2$ & $110-150$ & 4,8 & 3,4 & 16 & 8 & 1,4 & 0,02 & 15 & 32 & 25,42 & 72,42 & 35 & 37 & 6 & 4,6 \\
\hline $\mathrm{Bt} 3$ & $150-180 / 190$ & 4,7 & 3,4 & 12 & 8 & 1,0 & 0,02 & 14 & 29 & 21,02 & 64,02 & 33 & 40 & 4 & 5,8 \\
\hline $\mathrm{Cr}$ & $180 / 190-200$ & 4,6 & 3,4 & 7 & 4 & 0,5 & 0,02 & 10 & 19 & 11,52 & 40,52 & 28 & 46 & 4 & 2,8 \\
\hline
\end{tabular}

ATRIBUTOS MINERALOGICOS DO PERFIL N ${ }^{\circ} 22$

\begin{tabular}{|c|c|c|c|c|c|c|c|c|c|c|c|c|}
\hline \multicolumn{2}{|c|}{ Horizonte (cam) } & \multicolumn{5}{|c|}{ ataque com $\mathrm{H}_{2} \mathrm{SO}_{4}$} & \multicolumn{2}{|c|}{ Relaçōes } & \multicolumn{2}{|c|}{$\%$ da $\mathrm{AF}$} & \multicolumn{2}{|c|}{ DRX } \\
\hline Tipo & Prof. (cm) & $\mathrm{SiO}_{2}$ & $\mathrm{Al}_{2} \mathrm{O}_{3}$ & $\mathrm{Fe}_{2} \mathrm{O}_{3}$ & $\mathrm{TiO}_{2}$ & $\mathrm{MnO}$ & $\mathrm{Ki}$ & $\mathrm{Kr}$ & Leves & Pesados & argila & silte \\
\hline Ap & $0-20$ & 3,43 & 3,09 & 1,01 & 0,47 & 0,04 & 1,89 & 1,56 & - & - & - & - \\
\hline Bt 1 & $20-110$ & 14,85 & 11,58 & 1,81 & 0,92 & 0,01 & 2,18 & 1,98 & 99,5 & 0,5 & $\mathrm{C}, \mathrm{Mi}, \mathrm{V}$ & $P, Q$ \\
\hline Bt3 & $150-180 / 190$ & 10,30 & 4,74 & 0,97 & 0,78 & 0,01 & 3,69 & 3,27 & 99,5 & 0,5 & - & - \\
\hline $\mathrm{Cr}$ & $200+$ & 5,75 & 8,70 & 1,77 & 0,52 & 0,01 & 1,12 & 0,99 & 99,5 & 0,5 & $\mathrm{C}, \mathrm{Mi}$ & $\mathrm{P}, \mathrm{Q}$ \\
\hline
\end{tabular}

COMPOSIÇÃO QUÍMICA ELEMENTAL DA FRAÇÃO AREIA FINA DO PERFIL 22

\begin{tabular}{|c|c|c|c|c|c|c|c|c|c|c|c|}
\hline Horiz/cam & & & IN & FLUORE & ESCÊNC & IA DE R & $\mathrm{AIO} X$ & & & & $\mathrm{Zr}$ \\
\hline & $\mathrm{SiO}_{2}$ & $\mathrm{Al}_{2} \mathrm{O}_{3}$ & $\mathrm{Fe}_{2} \mathrm{O}_{3}$ & $\mathrm{TiO}_{2}$ & $\mathrm{MnO}$ & $\mathrm{CaO}$ & $\mathrm{MgO}$ & $\mathrm{K}_{2} \mathrm{O}$ & $\mathrm{Na}_{2} \mathrm{O}$ & $\mathrm{P}_{2} \mathrm{O}_{5}$ & ppm \\
\hline Ap & 98,8324 & 0,4100 & 0,3041 & 0,0944 & 0,0016 & 0,0172 & 0,0000 & 0,0174 & 0,0202 & 0,0134 & 162 \\
\hline A2 & 98,4614 & 0,4538 & 0,3061 & 0,1229 & 0,0081 & 0,0302 & 0,0000 & 0,0131 & 0,0261 & 0,0102 & 215 \\
\hline$A B$ & 98,6120 & 0,4513 & 0,3136 & 0,0982 & 0,0062 & 0,0201 & 0,0000 & 0,0180 & 0,0216 & 0,0093 & 66 \\
\hline Bt1 & 98,5310 & 0,5447 & 0,3102 & 0,0995 & 0,0187 & 0,0362 & 0,0078 & 0,0211 & 0,0212 & 0,0126 & 132 \\
\hline $\mathrm{Bt} 2$ & 98,8946 & 0,4491 & 0,3299 & 0,0968 & 0,0058 & 0,0165 & 0,0000 & 0,0165 & 0,0238 & 0,0175 & 146 \\
\hline $\mathrm{Bt} 3$ & 98,5864 & 0,4613 & 0,4754 & 0,1017 & 0,0024 & 0,0172 & 0,0000 & 0,0184 & 0,0295 & 0,0401 & 125 \\
\hline $\mathrm{Cr}$ & 98,9633 & 0,4110 & 0,2395 & 0,0874 & 0,0019 & 0,0161 & 0,0000 & 0,0224 & 0,0226 & 0,0274 & 35 \\
\hline
\end{tabular}




\section{A. DESCRIĊ̃̃O GERAL}

PERFIL: $\mathrm{N}^{\circ} 30$

CLASSIFICACCÃO: Podzólico Vermelho Amarelo distrófico Tb A moderado textura média/argilosa, fase floresta subtropical subperennifolia, substrato arenito, relevo plano.

LOCALIZACCÃO: $150 \mathrm{~m}$ a Oeste do caminho e da casa do Prof. Miguel Rojas.

COORD. UTM: E0516125/N7118000 UN PEDOGEOMÓRFICA: 2a

RELEVO LOCAL: plano

ALTITUDE: 365 m.s.n.m.

RELEVO REGIONAL: ondulado a forte ondulado

DECLIVE: $2 \%$

DIREĊ̃̃: Norte

LITOLOGIA: Arenito arcosiano

POSIC̈̃̃O TOP: topo

COMPRIMENTO: $200 \mathrm{~m}$

FORMAC̄̃O GEOL.: "Cerro hũ"

ROCHOSIDADE: nula

PROF. DO LENCOL: $>2 \mathrm{~m}$

INUNDACÕES: nula

MAT. PARENTAL: saprolito de arenito arcosiano.

PEDREGOSIDADE: nula

DRENAGEM: bem drenado

EROSÃO: laminar ligeira

VEGET.PRIMÁRIA: Floresta subtropical subperennifolia

PRODUTIVIDADE: media

DESCRITO POR: Sérgio M. Burgos Sosa

USO ATUAL: pastorejo

CLIMA: temperado chuvoso (cfa)

\section{B. DESCRIÇÃO MORFOLÓGICA}

Ap 0-10 cm, bruno avermelhado escuro (5 YR 3/3, úmido), bruno avermelhado (5 YR 4/4, seco); franco-arenosa; moderado pequena a média granular e blocos subangulares ligeiramente duro, friável, ligeiramente plástico e ligeiramente pegajoso; transição gradual e plana.

A2 10-40 cm; bruno avermelhado escuro (5 YR 3/4, úmido), bruno avermelhado (5 YR 4/4, seco); franca argila-arenosa; moderado média blocos subangulares; duro, friável, plástico e pegajoso; transição difusa e plana.

A3 40-70 cm; bruno avermelhado escuro (5 YR 3/4, úmido), vermelho amarelado (5 YR 4/6, seco); franco argilo-arenosa; moderado média blocos subangulares; duro, friável, plástico e pegajoso; transição gradual e plana.

$\mathrm{AB}$ 70-90 cm; vermelho escuro (2.5 YR 3/6, úmido); vermelho (2.5 YR 4/6, seco), franco argiloarenoso; moderado media blocos subangulares; duro, friável, plástico e pegajoso; transição gradual e plana.

Bt1 90-110 cm; vermelho escuro (2.5 YR 3/6, úmido); vermelho (2.5 YR 4/6, seco); argilaoarenosa; moderado média e grande blocos subangulares: cerosidade fraca e pouca em poros e superfícies de agregados; muito duro, friável, plástico e pegajoso; transição difusa e plana.

Bt2 110-160 cm; vermelho escuro (2.5 YR 3/6, úmido), vermelho (2.5 YR 4/6, seco), argilo-arenosa; fraca grande e muito grande blocos subangulares; cerosidade moderado, comum, em poros e superfícies de agregados; muito duro, friável, plástico e pegajoso; transição difusa e plana.

Bt3 160-180 cm; vermelho escuro (2.5 YR 3/6, úmido), vermelho (2.5 YR 4/8, seco), argila arenosa; fraca grande a muito grande blocos subangulares; cerosidade fraca, comum em poros $\mathrm{e}$ superfícies de agregados; duro, friável, plástico e pegajoso; transição gradual e plana.

BC 180-210 cm: vermelho escuro (2.5 YR 3/6, úmido), vermelho (2.5 YR 4/8, seco); argila arenosa; moderado média a grande blocos subangulares, cerosidade fraca e pouca em poros; duro e friável, ligeiramente plástico e pegajoso, transição abrupta e descontínua.

Cc 210-230 cm: vermelho escuro (2.5 YR 3/6, úmido), vermelho (2.5 YR 4/8, seco), franco argiloarenosa; fraca muito pequena blocos subangulares; macio, friável. ligeiramente plástico $\mathrm{e}$ ligeiramente pegajoso; transição abrupta e irregular.

$\mathrm{Cr} 230 \mathrm{~cm} \mathrm{+;} \mathrm{rosado} \mathrm{(5} \mathrm{YR} \mathrm{7/4.} \mathrm{úmido),} \mathrm{rosado} \mathrm{(5} \mathrm{YR} \mathrm{8/4,} \mathrm{seco);} \mathrm{areia;} \mathrm{maciço,} \mathrm{muito} \mathrm{duro,}$ friável, não plástico e não pegajoso, rocha de contato lítico.

RAIZES: abundantes e muito finas no Ap e A2, comuns e muito finas no A3, poucas e muito finas no $A B, B t 1$ e $B t 2$, raras e muito finas no $B t 3$.

OBSERVAÇÕES: poucas raras concresões de ferro em todo o perfil, pequenas, duras e irregulares de cor bruno escuro. passando para frequentes na camada Cc. 
ATRIBUTOS FÍSICOS DO PERFIL N ${ }^{\circ} 30$

Horizontes calhau casca- terra Composição granulométrica $(\mathrm{g} / \mathrm{kg}) \quad$ Argila Grau relaç. Densidade e/ou camadas lho fina AMG AG AM AF AMF Areia Silte Argila disp a floc silte/ $\mathrm{Kg} / \mathrm{dm}^{3}$

\begin{tabular}{|c|c|c|c|c|c|c|c|c|c|c|c|c|c|c|c|c|c|}
\hline \multicolumn{8}{|c|}{ Tipo prof. $\mathrm{Cm}$} & \multicolumn{5}{|c|}{ Total } & \multirow[t]{2}{*}{$\%$} & \multirow{2}{*}{$\frac{\%}{50}$} & \multirow{2}{*}{$\begin{array}{c}\text { Argila } \\
0,6\end{array}$} & \multirow{2}{*}{$\frac{\text { Ds }}{1,52}$} & \multirow{2}{*}{$\frac{\mathrm{Dp}}{2,50}$} \\
\hline $\mathrm{Ap}$ & $0-10$ & 0 & $x$ & 99 & 0 & 50 & 310 & 340 & 40 & 740 & 100 & 160 & & & & & \\
\hline A2 & $10-40$ & 0 & $\mathrm{x}$ & 99 & 0 & 40 & 270 & 330 & 30 & 670 & 90 & 240 & 16 & 33 & 0,4 & 1,42 & 2,44 \\
\hline A3 & $40-70$ & 0 & $\mathrm{x}$ & 99 & 10 & 30 & 190 & 330 & 10 & 570 & 100 & 330 & 6 & 82 & 0,3 & - & - \\
\hline $\mathrm{AB}$ & $70-90$ & 0 & 1 & 99 & 0 & 30 & 190 & 320 & 30 & 570 & 80 & 350 & 2 & 94 & 0,2 & 1,21 & 2,50 \\
\hline Bt1 & $90-110$ & 0 & $\mathrm{x}$ & 99 & 10 & 20 & 190 & 280 & 30 & 530 & 100 & 370 & 2 & 95 & 0,3 & - & - \\
\hline Bt2 & $110-160$ & 0 & $\mathrm{x}$ & 99 & 0 & 20 & 180 & 240 & 30 & 470 & 60 & 470 & 2 & 96 & 0,1 & 1,09 & 2,50 \\
\hline $\mathrm{Bt} 3$ & $160-180$ & 0 & $\mathrm{x}$ & 99 & 0 & 20 & 140 & 270 & 60 & 490 & 60 & 450 & 2 & 96 & 0,1 & - & - \\
\hline $\mathrm{BC}$ & $180-210$ & 0 & 2 & 98 & 10 & 20 & 230 & 240 & 10 & 510 & 80 & 410 & 2 & 95 & 0,2 & 1,23 & 2,50 \\
\hline $\mathrm{Cc}$ & $210-230$ & 0 & 29 & 71 & 40 & 40 & 180 & 270 & 40 & 570 & 80 & 350 & 2 & 94 & 0,2 & & \\
\hline $\mathrm{Cr}$ & $230+$ & 0 & 0 & 100 & 0 & 40 & 690 & 200 & 10 & 940 & 20 & 40 & 2 & 50 & 0,5 & & \\
\hline
\end{tabular}

ATRIBUTOS QUIMICOS, DO PERFIL N ${ }^{\circ} 30$

\begin{tabular}{|c|c|c|c|c|c|c|c|c|c|c|c|c|c|c|c|}
\hline \multicolumn{2}{|c|}{ Horiz e/ou cam. } & \multicolumn{2}{|c|}{ PH. } & \multicolumn{6}{|c|}{ Complexo sortivo $(\mathrm{mmol} / \mathrm{Kg})$} & \multirow{2}{*}{$\begin{array}{c}\text { Valor } \\
\mathrm{S}\end{array}$} & \multirow{2}{*}{$\begin{array}{c}\text { Valor } \\
\mathrm{T}\end{array}$} & \multirow[t]{2}{*}{$\mathrm{V} \%$} & \multirow[t]{2}{*}{$\mathrm{m} \%$} & \multirow{2}{*}{$\begin{array}{c}\mathrm{P} \\
\mathrm{mg} / \mathrm{kg}\end{array}$} & \multirow{2}{*}{ C org } \\
\hline Tipo & Prof. $\mathrm{cm}$ & $\mathrm{H}, \mathrm{O}$ & $\mathrm{KCl}$ & $\mathrm{Ca}^{2+}$ & $\mathrm{Mg}^{2+}$ & $\mathrm{K}^{+}$ & $\mathrm{Na}^{+}$ & $\mathrm{Al}^{3+}$ & $\mathrm{H}^{+}$ & & & & & & \\
\hline Ap & $0-10$ & 6.5 & 4.2 & 15 & 7 & 1,0 & 0,2 & 2 & 106 & 23,2 & 131,2 & 18 & 8 & 3 & 9,8 \\
\hline A2 & $10-40$ & 5.4 & 3.8 & 17 & 4 & 0,3 & 0,2 & 6 & 152 & 21,5 & 179,5 & 12 & 22 & 2 & 9,8 \\
\hline A3 & $40-70$ & 6.0 & 4.0 & 25 & 5 & 0,6 & 0,2 & 6 & 112 & 30,8 & 148,8 & 21 & 16 & 2 & 8,7 \\
\hline $\mathrm{AB}$ & $70-90$ & 5.3 & 3.7 & 16 & 4 & 0,5 & 0,2 & 7 & 85 & 20,7 & 112,7 & 18 & 25 & 2 & 9,8 \\
\hline Bt 1 & $90-110$ & 5.9 & 3.8 & 19 & 4 & 0,6 & 0,2 & 6 & 101 & 23,8 & 130,8 & 18 & 20 & 2 & 5,7 \\
\hline $\mathrm{Bt} 2$ & $110-160$ & 5.5 & 3.8 & 21 & 5 & 0,8 & 0,2 & 6 & 82 & 27,0 & 115,0 & 23 & 18 & 4 & 8,7 \\
\hline $\mathrm{Bt} 3$ & $160-180$ & 5.5 & 3.9 & 16 & 5 & 0,6 & 0,2 & 6 & 95 & 21,8 & 122,8 & 18 & 22 & 3 & 5,7 \\
\hline $\mathrm{BC}$ & $180-210$ & 5.9 & 3.9 & 12 & 4 & 0,5 & 0,2 & 6 & 86 & 16,7 & 108,7 & 15 & 26 & 3 & 7,5 \\
\hline $\mathrm{Cc}$ & $210-230$ & 5.8 & 3.8 & 13 & 4 & 0,5 & 0,3 & 6 & 64 & 17,8 & 87,8 & 20 & 25 & 3 & 5,7 \\
\hline $\mathrm{Cr}$ & $230+$ & 5.5 & 4.0 & 5 & 2 & 0,4 & 0,2 & 5 & 137 & 7,6 & 149,6 & 5 & 40 & 1 & 5,7 \\
\hline
\end{tabular}

ATRIBUTOS MINERALOGICOS DO PERFIL N ${ }^{\circ} 30$

\begin{tabular}{cccccccccccccc}
\hline \multicolumn{1}{c}{ Horizonte (cam) } & \multicolumn{1}{c}{ ataque com $\mathrm{H}_{2} \mathrm{SO}_{4}$} & \multicolumn{3}{c}{ Relaçōes } & \multicolumn{2}{c}{ \% da AF } & \multicolumn{3}{c}{ DRX } \\
\hline Tipo & Prof. (cm) & $\mathrm{SiO}_{2}$ & \multicolumn{2}{c}{$\mathrm{Al}_{2} \mathrm{O}_{3}$} & $\mathrm{Fe}_{2} \mathrm{O}_{3}$ & $\mathrm{TiO}_{2}$ & $\mathrm{Mn} \mathrm{O}$ & $\mathrm{Ki}$ & $\mathrm{Kr}$ & Leves & Pesados & argila & silte \\
\hline $\mathrm{Ap}$ & $0-10$ & 5,45 & 3,81 & 0,99 & 0,55 & 0,02 & 2,43 & 2,09 & - & - & - & - \\
$\mathrm{Bt} 2$ & $110-160$ & 10,20 & 12,61 & 1,70 & 0,95 & 0,01 & 1,38 & 1,27 & 99,5 & 0,5 & $\mathrm{C}, \mathrm{V}, \mathrm{Mi}$ & $\mathrm{P}, \mathrm{Q}$ \\
$\mathrm{BC}$ & $180-210$ & 12,12 & 11,33 & 1,56 & 0,97 & 0,01 & 1,82 & 1,67 & 99,0 & 1,0 & $\mathrm{C}, \mathrm{V}, \mathrm{Mi}$ & $\mathrm{P}, \mathrm{Q}$ \\
$\mathrm{Cc}$ & $210-230$ & 12,32 & 11,58 & 3,25 & 1,12 & 0,01 & 1,81 & 1,53 & 95,0 & 5,0 & $\mathrm{C}, \mathrm{V}, \mathrm{Mi}$ & $\mathrm{P}, \mathrm{Q}$ \\
$\mathrm{Cr}$ & $230+$ & 1,82 & 2,11 & 0,19 & 0,13 & 0,01 & 1,46 & 1,39 & 99,0 & 1,0 & $\mathrm{C}, \mathrm{Mi}$ & $\mathrm{P}, \mathrm{Q}$ \\
\hline
\end{tabular}

COMPOSIÇÃO QUÍMICA ELEMENTAL DA FRAÇÃO AREIA FINA DO PERFIL 30

\begin{tabular}{cccccccccccc}
\hline Horiz/cam & \multicolumn{8}{c}{ INFLUORESCENCIA DE RAIO X (\%) } & \multicolumn{1}{c}{ Zr } \\
\hline & $\mathrm{SiO}_{2}$ & $\mathrm{Al}_{2} \mathrm{O}_{3}$ & $\mathrm{Fe}_{2} \mathrm{O}_{3}$ & $\mathrm{TiO}_{2}$ & $\mathrm{MnO}$ & $\mathrm{CaO}$ & $\mathrm{MgO}$ & $\mathrm{K}_{2} \mathrm{O}$ & $\mathrm{Na}_{2} \mathrm{O}$ & $\mathrm{P}_{2} \mathrm{O}_{5}$ & $\mathrm{ppm}$ \\
\hline $\mathrm{Ap}$ & 98,5387 & 0,4808 & 0,4953 & 0,1032 & 0,0050 & 0,0180 & 0,0000 & 0,0184 & 0,0151 & 0,0085 & 98 \\
$\mathrm{~A} 2$ & 98,3214 & 0,5736 & 0,5018 & 0,1012 & 0,0072 & 0,0212 & 0,0000 & 0,0241 & 0,0304 & 0,0097 & 85 \\
$\mathrm{~A} 3$ & 98,6970 & 0,4890 & 0,4942 & 0,1113 & 0,0038 & 0,0217 & 0,0000 & 0,0204 & 0,0291 & 0,0105 & 143 \\
$\mathrm{AB}$ & 97,5295 & 0,4924 & 0,4840 & 0,1000 & 0,0024 & 0,0174 & 0,0000 & 0,0196 & 0,0097 & 0,0083 & 94 \\
$\mathrm{Bt1}$ & 98,6621 & 0,5847 & 0,5152 & 0,1011 & 0,0021 & 0,0245 & 0,0000 & 0,0284 & 0,0448 & 0,0103 & 61 \\
$\mathrm{Bt} 2$ & 98,0690 & 0,7503 & 0,5378 & 0,1139 & 0,0018 & 0,0447 & 0,0397 & 0,0349 & 0,0463 & 0,0151 & 210 \\
$\mathrm{Bt3}$ & 98,3289 & 0,5285 & 0,5586 & 0,0877 & 0,0015 & 0,0220 & 0,0000 & 0,0200 & 0,0148 & 0,0101 & - \\
$\mathrm{BC}$ & 98,3373 & 0,5548 & 0,5549 & 0,1230 & 0,0014 & 0,0200 & 0,0000 & 0,0205 & 0,0237 & 0,0072 & 192 \\
$\mathrm{Cc}$ & 95,8803 & 0,9505 & 1,9416 & 0,1108 & 0,0026 & 0,0176 & 0,0000 & 0,0266 & 0,0494 & 0,0265 & 114 \\
$\mathrm{Cr}$ & 93,7380 & 0,5148 & 0,4346 & 0,0885 & 0,0015 & 0,0224 & 0,0000 & 0,0168 & 0,0409 & 0,0083 & - \\
\hline
\end{tabular}


PERFIL: No 31

\section{A. DESCRIĊÃO GERAL}

CLASSIFICACCÃO: Cambissolo álico petroplíntico Ta A moderado textura media argilosa, fase floresta subtropical subperennifolia, substrato arenito, relevo ondulado.

LOCALIZACÃ̃O: $200 \mathrm{~m}$ ao leste do caminho e da casa do Prof. Miguel Rojas.

COORD. UTM: E0516650/N7118300 UN PEDOGEOMÓRFICA: 2b

RELEVO LOCAL: ondulado

ALTITUDE: 365 m.s.n.m.

DECLIVE: $6 \%$

DIREÇ̃̃O: leste

RELEVO REGIONAL: ondulado e forte ondulado

LITOLOGIA: Arenito arcosiano

POSIČÃO TOP: hombro

ROCHOSIDADE: nula

COMPRIMENTO: $100 \mathrm{~m}$

FORMAČ̃̃ GEOL.: "Cerro hũ"

PROF. DO LENCOL: $>2 \mathrm{~m}$

INUNDAC̄ÕES: nula

MAT. PARENTAL: saprólito de arenito arcosiano.

PEDREGOSIDADE: nula

EROSÃO: laminar moderado

DRENAGEM: moderadamente drenado

PRODUTIVIDADE: media

DESCRITO POR: Sérgio M. Burgos Sosa

VEGET.PRIMÁRIA: Floresta subtropical subperennifolia

USO ATUAL: pastoreio

CLIMA: temperado chuvoso (cfa)

\section{B. DESCRIČÃO MORFOLÓGICA}

Ap 0-12 cm, bruno avermelhado escuro (5 YR 3/4, úmido), bruno avermelhado (5 YR 4/4, seco); franco-arenosa; fraca pequena a media granular e blocos subangulares; ligeiramente duro, friável, ligeiramente plástico e ligeiramente pegajoso; transição abrupta e plana.

A2 12-53 cm; bruno avermelhado escuro (5 YR 3/4, úmido), bruno avermelhado (5 YR 4/4, seco); franco argilo-arenosa; moderado pequena a média granular e blocos subangulares; ligeiramente duro, friável, ligeiramente plástico e pegajoso; transição gradual e plana.

$\mathrm{AB} \quad 53-72 \mathrm{~cm}$; bruno avermelhado escuro (2.5 YR 3/4, úmido), vermelho (2.5 YR 4/6, seca); franco argilo-arenosa; moderado pequena e grande blocos subangulares; cerosidade fraca e pouca em poros; muito duro, friável, ligeiramente plástico e pegajoso; transição gradual e plana.

Bi 72-105/110 cm; bruno avermelhado escuro (2.5 YR 2.5/4, úmido); vermelho escuro (2.5 YR $3 / 6$, seco), argila arenosa; moderado pequena a média blocos subangulares; cerosidade fraca e pouca em poros e superfícies de agregados; muito duro, friável, ligeiramente plástico e pegajoso; transição abrupta e descontínuo.

F 105/110-140/150 cm; preto avermelhado (10 R 2.5/1, úmido); vermelho muito escuro e escuro acinzentado (10 R 2.5/2, seco); argila; maciço, extremamente duro, extremamente firme, plástico e pegajoso, transição abrupta e descontínua.

$\mathrm{Cr} 140 / 150 \mathrm{~cm} \mathrm{+;} \mathrm{vermelho} \mathrm{amarelado} \mathrm{(5} \mathrm{YR} \mathrm{5/8,} \mathrm{úmido),} \mathrm{amarelo} \mathrm{avermelhado} \mathrm{(5} \mathrm{YR} \mathrm{6/8,} \mathrm{seco)}$ mosqueado comum, pequeno de cor bruno avermelhado escuro (2.5 YR 3/4, úmido); francoarenosa, maciço, muito duro, friável, não plástico e não pegajoso. (rocha intemperizada).

RAIZES: abundantes e finas no $\mathrm{Ap}$, comuns e muito finas na $\mathrm{A} 2, \mathrm{Bt}$ e $\mathrm{Bt} 2$, raras e muito finas no $\mathrm{F}$.

OBSERVAÇÕES: poucas concresões de ferro, pequenas, duras, irregulares de cor bruno escuro nos horizontes Ap, A2, Bt1 e Bt2 passando para dominante na camada F. 
ATRIBUTOS FÍSICOS DO PERFIL N ${ }^{\circ} 31$

\begin{tabular}{|c|c|c|c|c|c|c|c|c|c|c|c|c|c|c|c|c|c|}
\hline & Horizontes & calh & casca- & terra & & ompos & ssição & Gran & nulom & netrica & $(\mathrm{g} / \mathrm{K}$ & & Argil & Grau & Relaç. & Dens & asidad \\
\hline & e/ou camadas & & lho & fina & AMG & AG & AM & $\mathrm{AF}$ & $\mathrm{AM}$ & Areia & Silte & Argila & $\operatorname{disp}$ & floc. & - Silte/ & & $\mathrm{g} / \mathrm{dm}^{3}$ \\
\hline Tipo & Prof. cm & & & & & & & & & Total & & & $\%$ & $\%$ & argila & Ds & $\mathrm{Dr}$ \\
\hline Ap & $0-12$ & 0 & $x$ & 99 & 0 & 50 & 340 & 370 & 40 & 800 & 20 & 180 & 8 & 56 & 0,1 & 1,58 & 82,67 \\
\hline $\mathrm{A} 2$ & $12-53$ & 0 & $x$ & 99 & 0 & 40 & 230 & 320 & 40 & 630 & 130 & 240 & 10 & 58 & 0,5 & 1,29 & 92,63 \\
\hline $\mathrm{AB}$ & $53-72$ & 0 & 5 & 95 & 10 & 30 & 190 & 310 & 10 & 550 & 120 & 330 & 6 & 82 & 0,4 & 1,36 & 62,70 \\
\hline $\mathrm{Bi}$ & $72-105 / 110$ & 0 & 6 & 94 & 0 & 30 & 180 & 270 & 30 & 510 & 120 & 370 & 2 & 95 & 0,3 & 1,33 & 2,63 \\
\hline $\mathrm{F}$ & $105 / 110-140 / 150$ & 0 & 39 & 61 & 50 & 40 & 120 & 200 & 30 & 440 & 40 & 520 & 2 & 96 & 0,1 & - & - \\
\hline $\mathrm{Cr}$ & $40 / 150-180$ & 0 & 12 & 88 & 0 & 80 & 320 & 340 & 30 & 770 & 30 & 200 & 5 & 75 & 0,1 & - & - \\
\hline
\end{tabular}

ATRIBUTOS QUIMICOS, DO PERFIL Nº 31

\begin{tabular}{|c|c|c|c|c|c|c|c|c|c|c|c|c|c|c|c|}
\hline \multicolumn{2}{|c|}{ Horiz e/ou cam. } & \multicolumn{2}{|c|}{$\mathrm{PH}$. } & \multicolumn{6}{|c|}{ Complexo sortivo (mmol/Kg) } & \multirow{2}{*}{$\begin{array}{c}\text { Valor } \\
S\end{array}$} & \multirow{2}{*}{$\begin{array}{c}\text { Valor } \\
\mathrm{T}\end{array}$} & \multirow{2}{*}{$\mathrm{V} \%$} & \multirow[t]{2}{*}{$\mathrm{m} \%$} & \multirow{2}{*}{$\frac{\mathrm{P}}{\mathrm{mg} / \mathrm{kg}}$} & \multirow{2}{*}{$\begin{array}{l}\text { C org. } \\
\mathrm{g} \cdot \mathrm{kg}^{-1}\end{array}$} \\
\hline Tipo & Prof. cm & $\mathrm{H}_{2} \mathrm{O}$ & $\mathrm{KCl}$ & $\mathrm{Ca}^{2+}$ & $\mathrm{Mg}^{2+}$ & $\mathrm{K}^{+}$ & $\mathrm{Na}^{+}$ & $\mathrm{Al}^{3+}$ & $\mathrm{H}^{+}$ & & & & & & \\
\hline Ap & $0-12$ & 5.6 & 4.1 & 11 & 6 & 0,8 & 0,2 & 4 & 134 & 18,0 & 156,0 & 12 & 18 & 4 & 13,8 \\
\hline A2 & $12-53$ & 5.2 & 3.7 & 11 & 3 & 0,5 & 0,2 & 11 & 107 & 14,7 & 132,7 & 11 & 43 & 2 & 11,5 \\
\hline $\mathrm{AB}$ & $53-72$ & 5.3 & 3.7 & 14 & 3 & 0,8 & 0,2 & 18 & 192 & 18,0 & 228,0 & 8 & 50 & 3 & 9,8 \\
\hline $\mathrm{Bi}$ & $72-105 / 110$ & 5.1 & 3.6 & 13 & 3 & 0,6 & 0,2 & 13 & 157 & 16,8 & 186,8 & 9 & 44 & 4 & 9,8 \\
\hline $\mathrm{F}$ & $105 / 110-140 / 150$ & 5.5 & 3.7 & 13 & 4 & 0,9 & 0,2 & 15 & 103 & 18,1 & 226,1 & 8 & 45 & 3 & 7,5 \\
\hline $\mathrm{Cr}$ & $40 / 150-180$ & 5.2 & 3.8 & 6 & 2 & 0,8 & 0,3 & 8 & 125 & 9,1 & 142,1 & 6 & 47 & 3 & 8,6 \\
\hline
\end{tabular}

ATRIBUTOS MINERALOGICOS DO PERFIL N ${ }^{\circ} 31$

\begin{tabular}{|c|c|c|c|c|c|c|c|c|c|c|c|}
\hline \multicolumn{2}{|c|}{ Horizonte (cam) } & \multicolumn{5}{|c|}{ atague com $\mathrm{H}_{2} \mathrm{SO}_{4}$} & Relações & \multicolumn{2}{|c|}{$\%$ da AF } & \multicolumn{2}{|c|}{ DRX } \\
\hline Tipo & Prof. $(\mathrm{cm})$ & $\mathrm{SiO}_{2}$ & $\mathrm{Al}_{2} \mathrm{O}_{3}$ & $\mathrm{Fe}_{2} \mathrm{O}_{3}$ & $\mathrm{TiO}_{2}$ & $\mathrm{MnO}$ & $\mathrm{Ki} \quad \mathrm{Kr}$ & Leves & Pesados & argila & Silte \\
\hline $\mathrm{Ap}$ & $0-12$ & 5,00 & 3,11 & 1,07 & 0,34 & 0,04 & $1,961,57$ & 99,5 & 0,5 & - & - \\
\hline $\mathrm{Bi}$ & $72-105 / 110$ & 10,6 & 9,22 & 1,74 & 0,91 & 0,01 & $1,951,74$ & 99,5 & 0,5 & $\mathrm{C}, \mathrm{Mo}, \mathrm{Mi}$ & $P, Q$ \\
\hline $\mathrm{F}$ & $105 / 110-140 / 150$ & 17,17 & 14,21 & 6,44 & 4,29 & 0,01 & $2,051,61$ & 95,5 & 4,5 & $\mathrm{C}, \mathrm{V}, \mathrm{Mi}$ & $P, Q$ \\
\hline $\mathrm{Cr}$ & $140 / 150-180$ & 6,87 & 5,00 & 1,74 & 0,49 & 0,01 & $2,331,91$ & 99,5 & 0,5 & $\mathrm{C}, \mathrm{V}, \mathrm{Mi}$ & $P, Q$ \\
\hline
\end{tabular}

COMPOSIÇÃO QUÍMICA ELEMENTAL DA FRAÇÃO AREIA FINA DO PERFIL 31

\begin{tabular}{|c|c|c|c|c|c|c|c|c|c|c|c|}
\hline Horiz/cam & & & INI & LUORE & CÊNCIA & DE RAI & $5 \times(\%)$ & & & & $\mathrm{Zr}$ \\
\hline & $\mathrm{SiO}_{2}$ & $\mathrm{Al}, \mathrm{O}_{3}$ & $\mathrm{Fe}, \mathrm{O}_{3}$ & $\mathrm{TiO}_{2}$ & $\mathrm{MnO}$ & $\mathrm{CaO}$ & $\mathrm{MgO}$ & $\mathrm{K}_{2} \mathrm{O}$ & $\mathrm{Na}_{2} \mathrm{O}$ & $\mathrm{P}_{2} \mathrm{O}_{5}$ & $\mathrm{ppm}$ \\
\hline Ap & 98,4119 & 0,5331 & 0,5261 & 0,1061 & 0,0051 & 0,0210 & 0,0000 & 0,0178 & 0,0202 & 0,0095 & 86 \\
\hline$A 2$ & 98,1923 & 0,5358 & 0,5391 & 0,1087 & 0,0074 & 0,0217 & 0,0000 & 0,0226 & 0,0168 & 0,0086 & 100 \\
\hline Bt 1 & 98,4857 & 4809 & 0,5618 & 0,1089 & 0,0035 & 0,0221 & 0,0000 & 0,0172 & 0,0308 & 0,0099 & 133 \\
\hline Bt2 & 95,4822 & & 0,4361 & 0,0855 & 0,0015 & 0,0165 & 0,0000 & 0,0151 & 0,0201 & 0,0081 & 112 \\
\hline $\mathrm{F}$ & 95,5328 & & 2,2699 & 0,1262 & 0,0013 & 0,0209 & 0,0000 & 0,0273 & 0,0436 & 0,0238 & 125 \\
\hline $\mathrm{Cr}$ & 98,2715 & 0,5494 & 0,6392 & 0,0617 & 0,0007 & 0,0203 & 0,0000 & 0,0171 & 0,0185 & 0,0124 & 171 \\
\hline
\end{tabular}


PERFIL: $\mathrm{N}^{\circ} 32$

\section{A. DESCRIĊÃO GERAL}

CLASSIFICAÇĀO: Cambissolo álico petroplíntico Ta A moderado textura media, fase floresta subtropical subperennifolia, substrato arenito, relevo ondulado.

LOCALIZACCÃO: $300 \mathrm{~m}$ ao leste do caminho e da casa do Prof. Miguel Rojas.

COORD. UTM: E0516850/N7118400 UN PEDOGEOMÓRFICA: 2b

RELEVO LOCAL: ondulado

ALTITUDE: 350 m.s.n.m.

DECLIVE: $7 \%$

DIREÇÃO: leste

RELEVO REGIONAL: ondulado e forte ondulado

POSIČÃO TOP: hombro

LITOLOGIA: Arenito arcosiano

COMPRIMENTO: $100 \mathrm{~m}$

ROCHOSIDADE: nula

FORMAČ̃̃O GEOL.: "Cerro hũ"

PROF. DO LENCOL: $>2 \mathrm{~m}$

INUNDACÕES: nula

MAT. PARENTAL: saprólito de arenito arcosiano.

PEDREGOSIDADE: nula

EROSÃO: laminar forte

DRENAGEM: moderadamente drenado

PRODUTIVIDADE: baixa

DESCRITO POR: Sérgio M. Burgos Sosa

VEGET. PRIMÁRIA: Floresta subtropical subperennifolia

USO ATUAL: pastil

CLIMA: temperado chuvoso (cfa)

\section{B. DESCRIĊÃO MORFOLÓGICA}

Ap 0-6 cm, bruno avermelhado escuro (5 YR 3/4, úmido), bruno avermelhado (5 YR 4/4, seco); franco-arenosa; moderado pequena e média granular e blocos subangulares; ligeiramente duro, friável, ligeiramente plástico e ligeiramente pegajoso; transição abrupta e ondulada.

A2 6-25 cm; bruno avermelhado escuro (5 YR 3/4, úmido), bruno avermelhado (5 YR 4/4, seco); franco argilo-arenosa; moderado pequena a media blocos subangulares; ligeiramente duro, friável, ligeiramente plástico e ligeiramente pegajoso; transição gradual e plana.

Bi 25-48/52 cm; bruno avermelhado escuro (2.5 YR 2.5/4, úmido), vermelho escuro (2.5 Y R 5/6, seco); franco argila-arenosa; moderado media a grande blocos subangulares; cerosidade fraca $\mathrm{e}$ pouca em poros e superfície de agregados; duro, friável, plástico e pegajoso; transição abrupta e ondulada.

F 48/52-65/70 cm; vermelho escuro (10 R 3/6, úmido); vermelho (70 R 4/6, seco), franco argiloarenosa; maciço, extremamente duro, extremamente firme; transição clara e ondulada.

$\mathrm{Cr} \quad$ 65-70 cm +; vermelho amarelado (5 YR 5/8 úmido), amarelo avermelhado (5 YR 6/8, seco) franco-arenosa; maciço, extremamente duro, firme, não plástico e não pegajoso.

RAIZES: comuns e finas no Ap, abundantes, finas a grossas no A2 e B, poucas e muito finas no Fmc, sem raízes no $R$.

OBSERVAÇÕES: poucas concresões de ferro cimentadas, pequenas e grandes, irregulares e duras de cor bruno escuro no horizonte Bi passando para dominante na camada $\mathrm{F}$. 
ATRIBUTOS FÍSICOS DO PERFIL N ${ }^{\circ} 32$

\begin{tabular}{|c|c|c|c|c|c|c|c|c|c|c|c|c|c|c|c|c|c|}
\hline \multirow{2}{*}{\multicolumn{2}{|c|}{$\begin{array}{l}\text { Horizontes } \\
\text { e/ou camadas }\end{array}$}} & \multicolumn{3}{|c|}{ calhau casca- terra } & \multicolumn{8}{|c|}{ COMPOSIÇÃO GRANULOMETRICA g/Kg } & \multirow{2}{*}{\multicolumn{3}{|c|}{ Argila Grau Relaç. }} & \multirow{2}{*}{\multicolumn{2}{|c|}{$\begin{array}{c}\text { Densidade } \\
\mathrm{Kg} / \mathrm{dm}^{3}\end{array}$}} \\
\hline & & & lho & fina & AMG & AG & $\mathrm{AM}$ & $\mathrm{AF}$ & AMF & Areia & & & disp & & & & \\
\hline Tipo & Prof. $\mathrm{Cm}$ & & & & & & & & & Total & & & $\%$ & $\%$ & argila & & \\
\hline Ap & & 0 & 1 & & & 40 & 240 & & & 710 & 90 & 200 & & 60 & 0,4 & 1,43 & \\
\hline $\mathrm{A} 2$ & & & & & & & 220 & & & & & 24 & & & & 1,40 & 2 , \\
\hline $\mathrm{Bi}$ & & & & & 2 & & 180 & & & & & 330 & & & & 1,30 & 2,50 \\
\hline $\mathrm{F}$ & $48 / 5$ & & 45 & & $y$ & & 220 & & & & & 310 & & & & seras & - \\
\hline $\mathrm{Cr}$ & $65 / 70+$ & 0 & 4 & 96 & 40 & 140 & 190 & 370 & 60 & 800 & 60 & 140 & 0 & 57 & 0,4 & & \\
\hline
\end{tabular}

ATRIBUTOS QUIMICOS, DO PERFIL No 32

\begin{tabular}{|c|c|c|c|c|c|c|c|c|c|c|c|c|c|c|c|}
\hline \multicolumn{2}{|c|}{ Horiz e/ou cam. } & \multicolumn{2}{|c|}{$\mathrm{PH}$. } & \multicolumn{6}{|c|}{ Complexo sortivo $(\mathrm{mmol} / \mathrm{Kg})$} & \multirow{2}{*}{$\frac{\text { Valor }}{S}$} & \multirow{2}{*}{$\frac{\text { Valor }}{\mathrm{T}}$} & \multirow[t]{2}{*}{$\mathrm{V} \%$} & \multirow[t]{2}{*}{$\mathrm{m} \%$} & \multirow{2}{*}{\multicolumn{2}{|c|}{$\begin{array}{c}\mathrm{P} \quad \mathrm{C} \text { org. } \\
\mathrm{mg} / \mathrm{kg} \mathrm{g} \cdot \mathrm{kg}^{-1}\end{array}$}} \\
\hline Tipo & Prof. $\mathrm{cm}$ & $\mathrm{H}_{2} \mathrm{O}$ & $\mathrm{KCl}$ & $\mathrm{Ca}^{2+}$ & $\mathrm{Mg}^{2+}$ & $\mathrm{K}^{+}$ & $\mathrm{Na}^{+}$ & $\mathrm{Al}^{3+}$ & $\mathrm{H}^{+}$ & & & & & & \\
\hline Ap & $0-6$ & 5.6 & 4.5 & 19 & 7 & 1,0 & 0,3 & 3 & 109 & 27,3 & 139,3 & 20 & 10 & 5 & 12,7 \\
\hline A2 & $6-25$ & 5.0 & 3.7 & 10 & 3 & 0,4 & 0,2 & 14 & 140 & 13,6 & 167,6 & 8 & 51 & 3 & 11,6 \\
\hline $\mathrm{Bi}$ & $25-48 / 52$ & 5.2 & 3.7 & 7 & 1 & 0,3 & 0,2 & 20 & 130 & 8,5 & 158,5 & 5 & 70 & 2 & 12,7 \\
\hline $\mathrm{F}$ & $48 / 52-65 / 70$ & 5.2 & 3.7 & 9 & 3 & 0,5 & 1,0 & 16 & 174 & 13,5 & 203,5 & 7 & 54 & 4 & 8,7 \\
\hline $\mathrm{Cr}$ & $65 / 70+$ & 5.5 & 4.0 & 6 & 2 & 0,2 & 0,2 & 6 & 94 & 8,4 & 108,4 & 8 & 42 & 1 & 13,8 \\
\hline
\end{tabular}

ATRIBUTOS MINERALOGICOS DO PERFIL N 32

\begin{tabular}{|c|c|c|c|c|c|c|c|c|c|c|c|c|}
\hline \multicolumn{2}{|c|}{ Horizonte (cam) } & \multicolumn{5}{|c|}{ ataque $\operatorname{com~H} \mathrm{H}_{2} \mathrm{SO}_{4}$} & \multicolumn{2}{|c|}{ Relaçōes } & \multicolumn{2}{|c|}{$\% \mathrm{da} A \mathrm{~F}$} & \multicolumn{2}{|c|}{ DRX } \\
\hline Tipo & Prof. (cm) & $\mathrm{SiO}_{2}$ & $\overline{\mathrm{Al}_{2} \mathrm{O}_{3}}$ & $\overline{\mathrm{Fe}_{2} \mathrm{O}_{3}}$ & $\mathrm{TiO}_{2}$ & Mn O & $\mathrm{Ki}$ & $\mathrm{Kr}$ & Leves & $\begin{array}{c}\text { Pesado } \\
\text { s }\end{array}$ & argila & Silte \\
\hline Ap & $0-6$ & 5,80 & 4,13 & 1,95 & 0,50 & 0,03 & 2,39 & 1,83 & 99,5 & 0,5 & $\mathrm{C}, \mathrm{V}, \mathrm{Mi}$ & $\mathrm{P}, \mathrm{Q}$ \\
\hline $\mathrm{Bi}$ & $25-48 / 52$ & 11,31 & 8,96 & 1,99 & 0,96 & 0,02 & 2,15 & 1,88 & 99,0 & 1,0 & $\mathrm{C}, \mathrm{V}, \mathrm{Mo}, \mathrm{Mi}$ & $P, Q$ \\
\hline $\mathrm{F}$ & $48 / 52-65 / 70$ & 12,32 & 10,50 & 4,12 & 1,15 & 0,01 & 1,99 & 1,59 & 97,0 & 3,0 & $\mathrm{C}, \mathrm{V}, \mathrm{Mi}$ & $P, Q$ \\
\hline $\mathrm{Cr}$ & $65 / 70+$ & 4,24 & 4,43 & 2,04 & 0,51 & 0,01 & 1,63 & 1,26 & - & - & - & - \\
\hline
\end{tabular}

COMPOSIÇÃO QUÍMICA ELEMENTAL DA FRAÇÃO AREIA FINA DO PERFIL 32

\begin{tabular}{ccccccccccccc}
\hline Horiz/cam & \multicolumn{8}{c}{ INFLUORESCENCIA DE RAIO X (\%) } & \multicolumn{2}{c}{$\mathrm{Zr}$} \\
\hline & $\mathrm{SiO}_{2}$ & $\mathrm{Al}_{2} \mathrm{O}_{3}$ & $\mathrm{Fe}_{2} \mathrm{O}_{3}$ & $\mathrm{TiO}_{2}$ & $\mathrm{MnO}$ & $\mathrm{CaO}$ & $\mathrm{MgO}$ & $\mathrm{K}_{2} \mathrm{O}$ & $\mathrm{Na}_{2} \mathrm{O}$ & $\mathrm{P}_{2} \mathrm{O}_{5}$ & $\mathrm{ppm}$ \\
\hline $\mathrm{Ap}$ & 98,1162 & 0,6157 & 0,6181 & 0,1160 & 0,0059 & 0,0266 & 0,0000 & 0,0219 & 0,0218 & 0,0119 & 186 \\
$\mathrm{~A} 2$ & 97,9793 & 0,6161 & 0,5967 & 0,1125 & 0,0067 & 0,0260 & 0,0008 & 0,0232 & 0,0394 & 0,0116 & 119 \\
$\mathrm{Bi}$ & 98,4695 & 0,5433 & 0,5944 & 0,1081 & 0,0041 & 0,0188 & 0,0000 & 0,0204 & 0,0303 & 0,0110 & 110 \\
$\mathrm{~F}$ & 90,5083 & 3,5191 & 3,9912 & 0,1921 & 0,0122 & 0,0387 & 0,0000 & 0,0575 & 0,0436 & 0,0238 & 163 \\
$\mathrm{Cr}$ & 96,2768 & 1,4782 & 2,0597 & 0.0424 & 0,0036 & 0,0221 & 0,0000 & 0,0173 & 0,0419 & 0,0180 & 38 \\
\hline
\end{tabular}




\section{A. DESCRIĊ̃̃O GERAL}

PERFIL: $\mathrm{N}^{\circ} 34$

CLASSIFICAĊÃO: Cambissolo álico Ta A moderado textura media, fase floresta subtropical subperennifolia, substrato arenito, relevo ondulado.

LOCALIZAC̄ÃO: $500 \mathrm{~m}$ ao leste do caminho e da casa do Prof. Miguel Rojas.

COORD. UTM: E0517300/N7118700 UN PEDOGEOMÓRFICA: 2b

RELEVO LOCAL: ondulado

RELEVO REGIONAL: ondulado e forte ondulado

ALTITUDE: 290 m.s.n.m.

POSIĊÃO TOP: encosta media

DECLIVE: $7 \%$

COMPRIMENTO: $100 \mathrm{~m}$

DIREÇÃO: leste

FORMACÃO GEOL.: "Cerro hũ"

LITOLOGIA: Arenito arcosiano

MAT. PARENTAL: saprólito de arenito arcosiano.

ROCHOSIDADE: forte

PEDREGOSIDADE: nula

PROF. DO LENCOL: $>2 \mathrm{~m}$

DRENAGEM: bem drenado

INUNDACÕES: nula

VEGET. PRIMÁRIA: Floresta subtropical subperennifolia

EROSÃO: laminar forte

USO ATUAL: pastoreio

PRODUTIVIDADE: baixa

CLIMA: temperado chuvoso (cfa)

DESCRITO POR: Sérgio M. Burgos Sosa

\section{B. DESCRICCÃO MORFOLÓGICA}

A 0-10/12 cm, bruno escuro (7.5 YR 3/2, úmido), bruno (7.5 YR 5/3, seco); franco-arenosa; fraca pequena e média granular e blocos subangulares; macio, friável, não plástico e não pegajoso; transição gradual e ondulada.

Bi 10/12-40/50 cm; bruno escuro (7.5 YR 4/4, úmido), bruno (7.5 YR 5/4, seco); franco-arenosa; fraca media a grande blocos subangulares; cerosidade fraca e pouca em superfície dos grãos e inter-grãos; ligeiramente duro, friável, ligeiramente plástico e ligeiramente pegajoso; transição abrupta e irregular.

Cr 40-50 cm +; cinzento claro (10 YR 7/2, úmido), branco (10 YR 8/1, seco); areia; maciço, extremamente duro, extremamente firme, contato lítico.

RAIZES: abundantes, muito finas e medias no A, poucas e muito finas no C;

OBSERVAÇÕES: poucas concresōes de ferro, pequenas duras, irregulares de cor bruno escuro em todo o perfil. 
ATRIBUTOS FÍSICOS DO PERFIL N ${ }^{\circ} 34$

\begin{tabular}{|c|c|c|c|c|c|c|c|c|c|c|c|c|c|c|c|c|}
\hline \multirow{2}{*}{\multicolumn{2}{|c|}{$\begin{array}{l}\text { Horizontes } \\
\text { e/ou camadas }\end{array}$}} & \multicolumn{3}{|c|}{ calhau casca- terra } & \multicolumn{8}{|c|}{ COMPOSIÇÃO GRANULOMETRICA g/Kg } & \multicolumn{3}{|c|}{ Argila Grau Relaç. } & \multirow{3}{*}{$\begin{array}{l}\text { Densidade } \\
\mathrm{Kg} / \mathrm{dm}^{3}\end{array}$} \\
\hline & & & & fina & AMG & $A G$ & AM & $\mathrm{AF}$ & AMF & Areia & Silte & Argila & a Disp & floc. & Silte/ & \\
\hline Tipo & Prof. cm & & & & & & & & & Total & & & $\%$ & $\%$ & argila & \\
\hline $\mathrm{A}$ & $0-10 / 12$ & 0 & 2 & 98 & 10 & 50 & 230 & 420 & 50 & 760 & 60 & 180 & 4 & 78 & 0,3 & $1,36 \quad 2,63$ \\
\hline $\mathrm{Bi}$ & $10 / 12-40 / 50$ & 0 & 1 & 99 & 10 & 70 & 280 & 370 & 30 & 760 & 80 & 160 & 10 & 38 & 0,5 & $1,37 \quad 2,53$ \\
\hline $\mathrm{Cr}$ & $40 / 50+$ & 0 & 5 & 95 & 40 & 300 & 390 & 180 & 30 & 940 & 20 & 40 & 2 & 50 & 0,5 & $-\quad-$ \\
\hline
\end{tabular}

ATRIBUTOS QUIMICOS, DO PERFIL N ${ }^{\circ} 34$

\begin{tabular}{|c|c|c|c|c|c|c|c|c|c|c|c|c|c|c|c|}
\hline Hor & $z$ e/ou cam. & $\mathrm{PH}$ & & & Comple & $\mathrm{xosc}$ & tivo ( & $\mathrm{mol} / \mathrm{K}$ & & Valor & Valor & V\% & $\mathrm{m} \%$ & $\mathrm{P}$ & C org. \\
\hline Tipo & Prof. cm & $\mathrm{H}_{2} \mathrm{O}$ & $\mathrm{KCl}$ & $\mathrm{Ca}^{2+}$ & $\mathrm{Mg}^{2+}$ & $\mathrm{K}^{+}$ & $\mathrm{Na}^{+}$ & $\mathrm{Al}^{3+}$ & $\mathrm{H}^{+}$ & $S$ & $\mathrm{~T}$ & & & $\mathrm{mg} / \mathrm{k}$ & g. $\mathbf{k g}^{-1}$ \\
\hline $\mathrm{A}$ & $0-10 / 12$ & 4.2 & 4.7 & 4 & 1 & 0,8 & 0,2 & 10 & 230 & 6,0 & 246,0 & 2 & 63 & 7 & $1 \overline{7}, 9$ \\
\hline $\mathrm{Bi}$ & $10 / 12-40 / 50$ & 4.7 & 3.8 & 4 & 1 & 0,3 & 0,2 & 19 & 91 & 5,5 & 115,5 & 5 & 78 & 3 & 8,7 \\
\hline $\mathrm{Cr}$ & $40 / 50+$ & 4.8 & 4.0 & 2 & 1 & 0,2 & 0,2 & 3 & 67 & 3,4 & 73,4 & 5 & 47 & 2 & 5,8 \\
\hline
\end{tabular}

ATRIBUTOS MINERALOGICOS DO PERFIL No 34

\begin{tabular}{|c|c|c|c|c|c|c|c|c|c|c|c|c|}
\hline \multicolumn{2}{|c|}{ Horizonte (cam) } & \multicolumn{5}{|c|}{ ataque $\operatorname{com} \underline{\mathrm{H}}_{2} \mathrm{SO}_{4}$} & \multicolumn{2}{|c|}{ Relaçōes } & \multicolumn{2}{|c|}{$\% \mathrm{da} \mathrm{AF}$} & \multicolumn{2}{|c|}{ DRX } \\
\hline Tipo & Prof. $(\mathrm{cm})$ & $\mathrm{SiO}_{2}$ & $\mathrm{Al}_{2} \mathrm{O}_{3}$ & $\overline{\mathrm{FeO}_{3}}$ & $\mathrm{TiO}_{2}$ & $\mathrm{Mn} \mathrm{O}$ & $\mathrm{Ki}$ & $\mathrm{Kr}$ & Leves & Pesados & argila & silte \\
\hline $\mathrm{A}$ & $0-10 / 12$ & 4,40 & 3,62 & 1,30 & 0,33 & 0,01 & 2,07 & 1,68 & 99,5 & 0,5 & - & - \\
\hline $\mathrm{Bi}$ & $10 / 12-40 / 50$ & 5,86 & 4,22 & 0,73 & 0,43 & 0,01 & 2,36 & 2,12 & 99,5 & 0,5 & $\mathrm{C}, \mathrm{V}, \mathrm{Mi}$ & $P, Q$ \\
\hline $\mathrm{Cr}$ & $40 / 50+$ & 1,92 & 1,08 & 0,37 & 0,12 & 0,01 & 2,02 & 2,47 & 99,5 & 0,5 & $\mathrm{C}, \mathrm{Mi}$ & $\mathrm{P}, \mathrm{Q}$ \\
\hline
\end{tabular}

COMPOSIÇÃO QUÍMICA ELEMENTAL DA FRAÇÃO AREIA FINA DO PERFIL 34

\begin{tabular}{|c|c|c|c|c|c|c|c|c|c|c|c|}
\hline Horiz/cam & & & & IFLUOR & SCÊNCI & $\mathrm{ADE} \mathrm{RA}$ & $\mathrm{OX}(\%)$ & & & & $\mathrm{Zr}$ \\
\hline & $\mathrm{SiO}_{2}$ & $\mathrm{Al}_{2} \mathrm{O}_{3}$ & $\mathrm{Fe}_{2} \mathrm{O}_{3}$ & $\mathrm{TiO}_{2}$ & $\mathrm{MnO}$ & $\mathrm{CaO}$ & $\mathrm{MgO}$ & $\mathrm{K}_{2} \mathrm{O}$ & $\mathrm{Na}_{2} \mathrm{O}$ & $\mathrm{P}_{2} \mathrm{O}_{5}$ & $\mathrm{ppm}$ \\
\hline $\mathrm{A}$ & $\overline{98,3918}$ & 0,5711 & 0,5010 & 0,1047 & 0,0071 & 0,0232 & 0,0000 & 0,0256 & 0,0360 & 0,0106 & 92 \\
\hline $\mathrm{Bt}$ & 98,2788 & 0,5875 & 0,4910 & 0,1021 & 0,0031 & 0,0212 & 0,0000 & 0,0371 & 0,0260 & 0,0087 & 145 \\
\hline $\mathrm{Cr}$ & 97,6214 & 1,1054 & 0,5563 & 0,0663 & 0,0019 & 0,0213 & 0,0000 & 0,0562 & 0,0320 & 0,0119 & 56 \\
\hline
\end{tabular}


PERFIL: $\mathrm{N}^{\circ} 35$

\section{A. DESCRIČÃO GERAL}

CLASSIFICAČÃO: Cambissolo álico petroplíntico Ta A proeminente textura media, fase floresta subtropical subperennifolia, substrato arenito, relevo ondulado.

LOCALIZACCÃO: $600 \mathrm{~m}$ ao leste do caminho e da casa do Prof. Miguel Rojás.

COORD. UTM: E0517450/N7118800 UN PEDOGEOMÓRFICA: 2b

RELEVO LOCAL: ondulado

ALTITUDE: 245 m.s.n.m.

DECLIVE: $9 \%$

DIRECÃO: leste

LITOLOGIA: Arenito arcosiano

RELEVO REGIONAL: ondulado a forte ondulado

POSIČ̃̃O TOP: encosta media

COMPRIMENTO: $300 \mathrm{~m}$

FORMAĊ̃̃ GEOL.: "Cerro hũ"

ROCHOSIDADE: forte

MAT. PARENTAL: saprólito de arenito arcosiano.

PROF. DO LENCOL: $>2 \mathrm{~m}$

PEDREGOSIDADE: nula

INUNDACÕES: nula

EROSÃO: laminar forte

DRENAGEM: moderadamente drenado

VEGET. PRIMÁRIA: Floresta subtropical subperennifolia

USO ATUAL: pastoreio

PRODUTIVIDADE: baixa

CLIMA: temperado chuvoso (cfa)

DESCRITO POR: Sérgio M. Burgos Sosa

\section{B. DESCRIČÃO MORFOLÓGICA}

A $\quad 0-18 / 20 \mathrm{~cm}$, bruno escuro (7.5 YR 3/3, úmido), bruno (10 YR 5/3, seco); franco-arenosa; fraca muito pequena a pequena granular; macio, friável, não plástico e não pegajoso; transição gradual e ondulada.

$\mathrm{AB}$ 18/20-40 cm; bruno escuro (7.5 YR 3/4, úmido), bruno amarelado (7.5 YR 5/4, seco); francoarenosa; fraca media blocos subangulares; cerosidade fraca e pouca em poros e inter-grãos; ligeiramente duro, friável, ligeiramente plástico e ligeiramente pegajoso; transição difusa e plana.

$\mathrm{Bi} \quad 40-70 / 75 \mathrm{~cm}$; bruno escuro (7.5 YR 3/4, úmido), bruno amarelado (10 YR 5/4, seco); francoarenosa; moderado media a grande blocos subangulares; cerosidade fraca e pouca em poros e inter-grãos; ligeiramente duro, friável, ligeiramente plástico e ligeiramente pegajoso; transição abrupta e descontínua.

Cc 70/75-80/85 cm; bruno escuro (7.5 YR 3/4, úmido), bruno amarelado (10 YR 5/4, seco); franco argilo-arenosa; maciço, por partes e extremamente duro, extremamente firme, ligeiramente plástico e ligeiramente pegajoso transição abrupta e ondulada.

$\mathrm{Cr} 80 / 85 \mathrm{~cm} \mathrm{+}$; cinzento claro (10 YR 7/2, úmido), branco (10 YR 8/1, seco); areia; extremamente duro, extremamente firme, transição abrupta e ondulada.

RAIZES: abundantes e muito finas no $\mathrm{A}$, comuns e muito fina no $\mathrm{Bt} 1$; poucas e muito finas no $\mathrm{Bt}$, raras e muito tinas no Cc.

OBSERVAÇÕES: poucas concresões de ferro, pequenas, duras, irregulares de cor bruno escuro em todo o perfil, passando para dominante na camada Cc. 
ATRIBUTOS FÍSICOS DO PERFIL N ${ }^{\circ} 35$

\begin{tabular}{|c|c|c|c|c|c|c|c|c|c|c|c|c|c|c|c|c|c|}
\hline \multirow{2}{*}{\multicolumn{2}{|c|}{$\begin{array}{l}\text { Horizontes } \\
\text { e/ou camadas }\end{array}$}} & \multicolumn{3}{|c|}{ calhau casca- terra } & \multicolumn{8}{|c|}{ COMPOSIÇÃO GRANULOMETRICA g/Kg } & \multicolumn{5}{|c|}{ Argila Grau Relaç. Densidad } \\
\hline & & & & & & $A G$ & AM & $\mathrm{AF}$ & & & & & & & & $\mathrm{Kg} /$ & $/ \mathrm{dm}^{3}$ \\
\hline Cipo & Prof. cm & & & & & & & & & Total & & & $\%$ & $\%$ & Argila & a Ds & Dr \\
\hline A & & & & & & & & & & & & & & & 0,2 & 1,47 & 72,67 \\
\hline $\mathrm{AB}$ & & & tra & & & 30 & 310 & & & & & & & &, 3 & 1,39 & 2,6 \\
\hline $\mathrm{Bi}$ & & & 1 & & 10 & 0 & 40 & & 0 & & 100 & 200 & & & 0,5 & 1,46 & 52,70 \\
\hline Cc & $70 / 75$ & 2 & 6 & & 40 & 0 & 220 & & 40 & & 80 & 240 & & & 0,3 & - & - \\
\hline $\mathrm{Cr}$ & $80 / 85+$ & 1 & 2 & 97 & 40 & 320 & 380 & 180 & 0 & 920 & 20 & 60 & 4 & 33 & 0,3 & - & - \\
\hline
\end{tabular}

ATRIBUTOS QUIMICOS, DO PERFIL No 35

\begin{tabular}{|c|c|c|c|c|c|c|c|c|c|c|c|c|c|c|c|}
\hline \multicolumn{2}{|c|}{ Horiz e/ou cam. } & \multicolumn{2}{|c|}{ PH. } & \multicolumn{6}{|c|}{ Complexo sortivo (mmol/Kg) } & \multirow{2}{*}{$\frac{\text { Valor }}{S}$} & \multirow{2}{*}{$\frac{\text { Valor }}{\mathrm{T}}$} & \multirow[t]{2}{*}{ V\% } & \multirow[t]{2}{*}{$\mathrm{m} \%$} & \multirow{2}{*}{$\frac{\mathrm{P}}{\mathrm{mg} / \mathrm{kg}}$} & \multirow{2}{*}{$\frac{C \text { org. }}{\text { g. } \mathrm{kg}^{-1}}$} \\
\hline Tipo & Prof. cm & $\mathrm{H}_{2} \mathrm{O}$ & $\mathrm{KCl}$ & $\mathrm{a}^{2+}$ & $\mathrm{Mg}^{2+}$ & $\mathrm{K}^{+}$ & $\mathrm{Na}^{+}$ & $\mathrm{Al}^{3+}$ & $\mathrm{H}^{+}$ & & & & & & \\
\hline $\mathrm{A}$ & $0-18 / 20$ & 4.4 & 3.7 & 5 & 2 & 1,2 & 0,2 & 17 & 173 & 8,4 & 198,4 & 4 & 67 & 4 & 13,9 \\
\hline $\mathrm{AB}$ & $18 / 20-40$ & 4.4 & 3.6 & 5 & 2 & 0,5 & 0,2 & 20 & 128 & 7,7 & 155,7 & 5 & 72 & 2 & 7,5 \\
\hline $\mathrm{Bi}$ & $40-70 / 75$ & 4.2 & 3.6 & 3 & 1 & 0,5 & 0,2 & 20 & 100 & 4,7 & 124,7 & 4 & 81 & 2 & 9,8 \\
\hline Cc & $70 / 75-80 / 85$ & 4.6 & 3.7 & 3 & 1 & 0,7 & 0,2 & 24 & 156 & 4,9 & 184,9 & 3 & 83 & 2 & 9,8 \\
\hline $\mathrm{Cr}$ & $80 / 85+$ & 5.0 & 4.1 & 1 & 1 & 0,2 & 0,2 & 7 & 63 & 2,4 & 72,4 & 3 & 74 & 2 & 5,8 \\
\hline
\end{tabular}

ATRIBUTOS MINERALOGICOS DO PERFIL Nº 35

\begin{tabular}{|c|c|c|c|c|c|c|c|c|c|c|c|c|}
\hline \multicolumn{2}{|c|}{ Horizonte (cam) } & \multicolumn{5}{|c|}{ ataque $\operatorname{com~} \mathrm{H}_{2} \mathrm{SO}_{4}$} & \multicolumn{2}{|c|}{ Relaçōes } & \multicolumn{2}{|c|}{$\%$ da $\mathrm{AF}$} & \multicolumn{2}{|c|}{ DRX } \\
\hline Tipo & Prof. $(\mathrm{cm})$ & $\mathrm{SiO}_{2}$ & $\mathrm{Al}_{2} \mathrm{O}_{3}$ & $\mathrm{Fe}_{2} \mathrm{O}_{3}$ & $\mathrm{TiO}_{2}$ & $\mathrm{MnO}$ & $\mathrm{Ki}$ & $\mathrm{Kr}$ & Leves & Pesados & argila & Silte \\
\hline $\mathrm{A}$ & $0-18 / 20$ & 3,30 & 3,42 & 0,96 & 0,31 & 0,01 & 1,64 & 1,39 & 99,5 & 0,5 & - & - \\
\hline $\mathrm{Bi}$ & $40-70 / 75$ & 6,36 & 4,48 & 0,98 & 0,54 & 0,01 & 2,41 & 2,11 & 99,5 & 0,5 & $\mathrm{C}, \mathrm{V}$ & $P, Q$ \\
\hline $\mathrm{Cc}$ & $70 / 75-80 / 85$ & 6,77 & 5,50 & 0,83 & 0,52 & 0,01 & 2,09 & 1,91 & 99,5 & 0,5 & $\mathrm{C}, \mathrm{V}, \mathrm{Mi}$ & $P, Q$ \\
\hline $\mathrm{Cr}$ & $80 / 85+$ & - & - & - & - & - & - & - & 99,0 & 1,0 & $\mathrm{C}, \mathrm{V}, \mathrm{Mi}$ & $\mathrm{P}, \mathrm{Q}$ \\
\hline
\end{tabular}

COMPOSIÇÃO QUÍMICA ELEMENTAL DA FRAÇÃO AREIA FINA DO PERFIL 35

\begin{tabular}{|c|c|c|c|c|c|c|c|c|c|c|c|}
\hline Horiz/cam & & & & FLUORI & ESCÊNC & IA DE $R$ & AIO X & & & & $\mathrm{Zr}$ \\
\hline & $-\mathrm{SiO}_{2}$ & $-\mathrm{Al}_{2} \mathrm{O}_{3}$ & $\mathrm{Fe}_{2} \mathrm{O}_{3}$ & $\mathrm{TiO}_{2}$ & $\mathrm{MnO}$ & $\mathrm{CaO}$ & $\mathrm{MgO}$ & $\mathrm{K}_{2} \mathrm{O}$ & $\mathrm{Na}_{2} \mathrm{O}$ & $\mathrm{P}_{2} \mathrm{O}_{5}$ & ppm \\
\hline A & 98,3015 & 0,5733 & 0,4688 & 0,0967 & 0,0014 & 0,0234 & 0,0000 & 0,0331 & 0,0212 & 0,0119 & 100 \\
\hline Bt 1 & 98,3898 & 0,5803 & 0,4604 & 0,1090 & 0,0014 & 0,0234 & 0,0000 & 0,0346 & 0,0317 & 0,0106 & 124 \\
\hline Bt2 & 98,5833 & 0,5171 & 0,4497 & 0,1051 & 0,0141 & 0,0224 & 0,0000 & 0,0332 & 0,0252 & 0,0111 & 222 \\
\hline $\mathrm{Cc}$ & 98,5464 & 0,5400 & 0,4433 & 0,1102 & 0,0012 & 0,0200 & 0,0000 & 0,0357 & 0,0333 & 0,0121 & 221 \\
\hline $\mathrm{Cr}_{\mathrm{r}}$ & 97,9335 & 0,6964 & 0,4162 & 0,0971 & 0,0022 & 0,0264 & 0,0000 & 0,0389 & 0,0536 & 0,0164 & 50 \\
\hline
\end{tabular}




\section{A. DESCRIČ̃̃ GERAL}

PERFIL: N $^{\circ} 40$

CLASSIFICACẼ̃O: Regossolo distrófico Ta A moderado textura média, fase floresta subtropical subperennifolia, substrato arenito, relevo ondulado.

LOCALIZAČÃO: Cimeira do morro ao Leste do caminho na propriedade Sr. Ortiz.

COORD. UTM: E0513200/N7122850

RELEVO LOCAL: ondulado

ALTITUDE: 390 m.s.n.m.

DECLIVE: $1 \%$

DIRECCÃO: Oeste

LITOLOGIA: Arenito sacoroidal

ROCHOSIDADE: ligeira

PROF. DO LENCOL: $>2 \mathrm{~m}$

INUNDACÕES: nula

EROSÃO: laminar ligeira

PRODUTIVIDADE: baixa
UN PEDOGEOMÓRFICA: 3a

RELEVO REGIONAL: ondulado a forte ondulado

POSIĊÃO TOP: topo

COMPRIMENTO: $200 \mathrm{~m}$

FORMAČ̃̃O GEOL.: "Tovatî"

MAT. PARENTAL: saprolito de arenito sacoroidal

PEDREGOSIDADE: ligeira

DRENAGEM: acentuadamente drenado

VEG. PRIMÁRIA: Floresta subtropical subperennifolia

USO ATUAL: florestal

CLIMA: temperado chuvoso (cfa)

DESCRITO POR: Sérgio M. Burgos Sosa

\section{B. DESCRIĊÃO MORFOLÓGICA}

0 4-0 cm, folhas e galhos em processo de degradação serrapilheira, transição abrupta e irregular.

Al 0-3 cm; bruno escuro (7.5 YR 3/2, úmido), bruno escuro (7.5 YR 4/3, seco); franco-arenosa; grãos simples; macio, solto, não plástico e não pegajoso; transição abrupta e ondulada.

A2 3-14 cm; bruno escuro (7.5 YR 3/5, úmido), bruno (7.5 YR 5/3, seco); franco-arenosa; fraca muito pequena e média granular; macio, friável, não plástico e não pegajoso; transição gradual e plana.

C 14-36/50 cm; bruno escuro (7.5 YR 3/3, úmido); bruno (7.5 YR 5/3, seco), areia franca; fraca pequena e média granular e blocos subangulares; macio, friável, não plástico e não pegajoso; transição abrupta e irregular.

Cr 36/50 cm +; rosado (7.5 YR 7/4, úmido); rosado (7.5 YR 8/3, seco); areia, maciço, muito duro, friável, não plástico e não pegajoso; (rocha intemperizada).

RAIZES: abundantes, finas e muito finas no A1, comuns muito finas a médias no A2 e C.

OBSERVAÇÕES: poucas concresões de ferro, pequenas, duras e irregulares de cor bruno escuro e fragmentos de arenito intemperizado em todo o perfil. 
ATRIBUTOS FÍSICOS DO PERFIL N ${ }^{\circ} 40$

\begin{tabular}{|c|c|c|c|c|c|c|c|c|c|c|c|c|c|c|c|c|}
\hline \multirow{3}{*}{\multicolumn{2}{|c|}{$\begin{array}{l}\text { Horizontes } \\
\text { e/ou camadas } \\
\text { Tipo prof. Cm }\end{array}$}} & \multicolumn{4}{|c|}{ calhau casca- terra } & \multicolumn{7}{|c|}{ composição granulométrica $\mathrm{g} / \mathbf{k g}$} & \multirow{3}{*}{$\begin{array}{c}\text { Argila } \\
\text { disp a } \\
\% \\
\end{array}$} & \multirow{3}{*}{$\begin{array}{c}\text { Grau } \\
\text { floc } \\
\% \\
\end{array}$} & \multicolumn{2}{|c|}{$\begin{array}{c}\text { relaç. Densidad } \\
\text { e }\end{array}$} \\
\hline & & & lho & fina & AMG & AG & AM & $\mathrm{AF}$ & AMF & Areia & & & & & & $\mathrm{Kg} / \mathrm{dm}^{3}$ \\
\hline & & & & & & & & & & Total & & & & & argila & Ds $\mathrm{Dp}$ \\
\hline A1 & & & & & & & & & & & & & & & 0,3 & $1,532,53$ \\
\hline A2 & & & 1 & & & & 33 & & & & & & & & & $-\quad-$ \\
\hline $\mathrm{C}$ & & 0 & 2 & & 0 & 40 & 340 & & 40 & & 60 & & & &, 6 & $1,442,60$ \\
\hline $\mathrm{Cr}$ & $36-50$ & 0 & 1 & 99 & 0 & 20 & 660 & 250 & 10 & 940 & 20 & +40 & 2 & 50 & 0,5 & $-\quad-$ \\
\hline
\end{tabular}

ATRIBUTOS QUIMICOS, DO PERFIL N 40

\begin{tabular}{|c|c|c|c|c|c|c|c|c|c|c|c|c|c|c|c|}
\hline \multicolumn{2}{|c|}{ Horiz e/ou cam. } & \multicolumn{2}{|c|}{ PH. } & \multicolumn{6}{|c|}{ Complexo sortivo $(\mathrm{mmol} / \mathrm{Kg})$} & \multirow{2}{*}{$\frac{\text { Valor }}{S}$} & \multirow{2}{*}{$\begin{array}{c}\text { Valor } \\
\mathrm{T}\end{array}$} & \multirow[t]{2}{*}{$\mathrm{V} \%$} & \multirow[t]{2}{*}{$\mathrm{m} \%$} & \multirow{2}{*}{$\frac{\mathrm{P}}{\mathrm{mg} / \mathrm{kg}}$} & \multirow{2}{*}{ C org. } \\
\hline Tipo & Prof. $\mathrm{cm}$ & $\mathrm{H}_{2} \mathrm{O}$ & $\mathrm{KCl}$ & $\mathrm{Ca}^{2+}$ & $\mathrm{Mg}^{2+}$ & $\mathrm{K}^{+}$ & $\mathrm{Na}^{+}$ & $\mathrm{Al}^{3+}$ & $\mathrm{H}^{+}$ & & & & & & \\
\hline $\bar{A} 1$ & $0-3$ & 4.8 & 4.4 & 37 & 6 & 5,9 & 0,4 & 4 & 170 & 49,3 & 219,3 & 22 & 8 & 16 & 23,7 \\
\hline A2 & $3-14$ & 4.6 & 4.2 & 23 & 5 & 2,6 & 0,2 & 6 & 170 & 30,8 & 200,8 & 15 & 16 & 12 & 17,9 \\
\hline C & $14-36$ & 4.7 & 3.7 & 12 & 2 & 4,5 & 0,2 & 10 & 158 & 15,7 & 173,7 & 9 & 39 & 5 & 15,6 \\
\hline $\mathrm{Cr}$ & $36-50$ & 4.9 & 4.2 & 4 & 1 & 0,5 & 0,2 & 4 & 56 & 5,7 & 61,7 & 9 & 41 & 2 & 5,8 \\
\hline
\end{tabular}

ATRIBUTOS MINERALOGICOS DO PERFIL No 40

\begin{tabular}{|c|c|c|c|c|c|c|c|c|c|c|c|c|}
\hline \multicolumn{2}{|c|}{ Horizonte (cam) } & \multicolumn{5}{|c|}{ ataque com $\mathrm{H}_{2} \mathrm{SO}_{4}$} & \multicolumn{2}{|c|}{ Relações } & \multicolumn{2}{|c|}{$\%$ da $\mathrm{AF}$} & \multicolumn{2}{|c|}{ DRX } \\
\hline Tipo & Prof. $(\mathrm{cm})$ & $\mathrm{SiO}_{2}$ & $\overline{\mathrm{Al}}, \overline{\mathrm{O}_{3}}$ & $\mathrm{Fe}_{2} \mathrm{O}_{3}$ & $\mathrm{TiO}_{2}$ & $\mathrm{MnO}$ & $\mathrm{Ki}$ & $\mathrm{Kr}$ & Leves & Pesados & argila & Silte \\
\hline A1 & $0-3$ & 3,90 & 2,19 & 0,89 & 0,32 & 0,03 & 3,03 & 2,40 & 99,5 & 0,5 & - & - \\
\hline $\mathrm{C}$ & $14-36$ & 3,80 & 2,60 & 2,62 & 0,36 & 0,01 & 2,48 & 1,50 & 99,5 & 0,5 & $\mathrm{C}, \mathrm{Mi}, \mathrm{V}$ & $\mathrm{P}, \mathrm{Q}$ \\
\hline $\mathrm{Cr}$ & $36-50$ & 1,60 & 0,86 & 0,15 & 0,09 & 0,01 & 3,16 & 2,83 & 99,5 & 0,5 & $\mathrm{C}, \mathrm{Mi}$ & $\mathrm{P}, \mathrm{Q}$ \\
\hline
\end{tabular}

COMPOSIÇÃO QUÍMICA ELEMENTAL DA FRAÇÃO AREIA FINA DO PERFIL 40

\begin{tabular}{cccccccccccc}
\hline Horiz/cam & \multicolumn{8}{c}{ INFLUORESCENCIA DE RAIO X $(\%)$} & \multicolumn{2}{c}{ Zr } \\
\hline & $\mathrm{SiO}_{2}$ & $\mathrm{Al}_{2} \mathrm{O}_{3}$ & $\mathrm{Fe}_{2} \mathrm{O}_{3}$ & $\mathrm{TiO}_{2}$ & $\mathrm{MnO}$ & $\mathrm{CaO}$ & $\mathrm{MgO}$ & $\mathrm{K}_{2} \mathrm{O}$ & $\mathrm{Na}_{2} \mathrm{O}$ & $\mathrm{P}_{2} \mathrm{O}_{5}$ & $\mathrm{ppm}$ \\
\hline $\mathrm{A} 1$ & 97,0608 & 0,8575 & 0,4822 & 0,1108 & 0,0096 & 0,0368 & 0,0000 & 0,0608 & 0,0332 & 0,0184 & 176 \\
$\mathrm{~A} 2$ & 97,9475 & 0,8646 & 0,4923 & 0,1163 & 0,0104 & 0,0281 & 0,0000 & 0,0643 & 0,0225 & 0,0167 & 136 \\
$\mathrm{C}$ & 97,7332 & 0,8429 & 0,4764 & 0,1068 & 0,0075 & 0,0240 & 0,0000 & 0,0578 & 0,0197 & 0,0148 & 69 \\
$\mathrm{Cr}$ & 98,2743 & 0,5090 & 0,1080 & 0,0613 & 0,0024 & 0,0218 & 0,0000 & 0,0517 & 0,0223 & 0,0083 & 16 \\
\hline
\end{tabular}




\section{A. DESCRICẼ̃O GERAL}

PERFIL: $\mathrm{N}^{\circ} 41$

CLASSIFICACCÃO: Podzólico Vermelho Amarelo álico plíntico $\mathrm{Tb} A$ prominente textura arenosa/media, fase floresta subtropical subperennifolia, substrato arenito, relevo forte ondulado.

LOCALIZACCÃO: $200 \mathrm{~m}$ ao leste do caminho na propriedade do Sr. Ortiz.

COORD. UTM: E0512825/N7122900

RELEVO LOCAL: forte ondulado

ALTITUDE: 325 m.s.n.m.

DECLIVE: $8 \%$

DIRECẼ̃: oeste

LITOLOGIA: Arenito sacoroidal

ROCHOSIDADE: nula

PROF. DO LENCOL: $2 \mathrm{~m}$

INUNDACÕES: nula

EROSÃO: laminar ligeira

PRODUTIVIDADE: baixa
UN PEDOGEOMÓRFICA: 3c

RELEVO REGIONAL: ondulado a forte ondulado

POSIĊÃO TOP: encosta superior

COMPRIMENTO: $50 \mathrm{~m}$

FORMAČ̃̃O GEOL.: "Tovati"”

MAT. PARENTAL: saprólito de arenito sacoroidal.

PEDREGOSIDADE: nula

DRENAGEM: moderadamente drenado

VEGET. PRIMÁRIA: Floresta subtropical subperennifolia

USO ATUAL: pastoreio

CLIMA: temperado chuvoso (cfa)

DESCRITO POR: Sérgio M. Burgos Sosa

\section{B. DESCRIČ̃̃O MORFOLÓGICA}

Ap 0-10 cm, bruno escuro (7.5 YR 3/3, úmido), bruno (7.5 YR 5/3, seco); areia franca; fraca muito pequena a media granular; macio, friável, não plástico e não pegajoso; transição difusa e plana.

A2 10-70 cm; bruno escuro (7.5 YR 3/3, úmido), bruno (7.5 YR 5/3, seco); areia franca; fraca muito pequena a media granular, macio, friável; não plástico e não pegajoso; transição dif. e plana.

A3 70-130/140 cm; bruno escuro (7.5 YR 3/3, úmid•), bruno claro (7.5 YR 6/3, seco); areia franca; grãos simples; macio, friável, não plástico e não pegajoso; transição gradual e ondulada.

E 130/140-170/180 cm; bruno (7.5 YR 5/4, úmido), rosado (7.5 YR 7/4, seco); areia; grão simples; macio, friável, não plástico e não pegajoso; transição gradual e descontínua.

E/B 170/180 cm +; bruno (7.5 YR 5/4, úmido), rosado (7.5 YR 7/4, seco); mosqueados comuns médio resaltantes de cor vermelho (2.5 YR 4/6, úmido); areia franca; grãos simples; fraca pequena blocos subangulares; ligeiramente duro, friável, não plástico e não pegajoso, transição gradual e ondulada.

RAIZES: abundantes finas e grossas no Ap, comuns e fïnas no A2; poucas e muito finas no A3, raras e muito finas no $E$, poucas e muito finas no E/B. Poucas concressões de ferro pequenas duras e irregulares de cor bruno escuro nos horizontes A3, E. E/B e Bt.

OBSERVAÇÕES: - a transição do E/B para o $B$ não foi possivel determinar por causa da presença do lençol freático a $2 \mathrm{~m}$ de profundidade. 
ATRIBUTOS FÍSICOS DO PERFIL No 41

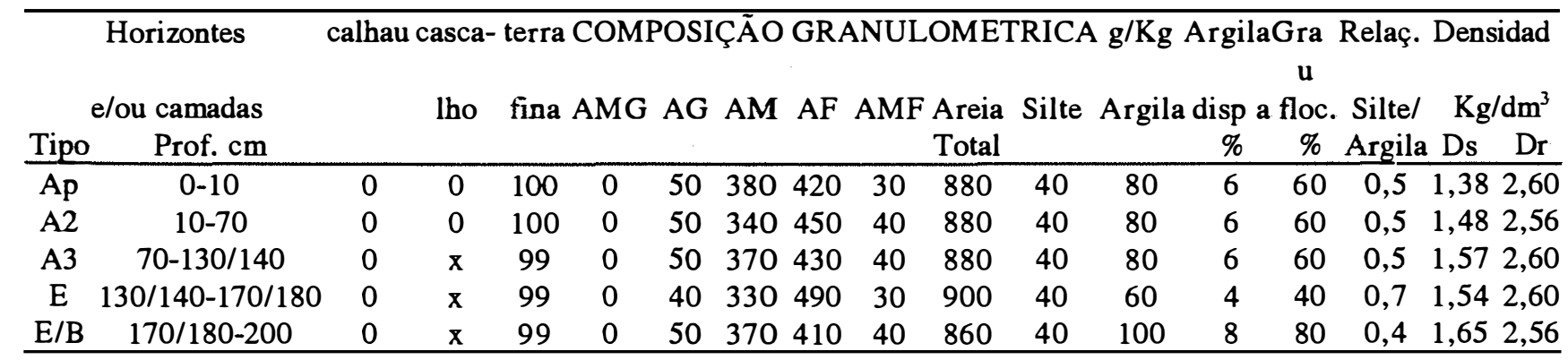

ATRIBUTOS QUIMICOS, DO PERFIL N ${ }^{\circ} 41$

\begin{tabular}{|c|c|c|c|c|c|c|c|c|c|c|c|c|c|c|c|}
\hline \multicolumn{2}{|c|}{ Horiz e/ou cam. } & \multicolumn{2}{|c|}{ PH. } & \multicolumn{6}{|c|}{ Complexo sortivo $(\mathrm{mmol} / \mathrm{Kg})$} & \multirow{2}{*}{$\frac{\text { Valor }}{S}$} & \multirow{2}{*}{$\frac{\text { Valor }}{\mathrm{T}}$} & \multirow[t]{2}{*}{$\mathrm{V} \%$} & \multirow[t]{2}{*}{$\mathrm{m} \%$} & \multirow{2}{*}{$\frac{\mathrm{P}}{\mathrm{mg} / \mathrm{kg}}$} & \multirow{2}{*}{$\frac{\mathrm{C} \text { org }}{\mathrm{g} \cdot \mathrm{kg}^{-1}}$} \\
\hline Tipo & Prof. $\mathrm{cm}$ & $\mathrm{H}_{2} \mathrm{O}$ & $\mathrm{KCl}$ & $\mathrm{Ca}^{2+}$ & $\mathrm{Mg}^{2+}$ & $\mathrm{K}^{+}$ & $\mathrm{Na}^{+}$ & $\mathrm{Al}^{3+}$ & $\mathrm{H}^{+}$ & & & & & & \\
\hline Ap & $0-10$ & 5.3 & 4.7 & 19 & 3 & 1,6 & 0,2 & 3 & 43 & 23,8 & 69,8 & 24 & 11 & 6 & 9,8 \\
\hline A2 & $10-70$ & 5.1 & 4.6 & 15 & 1 & 0,9 & 0,2 & 3 & 45 & 17,1 & 65,1 & 26 & 15 & 3 & 11,6 \\
\hline A3 & $70-130 / 140$ & 5.2 & 4.1 & 7 & 1 & 0,5 & 0,2 & 8 & 42 & 8,7 & 58,7 & 15 & 48 & 3 & 8,7 \\
\hline$E$ & $130 / 140-170 / 180$ & 5.0 & 4.1 & 4 & 1 & 0,2 & 0,2 & 6 & 44 & 5,4 & 55,4 & 10 & 53 & 3 & 5,8 \\
\hline $\mathrm{E} / \mathrm{B}$ & $170 / 180-200$ & 4.9 & 3.9 & 5 & 1 & 0,5 & 0,2 & 9 & 35 & 6,7 & 50,7 & 13 & 57 & 3 & 5,8 \\
\hline
\end{tabular}

ATRIBUTOS MINERALOGICOS DO PERFIL No 41

\begin{tabular}{ccccccccccccc}
\hline \multicolumn{2}{c}{ Horizonte (cam) } & \multicolumn{3}{c}{ ataque com $\mathrm{H}_{2} \mathrm{SO}_{4}$} & \multicolumn{3}{c}{ Relações } & \multicolumn{2}{c}{$\%$ da AF } & \multicolumn{2}{c}{ DRX } \\
\hline Tipo & Prof. $(\mathrm{cm})$ & $\mathrm{SiO}_{2}$ & $\mathrm{Al}_{2} \mathrm{O}_{3}$ & $\mathrm{Fe}_{2} \mathrm{O}_{3}$ & $\mathrm{TiO}_{2}$ & $\mathrm{Mn} \mathrm{O}$ & $\mathrm{Ki}$ & $\mathrm{Kr}$ & Leves Pesados & argila & silte \\
\hline Ap & $0-10$ & 1,70 & 1,37 & 0,20 & 0,17 & 0,04 & $2,111,93$ & 99,0 & 1,0 & $\mathrm{C}, \mathrm{V}, \mathrm{Mi}$ & $\mathrm{P}, \mathrm{Q}$ \\
$\mathrm{A} 3$ & $70-130 / 140$ & 2,00 & 3,31 & 0,54 & 0,26 & 0,01 & $1,030,93$ & 99,0 & 1,0 & - & - \\
$\mathrm{E}$ & $130 / 140-170 / 180$ & 3,50 & 1,02 & 0,33 & 0,20 & 0,01 & $5,834,83$ & 99,0 & 1,0 & - & - \\
$\mathrm{E} / \mathrm{B}$ & $170 / 180-200$ & 2,80 & 1,78 & 0,54 & 0,21 & 0,01 & $2,672,23$ & 99,0 & 1,0 & $\mathrm{C}, \mathrm{V}, \mathrm{Mi}$ & $\mathrm{P}, \mathrm{Q}$ \\
\hline
\end{tabular}

COMPOSIÇÃO QUÍMICA ELEMENTAL DA FRAÇÃO AREIA FINA DO PERFIL 41

\begin{tabular}{cccccccccccc}
\hline Horiz/cam & \multicolumn{8}{c}{ INFLUORESCÊNCIA DE RAIO X $(\%)$} & Zr \\
\hline & $\mathrm{SiO}_{2}$ & $\mathrm{Al}_{2} \mathrm{O}_{3}$ & $\mathrm{Fe}_{2} \mathrm{O}_{3}$ & $\mathrm{TiO}_{2}$ & $\mathrm{MnO}$ & $\mathrm{CaO}$ & $\mathrm{MgO}$ & $\mathrm{K}_{2} \mathrm{O}$ & $\mathrm{Na}_{2} \mathrm{O}$ & $\mathrm{P}_{2} \mathrm{O}_{5}$ & $\mathrm{ppm}$ \\
\hline $\mathrm{Ap}$ & 98,2308 & 0,7776 & 0,2874 & 0,0891 & 0,0079 & 0,0346 & 0,0540 & 0,0518 & 0,0332 & 0,0144 & 27 \\
$\mathrm{~A} 2$ & 98,7375 & 0,7222 & 0,2818 & 0,0880 & 0,0117 & 0,0252 & 0,0000 & 0,0465 & 0,0142 & 0,0136 & 20 \\
$\mathrm{~A} 3$ & 98,7507 & 0,7049 & 0,2820 & 0,0890 & 0,0018 & 0,0245 & 0,0000 & 0,0448 & 0,0304 & 0,0123 & 24 \\
$\mathrm{E}$ & 98,6433 & 0,6588 & 0,2437 & 0,0859 & 0,0006 & 0,0222 & 0,0000 & 0,0459 & 0,0304 & 0,0108 & 11 \\
$\mathrm{E} / \mathrm{B}$ & 98,3743 & 0,7483 & 0,2616 & 0,0935 & 0,0006 & 0,0192 & 0,0000 & 0,0471 & 0,0246 & 0,0120 & 67 \\
\hline
\end{tabular}


PERFIL: No 42

\section{A. DESCRICÃO GERAL}

CLASSIFICACÃ̃: Latossolo Vermelho-amarelo álico A moderado textura média/argilosa fase floresta subtropical subperennifolia, substrato arenito, relevo ondulado. LOCALIZACÃO: $20 \mathrm{~m}$ a Oeste do caminho na propriedade do Sr. Ortiz.

COORD. UTM: E0512450/N7123000

RELEVO LOCAL: ondulado

ALTITUDE: 310 m.s.n.m.

DECLIVE: $6 \%$

DIREÇÃO: Oeste

LITOLOGIA: Arenito sacoroidal

ROCHOSIDADE: nula

PROF. DO LENCOL: $1,7 \mathrm{~m}$

INUNDACÕES: nula

EROSÃO: laminar moderado

PRODUTIVIDADE: media

DESCRITO POR: Sérgio M. Burgos Sosa

UN PEDOGEOMÓRFICA: 3c

RELEVO REGIONAL: ondulado a forte ondulado

POSIĈÃO TOP: encosta média

COMPRIMENTO: $700 \mathrm{~m}$

FORMACẼO GEOL.: "Tovati"

MAT. PARENTAL: saprolito de arenito sacoroidal

PEDREGOSIDADE: nula

DRENAGEM: bem drenado

VEGET. PRIMÁRIA: Floresta subtropical subperennifolia

USO ATUAL: pastoreio

CLIMA: temperado chuvoso (cfa)

\section{B. DESCRIÇÃO MORFOLÓGICA}

A1 0-10 cm; bruno avermelhado escuro (5 YR 3/4, úmido); bruno avermelhado (5 YR 5/4, seco); franco argilo-arenosa; moderado pequena a grande granular e blocos subangulares; ligeiramente duro, friável, ligeiramente plástico e ligeiramente pegajoso; transição clara e ondulada.

A2 10-30 cm; bruno avermelhado (5 YR 4/4, úmido), vermelho amarelado (5 YR 5/6, seco); franco argilo-arenosa; moderado media a grande blocos subangulares; ligeiramente duro, friável, ligeiramente plástico e ligeiramente pegajoso; transição gradual e plana.

A3 30-60 cm; bruno avermelhado (5 YR 4/4, úmido), vermelho amarelado (5 YR 4/6, seco); franco argilo-arenosa; moderado media a grande blocos subangulares; ligeiramente duro, friável, plástico e pegajoso; transição gradual e ondulada.

$\mathrm{AB}$ 60-100 cm; bruno avermelhado (5 YR 4/4, úmido); vermelho amarelado (5 YR 5/6, seco), franco argilo-arenosa; moderado media a grande blocos subangulares; ligeiramente duro, friável, plástico e pegajoso; transição gradual e plana.

Bwl 100-120 cm; vermelho escuro (2.5 YR 3/6, úmido); vermelho amarelado (5 YR 5/6, seco); argila arenosa; forte media a muito grande blocos subangulares; cerosidade fraca, muito pouca em canais e inter-grãos; duro, muito friável, ligeiramente plástico e pegajoso; transição gradual e plana.

Bw2 120-170 cm +; vermelho escuro (2.5 YR 3/6, úmido); vermelho (2.5 YR 4/8, seco); argilaarenosa; forte media a grande blocos subangulares; cerosidade fraca e pouca em canais e intergrãos; duro, muito friável, ligeiramente plástico e pegajoso, transição difusa e plana.

C 250-290 cm; vermelho escuro (2.5 YR 3/6, úmido), vermelho (2.5 YR 4/8, seco); argila arenosa; ligeiramente plástico e ligeiramente pegajoso.

RAIZES: abundantes, muito finas e media no $\mathrm{A} 1$, comuns e muito finas no $\mathrm{A} 2, \mathrm{~A} 3$ e $\mathrm{AB}$, poucas e muito finas no Bwl e Bw2.

OBSERVAÇÕES: poucas concresões de ferro, pequenas, duras, irregulares de cor bruno escuro em todo o perfil; camada C $(250-290 \mathrm{~cm})$ amostrada com trado por causa da elevação do lençol freático. 
ATRIBUTOS FÍSICOS DO PERFIL No 42

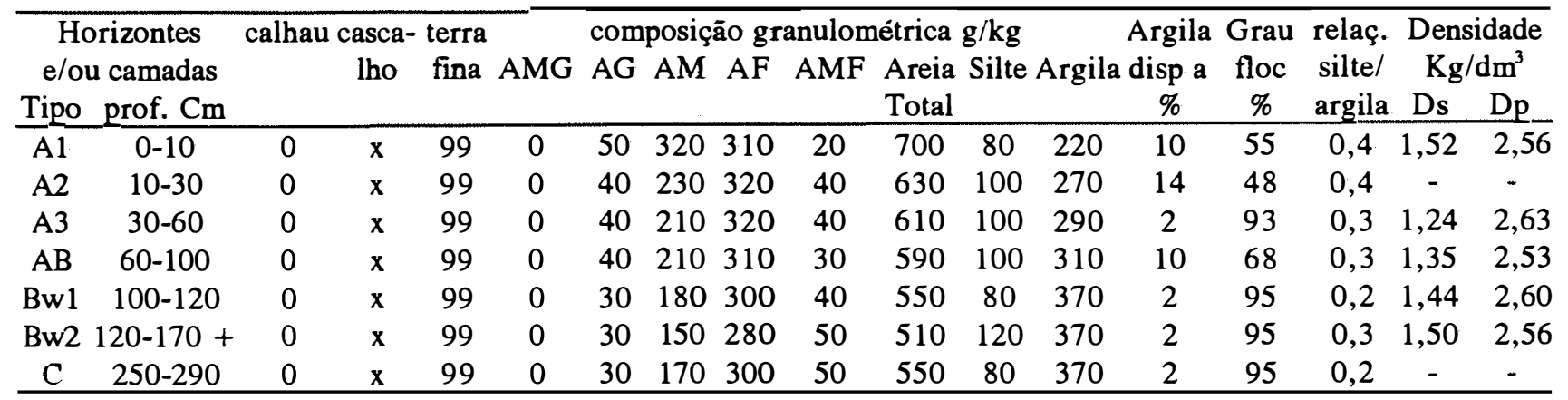

ATRIBUTOS QUIMICOS, DO PERFIL N ${ }^{\circ} 42$

\begin{tabular}{|c|c|c|c|c|c|c|c|c|c|c|c|c|c|c|c|}
\hline \multicolumn{2}{|c|}{ Horiz e/ou cam. } & \multicolumn{2}{|c|}{ PH. } & \multicolumn{6}{|c|}{ Complexo sortivo $(\mathrm{mmol} / \mathrm{Kg})$} & \multirow{2}{*}{$\begin{array}{c}\text { Valor } \\
S \\
\end{array}$} & \multirow{2}{*}{$\begin{array}{c}\text { Valor } \\
\mathrm{T}\end{array}$} & \multirow[t]{2}{*}{$\mathrm{V} \%$} & \multirow[t]{2}{*}{$\mathrm{m} \%$} & \multirow{2}{*}{$\frac{\mathrm{P}}{\mathrm{mg} / \mathrm{kg}}$} & \multirow{2}{*}{$\begin{array}{l}\text { C org. } \\
\text { g. } \mathrm{kg}^{-1}\end{array}$} \\
\hline Tipo & Prof. cm & $\mathrm{H}_{2} \mathrm{O}$ & $\mathrm{KCl}$ & $\mathrm{Ca}^{2+}$ & $\mathrm{Mg}^{2+}$ & $\mathrm{K}^{+}$ & $\mathrm{Na}^{+}$ & $\mathrm{Al}^{3+}$ & $\mathrm{H}^{+}$ & & & & & & \\
\hline $\mathrm{A} 1$ & $0-10$ & 5.2 & 4.1 & 18 & 11 & 3,4 & 0,3 & 4 & 60 & 32,7 & 96,7 & 34 & 11 & 5 & 15,6 \\
\hline A2 & $10-30$ & 5.0 & 3.8 & 11 & 6 & 0,8 & 0,3 & 11 & 59 & 18,1 & 88,1 & 21 & 38 & 5 & 12,7 \\
\hline A3 & $30-60$ & 4.8 & 3.6 & 7 & 3 & 0,7 & 0,4 & 19 & 61 & 11,1 & 91,4 & 12 & 63 & 2 & 9,8 \\
\hline$A B$ & $60-100$ & 5.0 & 3.7 & 8 & 3 & 0,8 & 0,2 & 20 & 68 & 12,0 & 100,0 & 12 & 63 & 3 & 8,7 \\
\hline Bw1 & $100-120$ & 4.8 & 3.7 & 3 & 1 & 0,9 & 0,2 & 18 & 62 & 5,1 & 85,1 & 6 & 78 & 5 & 7,5 \\
\hline Bw2 & $120-170+$ & 5.0 & 3.7 & 4 & 1 & 1,1 & 0,2 & 19 & 22 & 6,6 & 47,6 & 14 & 74 & 5 & 7,5 \\
\hline C & $250-290$ & 4.9 & 3.6 & 3 & 1 & 0,8 & 0,2 & 24 & 56 & 5,0 & 85,0 & 6 & 83 & 5 & 4,6 \\
\hline
\end{tabular}

ATRIBUTOS MINERALOGICOS DO PERFIL No 42

\begin{tabular}{ccccccccccccc}
\hline \multicolumn{1}{c}{ Horizonte (cam) } & \multicolumn{9}{c}{ ataque com $\mathrm{H}_{2} \mathrm{SO}_{4}$} & \multicolumn{5}{c}{ Relações } & \multicolumn{2}{c}{ \% da AF } & \multicolumn{2}{c}{$\mathrm{DRX}$} \\
\hline Tipo & Prof. $(\mathrm{cm})$ & $\mathrm{SiO}_{2}$ & $\mathrm{Al}_{2} \mathrm{O}_{3}$ & $\mathrm{Fe}_{2} \mathrm{O}_{3}$ & $\mathrm{TiO}_{2}$ & $\mathrm{Mn} \mathrm{O}$ & $\mathrm{Ki}$ & $\mathrm{Kr}$ & Leves & Pesados & argila & silte \\
\hline $\mathrm{Ap}$ & $0-10$ & 7,70 & 5,05 & 2,07 & 0,45 & 0,03 & $2,592,05$ & 100 & 0 & & - & - \\
$\mathrm{AB}$ & $60-100$ & 11,80 & 8,77 & 4,01 & 0,72 & 0,02 & $2,291,77$ & 100 & 0 & $\mathrm{C}, \mathrm{V}, \mathrm{Mi}$ & $\mathrm{P}, \mathrm{Q}$ \\
$\mathrm{Bw} 2$ & $120-170$ & 10,20 & 9,68 & 4,48 & 0,87 & 0,01 & 1,79 & 1,38 & 99,5 & 0,5 & $\mathrm{C}, \mathrm{V}, \mathrm{Mi}$ & $\mathrm{P}, \mathrm{Q}$ \\
$\mathrm{C}$ & $250-290$ & 9,30 & 9,28 & 2,86 & 0,73 & 0,01 & $1,701,42$ & 99,5 & 99,5 & - & - \\
\hline
\end{tabular}

COMPOSIÇÃO QUÍMICA ELEMENTAL DA FRAÇÃO AREIA FINA DO PERFIL 42

\begin{tabular}{cccccccccccc}
\hline Horiz/cam & \multicolumn{8}{c}{ INFLUORESCENCIA DE RAIO X $(\%)$} & \multicolumn{2}{c}{$\mathrm{Zr}$} \\
\hline & $\mathrm{SiO}_{2}$ & $\mathrm{Al}_{2} \mathrm{O}_{3}$ & $\mathrm{Fe}_{2} \mathrm{O}_{3}$ & $\mathrm{TiO}_{2}$ & $\mathrm{MnO}$ & $\mathrm{CaO}$ & $\mathrm{MgO}$ & $\mathrm{K}_{2} \mathrm{O}$ & $\mathrm{Na} \mathrm{O}_{2}$ & $\mathrm{P}_{2} \mathrm{O}_{5}$ & ppm \\
\hline $\mathrm{A} 1$ & 98,5581 & 0,4485 & 0,2332 & 0,0920 & 0,0025 & 0,0220 & 0,0000 & 0,0340 & 0,0154 & 0,0152 & 62 \\
$\mathrm{~A} 2$ & 97,9939 & 0,6968 & 0,7224 & 0,0813 & 0,0058 & 0,0191 & 0,0000 & 0,0277 & 0,0326 & 0,0105 & 9 \\
$\mathrm{~A} 3$ & 98,1536 & 0,6072 & 0,5975 & 0,0706 & 0,0019 & 0,0182 & 0,0040 & 0,0259 & 0,0394 & 0,0097 & 10 \\
$\mathrm{AB}$ & 97,2571 & 0,6225 & 0,7024 & 0,0837 & 0,0041 & 0,0185 & 0,0000 & 0,0260 & 0,0209 & 0,0076 & 24 \\
$\mathrm{Bw} 1$ & 98,3851 & 0,5150 & 0,4963 & 0,0936 & 0,0033 & 0,0241 & 0,0000 & 0,0169 & 0,0354 & 0,0076 & 49 \\
$\mathrm{Bw} 2$ & 98,3330 & 0,6966 & 0,6966 & 0,0828 & 0,0023 & 0,0223 & 0,0000 & 0,0304 & 0,0442 & 0,0018 & 10 \\
$\mathrm{C}$ & 98,5156 & 0,6450 & 0,6237 & 0,0770 & 0,0015 & 0,0242 & 0,0000 & 0,0294 & 0,0242 & 0,0097 & $(-)$ \\
\hline
\end{tabular}




\section{A. DESCRICÃO GERAL}

PERFIL: $\mathrm{N}^{\circ} 43$

CLASSIFICACÃ̃: Cambissolo álico petroplíntico Tb A moderado textura média/argilosa, fase floresta subtropical subperennifolia, substrato arenito, relevo ondulado.

LOCALIZACÃ̃: $800 \mathrm{~m}$ ao Oeste do caminho na propriedade do Sr. Ortiz.

COORD. UTM: E0512100/N7123050 UN PEDOGEOMÓRFICA: 3d

RELEVO LOCAL: ondulado

ALTITUDE: 275 m.s.n.m.

DECLIVE: $10 \%$

DIRECÃO: oeste

LITOLOGIA: Arenito arcosiano

ROCHOSIDADE: nula

RELEVO REGIONAL: ondulado a forte ondulado

POSIČÃO TOP: encosta inferior

COMPRIMENTO: $200 \mathrm{~m}$

FORMAČ̃̃ GEOL.: "Cerro hũ"

MAT. PARENTAL: saprólito de arenito arcosiano

PEDREGOSIDADE: nula

PROF. DO LENCOL: $>2 \mathrm{~m}$

INUNDACÕES: nula

DRENAGEM: moderadamente drenado

VEGET. PRIMÁRIA: Floresta subtropical subperennifolia

EROSÃO: laminar moderado

PRODUTIVIDADE: média

DESCRITO POR: Sérgio M. Burgos Sosa

USO ATUAL: pastoreio

CLIMA: temperado chuvoso (cfa)

\section{B. DESCRIÇÃO MORFOLÓGICA}

Ap 0-8 cm, bruno escuro (7.5 YR 3/3, úmido), bruno (7.5 YR 5/3, seco); franco-arenosa; fraca muito pequena granular; ligeiramente duro, friável, ligeiramente plástico e ligeiramente pegajoso; transição clara e plana.

A2 8-30 cm; bruno escuro (7.5 YR 3/4, úmido), bruno (7.5 YR 5/4, seco); franco argilo-arenosa; moderado média a grande blocos subangulares; ligeiramente duro, friável; ligeiramente plástico e ligeiramente pegajoso; transição gradual e plana.

$\mathrm{Bi} \quad 30-52 / 58 \mathrm{~cm}$; bruno escuro (7.5 YR 4/4, úmido), bruno forte (7.5 YR 5/6, seco); argila arenosa; moderado média a grande blocos subangulares; cerosidade fraca, pouca em canais e inter-grãos; ligeiramente duro, friável, ligeiramente plástico e pegajoso; transição abrupta e ondulada.

Cc 52/58-120/130 cm; vermelho escuro (2.5 YR 3/6, úmido), vermelho (10 R 4/6, seco); mosqueados poucos pequenos resaltante de cor bruno amarelado (10 YR 5/8, úmido); argila; maciço por parte; duro, friável, ligeiramente plástico e pegajoso; transição abrupta e descontínua.

RAIZES: abundantes e muito finas a finas no $\mathrm{Ap}$; comuns muito finas e fina no $\mathrm{A} 2$ e $\mathrm{Bi}$; comuns e muito finas no Cc.

OBSERVAÇÕES: poucas concresões de ferro pequenas, duras, irregulares de cor bruno escuro no A1, $\mathrm{A} 2 \mathrm{e} \mathrm{Bi}$; dominantes concresões de ferro pequenas e grandes, duras, irregulares de cor bruno escuro no Cc.; $10 \%$ de fragmento de rocha e um calhau de quartzo arredondado e quebrado no Cc. 
ATRIBUTOS FÍSICOS DO PERFIL $\mathrm{N}^{\circ} 43$

\begin{tabular}{|c|c|c|c|c|c|c|c|c|c|c|c|c|c|c|c|c|c|}
\hline \multicolumn{2}{|c|}{$\begin{array}{l}\text { Horizontes } \\
\text { e/ou camadas }\end{array}$} & \multicolumn{16}{|c|}{ calhau casca- terra COMPOSIÇĀO GRANULOMETRICA g/Kg ArgilaGra Relaç. Densidade } \\
\hline ipo & Prof. $\mathrm{cm}$ & & & & & & & & & Total & & & $\%$ & $\%$ & argila & Ds & Dr \\
\hline & & & & & 10 & 50 & & & & & & & & 70 & $0, \overline{5}$ & 1,40 & 2,56 \\
\hline & & & & & ( & d & 20 & & & & & & & 9 & & - & \\
\hline $\mathrm{Bi}$ & & & & & 0 & 30 & 170 & 260 & 40 & & 40 & & & 89 & 4 & 1,28 & 2,60 \\
\hline Cc & $52 / 58-120 / 130$ & 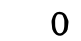 & 26 & 14 & 60 & 60 & 120 & 170 & 30 & 440 & 130 & 430 & 2 & 95 & 0,3 & - & - \\
\hline
\end{tabular}

ATRIBUTOS QUIMICOS, DO PERFIL Nº 43

\begin{tabular}{|c|c|c|c|c|c|c|c|c|c|c|c|c|c|c|}
\hline \multicolumn{2}{|c|}{ Horiz e/ou cam. } & \multirow{2}{*}{$\frac{\mathrm{PH}_{.}}{\mathrm{H}_{2} \mathrm{O} \mathrm{KCl}}$} & \multicolumn{6}{|c|}{ Complexo sortivo $(\mathrm{mmol} / \mathrm{Kg})$} & \multirow{2}{*}{$\frac{\text { Valor }}{S}$} & \multirow{2}{*}{$\frac{\text { Valor }}{\mathrm{T}}$} & \multirow[t]{2}{*}{$\mathrm{V} \%$} & \multirow[t]{2}{*}{$\mathrm{m} \%$} & \multirow{2}{*}{$\frac{\mathrm{P}}{\mathrm{mg} / \mathrm{kg}}$} & \multirow{2}{*}{$\frac{\mathrm{C} \text { org. }}{\mathrm{g} \cdot \mathrm{kg}^{-1}}$} \\
\hline Tipo & Prof. $\mathrm{cm}$ & & $\mathrm{Ca}^{2+}$ & $\mathrm{Mg}^{2+}$ & $\mathrm{K}^{+}$ & $\mathrm{Na}^{+}$ & $\mathrm{Al}^{3+}$ & $\mathrm{H}^{+}$ & & & & & & \\
\hline$A p$ & $0-8$ & 5.03 .9 & 18 & 6 & 1,1 & 0,4 & 10 & 42 & 25,5 & 77,5 & 33 & 28 & 3 & 19,6 \\
\hline $\mathrm{A} 2$ & $8-30$ & 4.73 .6 & 9 & 1 & 0,5 & 0,2 & 19 & 71 & 10,7 & 100,7 & 11 & 64 & 2 & 8,7 \\
\hline $\mathrm{Bi}$ & $30-52 / 58$ & $\begin{array}{ll}4.8 & 3.7\end{array}$ & 6 & 1 & 0,5 & 0,2 & 23 & 51 & 7,7 & 75,7 & 10 & 75 & 2 & 11,6 \\
\hline $\mathrm{Cc}$ & $52 / 58-120 / 130$ & $5.8 \quad 3.7$ & 5 & 1 & 0,8 & 0,2 & 26 & 64 & 7,0 & 97,0 & 7 & 79 & 4 & 5,8 \\
\hline
\end{tabular}

ATRIBUTOS MINERALOGICOS DO PERFIL No 43

\begin{tabular}{|c|c|c|c|c|c|c|c|c|c|c|c|c|}
\hline \multicolumn{2}{|c|}{ Horizonte (cam) } & \multicolumn{5}{|c|}{ ataque com $\mathrm{H}_{2} \mathrm{SO}_{4}$} & \multicolumn{2}{|c|}{ Relações } & \multicolumn{2}{|c|}{$\%$ da $\mathrm{AF}$} & \multicolumn{2}{|c|}{ DRX } \\
\hline Tipo & Prof. (cm) & $\mathrm{SiO}_{2}$ & $\mathrm{Al}_{2} \mathrm{O}_{3}$ & $\mathrm{Fe}_{2} \mathrm{O}_{3}$ & $\mathrm{TiO}_{2}$ & $\mathrm{Mn} \mathrm{O}$ & $\mathrm{Ki}$ & $\mathrm{Kr}$ & Leves & Pesados & argila & Silte \\
\hline $\mathrm{Ap}$ & $0-8$ & 5,8 & 5,51 & 2,95 & 0,74 & 0,01 & 1,79 & 1,33 & - & - & - & - \\
\hline $\mathrm{Bi}$ & $30-52 / 58$ & 11,0 & 8,87 & 4,30 & 0,83 & 0,01 & 2,11 & 1,61 & 98,0 & 2,0 & $\mathrm{C}, \mathrm{V}, \mathrm{Mi}$ & $\mathrm{P}, \mathrm{Q}$ \\
\hline $\mathrm{Cc}$ & $52 / 58-120 / 130$ & 17,0 & 13,51 & 7,61 & 1,33 & 0,01 & 2,14 & 1,57 & 95,0 & 5,0 & $\mathrm{C}, \mathrm{V}, \mathrm{Mi}$ & $\mathrm{P}, \mathrm{Q}$ \\
\hline
\end{tabular}

COMPOSIÇÃO QUÍMICA ELEMENTAL DA FRAÇÃO AREIA FINA DO PERFIL 43

\begin{tabular}{|c|c|c|c|c|c|c|c|c|c|c|c|}
\hline Horiz/cam & & & INF & FLUORI & ESCÊNC & IA DE $\mathrm{F}$ & AIO X & & & & $\mathrm{Zr}_{\mathrm{r}}$ \\
\hline & $\mathrm{SiO}_{2}$ & $\mathrm{Al}_{2} \mathrm{O}_{3}$ & $\mathrm{Fe}_{2} \mathrm{O}_{3}$ & $\mathrm{TiO}_{2}$ & $\mathrm{MnO}$ & $\mathrm{CaO}$ & $\mathrm{MgO}$ & $\mathrm{K}_{2} \mathrm{O}$ & $\mathrm{Na}_{2} \mathrm{O}$ & $\mathrm{P}_{2} \mathrm{O}_{5}$ & ppm \\
\hline Ap & 98,4437 & 0,6546 & 0,6114 & 0,1037 & 0,0026 & 0,0245 & 0,0000 & 0,0210 & 0,0394 & 0,0101 & 41 \\
\hline A2 & 93,8813 & 5,1337 & 0,5239 & 0,0866 & 0,0018 & 0,0175 & 0,0000 & 0,0163 & 0,0216 & 0,0075 & 13 \\
\hline $\mathrm{Bi}$ & 98,1356 & 0,6916 & 0,7170 & 0,0852 & 0,0055 & 0,0221 & 0,0000 & 0,0296 & 0,0354 & 0,0099 & 53 \\
\hline $\mathrm{Cc}$ & 90,7792 & 2,9434 & 4,5380 & 0,1736 & 0,0026 & 0,0286 & 0,0000 & 0,0653 & 0,1054 & 0,0417 & 62 \\
\hline
\end{tabular}


PERFIL: $N^{\circ} 44$

\section{A. DESCRICÃO GERAL}

CLASSIFICACAÃO: Podzólico Vermelho-amarelo álico petroplíntico Tb A moderado textura media/argilosa, fase floresta subtropical subperennifolia, substrato arenito, relevo ondulado.

LOCALIZACÃ̃: $1000 \mathrm{~m}$ a Oeste do caminho na propriedade do Sr. Ortiz.

COORD. UTM: E0511950/N7123100 UN PEDOGEOMÓRFICA: 3d

RELEVO LOCAL: ondulado

ALTITUDE: 260 m.s.n.m.

DECLIVE: $10 \%$

RELEVO REGIONAL: ondulado a forte ondulado

DIREÇ̃̃O: Oeste

POSIĈ̃̃ TOP: encosta inferior

LITOLOGIA: Arenito arcosiano

COMPRIMENTO: $200 \mathrm{~m}$

ROCHOSIDADE: nula

FORMACÃ̃ GEOL.: "Cerro hũ"

PROF. DO LENCOL: $>2 \mathrm{~m}$

MAT. PARENTAL: saprólito de arenito arcosiano.

PEDREGOSIDADE: nula

INUNDACÕES: nula

DRENAGEM: bem drenado

EROSÃO: laminar moderado

VEGET. PRIMÁRIA: Floresta subtropical subperennifolia

USO ATUAL: pastoreio

PRODUTIVIDADE: média

DESCRITO POR: Sérgio M. Burgos Sosa

\section{B. DESCRICÃO MORFOLÓGICA}

Ap 0-10 cm, bruno escuro (7.5 YR 3/3, úmido e 7.5 YR 4/3, seco); franco argilo-arenosa; moderado muito pequena a media granular; ligeiramente duro, friável, não plástico e não pegajoso; transição clara e plana.

A2 10-40 cm; bruno avermelhado escuro (5 YR 3/4, úmido), bruno avermelhado (5 YR 4/4, seco); franco argilo-arenosa; moderada pequena a media blocos subangulares; cerosidade fraca em canais e inter-grãos, duro, friável, ligeiramente plástico e ligeiramente pegajoso; transição gradual e plana.

Bt1 40-70 cm; bruno avermelhado escuro (2.5 YR 3/4, úmido), vermelho (2.5 YR 4/6, seco); argila arenosa, forte média a grande blocos subangulares; cerosidade moderado pouca em canais, superfície de agregados e inter-grãos; duro; muito friável, plástico e pegajoso; transição difusa e plana.

Bt2w 70 - $110 \mathrm{~cm}$; vermelho escuro (2.5 YR 3/6, úmido), vermelho (2.5 YR 1/6, seco); argila arenosa; forte média a grande blocos subangulares; cerosidade moderado e comum em canais $\mathrm{e}$ superfície de agregados; duro, muito friável, plástico e pegajoso; transição difusa e plana.

Bt3 110-150/170 cm; vermelho escuro (2.5 YR 3/6, úmido), vermelho (2.5 YR 4/6, seco); argila; moderado pequena a média blocos subangulares; cerosidade fraca, pouca, inter-grãos; duro, muito friável; ligeiramente plástico e pegajoso; transição abrupta e descontínua.

Cc 150/170 cm +; vermelho escuro (2.5 YR 3/6, úmido), vermelho (2.5 YR 4/6, seco); argila poucos mosqueados, pequeno, distinto de cor bruno avermelhado (10 YR 5/8, úmido); argila; maciço; extremamente duro, muito friável, ligeiramente plástico e ligeiramente pegajoso.

RAIZES: abundantes muito finas e grossas no Ap, abundantes e muito finas a médias no A2, comuns e muito finas a médias no Bt1 e Bt2, poucas e muito finas no Bt3 e raras e muito finas no $\mathrm{Cc}$.

OBSERVAÇÕES: poucas concresões de ferro, pequenas; duras e irregulares em quase todo o perfil; passando para frequente na camada Cc; cascalho de quartzo arredondados e outros fragmentos de arenito no Cc. 
ATRIBUTOS FÍSICOS DO PERFIL N ${ }^{\circ} 44$

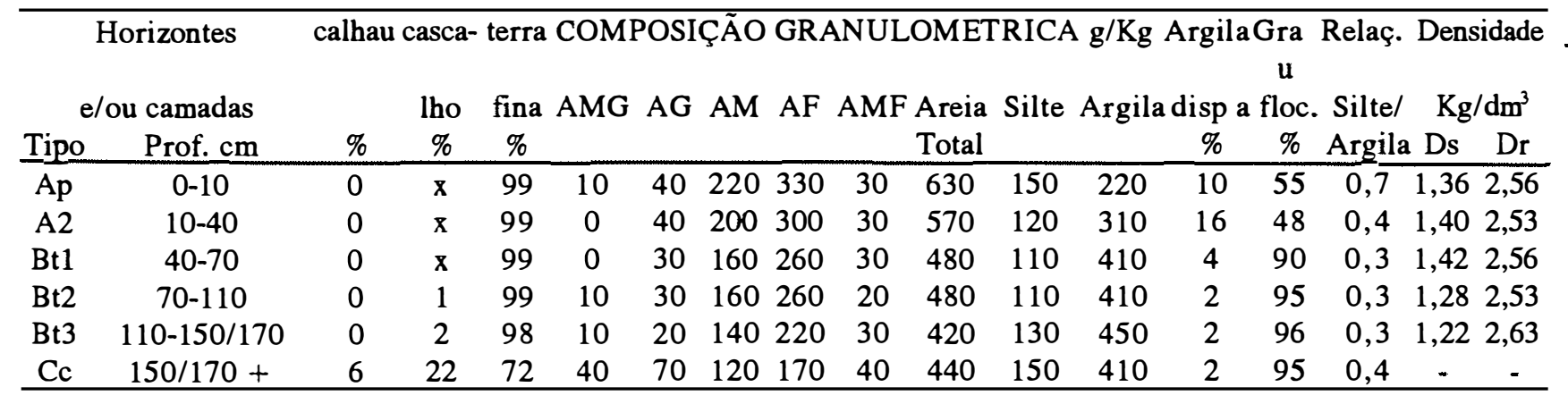

ATRIBUTOS QUIMICOS, DO PERFIL N 44

\begin{tabular}{|c|c|c|c|c|c|c|c|c|c|c|c|c|c|c|c|}
\hline \multicolumn{2}{|c|}{ Horiz e/ou cam. } & \multicolumn{2}{|c|}{ PH. } & \multicolumn{6}{|c|}{ Complexo sortivo (mmol/Kg) } & \multirow{2}{*}{$\frac{\text { Valor }}{S}$} & \multirow{2}{*}{$\frac{\text { Valor }}{\mathrm{T}}$} & \multirow[t]{2}{*}{$\mathrm{V} \%$} & \multirow[t]{2}{*}{$\mathrm{m} \%$} & \multirow{2}{*}{$\frac{\mathrm{P}}{\mathrm{mg} / \mathrm{kg}}$} & \multirow{2}{*}{$\frac{C \text { org. }}{\text { g. } \text { kg }^{-1}}$} \\
\hline Tipo & Prof. $\mathrm{cm}$ & $\mathrm{H}_{2} \mathrm{O}$ & $\mathrm{KCl}$ & $\mathrm{Ca}^{2+}$ & $\mathrm{Mg}^{2+}$ & $\mathrm{K}^{+}$ & $\mathrm{Na}^{+}$ & $\mathrm{Al}^{3+}$ & $\mathrm{H}^{+}$ & & & & & & \\
\hline Ap & $0-10$ & 5.1 & 4.2 & 23 & 10 & 2,5 & 0,2 & 7 & 53 & 35,7 & 95,7 & 37 & 16 & 5 & 17,9 \\
\hline A2 & $10-40$ & 5.1 & 3.8 & 20 & 6 & 0,5 & 0,2 & 8 & 54 & 26,7 & 88,7 & 30 & 23 & 4 & 12,7 \\
\hline Bt1 & $40-70$ & 5.0 & 3.7 & 15 & 3 & 0,5 & 0,2 & 17 & 47 & 18,7 & 82,7 & 23 & 48 & 2 & 11,6 \\
\hline Bt2 & $70-110$ & 5.0 & 3.6 & 16 & 3 & 0,6 & 0,2 & 17 & 49 & 19,8 & 85,8 & 23 & 46 & 2 & 9,8 \\
\hline $\mathrm{Bt} 3$ & $110-150 / 170$ & 5.2 & 3.7 & 13 & 3 & 0,6 & 0,3 & 17 & 42 & 16,9 & 75,9 & 22 & 50 & 2 & 8,7 \\
\hline $\mathrm{Cc}$ & $150 / 170+$ & 5.3 & 3.9 & 10 & 3 & 0,7 & 0,4 & 8 & 71 & 14,1 & 93,1 & 15 & 36 & 4 & 5,8 \\
\hline
\end{tabular}

ATRIBUTOS MINERALOGICOS DO PERFIL N ${ }^{\circ} 44$

\begin{tabular}{ccccccccccccc}
\hline \multicolumn{1}{c}{ Horizonte (cam) } & \multicolumn{9}{c}{ ataque com $\mathrm{H}_{2} \mathrm{SO}_{4}$} & \multicolumn{5}{c}{ Relações } & \multicolumn{2}{c}{ da AF } & \multicolumn{3}{c}{ DRX } \\
\hline Tipo & Prof. (cm) & $\mathrm{SiO}_{2}$ & $\mathrm{Al}_{2} \mathrm{O}_{3}$ & $\mathrm{Fe}_{2} \mathrm{O}_{3}$ & $\mathrm{TiO}_{2}$ & $\mathrm{MnO}$ & $\mathrm{Ki}$ & $\mathrm{Kr}$ & Leves & Pesados & argila & silte \\
\hline Ap & $0-10$ & 7,71 & 5,66 & 1,72 & 0,57 & 0,03 & 2,32 & 1,94 & 99,5 & 0,5 & - & - \\
$\mathrm{Bt} 2$ & $70-110$ & 14,00 & 11,47 & 4,61 & 0,99 & 0,01 & 2,07 & 1,65 & 99,5 & 0,5 & $\mathrm{C}, \mathrm{V}, \mathrm{Mi}$ & $\mathrm{P}, \mathrm{Q}$ \\
$\mathrm{Bt3}$ & $110-150 / 170$ & 14,60 & 12,34 & 4,27 & 0,87 & 0,01 & 2,01 & 1,65 & 99,5 & 0,5 & - & - \\
$\mathrm{Cc}$ & $150 / 170+$ & 17,10 & 14,47 & 10,40 & 1,54 & 0,01 & 2,04 & 1,39 & 99,0 & 1,0 & $\mathrm{C}, \mathrm{Mi}, \mathrm{V}$ & $\mathrm{P}, \mathrm{Q}$ \\
\hline
\end{tabular}

COMPOSIÇÃO QUÍMICA ELEMENTAL DA FRAÇÃO AREIA FINA DO PERFIL 44

\begin{tabular}{|c|c|c|c|c|c|c|c|c|c|c|c|}
\hline \multirow{2}{*}{ Horiz/cam } & \multicolumn{10}{|c|}{ INFLUORESCÊNCIA DE RAIO X (\%) } & \multirow{2}{*}{$\frac{\mathrm{Zr}}{\mathrm{ppm}}$} \\
\hline & $\mathrm{SiO}_{2}$ & $-\mathrm{Al}_{2} \mathrm{O}_{3}$ & $\mathrm{Fe}_{2} \mathrm{O}_{3}$ & $\mathrm{TiO}_{2}$ & $\mathrm{MnO}$ & $\mathrm{CaO}$ & $\mathrm{MgO}$ & $\mathrm{K}_{2} \mathrm{O}$ & $\mathrm{Na}_{2} \mathrm{O}$ & $\mathrm{P}_{2} \mathrm{O}_{5}$ & \\
\hline Ap & 98,6958 & 0,5578 & 0,4744 & 0,0980 & 0,0038 & 0,0213 & 0,0321 & 0,0170 & 0,0321 & 0,0101 & 45 \\
\hline A2 & 97,9241 & 0,5520 & 0,4656 & 0,0941 & 0,0036 & 0,0231 & 0,0000 & 0,0177 & 0,0347 & 0,0085 & 39 \\
\hline Bt 1 & 98,4223 & 0,5405 & 0,4721 & 0,0936 & 0,0018 & 0,0223 & 0,0000 & 0,0184 & 0,0412 & 0,0080 & 48 \\
\hline $\mathrm{Bt} 2$ & 98,5573 & 0,5539 & 0,4972 & 0,0957 & 0,0017 & 0,0235 & 0,0000 & 0,0169 & 0,0266 & 0,0091 & 45 \\
\hline Bt3 & 98,2944 & 0,6461 & 0,6056 & 0,1076 & 0,0016 & 0,0296 & 0,0000 & 0,0190 & 0,0369 & 0,0116 & 64 \\
\hline $\mathrm{Cc}$ & 82,7324 & 5,5399 & 8,6742 & 0,2832 & 0,0031 & 0,0397 & 0,0057 & 0,1068 & 0,1644 & 0,0737 & 69 \\
\hline
\end{tabular}




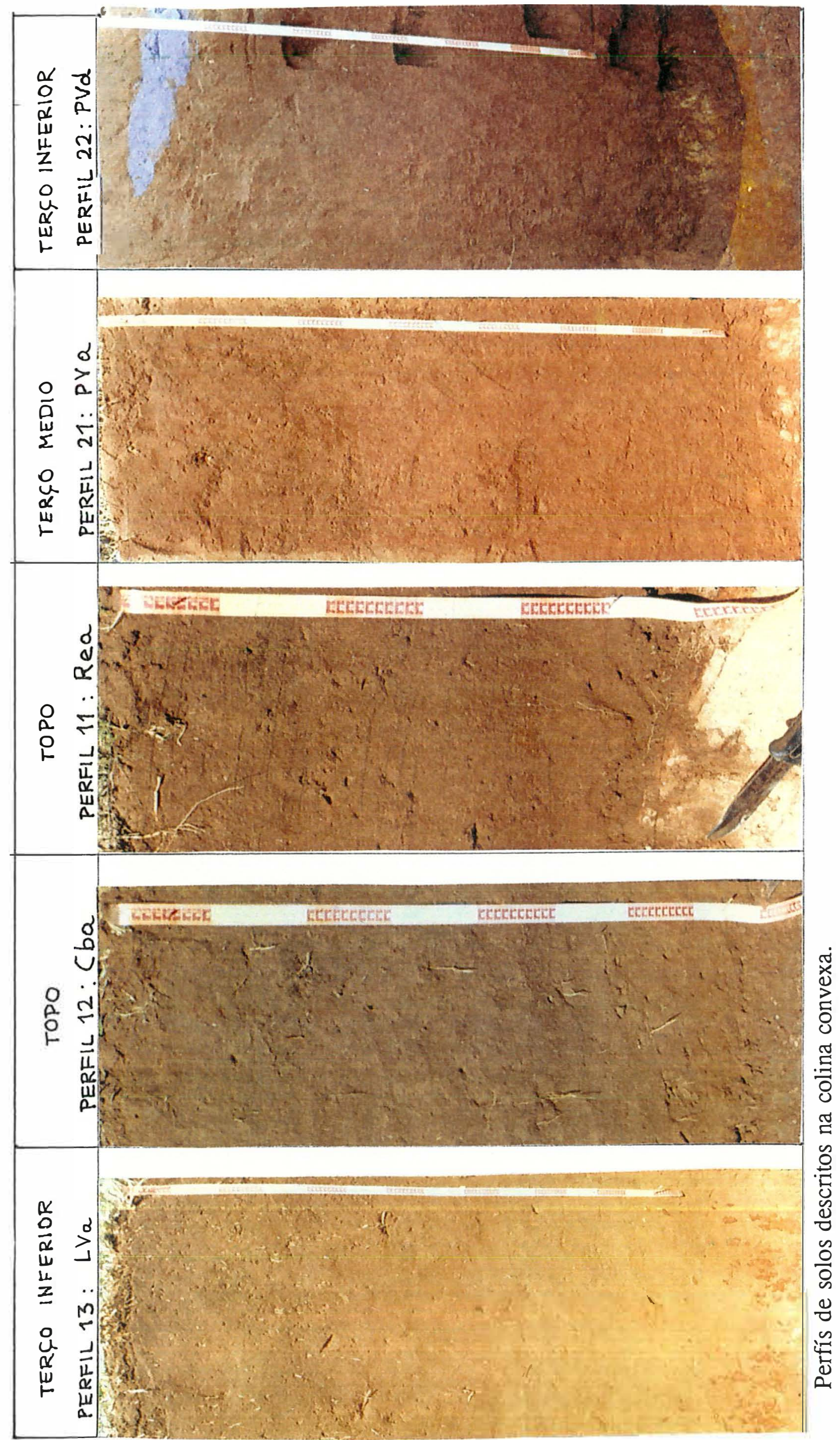




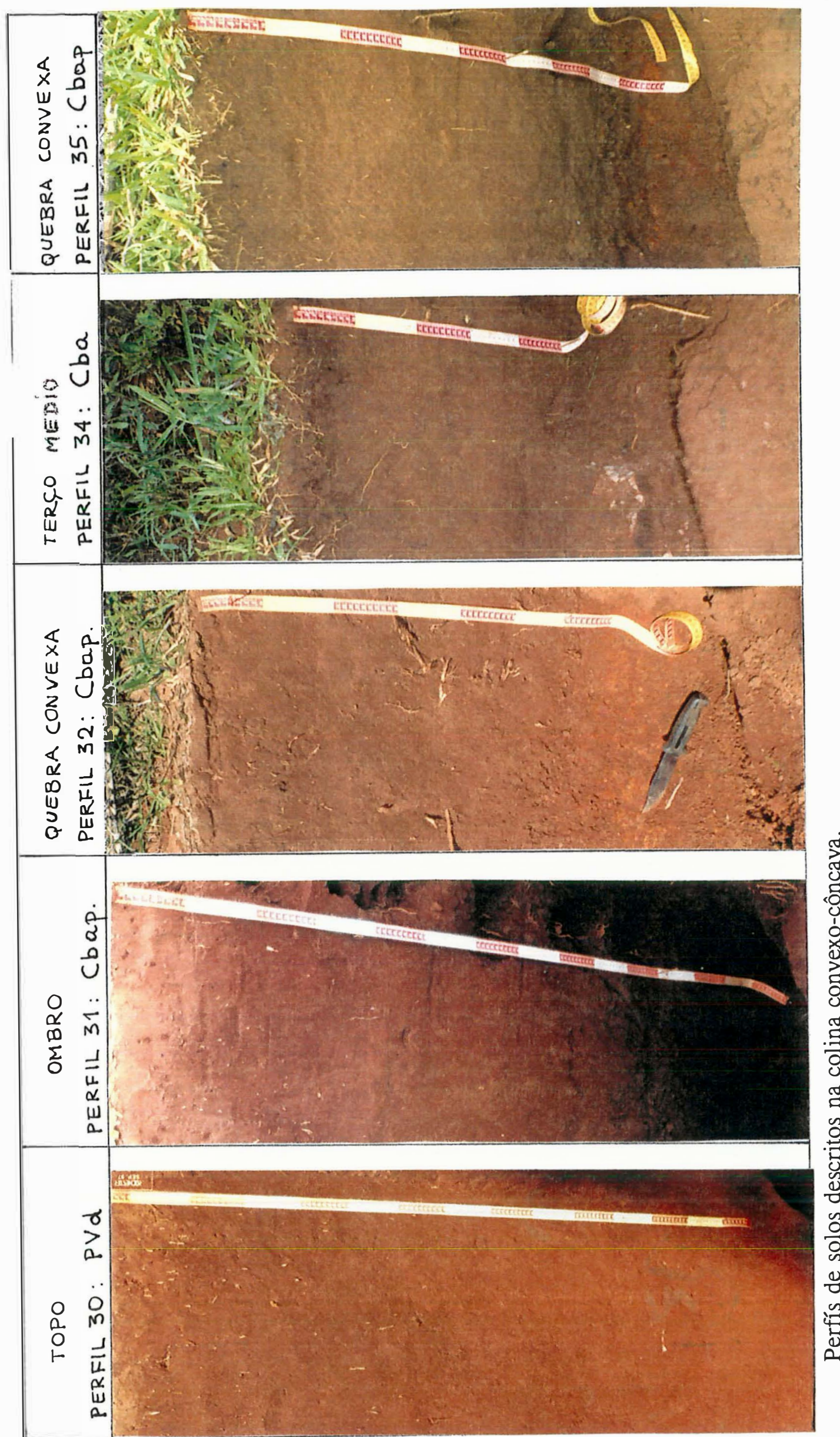




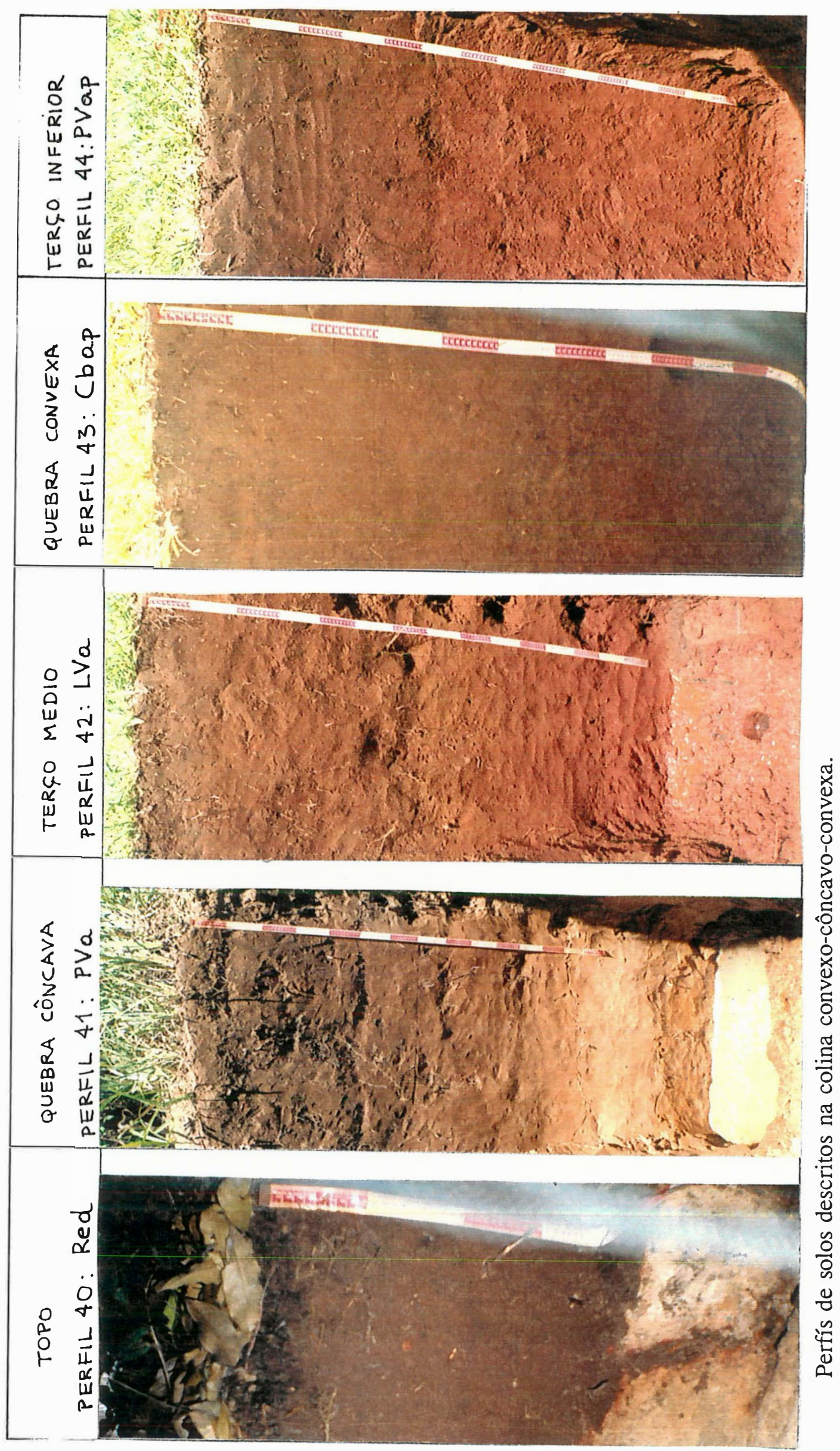

